\title{
\#USGS
}

\section{U.S. Geological Survey Energy and Wildlife Research Annual Report for 2019}

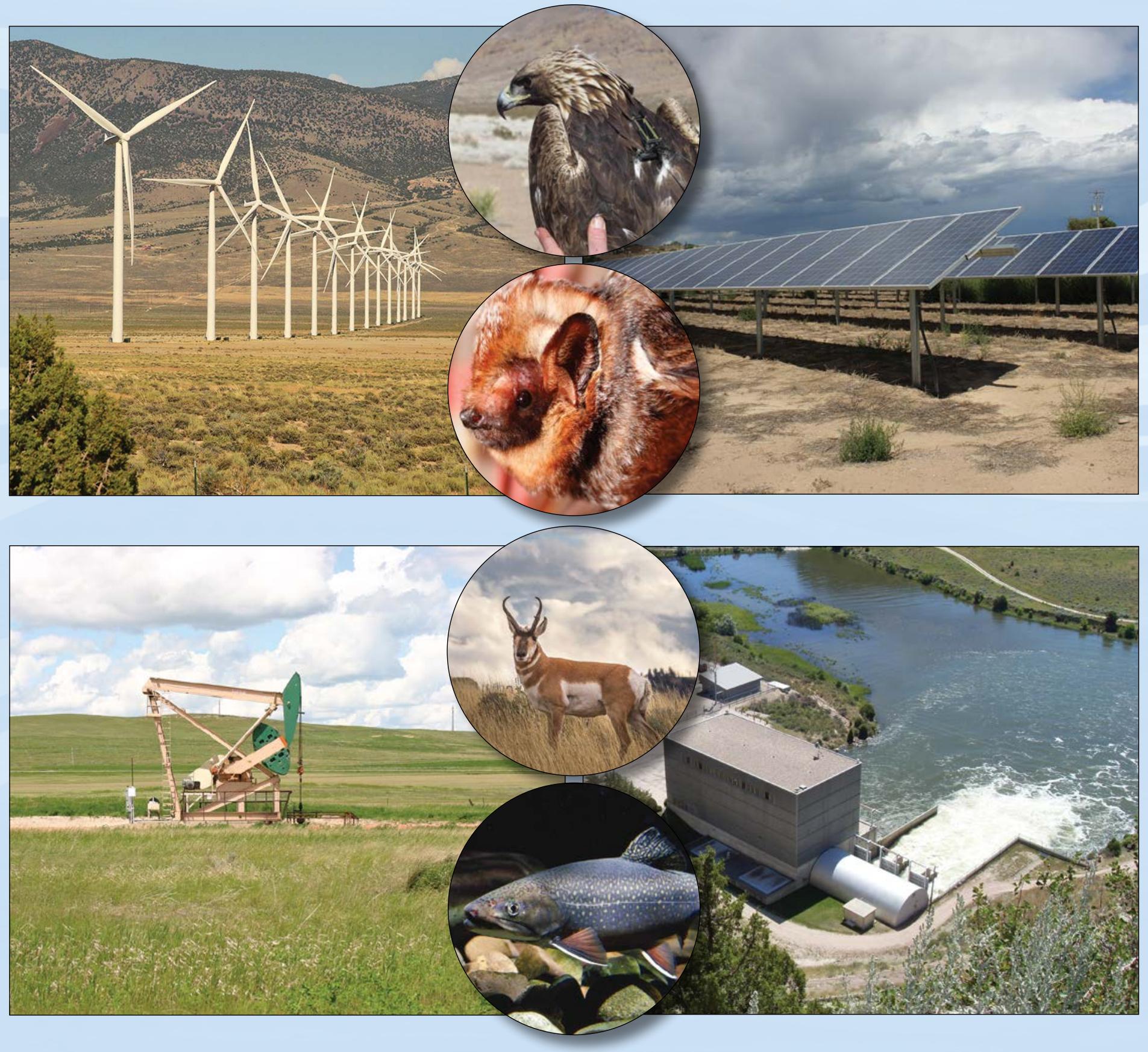

Circular 1458

\section{U.S. Department of the Interior}

U.S. Geological Survey 
Cover. Top left: Wind energy facility in White Pine County, Nevada (photograph by Alan Cressler, U.S. Geological Survey [USGS]). Top right: Solar energy facility in Colorado (photograph by Jessica Robertson, USGS). Bottom left: Oil production in Montana (photograph by Lawrence Igl, USGS). Bottom right: Hydroelectric power plant in Glendo State Park, Wyoming (photograph from Wikimedia, Creative Commons 3.0). Center from top to bottom: Golden eagle fitted with Global Positioning System backpack (photograph by USGS); Hawaiian hoary bat (photograph by Frank Bonaccorso, USGS); Pronghorn (photograph by National Park Service); Brook trout (photograph by U.S. Fish and Wildlife Service). 


\section{U.S. Geological Survey Energy and Wildlife Research Annual Report for 2019}

Edited by Mona Khalil

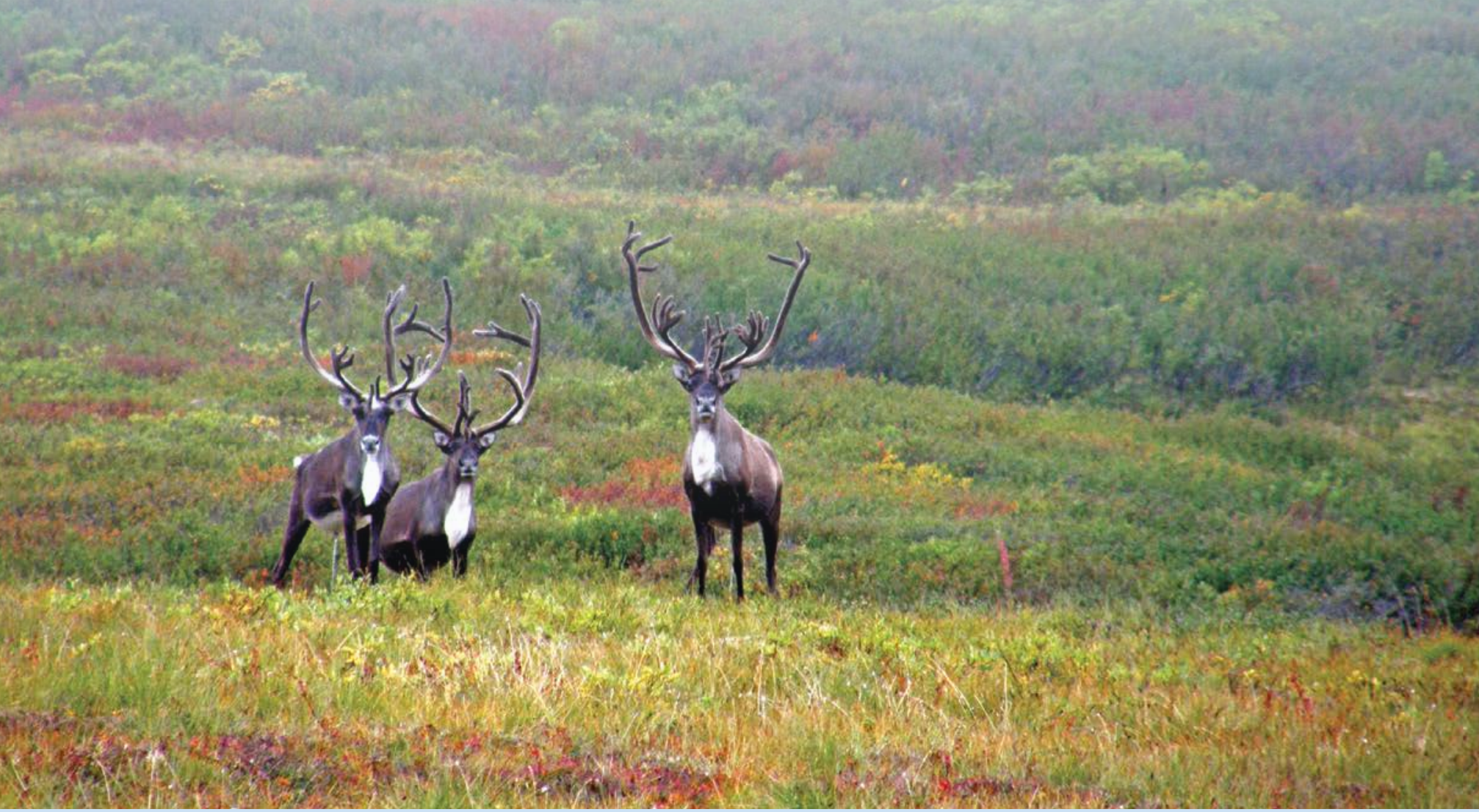

Three caribou standing in the tundra in Alaska. Photograph by Andrew Ramey, U.S. Geological Survey.

Circular 1458

U.S. Department of the Interior

U.S. Geological Survey 


\title{
U.S. Department of the Interior \\ DAVID BERNHARDT, Secretary
}

\author{
U.S. Geological Survey \\ James F. Reilly II, Director
}

U.S. Geological Survey, Reston, Virginia: 2019

For more information on the USGS - the Federal source for science about the Earth, its natural and living resources, natural hazards, and the environment-visit https://www.usgs.gov or call 1-888-ASK-USGS.

For an overview of USGS information products, including maps, imagery, and publications,

visit https://store.usgs.gov.

Any use of trade, firm, or product names is for descriptive purposes only and does not imply endorsement by the U.S. Government.

Although this information product, for the most part, is in the public domain, it also may contain copyrighted materials as noted in the text. Permission to reproduce copyrighted items must be secured from the copyright owner.

Suggested citation:

Khalil, M., ed., 2019, U.S. Geological Survey energy and wildlife research annual report for 2019: U.S. Geological Survey Circular 1458, 108 p., https://doi.org/10.3133/cir1458.

ISSN 1067-084X (print)

ISSN 2330-5703 (online)

ISBN 978-1-4113-4335-1 


\section{Contents}

Science to Understand Risks, Measure Impacts, and Inform Solutions...........................................

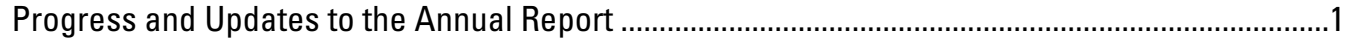

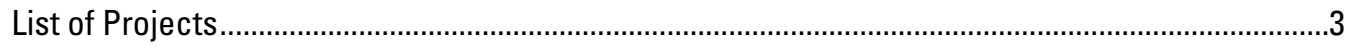

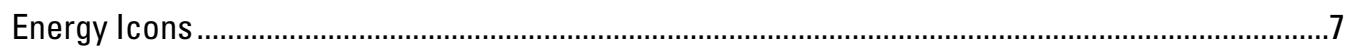

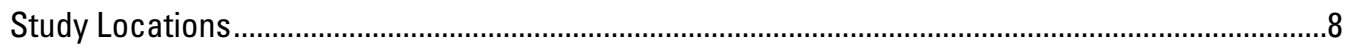

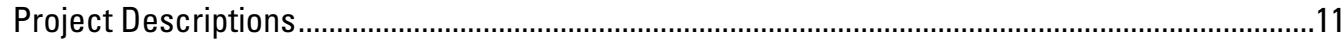

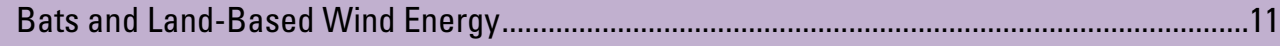

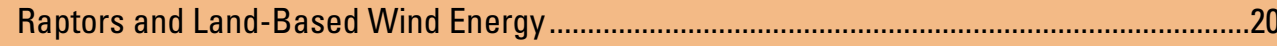

Grassland Birds and Waterbirds and Land-Based Energy ...................................................26

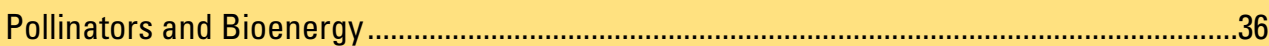

Reptiles and Amphibians and Land-Based Energy ……........................................................

Big Game and Other Terrestrial Mammals and Land-Based Energy .....................................4

Coastal and Marine Birds and Offshore Energy .................................................................... 48

Marine Animals and Offshore Energy …………………....................................................58

Fish and Other Aquatic Species and Hydropower ............................................................66

Terrestrial and Aquatic Habitats and Ecosystem Functions......................................................74

Conservation and Energy Development Planning and Management Tools.............................84

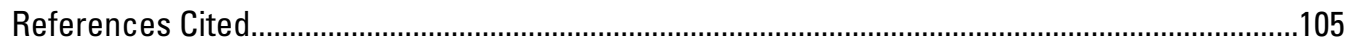

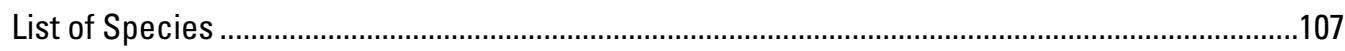




\section{Abbreviations}

\begin{tabular}{|c|c|}
\hline AWEA & American Wind Energy Association \\
\hline $\mathrm{BCl}$ & Bat Conservation International \\
\hline BLM & Bureau of Land Management \\
\hline BOEM & Bureau of Ocean Energy Management \\
\hline BSEE & Bureau of Safety and Environmental Enforcement \\
\hline DEEP SEARCH & Deep-Sea Exploration to Advance Research on Coral/Canyon/Cold Seep Habitats \\
\hline DNA & deoxyribonucleic acid \\
\hline DOE & U.S. Department of Energy \\
\hline DOI & U.S. Department of the Interior \\
\hline DWH & Deepwater Horizon \\
\hline eDNA & Environmental DNA \\
\hline EPA & U.S. Environmental Protection Agency \\
\hline FSC & floating surface collector \\
\hline GIS & geographic information system \\
\hline GOM & Gulf of Mexico \\
\hline GoMMAPPS & Gulf of Mexico Marine Assessment Program for Protected Species \\
\hline GPS & Global Positioning System \\
\hline GPS-GSM & Global Positioning System-Global System for Mobile communications \\
\hline MFTB & Mexican free-tailed bats \\
\hline MHI & main Hawaiian Islands \\
\hline NABat & North American Bat Monitoring Program \\
\hline NEXRAD & Next Generation Weather Radar \\
\hline NGO & nongovernmental organization \\
\hline NMFS & National Marine Fisheries Service \\
\hline NOAA & National Oceanic and Atmospheric Administration \\
\hline NOPP & National Oceanographic Partnership Program \\
\hline NPR-A & National Petroleum Reserve-Alaska \\
\hline NPS & National Park Service \\
\hline OCS & Outer Continental Shelf \\
\hline OER & Office of Exploration and Research \\
\hline PPR & Prairie Pothole Region \\
\hline RAMPS & Restoration Assessment and Monitoring Program for the Southwest \\
\hline SDM & structured decision making \\
\hline UOG & unconventional oil and gas \\
\hline USACE & U.S. Army Corps of Engineers \\
\hline USDA & U.S. Department of Agriculture \\
\hline USFWS & U.S. Fish and Wildlife Service \\
\hline USGS & U.S. Geological Survey \\
\hline UV & ultraviolet \\
\hline WEC & wave energy conversion \\
\hline WLCl & Wyoming Landscape Conservation Initiative \\
\hline WNS & white-nose syndrome \\
\hline
\end{tabular}




\title{
U.S. Geological Survey Energy and Wildlife Research Annual Report for 2019
}

\author{
Edited by Mona Khalil
}

\section{Science to Understand Risks, Measure Impacts, and Inform Solutions}

Access to affordable and reliable energy remains a critical need for people and the economy. To satisfy society's demand for energy, the United States is expanding access to vast natural resources to produce electricity as well as petroleum and natural gas products. Oil and gas production and wind and solar energy generation have shown consistent growth over the last 15 years. Currently, more than 59,000 wind turbines are contributing to power grids in 41 States, Guam, and Puerto Rico (American Wind Energy Association, 2019; Hoen and others, 2019), and more than 9,200 ground-mounted solar projects with a capacity of 1 megawatt and above are in operation, under construction, or under development (Solar Energy Industries Association, 2019).

Development of our Nation's vast energy resources, however, often conflicts directly with the equally vast fish and wildlife resources, which contribute billions of dollars to the economy through harvest, recreation, and services to humans and agriculture. The effects of energy development on living resources include fragmentation of populations, degradation or loss of habitat, and direct mortality of birds, bats, fish, and other wildlife interacting with energy generation facilities. Thus, an expanding energy infrastructure results in new requirements for land and ocean conversion for project siting and operational decisions to minimize risk to fish and wildlife resources.

The U.S. Geological Survey (USGS) is a bureau within the U.S. Department of the Interior (DOI). The USGS mission is to provide reliable scientific information to describe and understand the Earth; minimize loss of life and property from natural disasters; manage water, biological, energy, and mineral resources; and enhance and protect our quality of life. USGS scientists partner with more than 150 Federal, State, and local government agencies; Tribal nations; academic institutions; and nongovernmental organizations (NGOs) to deliver timely and relevant information on pressing resource management issues. This information helps decision makers balance development with stewardship of the Nation's fish and wildlife heritage. USGS studies related to energy development focus on delivering information to help resource managers and energy developers avoid, minimize, or mitigate the impacts of energy infrastructure on fish and wildlife. These studies have three primary goals:

1. Understand risks by identifying when, where, and how fish and wildlife share space with energy facilities.

2. Measure direct and indirect impacts to species and habitats.

3. Inform feasible and cost-effective solutions to minimize impacts through technology and management strategies.

\section{Progress and Updates to the Annual Report}

This report summarizes ongoing USGS research projects and publications related to the impacts of energy development on fish and wildlife resources, tools to assess those impacts, and solutions to avoid or minimize risk. These studies are funded through a combination of Congressionally appropriated funds to the USGS and supplemental contributed funds from USGS partners, including other Federal and State resource management agencies.

This year's report features geospatial models and tools for species and habitats that were produced to assist resource managers and the industry in siting new energy development and selecting off-site mitigation areas. Research efforts are applied to oil and gas development activities, where USGS tools can identify areas of lowest conflict between energy development and sensitive resources, such as trust and at-risk species, and provide management solutions that improve the recovery of species and landscapes altered by energy extraction. To address wildlife concerns related to wind energy development, the USGS is working with stakeholders and industry to develop technologies and management solutions to 
maximize wind-facility development and energy production while reducing wildlife fatalities at wind farms. USGS scientists are testing bat deterrent devices and operational management strategies that allow companies to meet guidelines and remain productive. To address emerging wildlife issues related to utility-scale solar energy, the USGS assists land and wildlife managers, industry, and other stakeholders by identifying the causes of negative effects to animals and the areas where impacts can be minimized. Finally, to improve aquatic ecosystems and species recovery, USGS scientists are designing next-generation fish passage devices for hydropower dams that can replace those reaching the end of their lifespans, improve migratory fish passage, and reduce spread of invasive species.

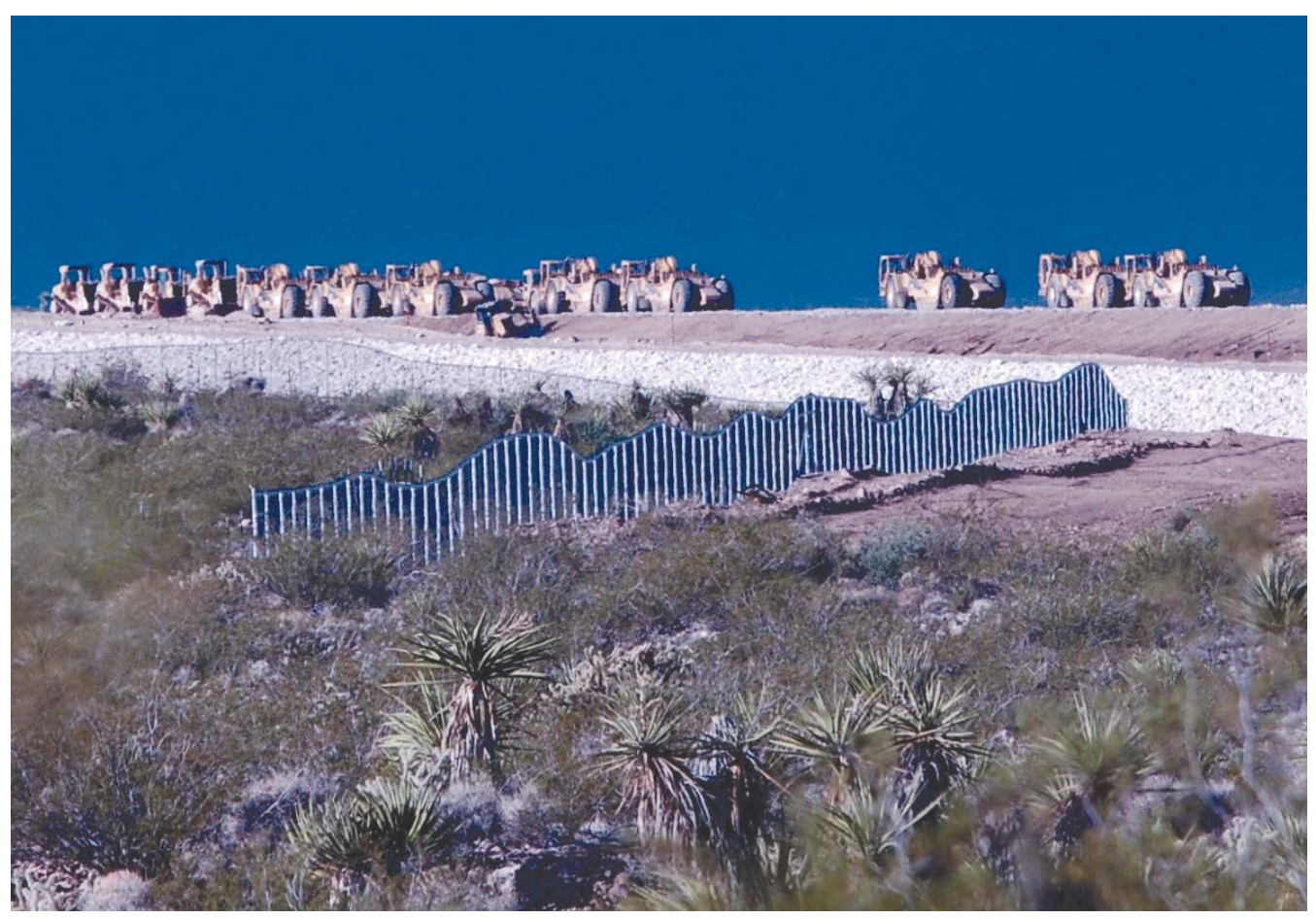

Renewable energy development in the desert Southwest presents challenges to the threatened desert tortoise. New research quantifies the risks of such activities. Photograph by Todd C. Esque, U.S. Geological Survey. 


\section{List of Projects}

Regulatory and management issues associated with energy development are often focused on the impacts on legally protected species and (or) other species and habitats of concern. USGS science efforts described in this report are organized by species or groups of species, habitats, and other topics considered most relevant to the U.S. Fish and Wildlife Service (USFWS), Bureau of Land Management (BLM), Bureau of Ocean Energy Management (BOEM), Bureau of Reclamation, National Park Service (NPS), and other Federal and State agencies responsible for permitting energy projects, conserving or managing species and habitats, and monitoring operations of renewable or conventional energy facilities.

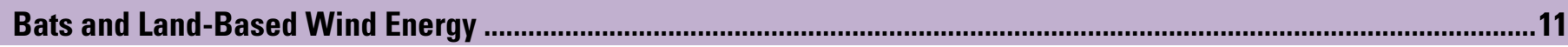

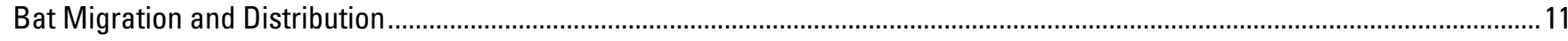

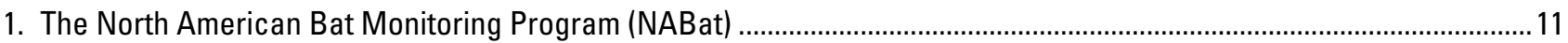

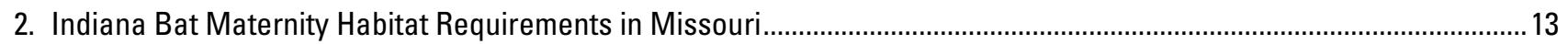

3. Bat Conservation and Recovery in Nebraska and Wyoming ........................................................................................... 13

4. Pre- and Post-Hibernation and Migratory Activity of Bats in the Central Appalachians .................................................13

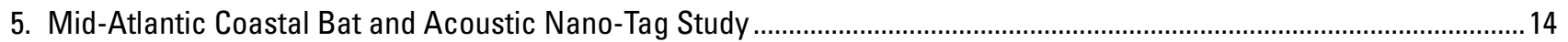

6. Post-White-Nose Syndrome Assessment of Bat Distribution in the Mid-Atlantic and Northeast..................................... 14

7. Modeling Foraging Habitat Suitability of the Hawaiian Hoary Bat .................................................................................. 15

8. Bat Monitoring in the North Coast and Cascades Network of National Parks ................................................................... 16

9. Distribution of Bat Species in Relation to Habitat Characteristics in Marin County, California ........................................16

Bat Behavior Near Wind Turbines and Strategies to Minimize Adverse Impacts .................................................................... 16

10. Using Genomics to Determine History and Trends of a Bat Population Susceptible to Wind Turbines ..............................16

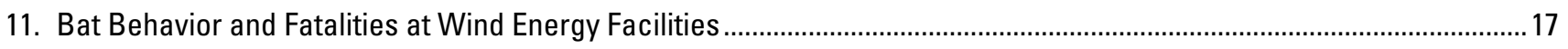

12. Ultraviolet Illumination as a Means of Reducing Bat Activity and Risk at Wind Turbines................................................18

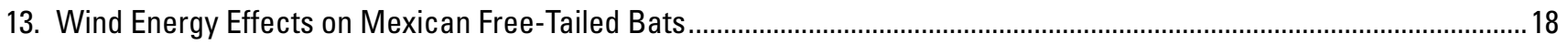

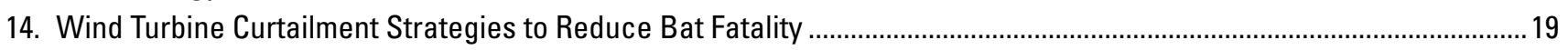

15. Comparing the Effectiveness of Acoustic Deterrents to Operational Curtailment in Reducing Bat Fatality.....................19

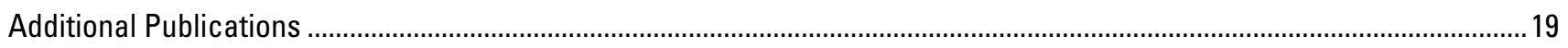

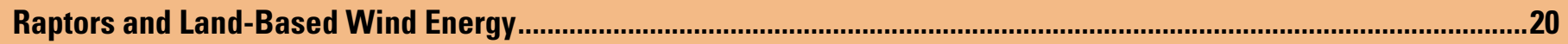

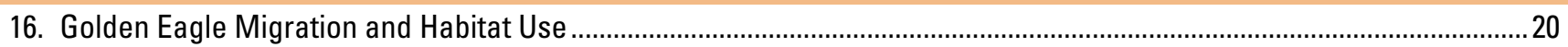

17. Golden Eagle Movement and Conservation in Coastal Southern California ....................................................................21

18. Population Demography of Golden Eagles Near Altamont Pass, California ........................................................................22

19. Tracking Bald Eagles Near Wind Energy Facilities in the Central Great Plains .............................................................. 23

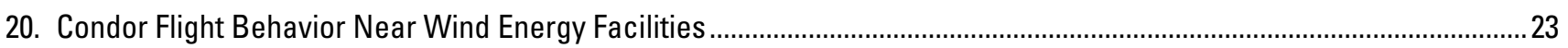

21. Interactions of Juvenile Swainson's Hawks With Wind Energy Facilities During Dispersal and Migration ......................24

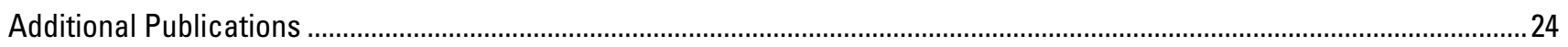

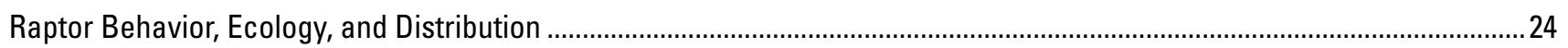

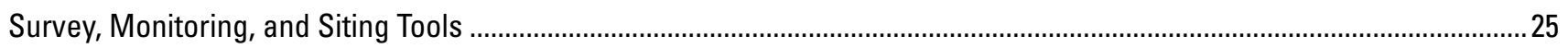

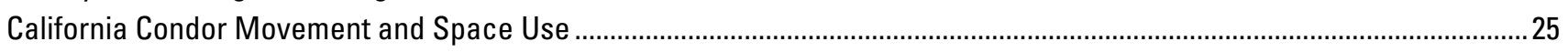

Grassland Birds and Waterbirds and Land-Based Energy ..............................................................................................26

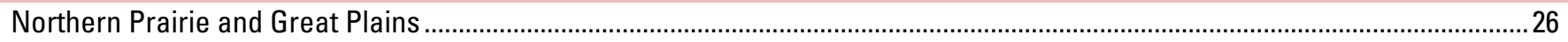

22. Prairie Grouse Lek Dynamics in Landscapes Near Wind Energy Facilities in North Dakota and South Dakota...............26

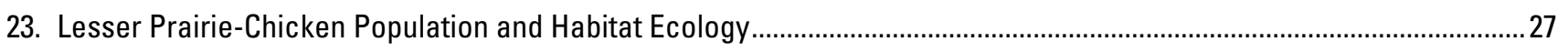

24. Estimating Offsets for Avian Displacement Effects of Anthropogenic Activities ...........................................................28

25. Assessing Potential Disturbance and Threats Posed by Energy Development for Aransas-Wood Buffalo

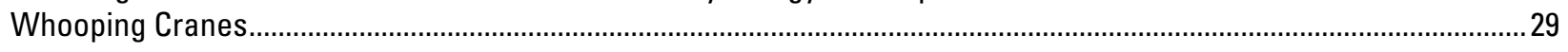

26. Population Dynamics of Piping Plovers and Least Terns in Response to Missouri River Management............................29 
Intermountain West

27. Potential Impacts of Future Oil and Gas Development and Climate Change on Greater Sage-Grouse in Southwest Wyoming. . .30

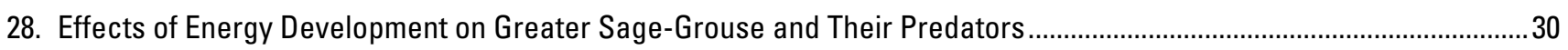

29. Implications of Anthropogenic Activities on Greater Sage-Grouse Populations in Nevada ...........................................32

30. Influence of Energy Development and Climatic Variability on Sagebrush Songbirds.......................................................32

Alaska

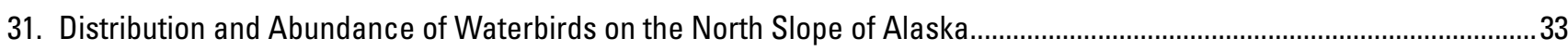

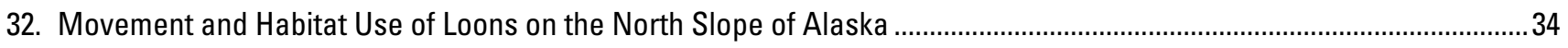

33. Breeding Territory Retention in Pacific and Yellow-Billed Loons in the National Petroleum Reserve-Alaska ..................34

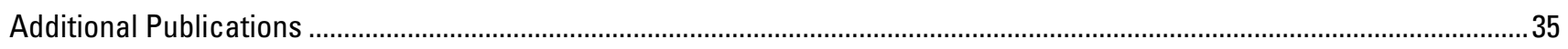

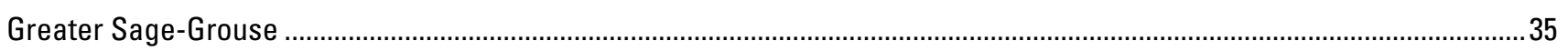

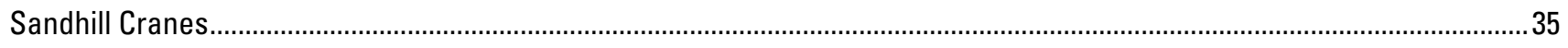

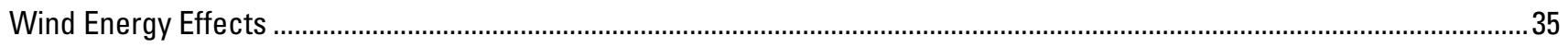

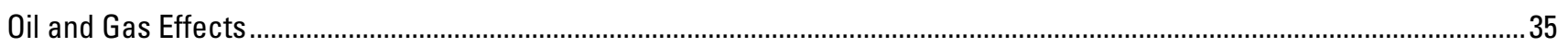

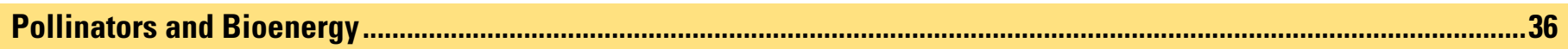

34. Using Drones and Citizen Science to Map the Distribution of Milkweed for Monarch Butterflies ................................36

35. Impact of Biofuel Crop Production on Pollinators in the Northern Great Plains .................................................................

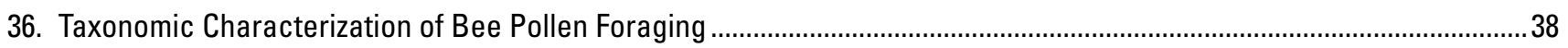

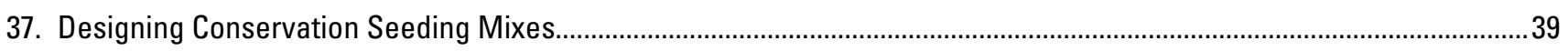

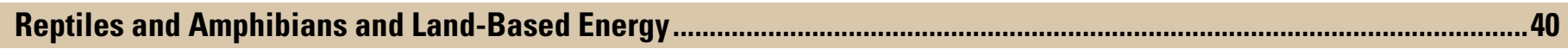

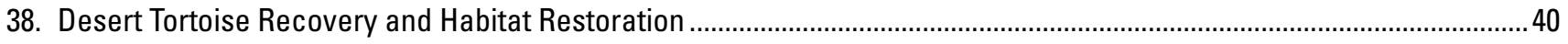

39. Distribution and Habitat Associations of Narrowly Endemic Great Basin Toads............................................................... 41

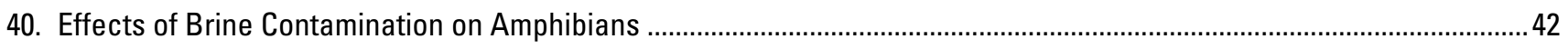

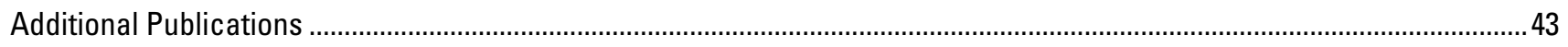

Desert Tortoise

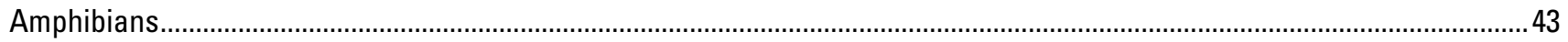

Big Game and Other Terrestrial Mammals and Land-Based Energy.............................................................................44

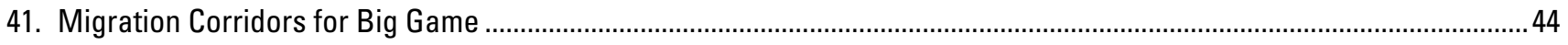

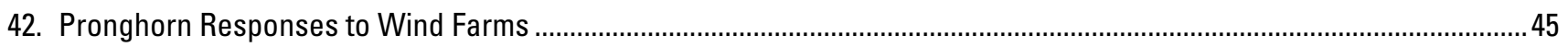

43. Influence of Oil Development on the Behavior of Barren-Ground Caribou .....................................................................4

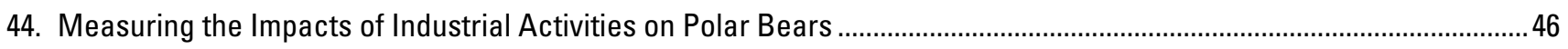

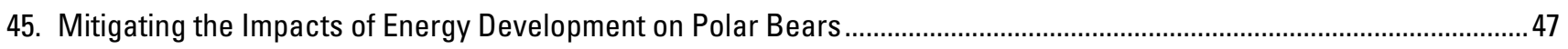

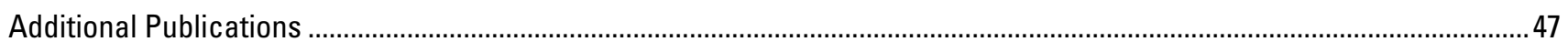

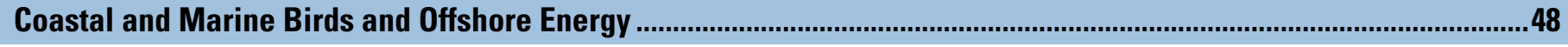

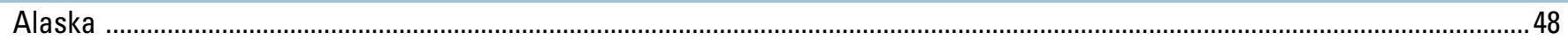

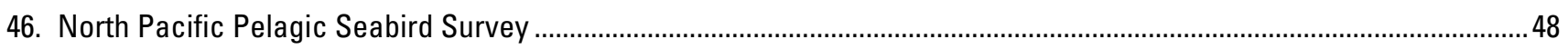

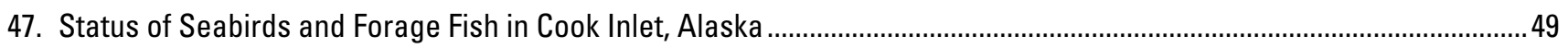

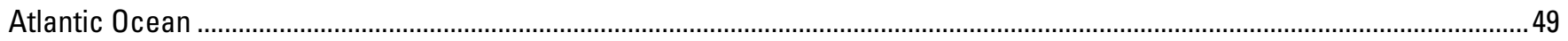

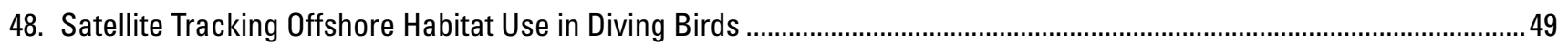

49. External GPS-GSM Transmitters for Tracking Seabirds ........................................................................................... 50

50. Potential Impacts of Offshore Wind Energy Projects on Endangered Roseate Terns.......................................................50

51. Spatial and Foraging Ecology of Brown Pelicans in the South Atlantic Bight.................................................................. 51

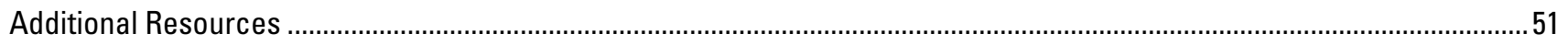

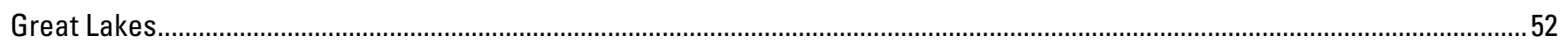

52. Distribution, Abundance, and Movement of Waterbirds on Lake Michigan ...................................................................52 
Gulf of Mexico 52

53. Distribution of Landbirds During Migratory Stopover in the Gulf of Mexico Region ..........................................................52

54. Spatial and Reproductive Ecology of Brown Pelicans in the Gulf of Mexico …….........................................................53

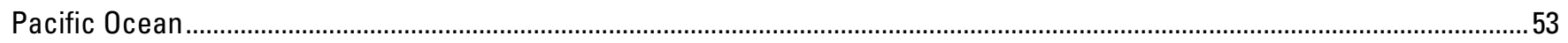

55. Pacific Marine Bird and Mammal Research and Monitoring Programs ……...............................................................53

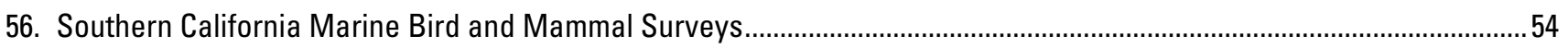

57. Predictive Modeling of Marine Bird Distributions on the Pacific Outer Continental Shelf .............................................55

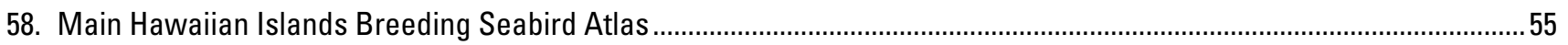

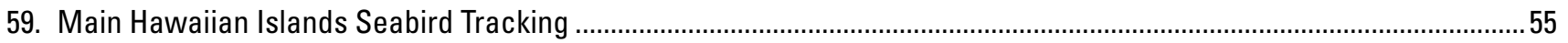

60. Seabird and Marine Mammal Aerial Surveys Off Northern California, Oregon, and Washington...................................56

61. Seabird Vulnerability Assessment for Renewable Energy Projects on the Pacific Outer Continental Shelf .....................57

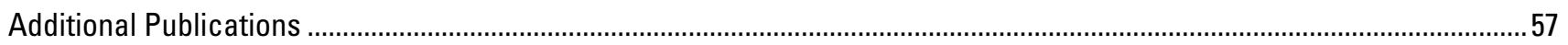

Marine Animals and Offshore Energy

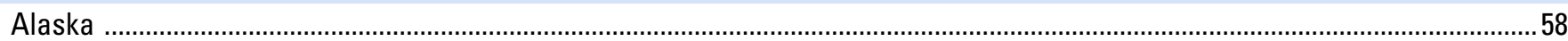

62. Gulf Watch Alaska Program for Quantifying Coastal Marine Ecosystem Change ............................................................58

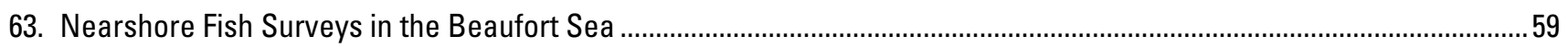

64. Quantifying the Response of Pacific Walrus to Ocean Noise in the Arctic .................................................................60

65. Distribution and Abundance of Pacific Walrus in Relation to Offshore Development in Alaska.......................................60

Atlantic Ocean and Gulf of Mexico

66. Florida Manatee Movement and Habitat Use in the Northern Gulf of Mexic 0 ...............................................................61

67. Science to Support the Transition of Florida Manatees to Natural Warm-Water Sites......................................................62

68. Gulf of Mexico Marine Assessment Program for Protected Species ................................................................................62

69. Sea Turtle Movement and Habitat Use in the Northern Gulf of Mexico ……...................................................................62

70. Deep-Sea Exploration to Inform Potential Offshore Energy and Minerals Development................................................63

71. Changes to Infaunal Communities Associated With Deep-Sea Coral and Their Potential Recovery From the

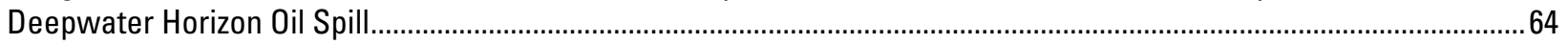

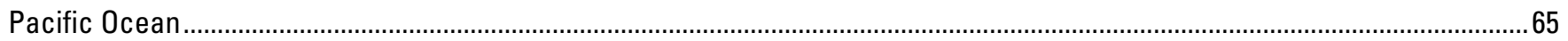

72. Benthic Assemblages of Mega Epifauna on the Oregon Continental Margin .............................................................65

73. Predicting the Effects of Wave Energy Facilities on Nearshore Ecosystems.................................................................65

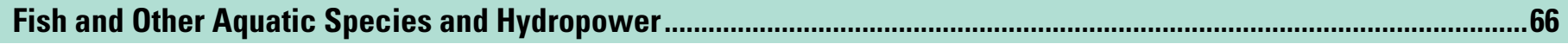

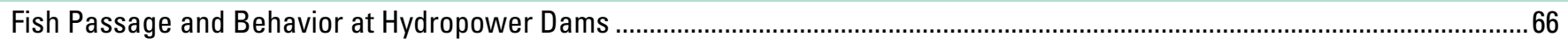

74. Full-Scale Development and Evaluations of Fish Passage Structures and Fish Behavior .................................................66

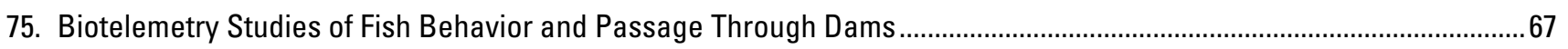

76. Downstream Fish Passage and Survival Through Dams ...............................................................................................

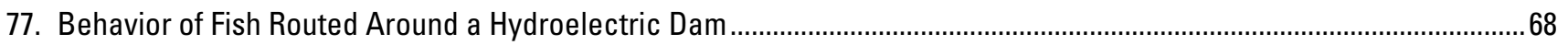

78. Developing Selective Fish Passage to Block Invasive Sea Lamprey ................................................................................

Hydropower Effects on Fish and Aquatic Resources..........................................................................................................69

79. Evaluating Flow Management as a Strategy to Recover Endangered Pallid Sturgeon in the Upper Missouri River ........69

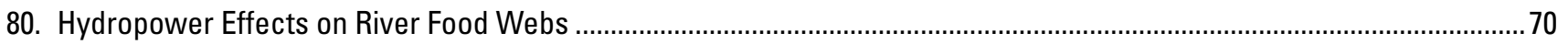

81. Effects of Dam Operations on Endangered and Introduced Fish Populations....................................................................

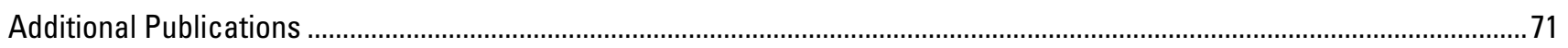

Optimizing Dam Operations and Management............................................................................................................... 72

82. Adaptive Management of Flows From R.L. Harris Dam on the Tallapoosa River, Alabama...............................................72

83. Missouri River Emergent Sandbar Habitat Classification ............................................................................................... 72

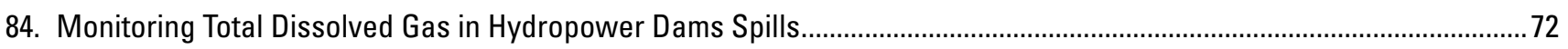

85. Aquatic Invasive Species Control Efforts and Dam Operations ....................................................................................73

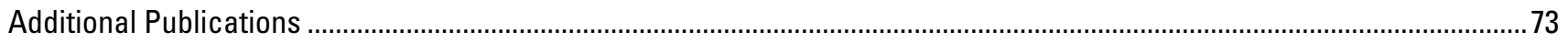




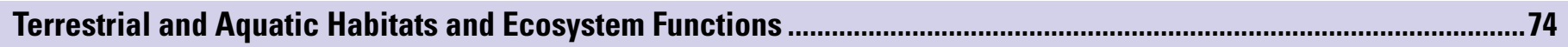

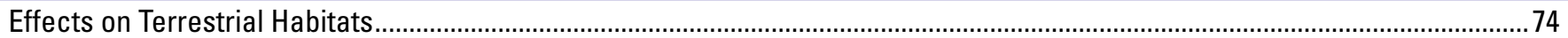

86. Geographic Context in Wind Energy Land Transformation ............................................................................................

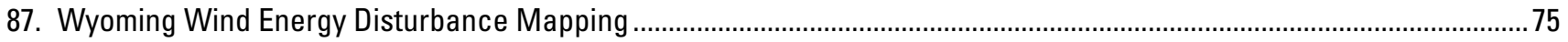

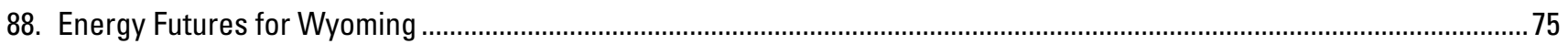

89. Aeolian Dust Associated With Oil and Gas Infrastructure in Sagebrush Ecosystems .....................................................76

90. Potential Effects of Uranium Mining in the Grand Canyon................................................................................................

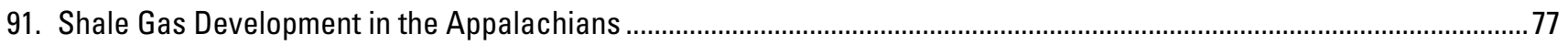

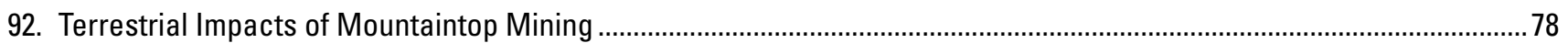

93. Ecological Effects of Brine Contamination in the Prairie Pothole Region …….................................................................

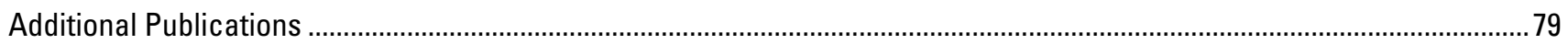

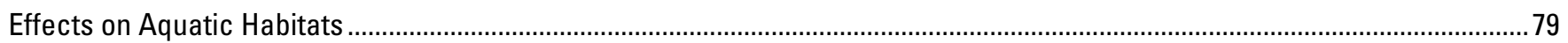

94. Effects of Acid Deposition From Energy Production on Fish and Other Aquatic Species ................................................79

95. Effects of Water Stress From Hydraulic Fracturing on Aquatic Biodiversity and Ecosystem Services in Arkansas.........80

96. Potential Toxicity Associated With Produced Waters From Oil and Gas Activity ........................................................... 81

97. Vulnerability of Brook Trout Streams to Shale Gas Development in the Upper Susquehanna River Basin ........................83

Conservation and Energy Development Planning and Management Tools ..................................................................84

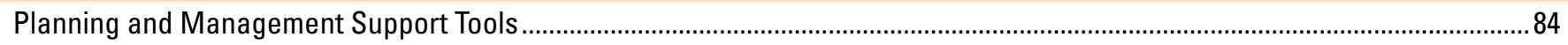

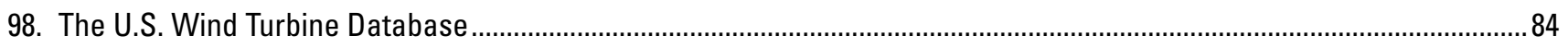

99. Tools for Identifying and Prioritizing Areas Used by Migrating Whooping Cranes...........................................................8 85

100. Mapping Probable Suitable Habitat for Rare Plants in California Deserts.....................................................................86

101. Smart Energy Development in the Sagebrush Ecosystem ............................................................................................ 87

102. Effects of Nest Exposure and Spring Temperatures on Eagle Nestling Survival .............................................................8

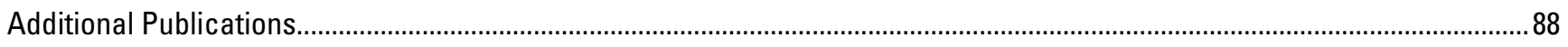

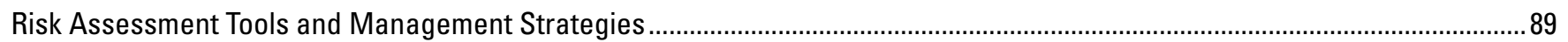

103. Factors Influencing Bird Mortality at Utility-Scale Solar Facilities in California ..................................................................89

104. Assessing Eagle Use Frequency at Wind Energy Facilities .........................................................................................9

105. Tools to Assess Energy Development Impacts on Sensitive Birds and Bats ..................................................................90

106. Quantifying the Potential Effects of Energy Development on Wildlife and Ecosystem Services .....................................90

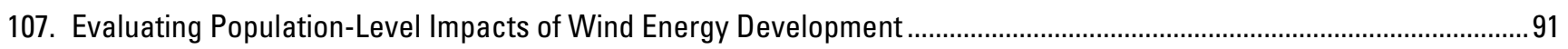

108. Structured Decision Making: Decision Support Frameworks and Tools for Conservation .................................................92

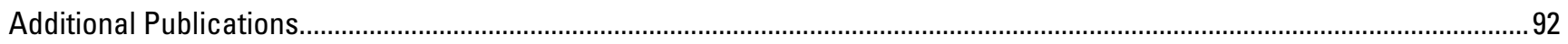

Novel Techniques in Species Detection and Monitoring for Energy Planning and Conservation ............................................92

109. Reducing Bird and Bat Wind Turbine Strikes Using Weather Radar ........................................................................92

110. Automated Detection and Classification of Waterfowl, Seabirds, and Other Wildlife on the Outer Continental Shelf.....93

111. Advancing Wildlife Monitoring Using Weather Surveillance Radar ............................................................................93

112. Monitoring Golden Eagle Nests, Prey, and Behavior Using Cameras............................................................................94

113. eDNA Applications in Freshwater and Ocean Environments ........................................................................................94

114. Using Genomics to Better Understand Habitat Use of the Atlantic Sturgeon ..................................................................95

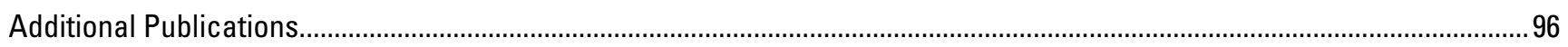

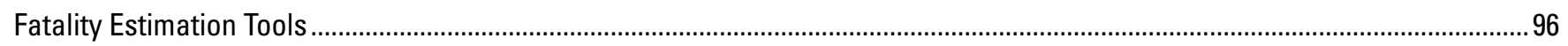

115. Generalized Fatality Estimator (GenEst) Software and User's Guide .............................................................................96

116. Developing a Model to Estimate Eagle-Carcass Density at Wind Energy Facilities............................................................97

117. Advances in Estimating Fatalities From Collisions With Energy Infrastructure ..............................................................97

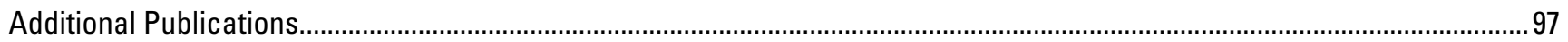


Terrestrial Habitat Restoration Following Energy Development

118. Evaluating Reclamation Success Following Oil and Gas Development............................................................................98

119. Modeling Recovery of Sagebrush Ecosystems Using Remotely Sensed Vegetation Products ........................................ 99

120. Understanding Drought Stress in Sagebrush Ecosystems Associated With Energy Development .................................99

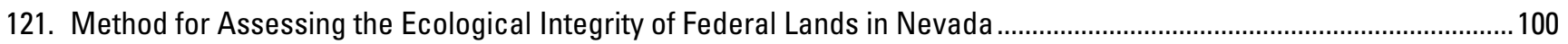

122. Ecological Restoration and Native Plant Development in Hot Desert Systems ................................................................. 100

123. Restoration Assessment and Monitoring Program for the Southwest ....................................................................... 101

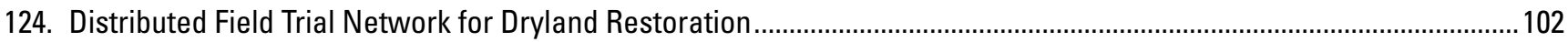

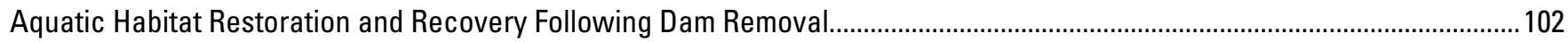

125. Reintroduction of Anadromous Salmonids to Reservoirs Above Hydroelectric Dams ..................................................... 102

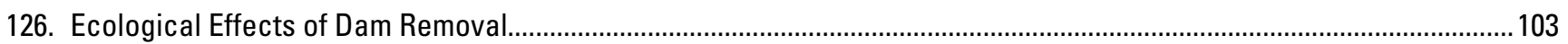

127. A Multiscale Approach to Balance Tradeoffs Among Dam Infrastructure, River Restoration, and Cost........................ 103

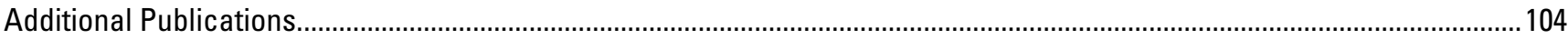

\section{Energy Icons}

Each project is associated with a type of energy production or transmission. Types of energy production or transmission are represented by the following icons:
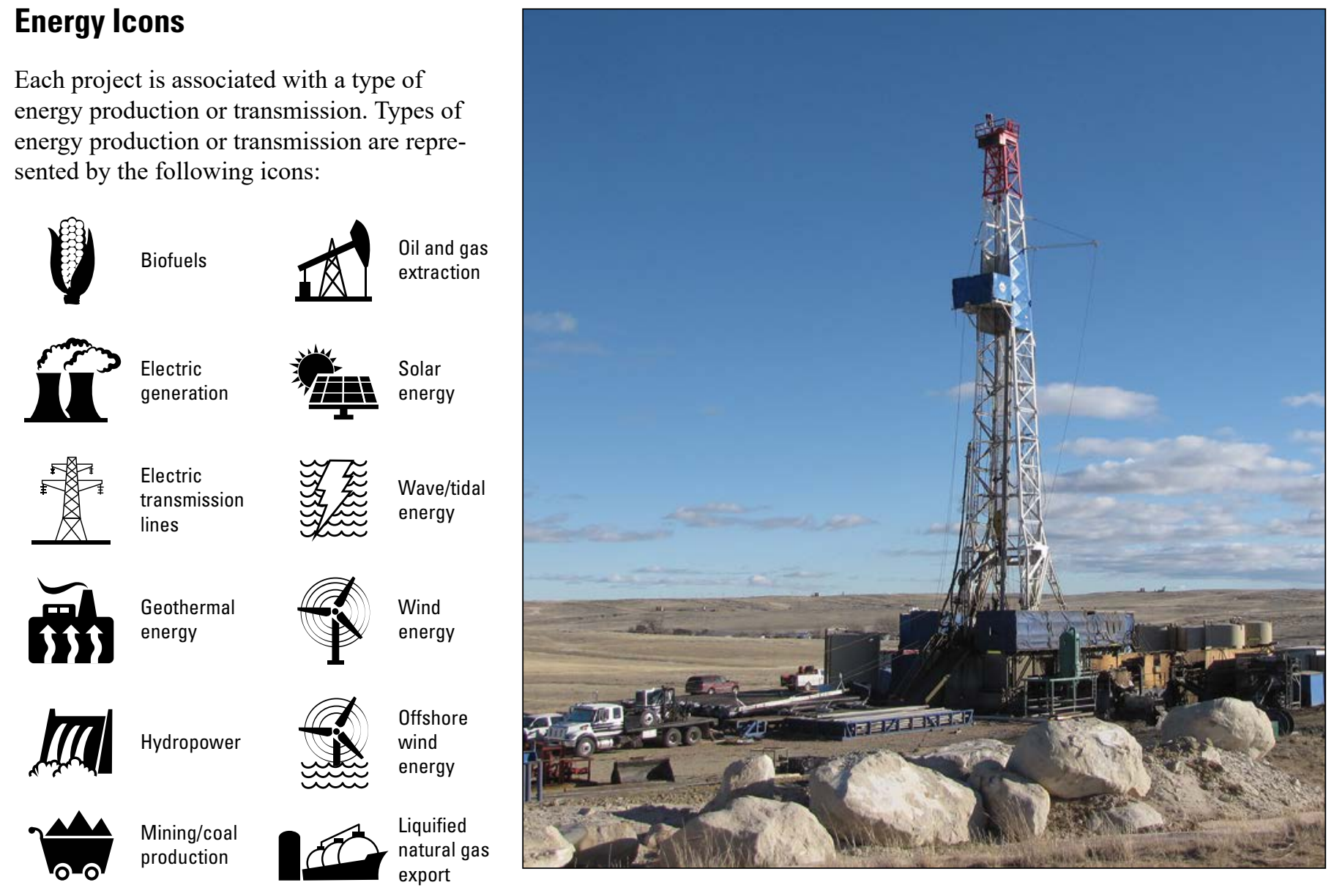

Icons modified from BSGStudio, all-free-download.com. Geothermal energy icon from icons8.com.

This oil rig in Wyoming is an example of long directional drilling, which can limit the amount of surface disturbance due to the rig's long reach. Photograph by Bureau of Land Management. 


\section{Study Locations}

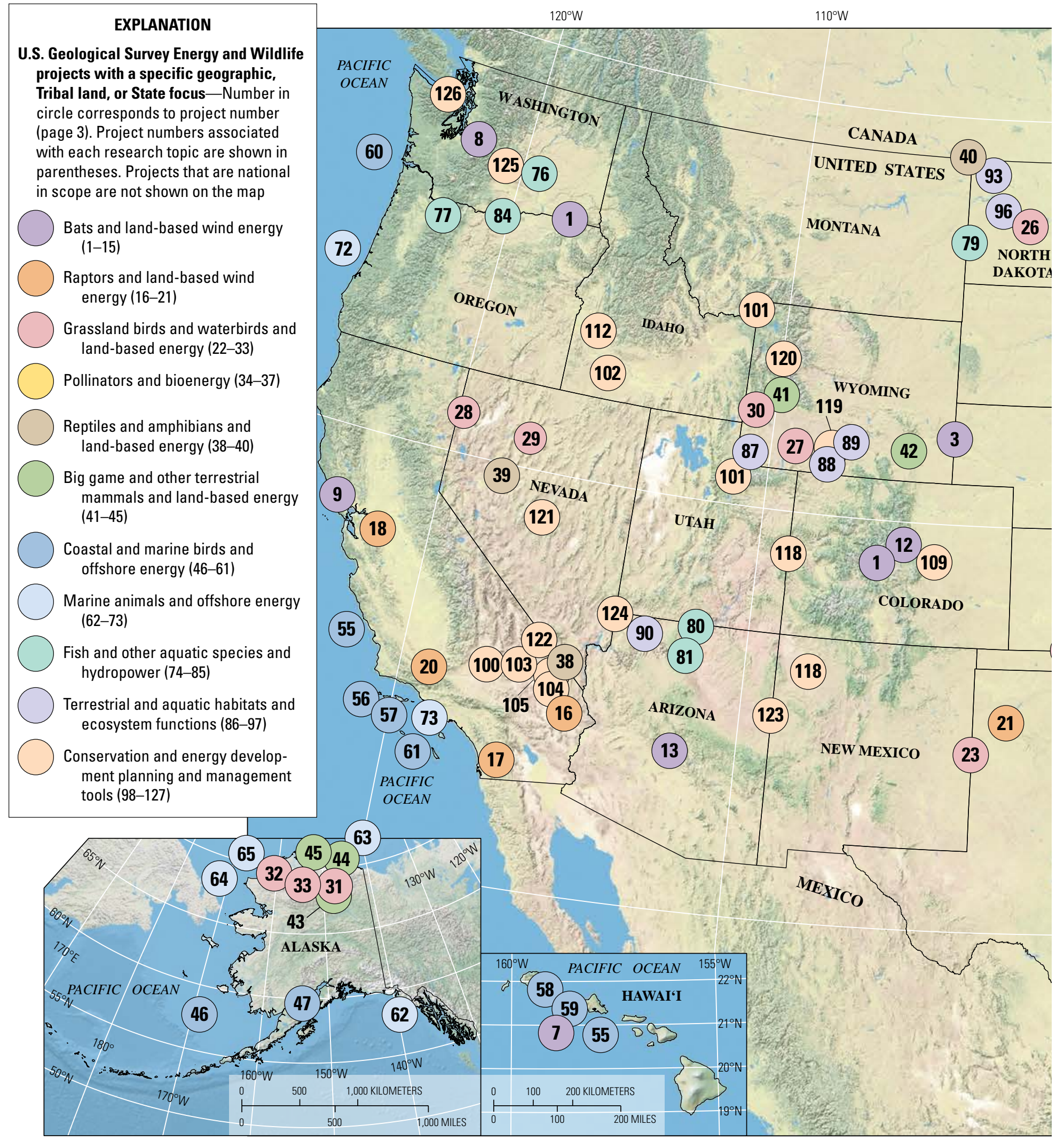

Map image is the intellectual property of Esri and is used herein under license. Copyright (C) 2014 Esri and its licensors. All rights reserved. Universal Transverse Mercator projection, zone 14 


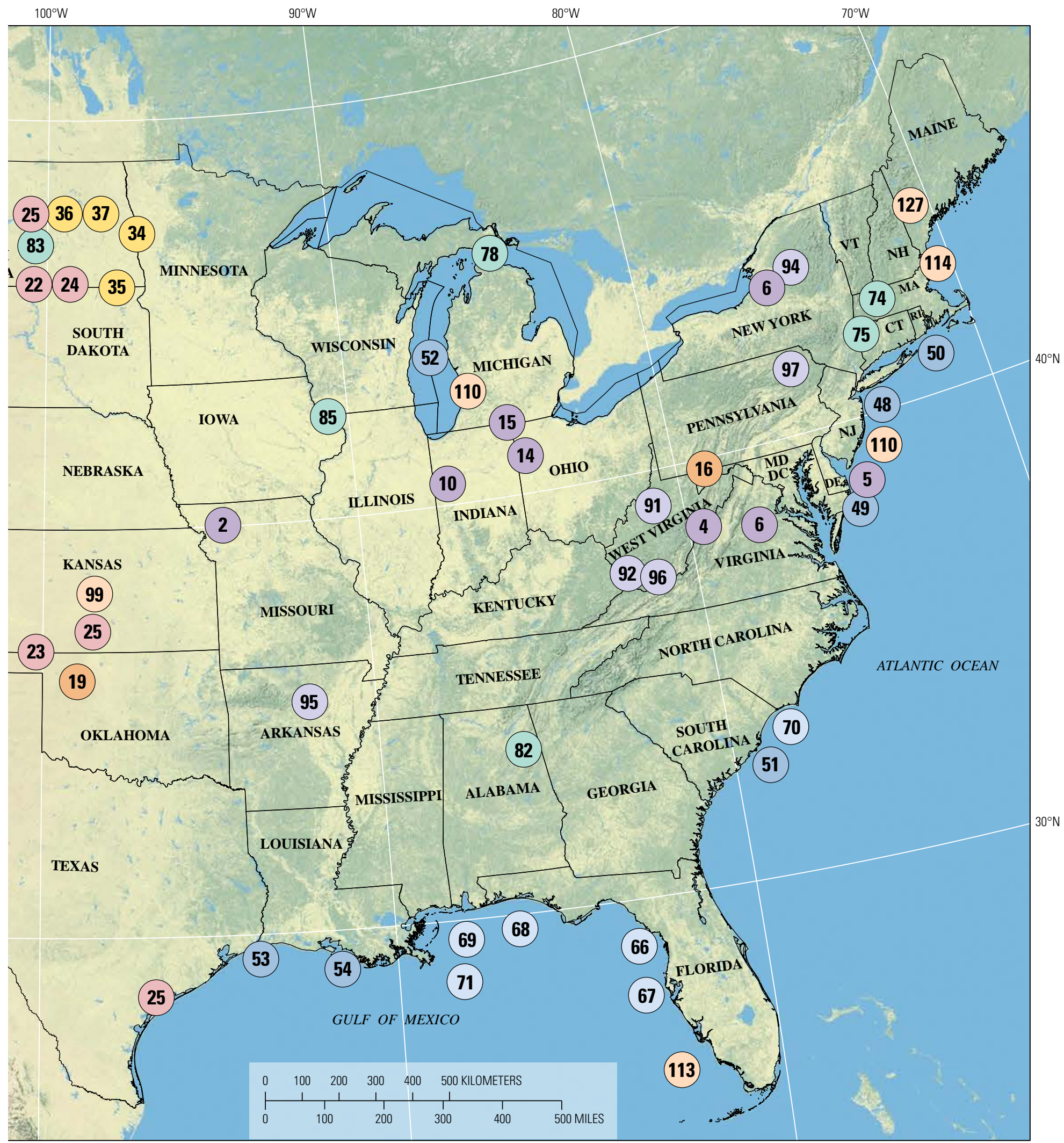




\section{Project Descriptions}

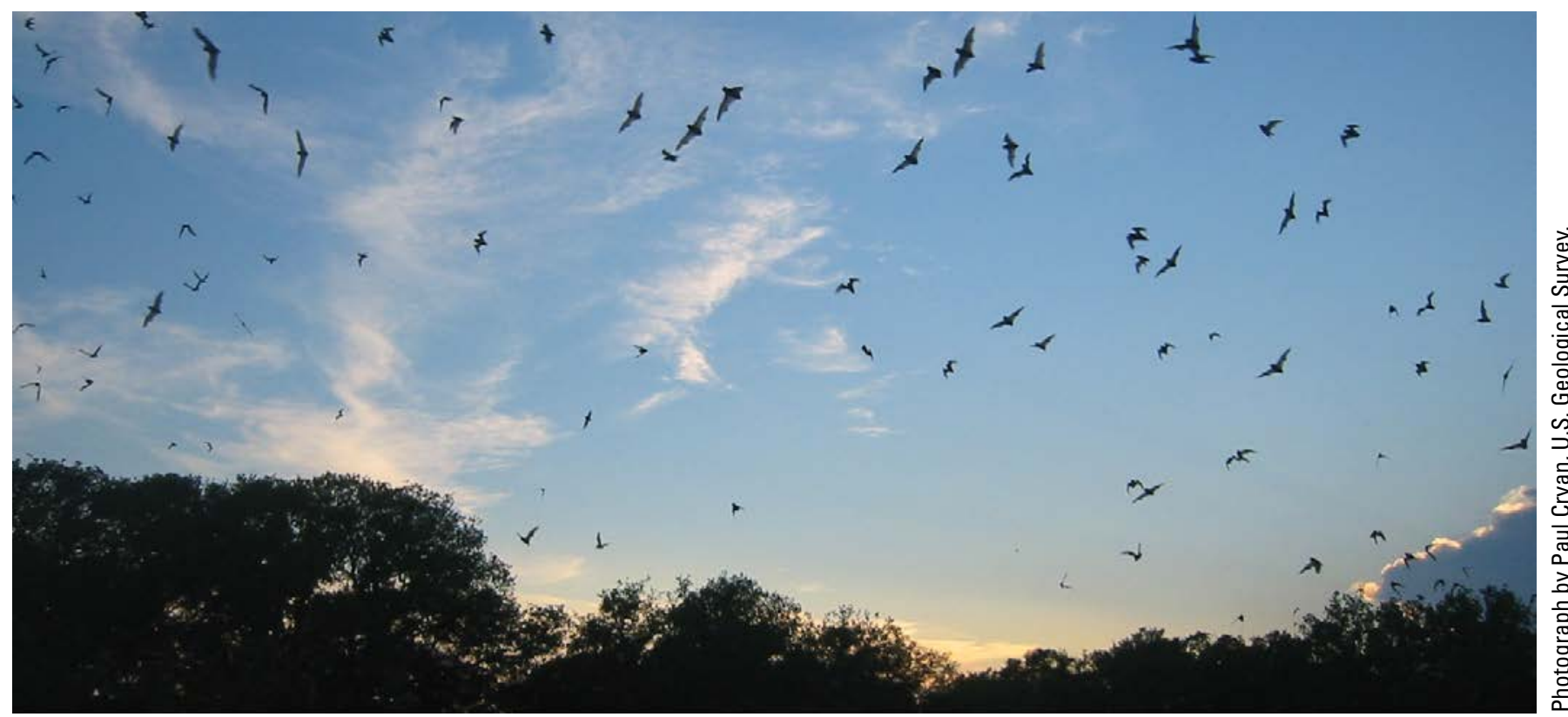

Bats emerging from the trees in the early evening sky.

\section{Bats and Land-Based Wind Energy}

Insect-eating bats provide pest control and pollination services worth billions of dollars to farmers annually (Boyles and others, 2011), but bat populations nationwide are being threatened by an invasive fungal disease (white-nose syndrome; WNS), wind turbines (Cryan and others, 2014), habitat loss, and other stressors. The projects listed below describe USGS studies on bat migration and distribution, bat behavior near wind turbines, strategies and tools to deter bats from turbines, and statistical methods to assess bat fatalities. This research, combined with studies on the cause, distribution, and control techniques of WNS, assist State and Federal land managers and the energy industry to site and manage wind farms to reduce conflict between bats and wind energy production.

\section{Bat Migration and Distribution}

\section{The North American Bat Monitoring Program (NABat)}

The USGS leads the North American Bat Monitoring Program (NABat; https://nabatmonitoring.org/), a multiorganizational program whose participants include State and Federal agencies, Native American tribes, universities, NGOs, and private industry partners such as Duke Energy. NABat members work to better understand the health of North America's bat populations, including current and future impacts from WNS and wind

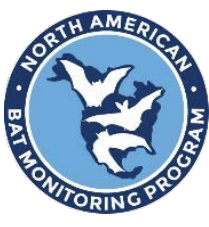
energy. The mission of NABat is to help resource managers and industry partners map bat distributions, better estimate extinction risk, and evaluate the effectiveness of conservation actions. The USGS has developed online data management and collaboration tools for bat monitoring, including services for archiving acoustic recordings collected at or near wind energy facilities. Thus far, NABat monitoring data have been collected in 47 States and 10 Canadian Provinces. In 2019, new analyses are planned to provide information on status and trends in occurrence of hoary bats and little brown bats across the Pacific Northwest and baseline distribution maps for 18 species in Colorado and 6 species in South Carolina. Additional products will include the first protocol for NABat that includes detailed standard operating procedures for detector deployment and other necessary specifications for defensible statistical analyses.

\section{Contact}

Brian Reichert, USGS Fort Collins Science Center, breichert@usgs.gov, (970) 226-9245 


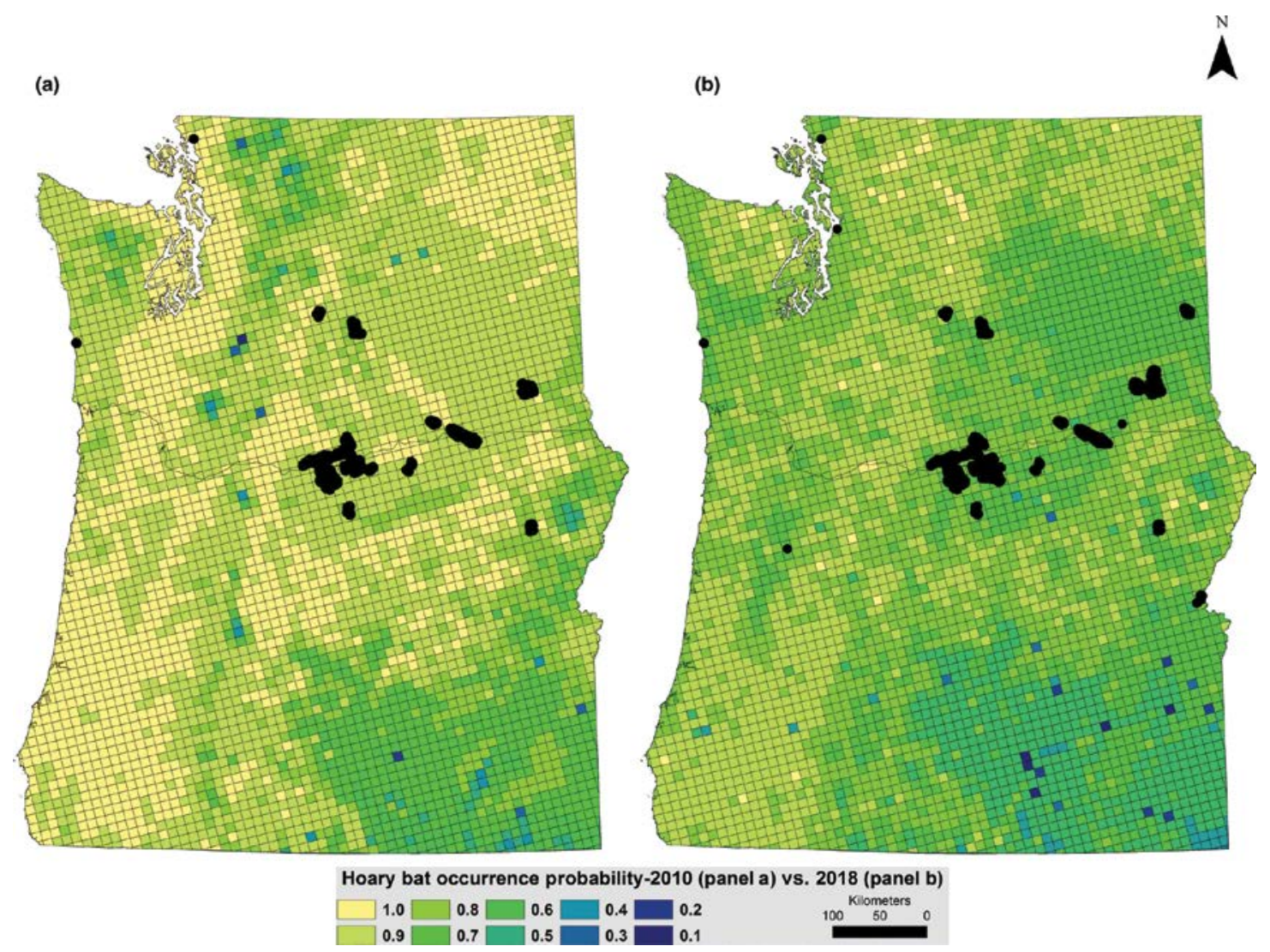

Hoary bat predicted occurrence probability maps for Oregon and Washington for (a) 2010 and (b) 2018. Image from Rodhouse and others (2019), Creative Commons 4.0 license.

\section{Publications}

Banner, K.M., Irvine, K.M., Rodhouse, T.J., Donner, D., and Litt, A.R., 2019, Online supporting information for "Statistical power of dynamic occupancy models to identify temporal change-Informing the North American Bat Monitoring Program": U.S. Geological Survey software release, https://doi.org/10.5066/P9WHOH6D.

Banner, K.M., Irvine, K.M., Rodhouse, T.J., Donner, D., and Litt, A.R., 2019, Statistical power of dynamic occupancy models to identify temporal change-Informing the North American Bat Monitoring Program: Ecological Indicators, v. 105, p. 166-176, https://doi.org/10.1016/j.ecolind.2019.05.047.

Banner, K.M., Irvine, K.M., Rodhouse, T.J., Wright, W.J., Rodriguez, R.M., and Litt, A.R., 2018, Improving geographically extensive acoustic survey designs for modeling species occurrence with imperfect detection and misidentification: Ecology and Evolution, v. 8, no. 12, p. 6144-6156, https://doi.org/10.1002/ece3.4162.

Irvine, K.M., 2019, Bat occupancy model predictions for Montana from acoustic and mist net data 2008-2010: U.S. Geological Survey data release, https://doi.org/10.5066/P9RBBSKZ.

Irvine, K.M., Rodhouse, T.J., Wright, W.J., and Olsen, A.R., 2018, Occupancy modeling species-environment relationships with non-ignorable survey designs: Ecological Applications, v. 28, no. 6, p. 1616-1625, https://doi.org/10.1002/eap.1754.

Reichert, B., Lausen, C., Loeb, S., Weller, T., Allen, R., Britzke, E., Hohoff, T., Siemers, J., Burkholder, B., Herzog, C., and Verant, M., 2018, A guide to processing bat acoustic data for the North American Bat Monitoring Program (NABat): U.S. Geological Survey Open-File Report 2018-1068, 33 p., https://doi.org/10.3133/ofr20181068.

Rodhouse, T.J., Rodriguez, R.M., Banner, K.M., Ormsbee, P.C., and Irvine, K.M., 2019, Evidence of region-wide bat population decline from long-term monitoring and Bayesian occupancy models with empirically informed priors: Ecology and Evolution, early view, posted September 11, 2019, 11 p., https://doi.org/10.1002/ece3.5612.

Rodriguez, R.M., Rodhouse, T.J., Barnett, J., Irvine, K.M., Banner, K.M., Lonnecker, J., and Ormsbee, P.C., 2019, North American Bat Monitoring Program regional protocol for surveying with stationary deployments of echolocation recording devices: Fort Collins, Colo., U.S. Department of the Interior, National Park Service, Natural Resource Report NPS/UCBN/ NRR—2019/1975, 33 p., https://irma.nps.gov/DataStore/Reference/Profile/2265647. 


\section{Indiana Bat Maternity Habitat Requirements in Missouri}

Wind turbine collisions and white-nose syndrome (WNS) can intensify the decline of endangered Indiana bat populations in the Midwestern United States. To better understand summer habitat requirements and drivers of Indiana bat maternity roost selection, the USGS partnered with the USFWS to examine maternity habitat selection in national wildlife refuges in Missouri. The project is evaluating broad-scale habitat associations, such as a preference for bottomland hardwood forests in close proximity to water, as well as testing for the differences in habitat characteristics between primary and alternate roosts. Scientists are examining differences in tree size and canopy cover between primary and alternate roosts and the role of temperature in influencing use of primary or alternate roosts. Results can provide new information on the importance of alternate roosts and smaller interior snags to the health and survival of maternity colonies.

Contact

Elisabeth B. Webb, USGS Missouri Cooperative Fish and Wildlife Research Unit, webbli@missouri.edu, (573) 882-2591

\section{Bat Conservation and Recovery in Nebraska and Wyoming}

There are mounting concerns for North American bats due to continuing and emerging threats from disease, habitat loss and fragmentation, and wind energy development. Because these threats are likely to increase in severity, there is an opportunity to improve the resiliency of summer bat habitats, learn how these threats impact local bat populations, and establish regional monitoring that can inform local and national resource management decisions. The USGS is collaborating with the Nebraska Game and Parks Commission, the Wyoming Game and Fish Department, and State and Federal natural resource managers in the Midwest to develop a strategic approach to bat conservation across Wyoming and Nebraska by monitoring impacts of disease, habitat fragmentation, and wind energy development on bat populations to provide decision makers with decision support tools and a bat conservation plan.

\section{Contact}

Kevin Pope, USGS Nebraska Cooperative Fish and Wildlife Research Unit, kpope2@unl.edu, (402) 472-7028

\section{Pre- and Post-Hibernation and Migratory Activity of Bats in the Central Appalachians}

The USGS and Virginia Polytechnic Institute and State University used fixedsite, long-term acoustical monitoring near cave systems and along mountain ridgelines and adjacent side slopes in Virginia and West Virginia to determine the timing of hibernation and migratory pulses for the endangered Indiana bat, threatened northern long-eared bat, and eastern red bat. Activities related to date, hourly wind speeds, and ambient temperatures were analyzed to determine drivers of activity in autumn and spring. These data provide further evidence that operational mitigation strategies at wind energy facilities could help protect migratory bat species and could be used to inform siting decisions for proposed wind energy facilities to lessen the potential impacts on migratory bats that use Appalachian ridges as their primary migration corridors.

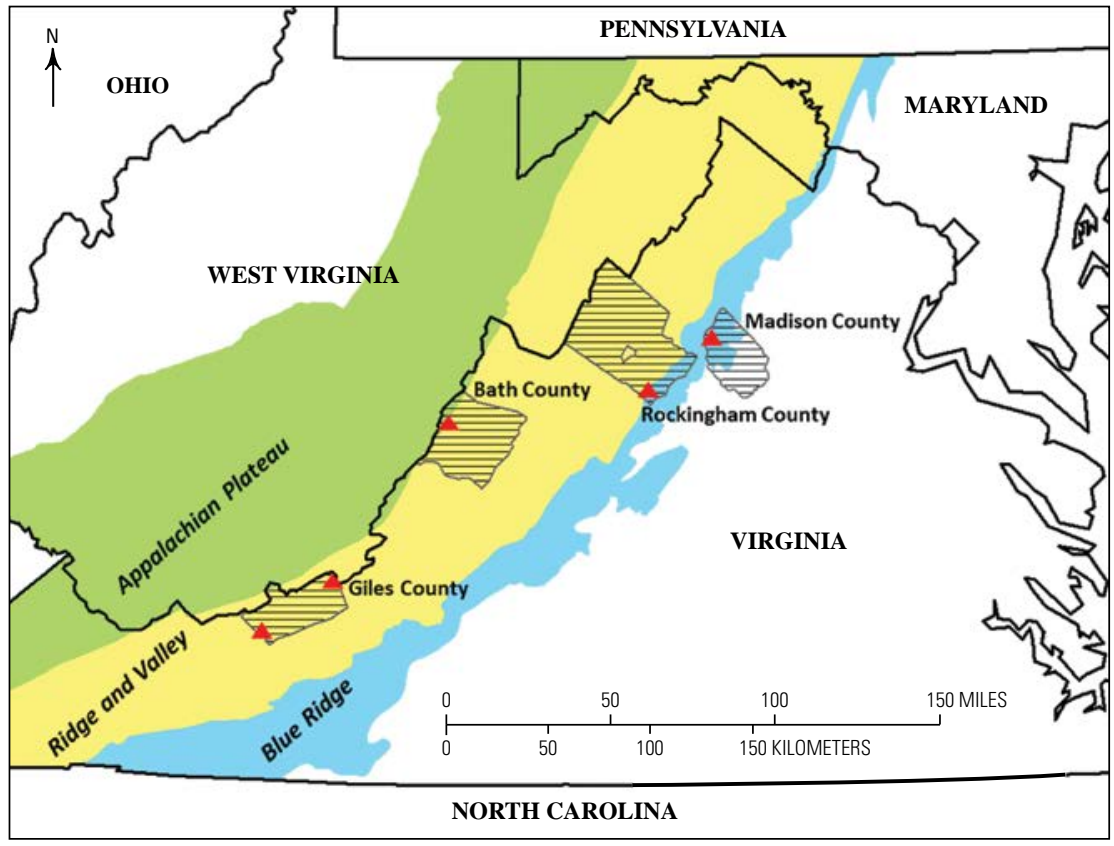

Approximate locations of five ridges sampled in the central Appalachians of Virginia (from Muthersbaugh and others, 2019). 


\section{Contact}

W. Mark Ford, USGS Virginia Cooperative Fish and Wildlife Research Unit, wmford@vt.edu, (540) 231-5927

Publication

Muthersbaugh, M.S., Ford, W.M., Powers, K.E., and Silvis, A., 2019, Activity patterns of bats during the fall and spring along ridgelines in the central Appalachians: Journal of Fish and Wildlife Management, v. 10, no. 1, p. 180-195, https://doi.org/10.3996/082018-JFWM-072.

\section{Mid-Atlantic Coastal Bat and Acoustic Nano-Tag Study}

Scientists from the Virginia Department of Game and Inland Fisheries, the USGS, and Virginia Polytechnic Institute and State University are studying migration timing and habitat use of eastern red bats in coastal areas of Virginia. With the move to develop coastal wind energy resources, there is a need to understand the potential for migration disruption and possible additive mortality of red bats and other migratory species. By understanding the timing of migration and offshore movements of these bats, it may be possible to design and implement wind energy mitigation measures, such as seasonal curtailment and (or) siting, to minimize interactions with bats. Eastern red bats along the coast of Virginia, Maryland, and New Jersey are being captured and outfitted with high-frequency nano-tags. Fixed sensor towers capable of tracking multiple bats simultaneously have been placed along the Virginia outer coast and in the Chesapeake Bay. Long-term acoustic data collected year-round at various coastal sites provide additional insight. Initial results regarding nano-tag retention time and bat migratory movements are being analyzed to help guide full-scale deployment in 2019 and 2020. As in the Appalachian region, long-term acoustic data suggest that migratory bat movements in the coastal areas are influenced by seasonal and weather interactions.

\section{Contact}

W. Mark Ford, USGS Virginia Cooperative Fish and Wildlife Research Unit, wmford@vt.edu, (540) 231-5927

\section{Post-White-Nose Syndrome Assessment of Bat Distribution in the Mid-Atlantic and Northeast}

The USGS and Virginia Polytechnic Institute and State University, in cooperation with the USFWS, the National Park Service, the U.S. Army, the U.S. Marine Corps, the Virginia Department of Game and Inland Fisheries, and the National Council for Air and Stream Improvement, are using multiyear acoustic data from more than 1,200 locations from the Appalachian Mountains to the Atlantic Coast, and from Virginia to New England, to determine post-WNS distribution and the community structure of bats, including northern long-eared bats. These data are being used to model current and future potential occupancy from the individual forest to landscape level. Results can be used to inform managers and regulators of the likelihood that a rare, threatened, or endangered bat species may be found in or near wind energy development, surface mining, or oil and gas development activities on public lands. This project can also provide information on the level of effort required for acoustic monitoring of the endangered Indiana bat and threatened northern long-eared bat.

\section{Contact}

W. Mark Ford, USGS Virginia Cooperative Fish and Wildlife Research Unit, wmford@vt.edu, (540) 231-5927

\section{Publications}

De La Cruz, J.L., Deeley, S., Muthersbaugh, M., Freeze, S.R., Kalen, N., and Silvis, A., 2019, Occupancy and detection probability of northern long-eared bats and other WNS-impacted species in the northeastern United States: Hadley, Mass., U.S. Fish and Wildlife Service, 133 p.

Ford, W.M., Silvis, A., Rodrigue, J.L., Kniowski, A.B., and Johnson, J.B., 2016, Deriving habitat models for northern longeared bats from historical detection data-A case study using the Fernow Experimental Forest: Journal of Fish and Wildlife Management, v. 7, no. 1, p. 86-98, https://doi.org/10.3996/012015-jfwm-004.

Nocera, T., Ford, W.M., Silvis, A., and Dobony, C.A., 2019, Patterns of acoustical activity of bats prior to and 10 years after WNS on Fort Drum Army Installation, New York: Global Ecology and Conservation, v. 18, e00633, 9 p., https://doi.org/10.1016/j.gecco.2019.e00633. 
Reynolds, R.J., Powers, K.E., Orndorff, W., Ford, W.M., and Hobson, C.S., 2016, Changes in rates of capture and demographics of M yotis septentrionalis (northern long-eared bat) in western Virginia before and after onset of white-nose syndrome: Northeastern Naturalist, v. 23, no. 2, p. 195-204, https://doi.org/10.1656/045.023.0201.

Silvis, A., Perry, R.W., and Ford, W.M., 2016, Relationships of three species of bats impacted by white-nose syndrome to forest condition and management: U.S. Forest Service Southern Research Station, General Technical Report SRS-214, 48 p., https://www.fs.usda.gov/treesearch/pubs/52250.

St. Germain, M.J., Kniowski, A.B., Silvis, A., and Ford, W.M., 2017, Who knew? First M yotis sodalis (Indiana bat) maternity colony in the coastal plain of Virginia: Northeastern Naturalist, v. 24, no. 1, p. N5-N10, https://doi.org/10.1656/045.024.0110.

\section{Modeling Foraging Habitat Suitability of the Hawaiian Hoary Bat}

USGS and University of Hawai' $i$ at Hilo scientists are using thermal videography and echolocation sampling methods to more directly determine the occurrence and activity of the endangered Hawaiian hoary bat, a tree-roosting species. Foraging habitat suitability is being related to bat occurrence, the frequency of feeding events, and insect abundance by using multistate occupancy models, which can be more informative than simple models of presence and assumed absence. This approach may allow managers to evaluate the relative importance of different areas to foraging bats and track the effects of habitat restoration efforts over time. Scientists also tested the utility of genetic markers to identify the sex of Hawaiian hoary bats. Using this method for sexing of these bats can permit reliable evaluation of the ratio of males to females in subpopulations affected by emerging threats, including timber harvest practices, entanglement on barbed-wire fencing, exposure to pesticides, and fatal collisions with wind turbines.

\section{Contact}

Marcos Gorresen, USGS Pacific Island Ecosystems Research Center, mgorresen@usgs.gov, (808) 985-6407

\section{Publications}

Gorresen, P.M., Brinck, K.W., DeLisle, M.A., Montoya-Aiona, K., Pinzari, C.A., and Bonaccorso, F.J., 2018, Multi-state occupancy models of foraging habitat use by the Hawaiian hoary bat (Lasiurus cinereus semotus): PLOS ONE, v. 13, no. 10, e0205150, 14 p., https://doi.org/10.1371/journal.pone.0205150.

Pinzari, C., Peck, R., Zinn, T., Gross, D., Montoya-Aiona, K., Brinck, D., Gorresen, M., and Bonaccorso, F., 2019, Hawaiian hoary bat (Lasiurus cinereus semotus) activity, diet, and prey availability at the Waihou Mitigation Area, Maui: Hilo, Hawai' $i$, University of Hawai'i at Hilo, Technical Report HCSU-090, 60 p., http://hdl.handle.net/10790/4638.

Pinzari, C.A., and Bonaccorso, F.J., 2018, A test of sex specific genetic markers in the Hawaiian hoary bat and relevance to population studies: Hilo, Hawai'i, University of Hawai'i at Hilo, Technical Report HCSU-085, 10 p., http://hdl.handle. net/10790/4375.
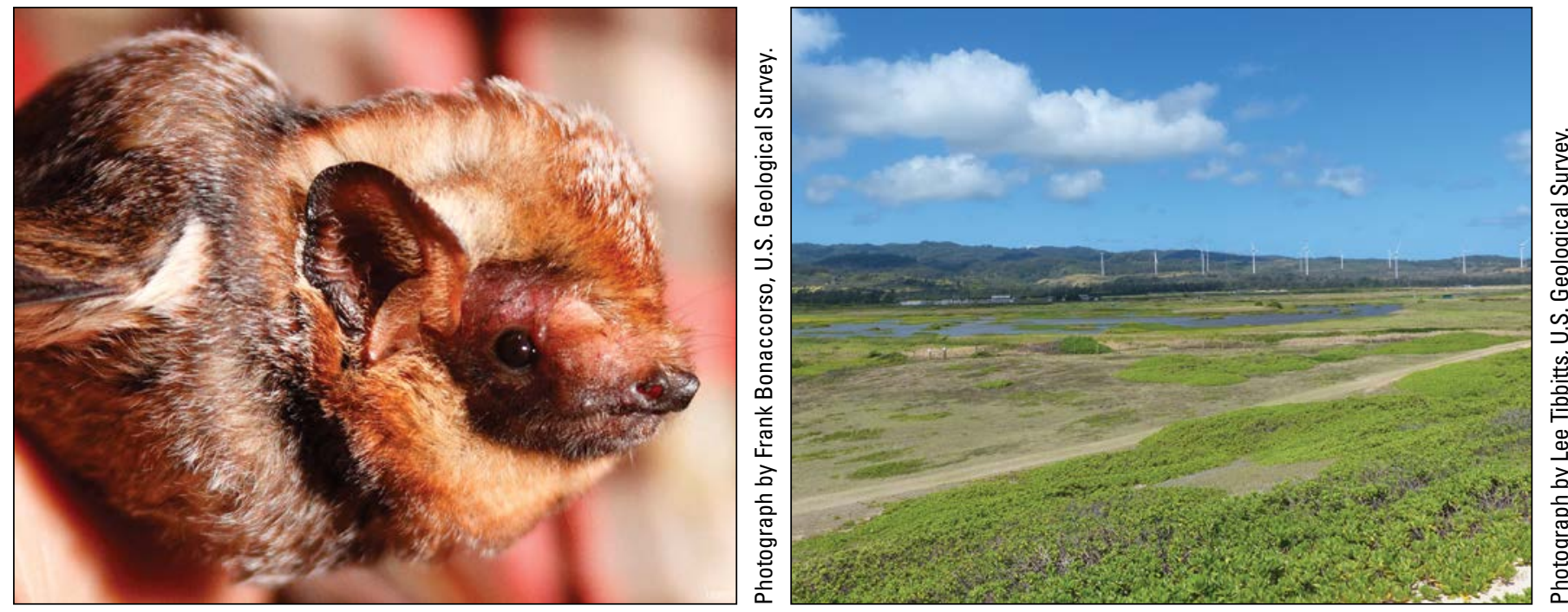

Left: An endangered Hawaiian hoary bat. Right: Coastal dunes of the Ki'i Unit in James Campbell National Wildlife Refuge on O'ahu, Hawai'i. 


\section{Bat Monitoring in the North Coast and Cascades Network of National Parks}

Due to a recent detection of WNS, a deadly bat fungal disease, in Washington State, the NPS is interested in the status and distribution of bats within the North Coast and Cascades Network of National Parks. USGS scientists are designing and evaluating bat sampling protocols for Mount Rainier, Olympic, and North Cascades National Parks that are compatible with NABat protocols. They are also developing a protocol to better understand the phenology of acoustic detections from low to high elevations. The new study provides baseline occupancy and distribution information and contributes to local, regional, and rangewide knowledge on the status and trends of multiple bat species, including at least two candidate species for State listing as threatened or endangered, Keen's myotis and Townsend's big-eared bat.

\section{Contact}

Kurt Jenkins, USGS Forest and Rangeland Ecosystem Science Center, kurt jenkins@usgs.gov, (360) 565-3041

\section{Distribution of Bat Species in Relation to Habitat Characteristics in Marin County, California}

USGS scientists have partnered with the NPS, the USFWS, California State Parks, Marin County Parks, and the Marin Municipal Water District to conduct a multispecies occupancy study across lands managed by four open-space agencies in Marin County, California, where 13 bat species potentially occur. The study will assess how bat species distributions are affected by landscape-level and microhabitat features that operate on many scales. Understanding the habitat characteristics that drive bat species richness or restrict habitat suitability for certain species may provide for opportunities to improve habitat management for bats.

\section{Contact}

Brian Halstead, USGS Western Ecological Research Center, bhalstead@usgs.gov, (530) 669-5076

\section{Bat Behavior Near Wind Turbines and Strategies to Minimize Adverse Impacts}

\section{Using Genomics to Determine History and Trends of a Bat Population Susceptible to Wind Turbines}

The hoary bat is a migratory species, seasonally moving hundreds of miles and ranging throughout most parts of the United States and Canada. Due to the cryptic nature of hoary bats and their disproportionately high mortality at wind energy facilities, there is uncertainty regarding the population status of the species. USGS researchers have partnered with the USFWS to investigate population history and trends of hoary bats in North America by using genomic techniques to provide useful information to resource managers tasked with assessing the impacts of wind energy development on current populations of the species. Specifically, the USGS is sequencing the genomes of hoary bats found dead at wind turbines over a timespan of about 10 years to test for indications of population change by comparing the genomes of turbine fatalities gathered in recent years to those gathered in the previous decade. In addition, studies will estimate historical sizes of hoary bat populations, spanning from approximately 10,000 to over 1 million years before present, to determine how big (or small) the population has ever been, as well as how quickly the population has changed over time. New genetic methods for estimating population trends can assist conservation managers in management of bats facing potential population declines and could be applied toward recovery of endangered bat species, such as the Indiana bat.

\section{Contact}

Sara Oyler-McCance, USGS Fort Collins Science Center, sara_oyler-mccance@usgs.gov, (970) 226-9197

\section{Publication}

Oyler-McCance, S.J., Fike, J.A., Lukacs, P.M., Sparks, D.W., O’Shea, T.J., and Whitaker, J.O., Jr., 2018, Genetic mark-recapture improves estimates of maternity colony size for Indiana bats: Journal of Fish and Wildlife Management, v. 9, no. 1, p. 25-35, https://doi.org/10.3996/122016-JFWM-093. 


\section{Bat Behavior and Fatalities at Wind Energy Facilities}

Migratory bat species that roost in trees, or tree bats, are disproportionately affected by wind turbines, in part because they appear to be attracted to these structures. USGS science has led to new discoveries about these species, such as the consistent patterns in which tree bats approach and interact with turbines at night. USGS scientists have also identified areas of the continent where mortality risk might be higher, such as the Great Plains, the Great Lakes region, and areas adjacent to coastal wintering areas. Currently, USGS scientists are using this new information about bat behaviors, seasonal distribution, and perception to develop efficient and effective ways of reducing bat interactions with wind turbines.

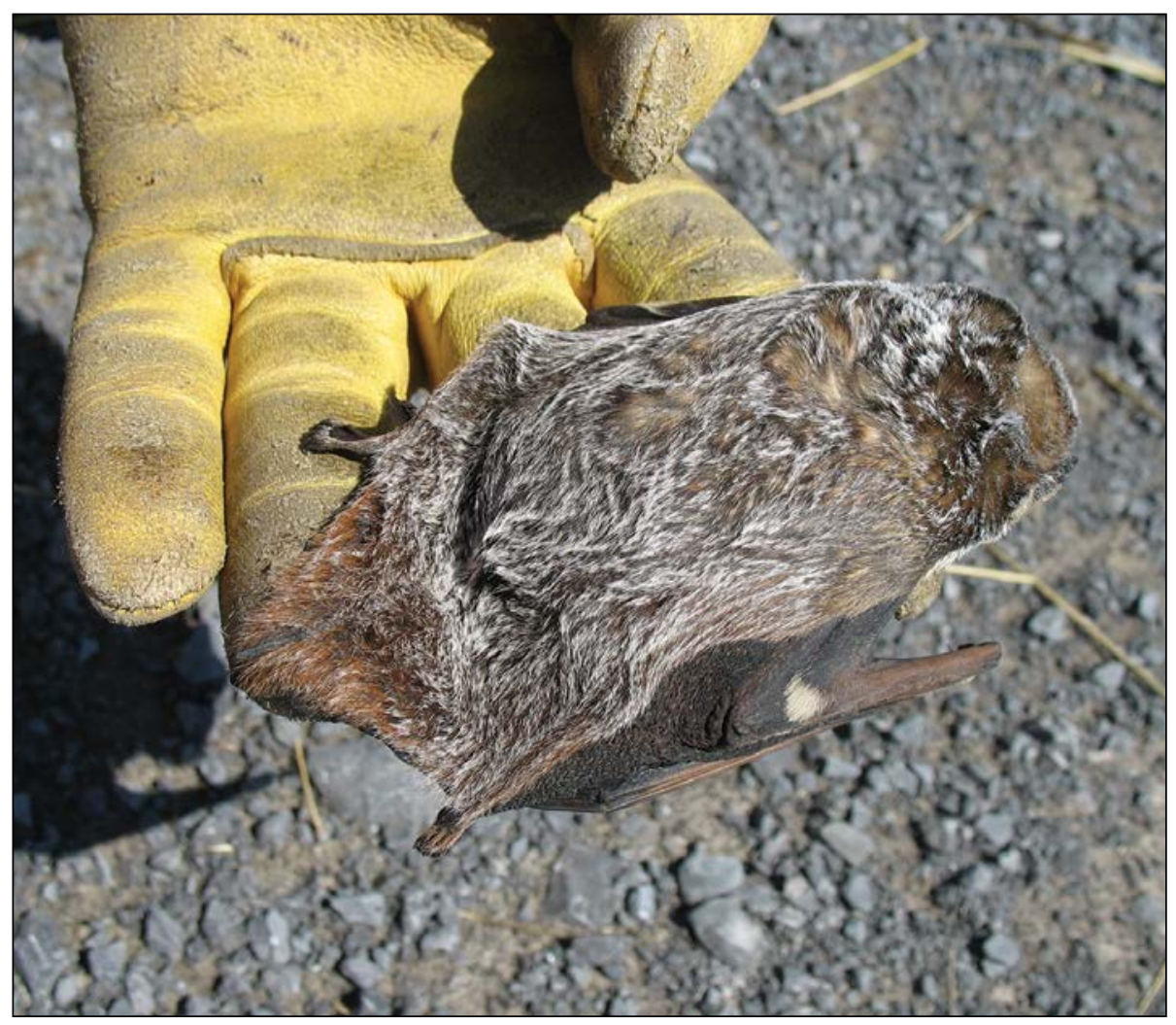

A hoary bat found dead beneath a wind turbine. Photograph by Paul Cryan, U.S. Geological Survey.

\section{Contact}

Paul Cryan, USGS Fort Collins Science Center, cryanp@usgs.gov, (970) 226-9389

\section{Publications}

Hayman, D.T.S., Cryan, P.M., Fricker, P.D., and Dannemiller, N.G., 2017, Long-term video surveillance and automated analyses reveal arousal patterns in groups of hibernating bats: Methods in Ecology and Evolution, v. 8, no. 12, p. 1813-1821, https://doi.org/10.1111/2041-210X.12823.

O'Shea, T.J., Cryan, P.M., and Bogan, M.A., 2018, United States bat species of concern-A synthesis: Proceedings of the California Academy of Sciences, v. 65, supplement 1, p. 1-279, https://pubs.er.usgs.gov/publication/70200786.

O'Shea, T.J., Cryan, P.M., Hayman, D.T.S., Plowright, R.K., and Streicker, D.G., 2016, Multiple mortality events in bats-A global review: Mammal Review, v. 46, no. 3, p. 175-190, https://doi.org/10.1111/mam.12064. 


\section{Ultraviolet Illumination as a Means of Reducing Bat Activity and Risk at Wind Turbines}

Insectivorous bats are known for their ability to find and pursue flying insect prey at close range using echolocation, but they also rely heavily on vision. Using a cue that only bats would perceive, the USGS is developing and testing technologies to prevent bats from approaching wind turbines that might be mistaken for trees. USGS scientists are collaborating with the National Renewable Energy Laboratory through a U.S. Department of Energy (DOE) Technology Development and Innovation award on refining a selectively perceptible wind turbine system to prevent bat fatalities. This project is testing whether dim, flickering, and position-shifting ultraviolet (UV) light can deter bats from approaching turbines. Results from this and related research could determine whether dim UV light can reduce bat activity and fatality at operational wind farms, with the potential benefit of allowing operators to run turbines at maximum efficiency.

\section{Contact}

Paul Cryan, USGS Fort Collins Science Center, cryanp@usgs.gov, (970) 226-9389

\section{Publications}

Cryan, P.M., Dalton, D.C., and Gorresen, P.M., 2018, Selectively perceptible wind turbine system: U.S. Patent no. US 20160169501 A1, 8 p., https://patentimages. storage.googleapis.com/ab/51/7c/1806ca0421d3ac/US9995282.pdf.

Gorresen, P.M., Cryan, P.M., Dalton, D.C., Wolf, S., and Bonaccorso, F.J., 2015, Ultraviolet vision may be widespread in bats: Acta Chiropterologica, v. 17, no. 1, p. 193-198, https://doi.org/10.3161/15081109acc2015.17.1.017.

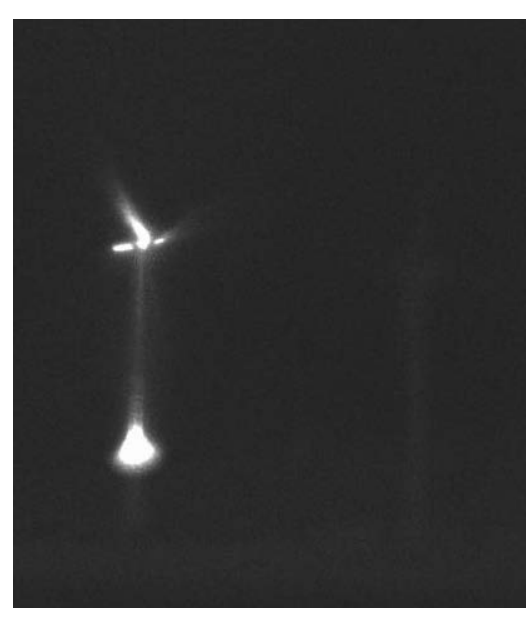

A wind turbine is dimly lit with flickering ultraviolet (UV) light and imaged by using a video camera sensitive to UV light. Image from video clip by Paul Cryan, U.S. Geological Survey.

Gorresen, P.M., Cryan, P.M., Dalton, D.C., Wolf, S., Johnson, J.A., Todd, C.M., and Bonaccorso, F.J., 2015, Dim ultraviolet light as a means of deterring activity by the Hawaiian hoary bat Lasiurus cinereus semotus: Endangered Species Research, v. 28, no. 3, p. 249-257, https://doi.org/10.3354/esr00694.

\section{Wind Energy Effects on Mexican Free-Tailed Bats}

USGS scientists and collaborators at the University of Arizona are studying the interactions of Mexican free-tailed bats (MFTB) with wind energy facilities and how bat fatalities at wind energy facilities may influence pest control services provided by MFTB to farmers in the Southwest. Scientists are using seasonal distribution models of MFTB and a full life cycle demographic model as well as data about roost locations; known wind turbine locations and bat fatalities; and locations of cotton, corn, and sorghum crops to address this question.

\section{Contact}

Jay Diffendorfer, USGS Geosciences and Environmental Change Science Center, jediffendorfer@usgs.gov, (303) 236-5369

\section{Publications}

Haefele, M.A., Loomis, J.B., Merideth, R., Lien, A., Semmens, D.J., Dubovsky, J., Wiederholt, R., Thogmartin, W.E., Huang, T.-K., McCracken, G., Medellin, R.A., Diffendorfer, J.E., and López-Hoffman, L., 2018, Willingness to pay for conservation of transborder migratory species - A case study of the Mexican free-tailed bat in the United States and Mexico: Environmental Management, v. 62, no. 2, p. 229-240, https://doi.org/10.1007/s00267-018-1046-1.

López-Hoffman, L., Diffendorfer, J., Wiederholt, R., Bagstad, K.J., Thogmartin, W.E., McCracken, G., Medellin, R.L., Russell, A., and Semmens, D.J., 2017, Operationalizing the telecoupling framework for migratory species using the spatial subsidies approach to examine ecosystem services provided by Mexican free-tailed bats: Ecology and Society, v. 22, no. 4, 8 p., https://doi.org/10.5751/ES-09589-220423. 


\section{Wind Turbine Curtailment Strategies to Reduce Bat Fatality}

Wildlife fatalities due to collisions with wind turbines have sparked efforts to reduce the number of fatalities through operational management. Recent studies have shown that altering turbine operations when winds are below certain speeds can decrease the number of bat fatalities, but questions remain regarding optimal management. The USGS and colleagues are modeling the proportion of bat fatalities occurring under varying meteorological conditions at Avangrid Renewables' Blue Creek Wind Farm in Ohio to identify conditions that minimize both bat fatalities and energy production loss. USGS scientists are also investigating whether accurate and precise estimates of fatalities can be derived from carcass searches conducted at easily accessed areas, such as roads and pads beneath turbines.

\section{Contact}

Manuela M. Huso, USGS Forest and Rangeland Ecosystem Science Center, mhuso@usgs.gov, (541) 750-0948

\section{Comparing the Effectiveness of Acoustic Deterrents to Operational Curtailment in Reducing Bat Fatality}

Independent studies have shown that both operational curtailment and ultrasonic acoustic deterrents can be effective in reducing bat fatalities at wind energy facilities. A primary goal of this study, co-funded by the DOE, USGS, and Bat Conservation International (BCI), is to compare the costs and benefits of acoustic deterrents to operational curtailment. Fatality rates, when both curtailment and acoustic deterrents are applied singly and in combination, are being compared with fatality rates at untreated turbines to determine if one of these methods is more effective, if they are equally effective, or if they might act synergistically when employed simultaneously.

\section{Contact}

Manuela M. Huso, USGS Forest and Rangeland Ecosystem Science Center, mhuso@usgs.gov, (541) 750-0948

\section{Additional Publications}

Gorresen, P.M., Cryan, P.M., Montoya-Aiona, K., and Bonaccorso, F.J., 2017, Do you hear what I see? Vocalization relative to visual detection rates of Hawaiian hoary bats (Lasiurus cinereus semotus): Ecology and Evolution, v. 7, no. 17, p. 6669-6679, https://doi.org/10.1002/ece3.3196.

Thompson, M., Beston, J.A., Etterson, M., Diffendorfer, J.E., and Loss, S.R., 2017, Factors associated with bat mortality at wind energy facilities in the United States: Biological Conservation, v. 215, p. 241-245, https://doi.org/10.1016/j.biocon. 2017.09.014.

Weller, T.J., Castle, K.T., Liechti, F., Hein, C.D., Schirmacher, M.R., and Cryan, P.M., 2016, First direct evidence of long-distance seasonal movements and hibernation in a migratory bat: Scientific Reports, v. 6, article no. 34585,7 p., https://doi.org/10.1038/srep34585. 


\section{Raptors and Land-Based Wind Energy}

Raptors are susceptible to collisions with wind turbines, and populations may also be at risk from other anthropogenic hazards, such as electrocution and poisoning (Watson and others, 2018). USGS scientists study raptor ecology, movement, distribution, and habitat requirements and are advancing Global Positioning System (GPS) telemetry techniques to improve estimation of flight altitude and further refine models of golden eagle and California condor flight behavior over landscapes that are amenable to wind energy development. These efforts and other research on novel monitoring methods to study raptor breeding, survival, fatalities, and potential mitigation strategies can assist State and Federal land managers in managing raptor populations and the energy industry in siting projects to minimize potential risks to these species.

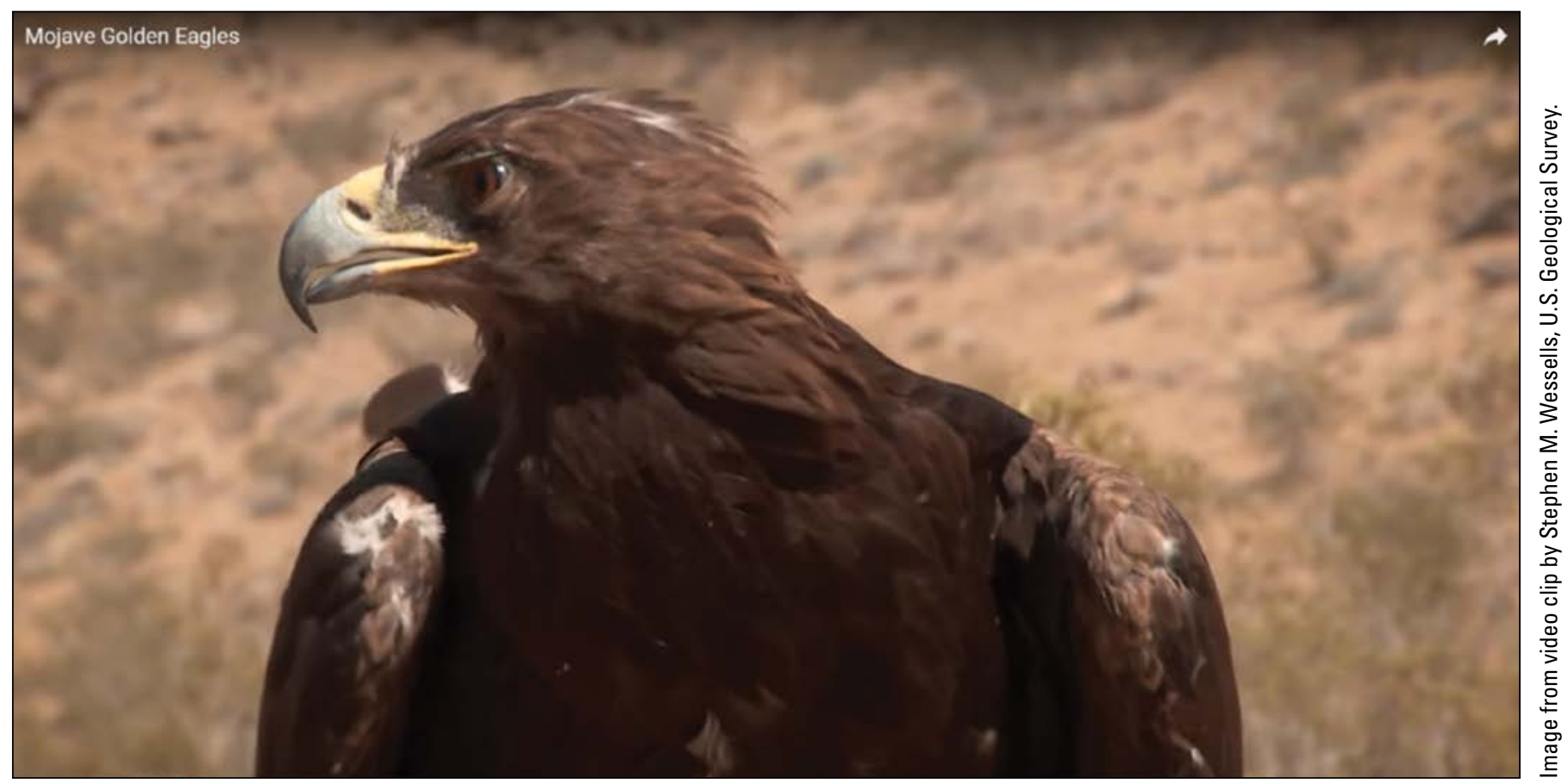

Mojave golden eagle.

\section{Golden Eagle Migration and Habitat Use}

The USGS is collecting information related to habitat use, home range, and population dynamics of golden eagles in the central Appalachians, California, New Mexico, the Mojave and Sonoran Deserts, and starting in 2019, Yellowstone National Park. Researchers are using various methodologies including Global Positioning System-Global System for Mobile (GPS-GSM)

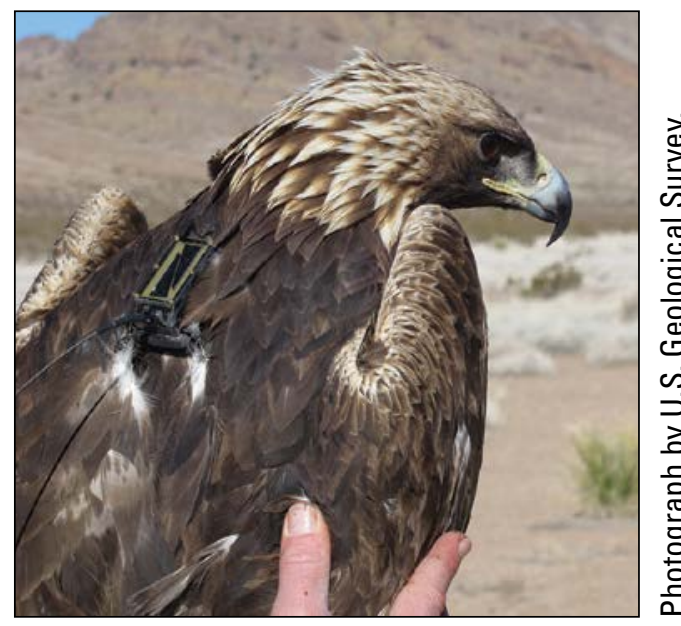
communications telemetry, standard geographic information system (GIS) analyses, nest visits, and non-invasive genetic monitoring. Data are used to model movement, resource use, and environmental drivers associated with reproduction and survival. Data are also used to create risk models to assist resource management agencies in evaluating management options for golden eagles. Results can inform resource managers about where and when eagles could be most at risk from disturbances associated with renewable energy structures. Data are being combined with datasets from similar projects to create a framework and baseline to build an effective long-term golden eagle monitoring program in support of adaptive management.

\section{Contact}

Todd E. Katzner, USGS Forest and Rangeland Ecosystem Science Center, tkatzner@usgs.gov, (208) 426-5232

At left: Golden eagle with a GPS backpack. 


\section{Publications}

Brown, J.L., Bedrosian, B., Bell, D.A., Braham, M.A., Cooper, J., Crandall, R.H., DiDonato, J., Domenech, R., Duerr, A.E., Katzner, T.E., Lanzone, M.J., LaPlante, D.W., McIntyre, C.L., Miller, T.A., Murphy, R.K., Shreading, A., Slater, S.J., Smith, J.P., Smith, B.W., Watson, J.W., and Woodbridge, B., 2017, Patterns of spatial distribution of golden eagles across North America - How do they fit into existing landscape-scale mapping systems?: Journal of Raptor Research, v. 51, no. 3, p. 197-215, https://doi.org/10.3356/JRR-16-72.1.

Dennhardt, A.J., Duerr, A.E., Brandes, D., and Katzner, T.E., 2017, Applying citizen-science data and mark-recapture models to estimate numbers of migrant golden eagles in an important bird area in eastern North America: The Condor, v. 119, no. 4, p. 817-831, https://doi.org/10.1650/CONDOR-16-166.1.

Duerr, A.E., Braham, M.A., Miller, T.A., Cooper, J., Anderson, J.T., and Katzner, T.E., 2019, Roost- and perch-site selection by golden eagles (Aquila chrysaetos) in eastern North America: Wilson Journal of Ornithology, v. 131, no. 2, p. 310-328, https://doi.org/10.1676/18-38.

Duerr, A.E., Miller, T.A., Dunn, L., Bell, D.A., Bloom, P.H., Fisher, R.N., Tracey, J.A., and Katzner, T.E., 2019, Topographic drivers of flight altitude over large spatial and temporal scales: The Auk, v. 136, no. 2, p. 1-11, https://doi.org/10.1093/auk/ ukz002.

Miller, T.A., Brooks, R.P., Lanzone, M.J., Cooper, J., O’Malley, K., Brandes, D., Duerr, A., and Katzner, T.E., 2017, Summer and winter space use and home range characteristics of golden eagles (Aquila chrysaetos) in eastern North America: The Condor, v. 119, no. 4, p. 697-719, https://doi.org/10.1650/CONDOR-16-154.1.

Pirotta, E., Katzner, T., Miller, T.A., Duerr, A.E., Braham, M.A., and New, L., 2018, State-space modelling of the flight behaviour of a soaring bird provides new insights to migratory strategies: Functional Ecology, v. 32, no. 9, p. 2205-2215, https://doi.org/10.1111/1365-2435.13180.

Rus, A.I., Duerr, A.E., Miller, T.A., Belthoff, J.R., and Katzner, T.E., 2017, Counterintuitive roles of experience and weather on migratory performance: The Auk, v. 134, no. 3, p. 485-497, https://doi.org/10.1642/AUK-16-147.1.

Sur, M., Duerr, A.E., Bell, D.A., Fisher, R.N., Tracey, J.A., Bloom, P.H., Miller, T.A., and Katzner, T.E., 2019, Relevance of individual and environmental drivers of movement of golden eagles: Ibis, accepted article posted August 13, 2019, 51 p., https://doi.org/10.1111/ibi.12766.

Sur, M., Suffredini, T., Wessells, S.M., Bloom, P.H., Lanzone, M., Blackshire, S., Sridhar, S., and Katzner, T., 2017, Improved supervised classification of accelerometry data to distinguish behaviors of soaring birds: PLOS ONE, v. 12, no. 4, e0174785, 19 p., https://doi.org/10.1371/journal.pone.0174785.

\section{Golden Eagle Movement and Conservation in Coastal Southern California}

To evaluate the effects of human activities on golden eagles in coastal southern California, the USGS began a multiyear golden eagle survey and tracking program in 2014, supported by the San Diego Association of Governments, the California Department of Fish and Wildlife, the USFWS, and the BLM. More than 40 golden eagles were captured in San Diego County, Orange County, and western Riverside County, California, and fitted with GPS backpack transmitters, allowing scientists to track their movements. Movements ranged as far north as northern Nevada and southern Wyoming and as far south as the southern tip of Baja California, Mexico. Researchers also developed habitat selection models and provided predictions of population-level habitat selection for golden eagles in San Diego County. Modeled results indicate strong avoidance of urban areas, moderate avoidance of exurban areas, and avoidance of a buffer around these landscapes. In contrast, eagles preferred more

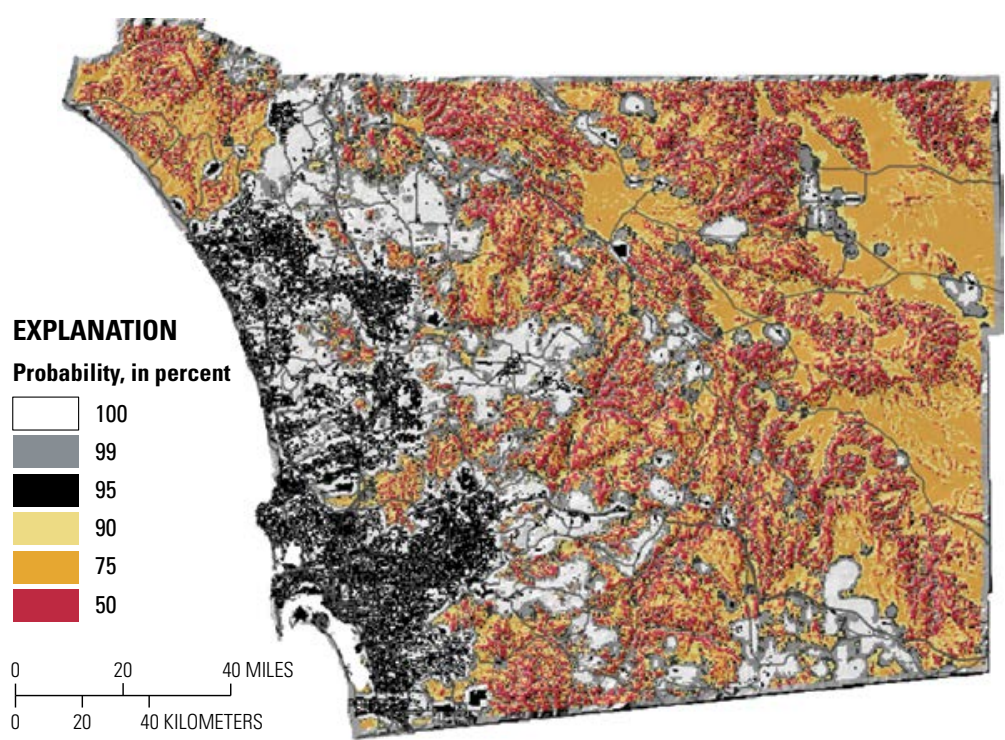

Contours of the population-level probabilities of golden eagle habitat selection (modified from Tracey and others, 2018). 
rugged areas in higher elevation terrain. This work contributes to a broader understanding of the population status, demography, resource use, and genetic structure of golden eagles across a wide gradient of environmental conditions.

\section{Contact}

Robert N. Fisher, USGS Western Ecological Research Center, rfisher@usgs.gov, (619) 225-6422

\section{Publications}

Tracey, J.A., Madden, M.C., Bloom, P.H., Katzner, T.E., and Fisher, R.N., 2018, Golden eagle (Aquila chrysaetos) habitat selection as a function of land use and terrain, San Diego County, California: U.S. Geological Survey Open-File Report 2018-1067, 13 p., https://doi.org/10.3133/ofr20181067.

Tracey, J.A., Madden, M.C., Sebes, J.B., Bloom, P.H., Katzner, T.E., and Fisher, R.N., 2016, Biotelemetry data for golden eagles (Aquila chrysaetos) captured in coastal southern California, November 2014-February 2016: U.S. Geological Survey Data Series 994, 32 p., https://doi.org/10.3133/ds994.

Tracey, J.A., Madden, M.C., Sebes, J.B., Bloom, P.H., Katzner, T.E., and Fisher, R.N., 2017, Biotelemetry data for golden eagles (Aquila chrysaetos) captured in coastal southern California, February 2016-February 2017: U.S. Geological Survey Data Series 1051, 35 p., https://doi.org/10.3133/ds1051.

\section{Population Demography of Golden Eagles Near Altamont Pass, California}

Wind turbines at the Altamont Pass Wind Resource Area in California have been estimated to cause fatalities of as many as 28 to 68 golden eagles annually. This study investigates how estimated levels of turbine-related mortality and other environmental stressors may interact to affect the population demography of golden eagles in the broader landscapes surrounding the wind farm. The USGS and partners are using historic and current eagle data to assess territory occupancy, abundance, breeding success, survival, and habitat use of different age classes of golden eagles. This information has been used to quantify how the local population of golden eagles may respond to observed levels of turbine-related fatalities. Additionally, results from this study are providing detailed information on specific sites or breeding areas that contribute most to overall population growth, which permits land managers to identify and prioritize important areas for conservation or inform repowering (the updating of wind turbines) of existing wind energy sites.

\section{Contact}

J. David Wiens, USGS Forest and Rangeland Ecosystem Science Center, jwiens@usgs.gov, (541) 750-0961

\section{Publications}

Hunt, W.G., Wiens, J.D., Law, P.R., Fuller, M.R., Hunt, T.L., Driscoll, D.E., and Jackman, R.E., 2017, Quantifying the demographic cost of human-related mortality to a raptor population: PLOS ONE, v. 12, no. 2, e0172232, 22 p., https://doi.org/10.1371/journal.pone.0172232.

Kolar, P.S., and Wiens, J.D., 2017, Distribution, nesting activities, and age-class of territorial pairs of golden eagles at the Altamont Pass Wind Resource Area, California, 2014-16: U.S. Geological Survey Open-File Report 2017-1035, 18 p., https://doi.org/10.3133/ ofr20171035.

Wiens, J.D., Kolar, P.S., Fuller, M.R., Hunt, W.G., and Hunt, T., 2015, Estimation of occupancy, breeding success, and predicted abundance of golden eagles (Aquila chrysaetos) in the Diablo Range, California, 2014: U.S. Geological Survey Open-File Report 2015-1039, 23 p., https://doi.org/10.3133/ofr20151039.

Wiens, J.D., Kolar, P.S., Hunt, W.G., Hunt, T., Fuller, M.R., and Bell, D.A., 2018, Spatial patterns in occupancy and reproduction of golden eagles during drought-Prospects for conservation in changing environments: The Condor, v. 120, no. 1, p. 106-124, https://doi.org/10.1650/CONDOR-17-96.1.

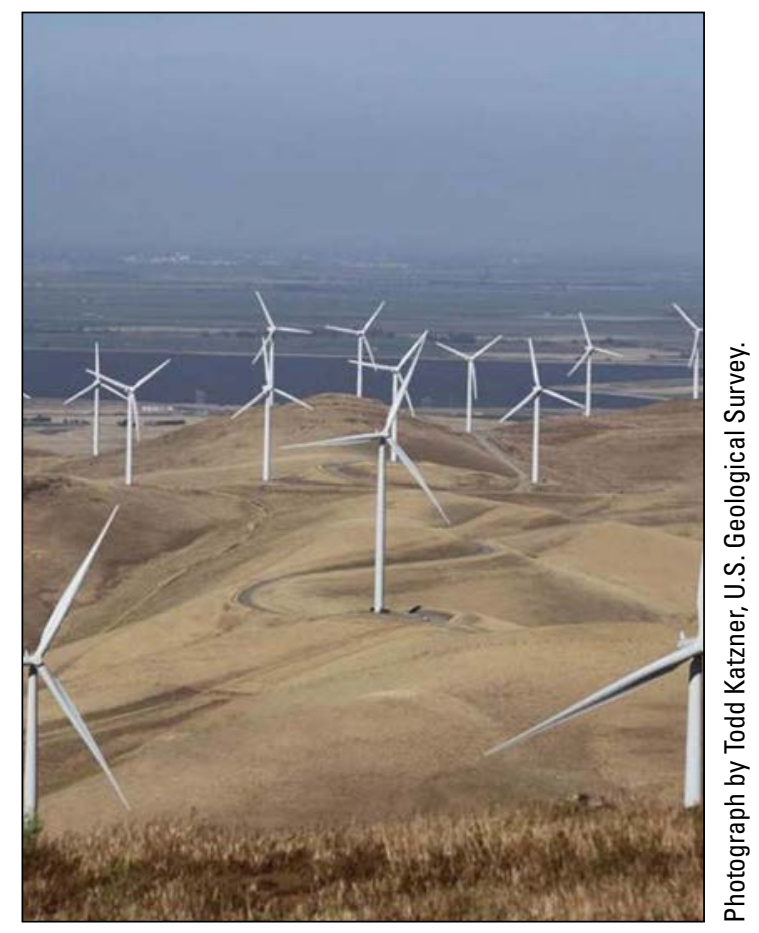

Wind turbines at the Altamont Pass wind farm in northern California. 


\section{Tracking Bald Eagles Near Wind Energy Facilities in the Central Great Plains}

The Central Great Plains is an important focus area for the development of new wind facilities. The USGS is leading an effort to track bald eagles using GPS-GSM telemetry to acquire information that will help wildlife managers address potential conflict between bald eagles and wind turbines in Oklahoma and collaborate on similar work in Iowa and Illinois. Scientists are collecting information on topography, weather, and land cover to understand how environmental conditions may put eagles at risk from collisions with turbines.

\section{Contact}

Todd E. Katzner, USGS Forest and Rangeland Ecosystem Science Center, tkatzner@usgs.gov, (208) 426-5232

\section{Condor Flight Behavior Near Wind Energy Facilities}

Scientists from the USGS, USFWS, California Department of Fish and Wildlife, and BLM are using high-frequency GPS-GSM telemetry to study flight responses of California condors to understand the risk these raptors face from potential wind energy development. Tracking 24 condors for nearly 2 years, researchers found that although the condors only occasionally flew at altitudes in the rotor-swept zone of turbines, they regularly used classes of winds preferred by wind energy developers. The collision risk to large soaring birds from turbines should be relatively lower over flatter, less rugged areas and in habitat used during daytime soaring. This information can be used by wind energy developers to predict and avoid the risk to condors from existing and proposed turbines.

\section{Contact}

Todd E. Katzner, USGS Forest and Rangeland Ecosystem Science Center, tkatzner@usgs.gov, (208) 426-5232

\section{Publications}

Hall, J.C., Braham, M.A., Nolan, L.A., Conley, J., Brandt, J., Mendenhall, L., Lanzone, M., McGann, A., and Katzner, T.E., 2019, Characteristics of feeding sites of California condors (Gymnogyps californianus) in the human-dominated landscape of Southern California: Wilson Journal of Ornithology, Online First article posted August 12, 2019, https://doi.org/10.1676/17-23.

Poessel, S.A., Brandt, J., Mendenhall, L., Braham, M.A., Lanzone, M.J., McGann, A.J., and Katzner, T.E., 2018, Flight response to spatial and temporal correlates informs risk from wind turbines to the California condor: The Condor, v. 120, no. 2, p. 330-342, https://doi.org/10.1650/CONDOR-17-100.1.

Poessel, S.A., Brandt, J., Miller, T.A., and Katzner, T.E., 2018, Meteorological and environmental variables affect flight behaviour and decision-making of an obligate soaring bird, the California condor G ymnogyps californianus: Ibis, v. 160, no. 1, p. 36-53, https://doi.org/10.1111/ibi.12531.

Poessel, S.A., Duerr, A.E, Hall, J.C., Braham, M.A., and Katzner, T.E., 2018, Improving estimation of flight altitude in wildlife telemetry studies: Journal of Applied Ecology, v. 55, no. 4, p. 2064-2070, https://doi.org/10.1111/1365-2664.13135.

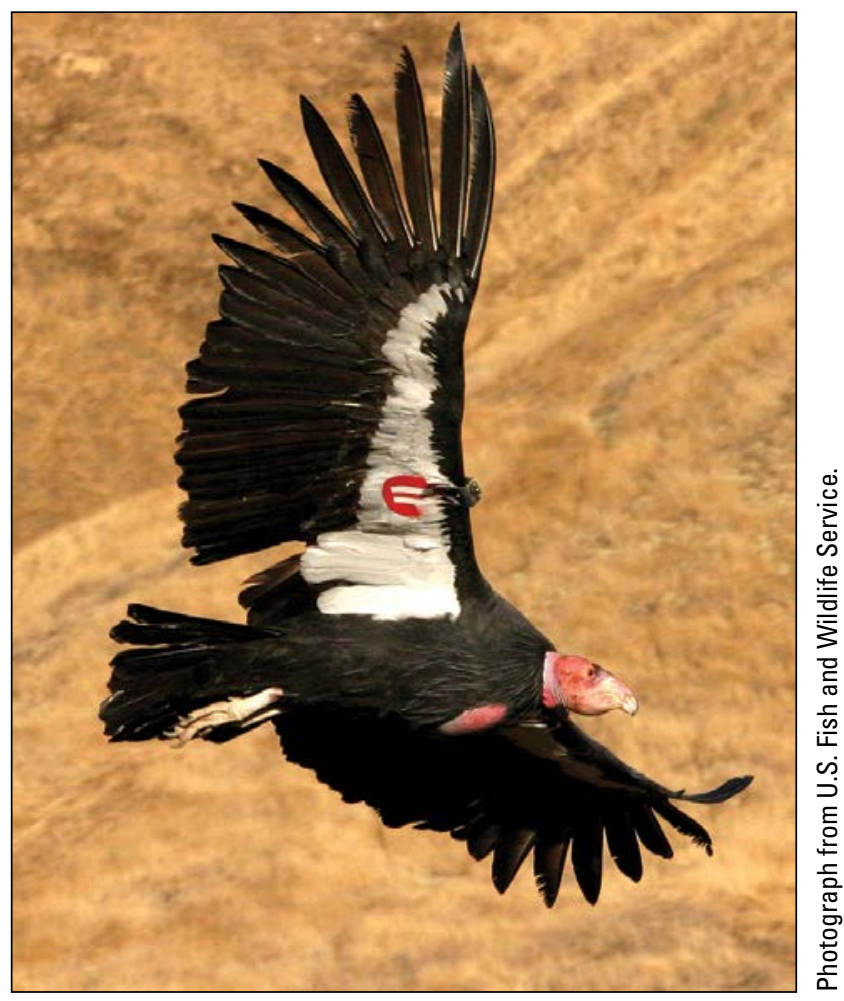

California condor. 


\section{Interactions of Juvenile Swainson's Hawks With Wind Energy Facilities During Dispersal and Migration}

Swainson's hawks are long-distance migratory raptors that breed across Western North America and migrate to Argentina for the winter. This annual round trip of approximately 20,000 kilometers, or 12,500 miles, takes the hawks over 12 countries that all have interests in wind energy development. Development of wind energy facilities in Texas and Argentina along the migration route of Swainson's hawks has raised concerns for potential risks to raptors from direct mortality and habitat loss due to wind facilities. This project, funded by the DOE, can provide survival estimates, movement data, and habitat use data for juvenile Swainson's hawks throughout their migrations. The data can help resource managers better understand and evaluate hemispheric-level risks to this species and similar long-distance migratory birds.

\section{Contact}

Clint Boal, USGS Texas Cooperative Fish and Wildlife Research Unit, cboal@usgs.gov, (806) 834-6536

\section{Publication}

Watson, K.A., Boal, C.W., Groen, L.M., and Walker, J.R., 2017, Using GPS transmitters to explore movement ecology and to assess risk of the wind energy industry for Swainson's hawks: U.S. Department of Energy Office of Scientific and Technical Information, Technical Report IROS-655, 86 p., https://doi.org/10.2172/1408777.

\section{Additional Publications}

\section{Raptor Behavior, Ecology, and Distribution}

Bedrosian, G., Watson, J.W., Steenhof, K., Kochert, M.N., Preston, C.R., Woodbridge, B., Williams, G.E., Keller, K.R., and Crandall, R.H., 2017, Spatial and temporal patterns in golden eagle diets in the Western United States, with implications for conservation planning: Journal of Raptor Research, v. 51, no. 3, p. 347-367, https://doi.org/10.3356/JRR-16-38.1.

Braham, M., Miller, T., Duerr, A.E., Lanzone, M., Fesnock, A., LaPre, L., Driscoll, D., and Katzner, T., 2015, Home in the heat-Dramatic seasonal variation in home range of desert golden eagles informs management for renewable energy development: Biological Conservation, v. 186, p. 225-232, https://doi.org/10.1016/j.biocon.2015.03.020.

Carlile, J.D., Sanders, L.E., Chalfoun, A.D., and Gerow, K.G., 2018, Raptor nest-site use in relation to the proximity of coalbed methane development: Animal Biodiversity and Conservation, v. 41, no. 2, p. 227-243, https://doi.org/10.32800/ abc.2018.41.0227.

Longshore, K.M., Esque, T.C., Nussear, K.E., Johnson, D., Simes, M., and Inman, R.D., 2017, An assessment of food habits, prey availability, and nesting success of golden eagles within the Desert Renewable Energy Conservation Plan Area: California Energy Commission, CEC-500-2017-003, prepared by U.S. Geological Survey under contract no. 500-12-17, 57 p., https://pubs.er.usgs.gov/publication/70190366.

Mallon, J.M., Bildstein, K.L., and Katzner, T.E., 2016, In-flight turbulence benefits soaring birds: The Auk, v. 133, no. 1, p. 79-85, https://doi.org/10.1642/auk-15-114.1.

Mitchell, N.R., 2017, Assessment of golden eagles in the southern Great Plains and Trans Pecos regions: Lubbock, Texas Tech University, M.S. thesis, 96 p., http://hdl.handle.net/2346/72725.

Poessel, S.A., Bloom, P.H., Braham, M.A., and Katzner, T.E., 2016, Age- and season-specific variation in local and long-distance movement behavior of golden eagles: European Journal of Wildlife Research, v. 62, no. 4, p. 377-393, https://doi.org/10.1007/s10344-016-1010-4. 
Simes, M., Johnson, D., Streit, J., Longshore, K., Nussear, K.E., and Esque, T.C., 2017, Common raven (C orvus corax) kleptoparasitism at golden eagle (Aquila chrysaetos) nest in southern Nevada: Wilson Journal of Ornithology, v. 129, no. 1, p. 195-198, https://doi.org/10.1676/1559-4491-129.1.195.

Simes, M.T., Longshore, K.M., Nussear, K.E., Beatty, G.L., Brown, D.E., and Esque, T.C., 2015, Black-tailed and white-tailed jackrabbits in the American West-History, ecology, ecological significance, and survey methods: Western North American Naturalist, v. 75, no. 4, p. 491-519, https://doi.org/10.3398/064.075.0406.

Tack, J.D., and Fedy, B.C., 2015, Landscapes for energy and wildlife - Conservation prioritization for golden eagles across large spatial scales: PLOS ONE, v. 10, no. 8, e0134781, 18 p., https://doi.org/10.1371/journal.pone.0134781.

Tack, J.D., Noon, B.R., Bowen, Z.H., Strybos, L., and Fedy, B.C., 2017, No substitute for survival—Perturbation analyses using a golden eagle population model reveals limits to managing for take: Journal of Raptor Research, v. 51, no. 3, p. 258-272, https://doi.org/10.3356/JRR-16-32.1.

U.S. Geological Survey, 2016, Golden eagle flight [Stephen M. Wessells, producer, director, videographer]: U.S. Geological Survey video, 00:03:19, https://www.usgs.gov/media/videos/golden-eagle-flight.

U.S. Geological Survey, 2016, Mojave golden eagles [Stephen M. Wessells, producer; Justin Louis, narrator]: U.S. Geological Survey video, 00:05:13, posted May 31, 2016, https:/www.youtube.com/watch?v=6s-e_utRMDY.

\section{Survey, Monitoring, and Siting Tools}

Jachowski, D.S., Katzner, T., Rodrigue, J.L., and Ford, W.M., 2015, Monitoring landscape-level distribution and migration phenology of raptors using a volunteer camera-trap network: Wildlife Society Bulletin, v. 39, no. 3, p. 553-563, https://doi.org/10.1002/wsb.571.

New, L., Bjerre, E., Millsap, B., Otto, M.C., and Runge, M.C., 2015, A collision risk model to predict avian fatalities at wind facilities_-An example using golden eagles, Aquila chrysaetos: PLOS ONE, v. 10, no. 7, e0130978, 12 p., https://doi.org/10.1371/journal.pone.0130978.

Skipper, B.R., Boal, C.W., Tsai, J.-S., and Fuller, M.R., 2017, Assessment of frequency and duration of point counts when surveying for golden eagle presence: Wildlife Society Bulletin, v. 41, no. 2, p. 212-223, https://doi.org/10.1002/wsb.770.

Wiens, J.D., Kolar, P.S., and Katzner, T.E., 2018, Energy Research and Development Division final project report-Golden eagle monitoring plan for the Desert Renewable Energy Conservation Plan: California Energy Commission, CEC-500-2018-008, prepared by U.S. Geological Survey under contract no. 500-12-007, 98 p., https://pubs.er.usgs.gov/publication/70196435.

Wiens, J.D., Schumaker, N.H., Inman, R.D., Esque, T.C., Longshore, K.M., and Nussear, K.E., 2017, Spatial demographic models to inform conservation planning of golden eagles in renewable energy landscapes: Journal of Raptor Research, v. 51, no. 3, p. 234-257, https://doi.org/10.3356/JRR-16-77.1.

\section{California Condor Movement and Space Use}

Rivers, J.W., Johnson, J.M., Haig, S.M., Schwarz, C.J., Burnett, L.J., Brandt, J., George, D., and Grantham, J., 2014, An analysis of monthly home range size in the critically endangered California condor G ymnogyps californianus: Bird Conservation International, v. 24, no. 4, p. 492-504, https://doi.org/10.1017/s0959270913000592.

Rivers, J.W., Johnson, J.M., Haig, S.M., Schwarz, C.J., Burnett, L.J., Brandt, J., George, D., and Grantham, J., 2014, An analysis of monthly home range size in the critically endangered California condor Gymnogyps californianus-CORRIGENDUM: Bird Conservation International, v. 25, no. 2, p. 258, https://doi.org/10.1017/s0959270915000039.

Tracey, J.A., Sheppard, J., Zhu, J., Wei, F., Swaisgood, R.R., Fisher, R.N., and Sueur, C., 2014, Movement-based estimation and visualization of space use in 3D for wildlife ecology and conservation: PLOS ONE, v. 9, no. 7, e101205, 15 p., https://doi.org/10.1371/journal.pone.0101205. 


\section{Grassland Birds and Waterbirds and Land-Based Energy}

Birds can be indirectly affected by habitat alteration from conventional and renewable energy development (Shaffer and Buhl, 2015), and populations are also at risk from other anthropogenic factors such as grassland conversion to agriculture, environmental contaminants, and climate change. Energy development can degrade habitat quality for breeding birds by introducing noise, movement of large vehicles along new roads, encroachment of invasive plants, and changes in predator populations. USGS scientists are studying the effects of a variety of stressors on breeding birds in the Great Plains, Intermountain West, and other regions of the United States to assist State and Federal land managers in the management of bird populations and the energy industry in siting and managing projects with a better understanding of potential risks to vulnerable bird populations.

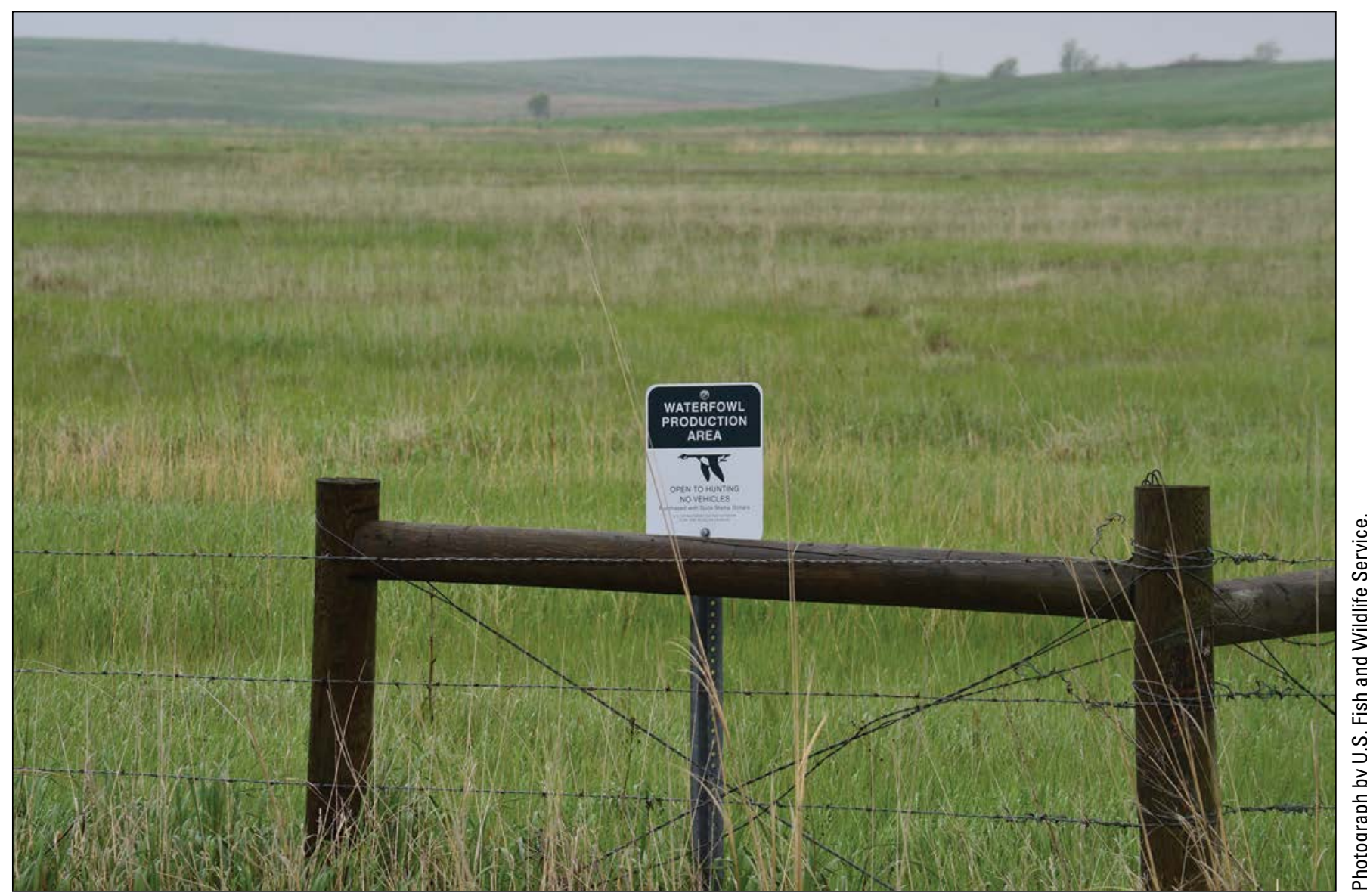

Waterfowl Production Area, Long Lake National Wildlife Refuge in North Dakota.

\section{Northern Prairie and Great Plains}

\section{Prairie Grouse Lek Dynamics in} Landscapes Near Wind Energy Facilities in North Dakota and South Dakota

The northern Great Plains has high potential for wind energy development, particularly along the Missouri Plateau in North and South Dakota. The area also provides important grassland breeding habitat for sharp-tailed grouse and greater prairie-chicken. From 2003 to 2014, the USGS conducted spring lek counts of prairie grouse in study areas with and without wind turbines as part of a larger study to assess the impacts of wind energy development on grassland birds.

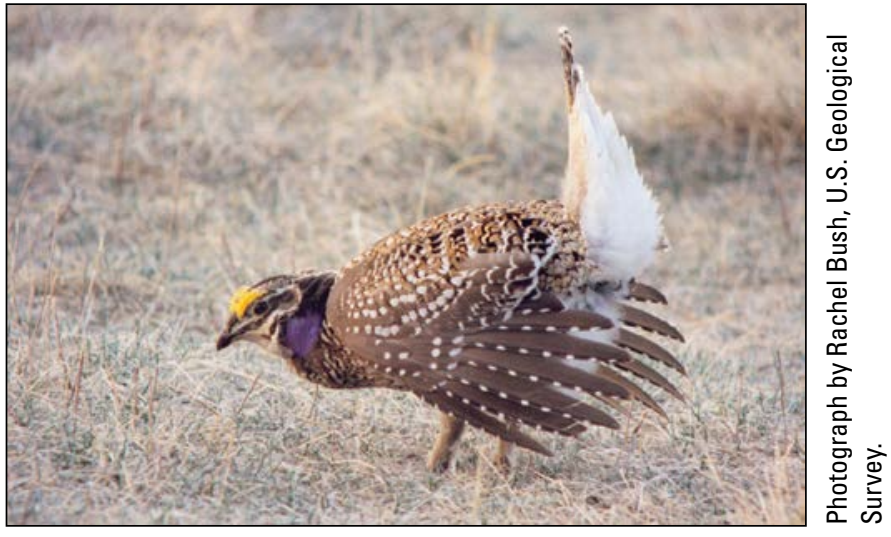

Male sharp-tailed grouse during spring breeding season. 
Additional data were collected by the U.S. Forest Service; the North Dakota Game and Fish Department; South Dakota Game, Fish, and Parks; and Western EcoSystems Technology, Inc. Analyses are being performed to determine correlations between lek parameters (that is, lek densities and mean males per lek) and landscape features.

\section{Contacts}

Wesley E. Newton, USGS Northern Prairie Wildlife Research Center, wnewton@usgs.gov, (701) 253-5523

Jill A. Shaffer, USGS Northern Prairie Wildlife Research Center, jshaffer@usgs.gov, (701) 253-5547

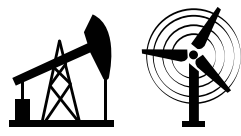

\section{Lesser Prairie-Chicken Population and Habitat Ecology}

The lesser prairie-chicken currently occupies a range that includes parts of Colorado, Kansas, New Mexico, Oklahoma, and Texas. This species has experienced population declines due to both direct and indirect habitat loss, including conversion of native rangeland to cropland and disturbance from energy development. Studies by the USGS and collaborators predict habitat suitability for lesser prairie-chicken leks by exploring lesser prairie-chicken occurrence in relation to landscape characteristics, drought, and anthropogenic effects, such as distance to active wells, roads, highways, transmission lines, and tall structures. USGS scientists investigated the effects of proximity to anthropogenic structures on home range and nest placement to better understand the spatial ecology of lesser prairie-chicken and the influences of habitat change on population trends. Habitat suitability models, combined with other landscape information, form the basis of a habitat assessment tool that can be used to guide siting of development projects and targeting of areas for conservation.

\section{Contacts}

Dave Haukos, USGS Kansas Cooperative Fish and Wildlife Research Unit, dhaukos@ksu.edu, (785) 532-5761

Clint Boal, USGS Texas Cooperative Fish and Wildlife Research Unit, cboal@usgs.gov, (806) 742-2851

\section{Publications}

Cummings, J.W., Converse, S.J., Moore, C.T., Smith, D.R., Nichols, C.T., Allan, N.L., and O'Meilia, C.M., 2017, A projection of lesser prairie-chicken (Tympanuchus pallidicinctus) populations range-wide: U.S. Geological Survey Open-File Report 2017-1071, 60 p., https://doi.org/10.3133/ofr20171071.

Earl, J.E., Fuhlendorf, S.D., Haukos, D., Tanner, A.M., Elmore, D., and Carleton., S.A., 2016, Characteristics of lesser prairiechicken (Tympanuchus pallidicinctus) long-distance movements across their distribution: Ecosphere, v. 7, no. 8, e01441, 13 p., https://doi.org/10.1002/ecs2.1441.

Grisham, B.A., Godar, A.J., Boal, C.W., and Haukos, D.A., 2016, Interactive effects between nest microclimate and nest vegetation structure confirm microclimate thresholds for lesser prairie-chicken nest survival: The Condor, v. 118, no. 4, p. 728-746, https://doi.org/10.1650/CONDOR-16-38.1.

Haukos, D.A., and Boal, C.W., eds., 2016, Ecology and conservation of lesser prairie-chickens: Boca Raton, Fla., CRC Press, v. $48,371 \mathrm{p}$.

Jarnevich, C.S., Holcombe, T.R., Grisham, B.A., Timmer, J., Boal, C.W., Butler, M.J., Pitman, J., Kyle, S.C., Klute, D., Beauprez, G.M., Janus, A., and Van Pelt, W.E., 2016, Assessing range-wide habitat suitability for the lesser prairie-chicken: Avian Conservation and Ecology, v. 11, no. 1, 18 p., https://doi.org/10.5751/ace-00807-110102.

Lautenbach, J.M., Haukos, D.A., Sullins, D.S., Hagen, C.A., Lautenbach, J.D., Pitman, J.C., Plumb, R.T., Robinson, S.G., and Kraft, J.D., 2018, Factors influencing nesting ecology of lesser prairie-chickens: Journal of Wildlife Management: v. 83, no. 1, p. 205-215, https://doi.org/10.1002/jwmg.21582.

Lautenbach, J.M., Plumb, R.T., Robinson, S.G., Hagen, C.A., Haukos, D.A., and Pitman, J.C., 2017, Lesser prairiechicken avoidance of trees in a grassland landscape: Rangeland Ecology and Management, v. 70, no. 1, p. 78-86, https://doi.org/10.1016/j.rama.2016.07.008.

Meyers, A.R., Carleton, S.A., Gould, W.R., Nichols, C.T., Haukos, D.A., and Hagen, C.A., 2018, Temporal variation in breeding season survival and cause-specific mortality of lesser prairie-chickens: Journal of Fish and Wildlife Management, v. 9, no. 2, p. 507-518, https://doi.org/10.3996/112016-JFWM-081.

Plumb, R.T., Lautenbach, J.M., Robinson, S.G., Haukos, D.A., Winder, V.L., Hagen, C.A., Sullins, D.S., Pitman, J.C., and Dahlgren, D.K., 2018, Lesser prairie-chicken space use in relation to anthropogenic structures: Journal of Wildlife Management: v. 83, no. 1, p. 216-230, https://doi.org/10.1002/jwmg.21561. 
Robinson, S.G., Haukos, D.A., Plumb, R.T., Lautenbach, J.M., Sullins, D.S., Kraft, J.D., Lautenbach, J.D., Hagen, C.A., and Pitman, J.C., 2018, Nonbreeding home-range size and survival of lesser prairie-chickens: Journal of Wildlife Management, v. 82, no. 2, p. 413-423, https://doi.org/10.1002/jwmg.21390.

Ross, B.E., Haukos, D.A., Hagen, C.A., and Pitman, J., 2018, Combining multiple sources of data to inform conservation of lesser prairie-chicken populations: The Auk, v. 135, no. 2, p. 228-239, https://doi.org/10.1642/AUK-17-113.1.

Ross, B.E., Sullins, D.S., and Haukos, D.A., 2019, Using an individual-based model to assess common biases in lekbased count data to estimate population trajectories of lesser prairie-chickens: PLOS ONE, v. 14, no. 5, e0217172, 17 p., https://doi.org/10.1371/journal.pone.0217172.

Spencer, D., Haukos, D., Hagen, C., Daniels, M., and Goodin, D., 2017, Conservation Reserve Program mitigates grassland loss in the lesser prairie-chicken range of Kansas: Global Ecology and Conservation, v. 9, p. 21-38, https://doi.org/10.1016/j.gecco.2016.11.004.

Winder, V.L., Carrlson, K.M., Gregory, A.J., Hagen, C.A., Haukos, D.A., Kesler, D.C., Larsson, L.C., Matthews, T.W., McNew, L.B., Patten, M.A., Pitman, J.C., Powell, L.A., Smith, J.A., Thompson, T., Wolfe, D.H., and Sandercock, B.K., 2015, Factors affecting female space use in ten populations of prairie chickens: Ecosphere, v. 6, no. 9, p. 1-17, https://doi.org/10.1890/ ES14-00536.1.

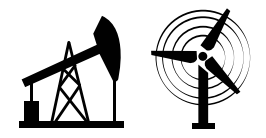

\section{Estimating Offsets for Avian Displacement Effects of Anthropogenic Activities}

of breeding grassland birds and waterfowl. To quantify and compensate for this loss in value of avian breeding habitat, USGS and USFWS scientists developed a method to determine the amount of habitat needed to provide equivalent biological value for avifauna displaced by energy and transportation infrastructure, on the basis of five metrics: impact distance, impact area, preimpact density, percent displacement, and offset density. Recent studies demonstrated the applicability of the avian-impact offset method, using examples for wind and oil infrastructure. Scientists also developed a worksheet that informs potential users how to apply the method to specific developments and a framework for decision-support tools aimed at achieving landscape-level conservation decisions for biodiversity offsetting. These tools can be applied in situations where compensatory mitigation for impacted habitat is desirable or required.

\section{Contact}

Jill A. Shaffer, USGS Northern Prairie Wildlife Research Center, jshaffer@usgs.gov, (701) 253-5547

\section{Publications}

Shaffer, J.A., and Buhl, D.A., 2015, Effects of wind-energy facilities on breeding grassland bird distributions: Conservation Biology, v. 30, no. 1, p. 59-71, https://doi.org/10.1111/cobi.12569.

Shaffer, J.A., Loesch, C.R., and Buhl, D.A., 2019, Estimating offsets for avian displacement effects of anthropogenic impacts: Ecological Applications, early view posted July 26, 2019, 46 p., https://doi.org/10.1002/eap.1983.

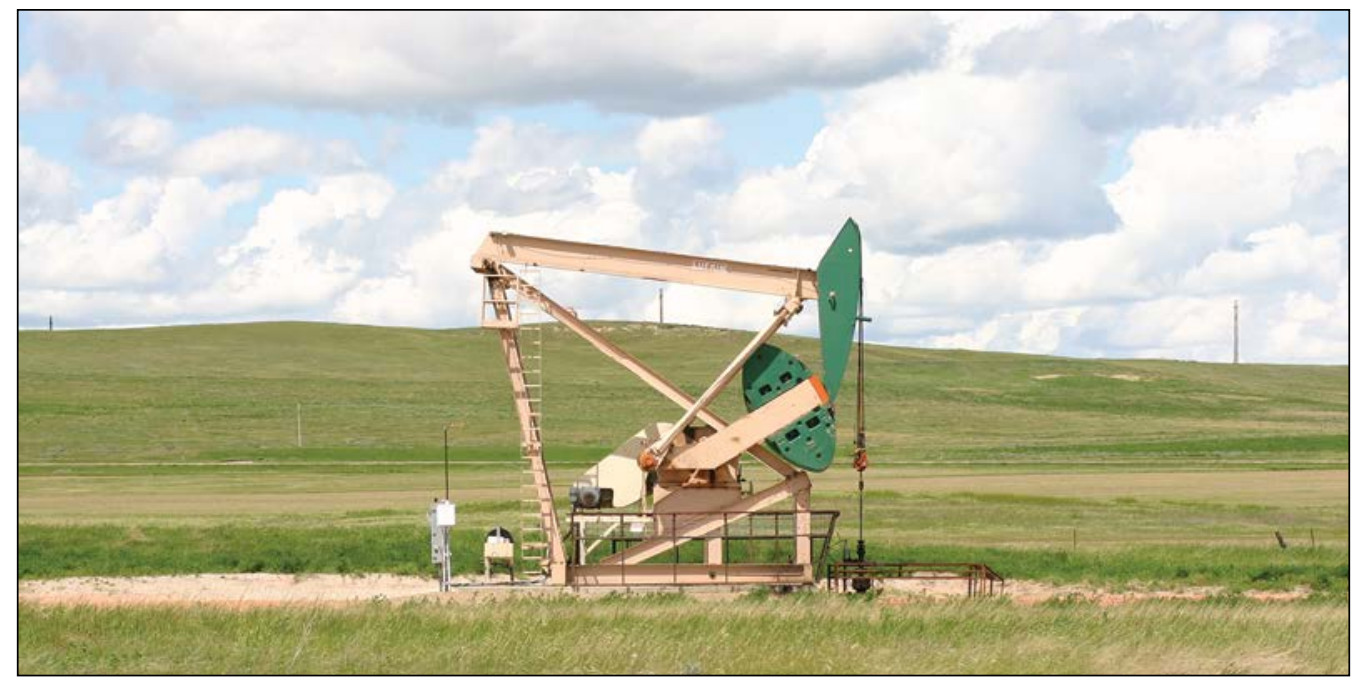

Researchers have documented the behavioral avoidance of some species of grassland birds to oil infrastructure, such as to this well pump jack in Fallon County, Montana. 


\section{Assessing Potential Disturbance and Threats Posed by Energy Development for Aransas-Wood Buffalo Whooping Cranes}

Endangered whooping cranes of the AransasWood Buffalo population are encountering increased human activity. The USGS, in partnership with the USFWS, the Canadian Wildlife Service, and Parks Canada, is engaged in studies to determine how three energy extraction activities constitute potential risk for species recovery. Oil and gas extraction has expanded at Aransas National Wildlife Refuge, located in southeast Texas, and potential disturbance and other impacts are not known. Cranes also migrate through Canada's oil sands mining region twice annually, and the consequences of migrating through mining areas have not been determined. Finally, uncertainty persists regarding the potential threat of wind energy infrastructure. Identification and assessment of risk factors can allow development of conservation and management programs targeted to minimize risk for all energy extraction activities.

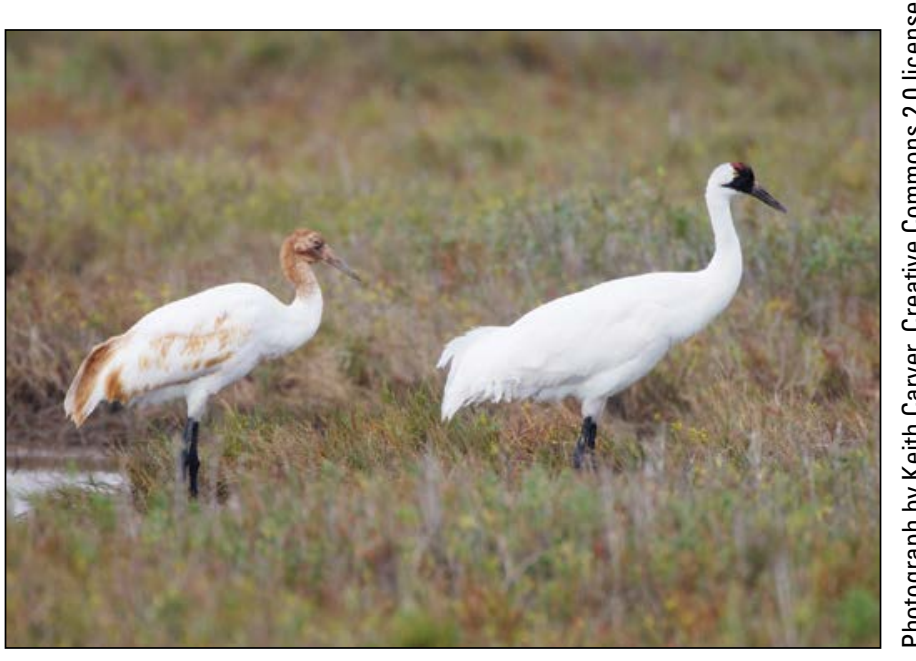

Adult and juvenile whooping cranes, Aransas National Wildlife Refuge, Rockport, Texas.

\section{Contact}

Aaron Pearse, USGS Northern Prairie Wildlife Research Center, apearse@usgs.gov, (701) 253-5509

\section{LId $\mid \begin{aligned} & \text { 26. Population Dynamics of Piping Plovers and Least Terns in Response to Missouri River } \\ & \text { Management }\end{aligned}$}

The USGS is leading a multiagency regional study to understand population dynamics of piping plovers and least terns on the Missouri River. These federally listed species nest on riverine sandbars and reservoir shorelines of the Missouri River, and the availability and quality of their habitat change in response to climate and watermanagement activities. The U.S. Army Corps of Engineers (USACE) manages the Missouri River to benefit a wide variety of uses, including hydropower, recreation, water supply, navigation, flood control, and fish and wildlife. The USACE is planning to create suitable piping plover and least tern breeding habitat along the Missouri River as part of the Missouri River Recovery Program. The USGS-led study is providing population demographic and dispersal information that can inform decisions about management,

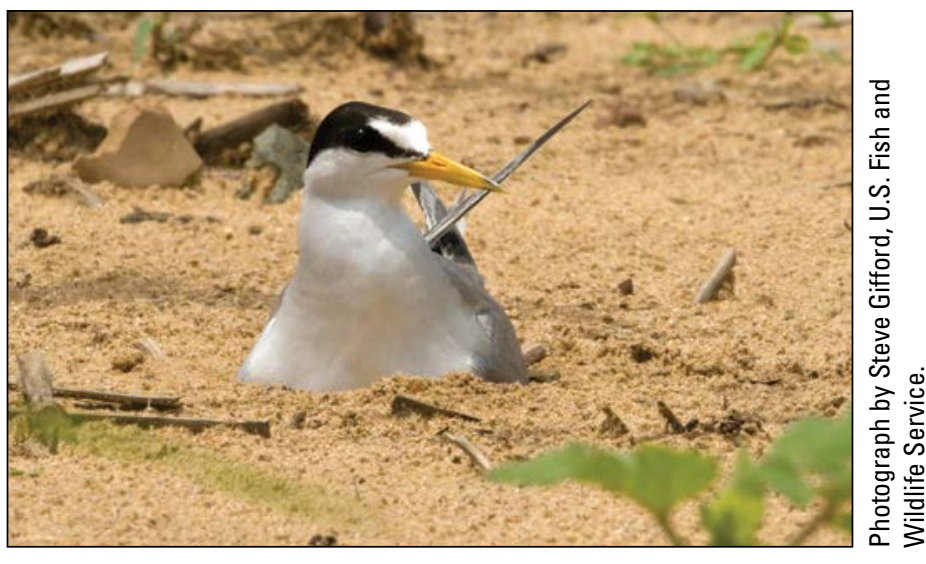

Least tern. conservation, and recovery of these species and overall management of the Missouri River.

\section{Contact}

Michael J. Anteau, USGS Northern Prairie Wildlife Research Center, manteau@usgs.gov, (701) 253-5507

\section{Publications}

Roche, E.A., Shafter, T.L., Dovichin, C.M., Sherfy, M.H., Anteau, M.J., and Wiltermuth, M.T., 2016, Synchrony of piping plover breeding populations in the U.S. Northern Great Plains: The Condor, v. 118, no. 3, p. 558-570, https://doi.org/10.1650/ CONDOR-15-195.1.

Toy, D.L., Roche, E.A., and Dovichin, C.M., 2017, Small high-definition video cameras as a tool to resight uniquely marked interior least terns (Sternula antillarum athalassos): Waterbirds, v. 40, no. 2, p. 180-186, https://doi.org/10.1675/063.040.0211. 


\section{Intermountain West}

\section{Potential Impacts of Future Oil and Gas Development and Climate Change on Greater Sage-Grouse in Southwest Wyoming}

Oil and gas development and climate change have the potential to affect greater sage-grouse, but little is known about the influences these changes may have on population trajectories. USGS scientists used spatially explicit and individual-based models to simulate greater sage-grouse responses to changing development infrastructure by using a range of expected development intensities and restrictions. Greater sage-grouse responses to climate-induced vegetation changes of future climate scenarios were also simulated to evaluate the influence of climate on greater sage-grouse abundance and distribution. Results indicate that increases in oil and gas development and reduced precipitation could decrease greater sage-grouse abundance and alter distributions through time. Although mean annual changes were small, their accrual through time resulted in discernible population changes, particularly when oil and gas development and climate change occurred together. Results underscore the need to spatially evaluate multiple causes of incremental change to plan landscapes that include human activities and wildlife.

\section{Contacts}

Cameron L. Aldridge, Colorado State University, in cooperation with USGS Fort Collins Science Center, aldridgec@usgs.gov, (970) 226-9433

Julie A. Heinrichs, Colorado State University, in cooperation with USGS Fort Collins Science Center, jheinrichs@usgs.gov, (970) 226-9149

\section{Publication}

Heinrichs, J.A., O’Donnell, M.S., Aldridge, C.L., Garman, S.L., and Homer, C.G., 2019, Influences of potential oil and gas development and future climate on sage-grouse declines and redistribution: Ecological Applications, early view posted July 16, 2019, e01912, 16 p., https://doi.org/10.1002/eap.1912.

\section{Effects of Energy Development on Greater Sage-Grouse and Their Predators}

An increasing human footprint across ecosystems in the American West often results in disturbance to native vegetation and related changes that are favorable to generalist predator species, such as ravens. A large portion of the Great Basin supports proposed and recently developed energy transmission lines and renewable energy sources, such as geothermal energy and wind. Further energy infrastructure development could continue to fragment the contiguous sagebrush-steppe ecosystems that provide seasonal habitat for greater sage-grouse populations. The USGS, in collaboration with other Federal and State agencies and private industry, is working to understand how energy development and habitat loss influence predatorprey interactions between ravens and nesting greater sage-grouse. This science can provide resource managers with information and tools to help develop guidelines for future energy-related projects that minimize adverse impacts on greater sage-grouse populations.

\section{Contacts}

Michael Casazza, USGS Western Ecological Research Center, mike_casazza@usgs.gov, (530) 669-5075

Peter Coates, USGS Western Ecological Research Center, pcoates@usgs.gov, (530) 669-5073

\section{Publications}

Coates, P.S., Brussee, B.E., Ricca, M.A., Dudko, J.E., Prochazka, B.G., Espinosa, S.P., Casazza, M.L., and Delehanty, D.J., 2017, Greater sage-grouse (Centrocercus urophasianus) nesting and brood-rearing microhabitat in Nevada and California-Spatial variation in selection and survival patterns: U.S. Geological Survey Open-File Report 2017-1087, 79 p., https://doi.org/10.3133/ofr20171087.

Coates, P.S., Casazza, M.L., Ricca, M.A., Brussee, B.E., Blomberg, E.J., Gustafson, K.B., Overton, C.T., Davis, D.M., Niell, L.E., Espinosa, S.P., Gardner, S.C., and Delehanty, D.J., 2015, Integrating spatially explicit indices of abundance and habitat quality-An applied example for greater sage-grouse management: Journal of Applied Ecology, v. 53, no. 1, p. 83-95, https://doi.org/10.1111/1365-2664.12558.

Howe, K.B., and Coates, P.S., 2015, Observations of territorial breeding common ravens caching eggs of greater sage-grouse: Journal of Fish and Wildlife Management, v. 6, no. 1, p. 187-190, https://doi.org/10.3996/042014-jfwm-030. 
Mathews, S.R., Coates, P.S., Prochazka, B.G., Ricca, M.A., Meyerpeter, M.B., Espinosa, S.P., Lisius, S., Gardner, S.C., and Delehanty, D.J., 2018, An integrated population model for greater sage-grouse (Centrocercus urophasianus) in the Bi-State Distinct Population Segment, California and Nevada, 2003-17: U.S. Geological Survey Open-File Report 2018-1177, 89 p., https://doi.org/10.3133/ofr20181177.

O’Neil, S.T., Coates, P.S., Brussee, B.E., Jackson, P.J., Howe, K.B., Moser, A.M., Foster, L.J., and Delehanty, D.J., 2018, Broadscale occurrence of a subsidized avian predator-Reducing impacts of ravens on sage-grouse and other sensitive prey: Journal of Applied Ecology, v. 55, no. 6, p. 2641-2652, https://doi.org/10.1111/1365-2664.13249.

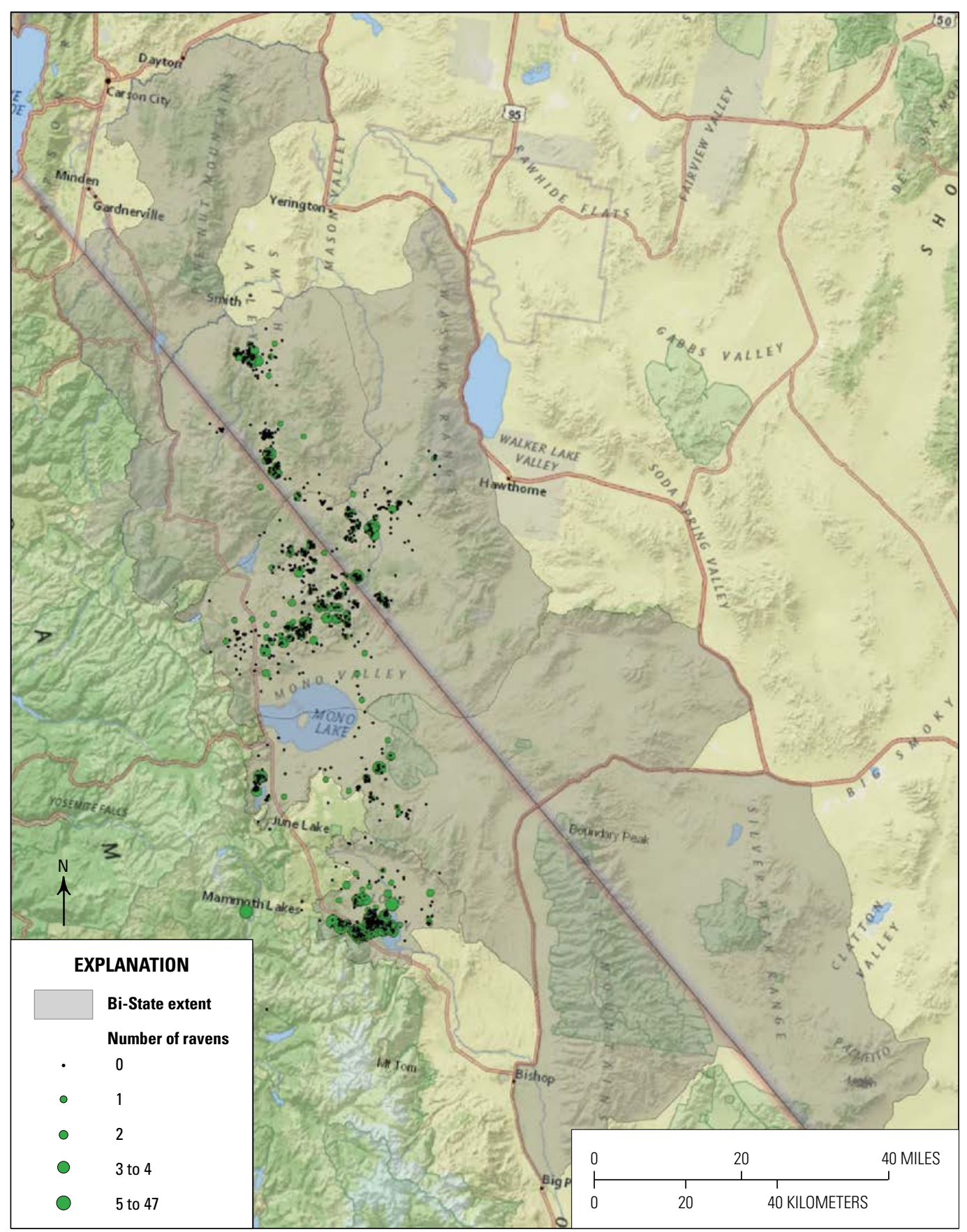

Survey locations and corresponding number of raven detections from March to August across the Bi-State Distinct Population Segment study area, California and Nevada, 2015-17 (modified from Mathews and others, 2018). 


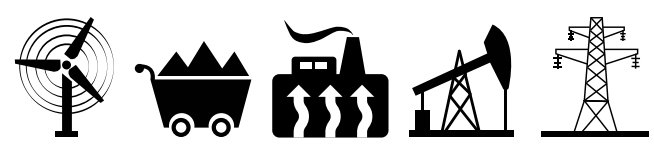

\section{Implications of Anthropogenic Activities on Greater Sage-Grouse Populations in Nevada}

The USGS has initiated a study at nine sites across Nevada to answer questions related to short- and long-term effects on greater sage-grouse habitat selection, population vital rates, and movement patterns from disturbance caused by wind turbines, gold mining, geothermal energy production, hydraulic fracturing for oil, and transmission line development. This information can help managers develop guidelines that minimize the negative effects of these activities on greater sage-grouse and their associated habitat.

\section{Contact}

Peter Coates, USGS Western Ecological Research Center, pcoates@usgs.gov, (530) 669-5073

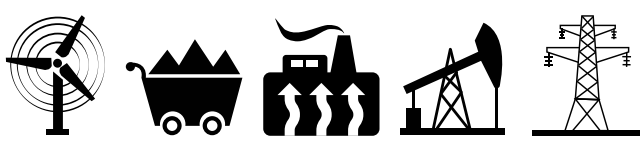

\section{Influence of Energy Development and Climatic Variability on Sagebrush Songbirds}

Populations of three species of songbirds (Brewer's sparrow, sagebrush sparrow, sage thrasher) that nest almost exclusively within North American sagebrush habitats have been declining, at least partly due to habitat changes on breeding grounds. The USGS has partnered with the Wyoming Landscape Conservation Initiative (WLCI), the USFWS, the Western Association of Fish and Wildlife Agencies, Wyoming Wildlife Foundation, and the Wyoming Game and Fish Department to evaluate the influence of energy development and a changing climate on species of concern in the sagebrush ecosystem. This project leverages a large, multiyear dataset of sagebrush songbird nests and remotely-sensed weather data to investigate the joint influence of climatic conditions and energy development on the reproductive success of sagebrush songbirds in western Wyoming. Ongoing field efforts continue to document the nesting success of sensitive species in relation to natural gas development and climatic conditions. This information can be used to update Wyoming's Comprehensive Wildlife Conservation Strategy and the Wyoming State Wildlife Action Plan, inform climate vulnerability assessments, and address informational needs of the multiagency Sagebrush Conservation Initiative.

\section{Contact}

Anna D. Chalfoun, USGS Wyoming Cooperative Fish and Wildlife Research Unit, achalfoun@usgs.gov, (307) 766-6966

\section{Publication}

Sanders, L.E., and Chalfoun, A.D., 2019, Mechanisms underlying increased nest predation in natural gas fields-A test of the mesopredator release hypothesis: Ecosphere, v. 10, no. 5, e02738, 17 p., https://doi.org/10.1002/ecs2.2738. 


\section{Alaska}

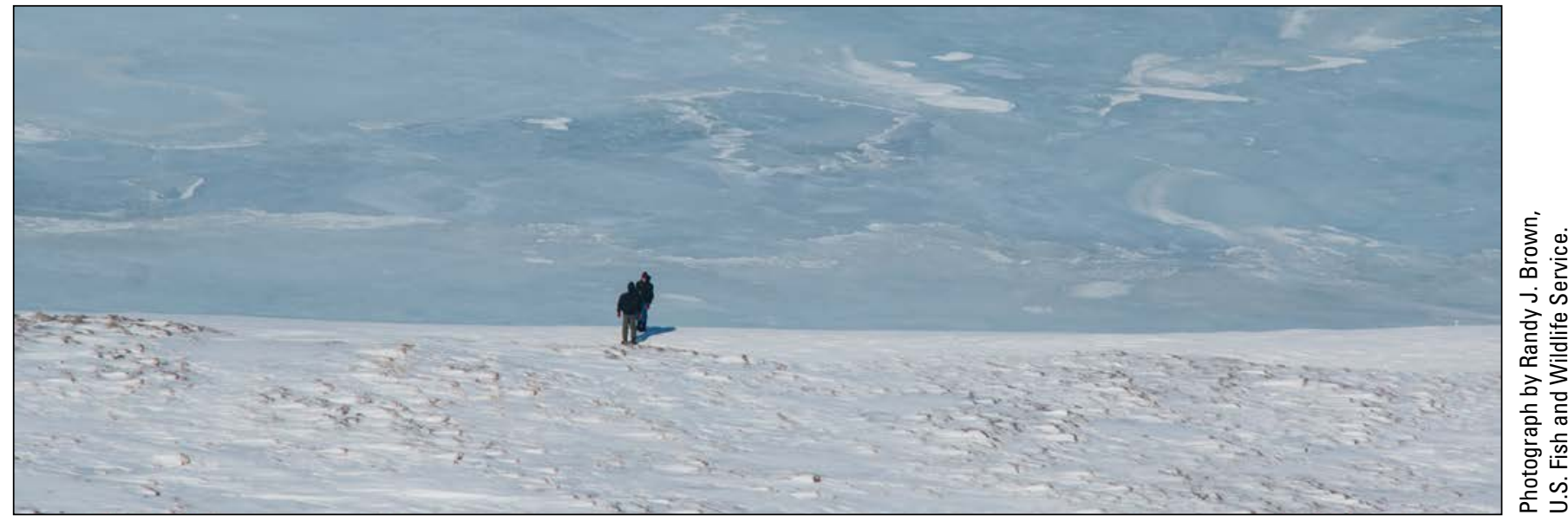

Scientists standing on the shore of the Canning River, Alaska.

\section{Distribution and Abundance of Waterbirds on the North Slope of Alaska}

USGS and USFWS scientists assessed the distribution, abundance, population trends, and important habitat areas for 20 waterbird species breeding on the Arctic Coastal Plain, Alaska, including portions of the National Petroleum Reserve-Alaska (NPR-A) and the Arctic National Wildlife Refuge, 1002 area. The authors reanalyzed USFWS aerial survey data collected from 1992 to 2016 to estimate and map population densities, trends, and important habitat areas for waterbird species across the study area. Fine-resolution maps were produced to assist managers tasked with leasing land for oil and gas exploration and researchers looking to explore mechanisms underlying areas of population change.

\section{Contact}

Courtney Amundson, USGS Alaska Science Center, camundson@usgs.gov, (907) 786-7062

\section{Publication}

Amundson, C.L., Flint, P.L., Stehn, R.A., Platte, R.M., Wilson, H.M., Larned, W.W., and Fischer, J.B., 2019, Spatio-temporal population change of Arctic-breeding waterbirds on the Arctic Coastal Plain of Alaska: Avian Conservation and Ecology: v. 14, no. 1, article no. 18, 19 p., https://doi.org/10.5751/ACE-01383-140118.

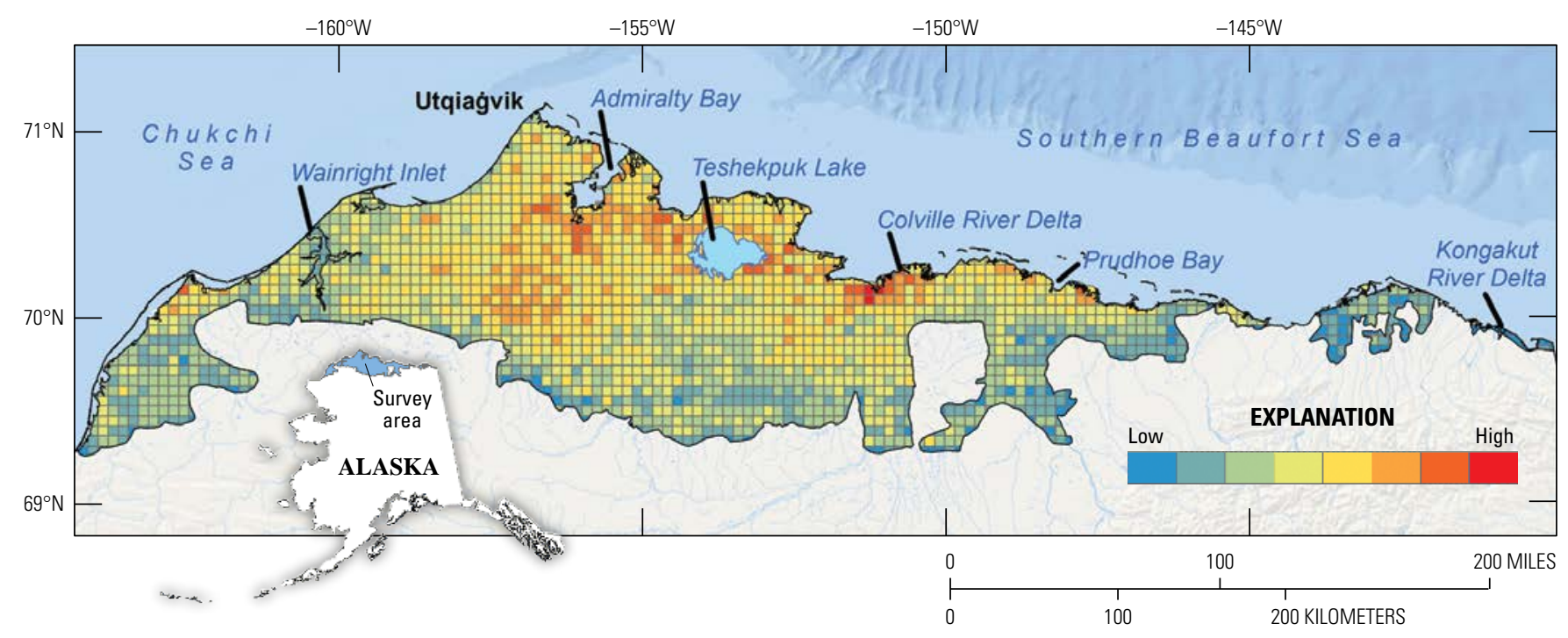

Relative importance of 36-square-kilometer cells to 20 waterbird species observed during the Arctic Coastal Plain Breeding Waterfowl Survey, Alaska, 1992-2016. Image modified from Amundson and others (2019), Creative Commons 4.0 license. 


\section{Movement and Habitat Use of Loons on the North Slope of Alaska}

The distribution, abundance, and nesting locations of three loon species that breed on the North Slope of Alaska are being studied in relation to future expansion of oil and gas leasing and development in onshore and offshore areas in the region. Management guidelines within the NPR-A exist to protect breeding and foraging areas of yellow-billed loons due to their small population size in the Arctic, but there are no such guidelines for two other species - red-throated loons and Pacific loons-because of limited information on their habitat use patterns. USGS scientists are using multiple years of satellite telemetry data to compare differences in the habitat use of these three loon species on the North Slope and to evaluate the extent to which current oil and gas management guidelines for yellow-billed loons correspond with movements of all three loon species in the NPR-A. This project can inform the BLM, BOEM, and industry of habitat areas used by loons and if breeding territories match current management guidelines for restricted industrial development within certain buffer zones around nesting areas.

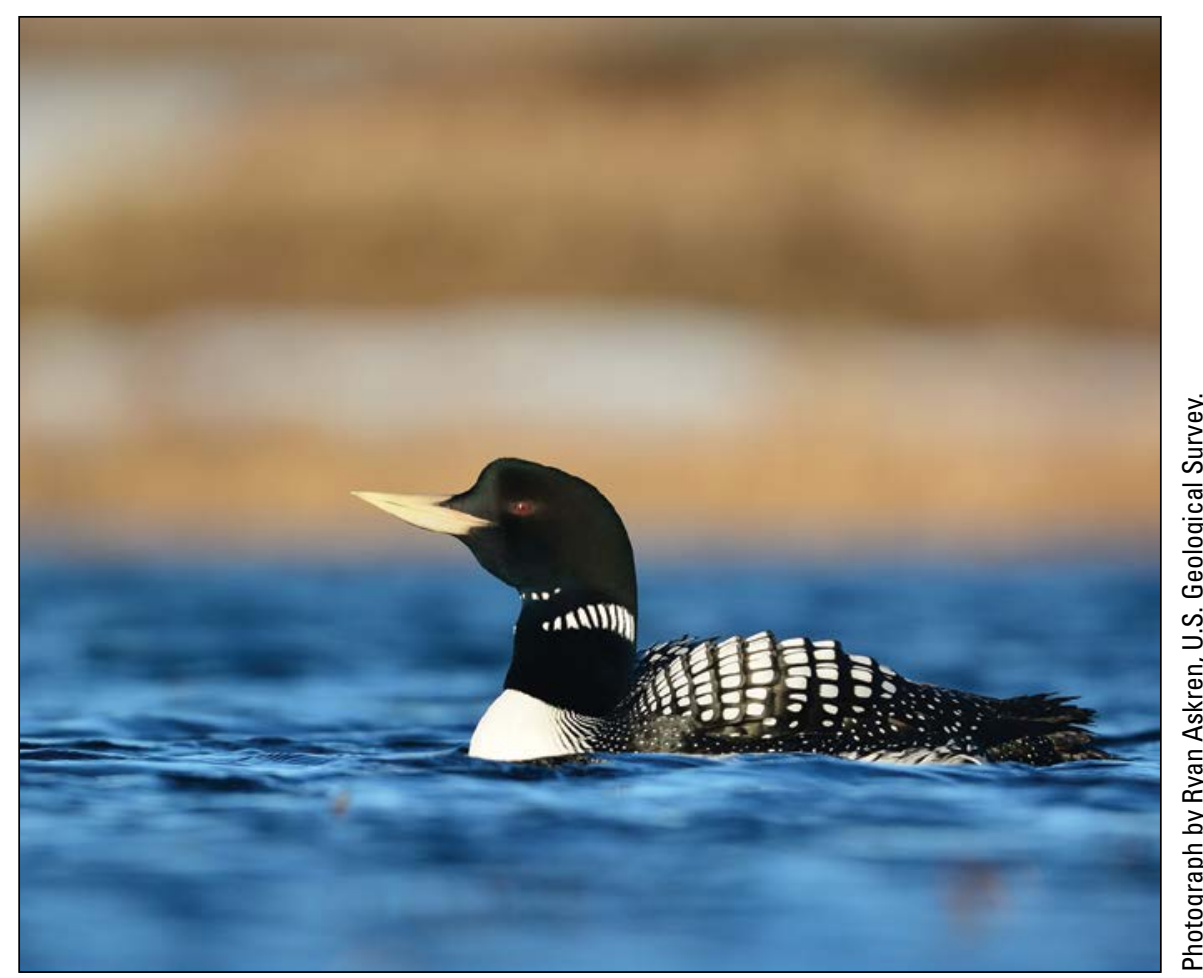

Yellow-billed loon in a small lake on the Arctic Coastal Plain.

\section{Contact}

John M. Pearce, USGS Alaska Science Center, jpearce@usgs.gov, (907) 786-7094

\section{Breeding Territory Retention in Pacific and Yellow-Billed Loons in the National 1 Petroleum Reserve-Alaska}

USGS scientists evaluated the role of breeding success and competition on territory retention by Pacific and yellowbilled loons. Annual territory retention rates were greater than 90 percent regardless of prior nesting success in a territory. Occupied territories were also frequently visited by nonbreeding loons. Yellow-billed loon results suggest there is limited habitat in the National Petroleum Reserve-Alaska (NPR-A) for new territories, and the extent of breeding habitat in northern Alaska may be limiting the size of the breeding population. In contrast, Pacific loons appear more able to establish new territories outside occupied territories. Study results indicate that territory retention and apparent survival rates for both loon species are high, and chick production does not affect loon territory retention. This information may be useful for guiding future oil and gas development near yellow-billed loon nesting areas.

\section{Contact}

John M. Pearce, USGS Alaska Science Center, jpearce@usgs.gov, (907) 786-7094 


\section{Additional Publications}

\section{Greater Sage-Grouse}

Carter, S.K., Manier, D.J., Arkle, R.S., Johnston, A.N., Phillips, S.L., Hanser, S.E., and Bowen, Z.H., 2018, Annotated bibliography of scientific research on greater sage-grouse published since January 2015: U.S. Geological Survey Open-File Report 2018-1008, 183 p., https://doi.org/10.3133/ofr20181008.

Green, A.W., Aldridge, C.L., and O’Donnell, M.S., 2016, Investigating impacts of oil and gas development on greater sagegrouse: Journal of Wildlife Management, v. 81, no. 1, p. 46-57, https://doi.org/10.1002/jwmg.21179.

Hanser, S.E., Deibert, P.A., Tull, J.C., Carr, N.B., Aldridge, C.L., Bargsten, T.D., Christiansen, T.J., Coates, P.S., Crist, M.R., Doherty, K.E., Ellsworth, E.A., Foster, L.J., Herren, V.A., Miller, K.H., Moser, A., Naeve, R.M., Prentice, K.L., Remington, T.E., Ricca, M.A., Shinneman, D.J., Truex, R.L., Wiechman, L.A., Wilson, D.C., and Bowen, Z.H., 2018, Greater sage-grouse science (2015-17) — Synthesis and potential management implications: U.S. Geological Survey Open-File Report 1028-1017, 46 p., https://doi.org/10.3133/ofr20181017.

Kirol, C.P., 2015, Mitigation effectiveness for improving nesting success of greater sage-grouse influenced by energy development: Wildlife Biology, v. 21, no. 2, p. 98-109, https://doi.org/10.2981/wlb.00002.

Manier, D.J., Bowen, Z.H., Brooks, M.L., Casazza, M.L., Coates, P.S., Deibert, P.A., Hanser, S.E., and Johnson, D.H., 2014, Conservation buffer distance estimates for greater sage-grouse-A review: U.S. Geological Survey Open-File Report 2014-1239, 14 p., https://doi.org/10.3133/ofr20141239.

\section{Sandhill Cranes}

Kirsch, E.M., Wellik, M.J., Suarez, M., Diehl, R.H., Lutes, J., Woyczik, W., Krapfl, J., and Sojda, R., 2015, Observations of sandhill cranes' (G rus canadensis) flight behavior in heavy fog: Wilson Journal of Ornithology, v. 127, no. 2, p. 281-288, https://doi.org/10.1676/wils-127-02-281-288.1.

Pearse, A.T., Brandt, D.A., and Krapu, G.L., 2016, Wintering sandhill crane exposure to wind energy development in the central and southern Great Plains, U.S.A.: The Condor, v. 118, no. 2, p. 391-401, https://doi.org/10.1650/condor-15-99.1.

\section{Wind Energy Effects}

Graff, B.J., Jenks, J.A., Stafford, J.D., Jensen, K.C., and Grovenburg, T.W., 2016, Assessing spring direct mortality to avifauna from wind energy facilities in the Dakotas: Journal of Wildlife Management, v. 80, no. 4, p. 736-745, https://doi.org/10.1002/ jwmg.1051.

Mahoney, A., and Chalfoun, A.D., 2016, Reproductive success of horned lark and McCown's longspur in relation to wind energy infrastructure: The Condor, v. 118, no. 2, p. 360-375, https://doi.org/10.1650/condor-15-25.1.

\section{Oil and Gas Effects}

Hethcoat, M.G., and Chalfoun, A.D., 2015, Energy development and avian nest survival in Wyoming, U.S.A.- - A test of a common disturbance index: Biological Conservation, v. 184, p. 327-334, https://doi.org/10.1016/j.biocon.2015.02.009.

Hethcoat, M.G., and Chalfoun, A.D., 2015, Towards a mechanistic understanding of human-induced rapid environmental change-A case study linking energy development, nest predation, and predators: Journal of Applied Ecology, v. 52, no. 6, p. 1492-1499, https://doi.org/10.1111/1365-2664.12513.

Thompson, S.J., Johnson, D.H., Nieumuth, N.D., and Ribic, C.A., 2015, Avoidance of unconventional oil wells and roads exacerbates habitat loss for grassland birds in the North American Great Plains: Biological Conservation, v. 192, p. 82-90, https://doi.org/10.1016/j.biocon.2015.08.040. 


\section{Pollinators and Bioenergy}

Conversion of grassland to cropland for biofuel production is replacing pollinator habitat with monoculture crops that have little nutritional value to bees and other native pollinators, thereby reducing forage quality of the landscape (Hellerstein and others, 2017). USGS scientists are assessing land-use changes in relation to intensification of biofuel feedstock production to better understand impacts to pollinator health, diversity, and pollination services in agricultural landscapes. Research efforts include developing conservation seed mixes and decision support tools for improving pollinator conservation.

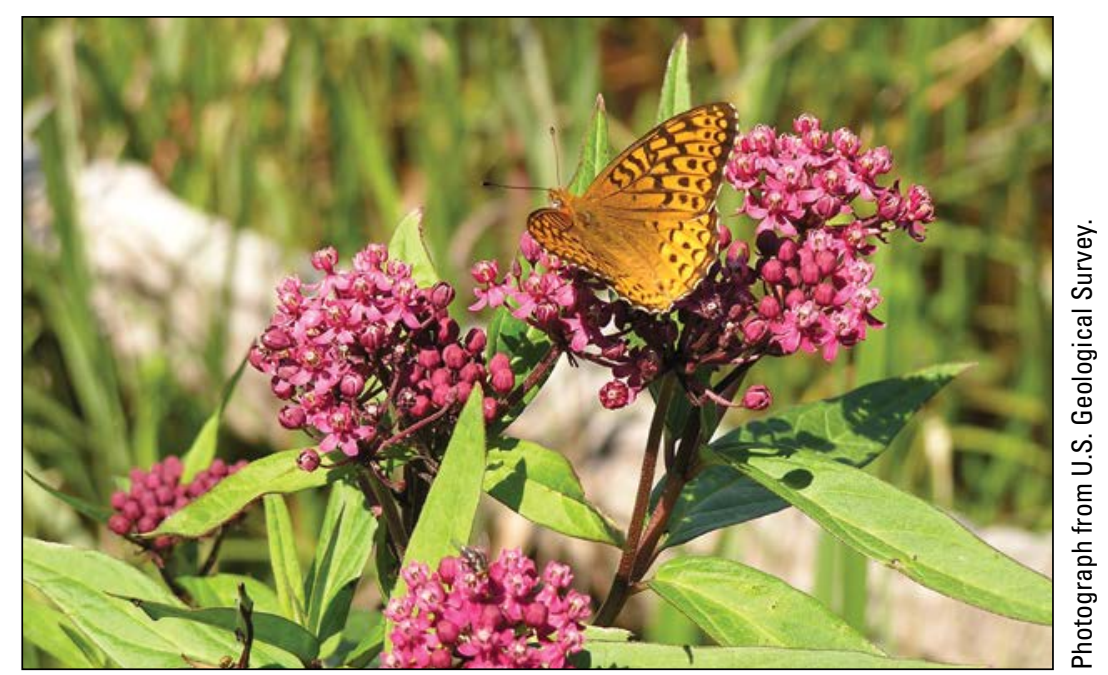

Meadow fritillary butterfly on swamp milkweed in the northern Great Plains.

\section{Using Drones and Citizen Science to Map the Distribution of Milkweed for Monarch Butterflies}

Agricultural intensification and the use of glyphosate-resistant crop varieties have contributed to the loss of milkweed in agricultural areas, including the bioenergy crop fields of the upper Midwest. The disappearance of milkweed, the essential host plant for monarch larva, has been implicated in the decline of the monarch butterfly, which was proposed for listing under the Endangered Species Act in 2014. In 2019, USGS scientists partnered with the Monarch Joint Venture to use unmanned aerial vehicles and machine learning software to census the distribution of milkweed on public and private lands in the upper Midwest. This work can inform the design of 21 st century monitoring programs for at-risk species and other natural resources.

\section{Contact}

Clint Otto, USGS Northern Prairie Wildlife Research Center, cotto@usgs.gov, (701) 253-5563

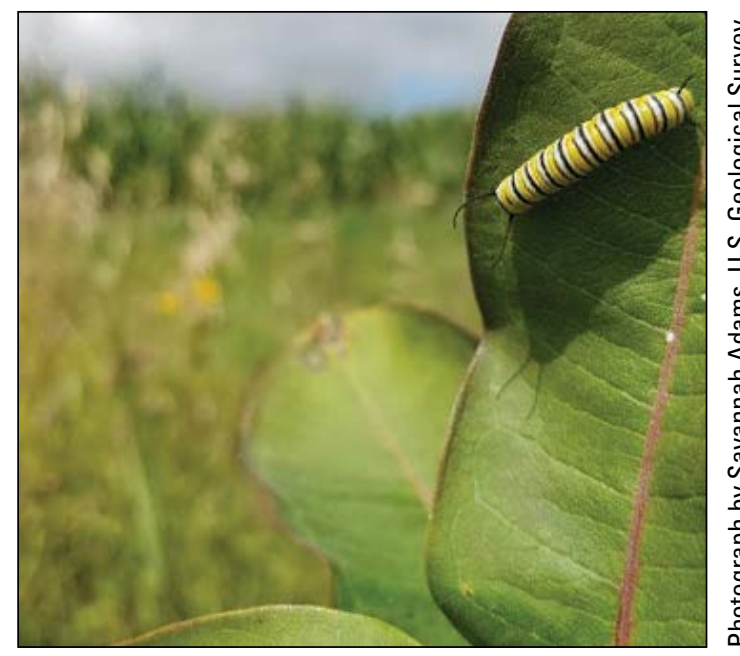

Left: Monarch caterpillar on milkweed in North Dakota. Right: Unmanned aerial systems (UAS) are being used by U.S. Geological Survey scientists to quantify the distribution of milkweed, a critical resource for monarch butterflies, in North Dakota and Minnesota.

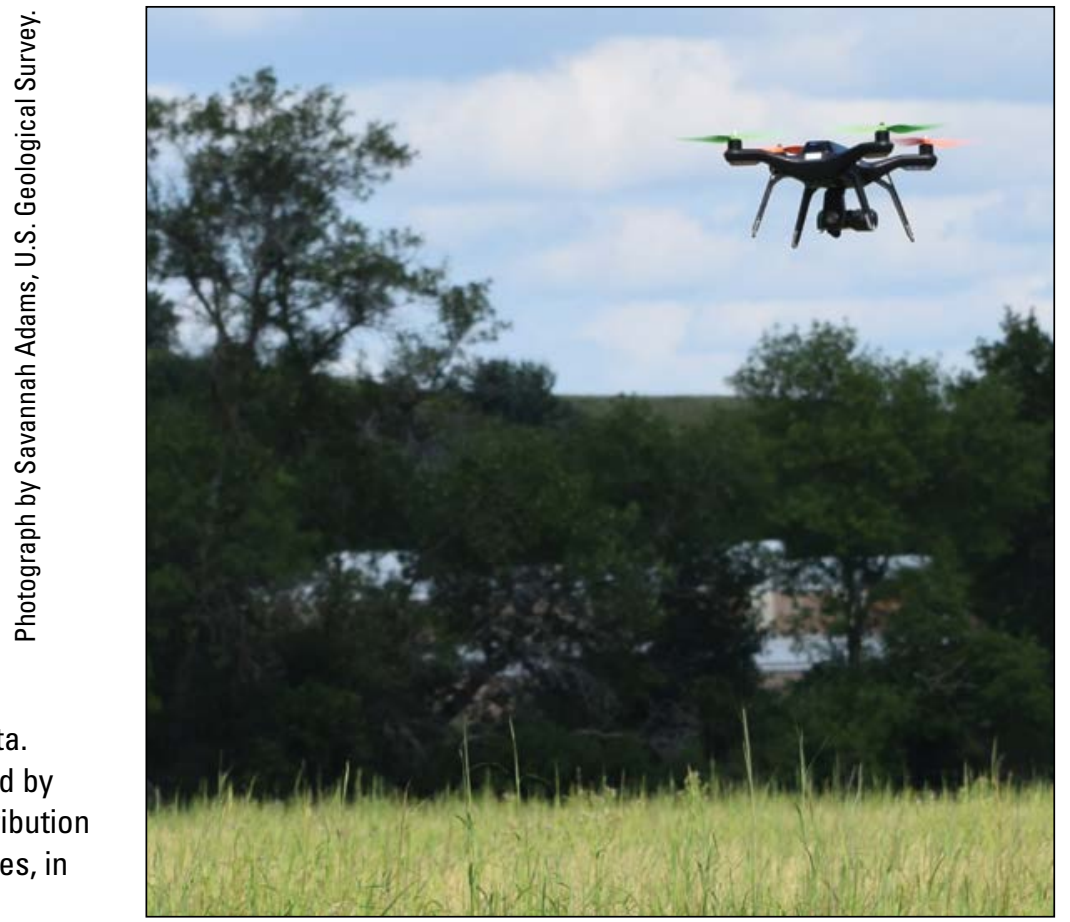




\section{Impact of Biofuel Crop Production on Pollinators in the Northern Great Plains}

The USGS, in cooperation with the U.S. Department of Agriculture (USDA), is quantifying how recent reductions in USDA conservation program enrollments affect pollinator habitat. Scientists are also developing a risk assessment model to identify what portions of the northern Great Plains have undergone the most substantial land-use changes due to biofuel crop development while also supporting the highest density of commercial beekeepers. This study addresses several of the key information needs to better understand, minimize, and recover from pollinator losses.

\section{Contact}

Clint Otto, USGS Northern Prairie Wildlife Research Center, cotto@usgs.gov, (701) 253-5563

\section{Publications}

Durant, J.L., and Otto, C.R.V., 2019, Feeling the sting? Addressing land-use changes can mitigate bee declines: Land Use Policy, v. 87 , article no. 104005,8 p., https://doi.org/10.1016/j.landusepol.2019.05.024.

Otto, C., 2019, Impacts of annual crops for biofuel production on wildlife, chap. 3 of Moorman, C.E., Grodsky, S.M., and Rupp, S.P., eds., Renewable energy and wildlife conservation: Balitmore, Md., Johns Hopkins University Press, p. 41-63.

Otto, C.R., Roth, C.L., Carlson, B.L., and Smart, M.D., 2016, Land-use change reduces habitat suitability for supporting managed honey bee colonies in the northern Great Plains: Proceedings of the National Academy of Sciences, v. 113, no. 37, p. 10430-10435, https://doi.org/10.1073/pnas.1603481113.

Otto, C.R.V., Zheng, H., Gallant, A.L., Iovanna, R., Carlson, B.L., Smart, M.D., and Hyberg, S., 2018, Past role and future outlook of the Conservation Reserve Program for supporting honey bees in the Great Plains: Proceedings of the National Academy of Sciences, v. 115, no. 29, p. 7629-7634, https://doi.org/10.1073/pnas.1800057115.

Smart, M., Otto, C., Cornman, R., and Iwanowicz, D., 2018, Using colony monitoring devices to evaluate the impacts of land use and nutritional value of forage on honey bee health: Agriculture, v. 8, no. 1, 14 p., https://doi.org/10.3390/ agriculture8010002.

Smart, M.D., Otto, C.R.V., Carlson, B.L., and Roth, C.L., 2018, The influence of spatiotemporally decoupled land use on honey bee colony health and pollination service delivery: Environmental Research Letters, v. 13, no. 8, 11 p., https://doi.org/10.1088/1748-9326/aad4eb.

Spivak, M., Browning, Z., Goblirsch, M., Lee, K., Otto, C., Smart, M., and Wu-Smart, J., 2017, Why does bee health matter? The science surrounding honey bee health concerns and what we can do about it: The Council of Agricultural Science and Technology [CAST], CAST Commentary, QTA2017, June, http://www.cast-science.org/publications/?why_does_bee_health_ matter_the_science_surrounding_honey_bee_health_concerns_and_what_we_can_do_about_it\&show=product\&produc $\mathrm{tID}=284638$.

U.S. Geological Survey, 2016, USGS pollinator research and monitoring [Kirk Mason, producer; Clint Otto, videographer]: U.S. Geological Survey video, 00:05:02, https://www.youtube.com/watch?v=3_O6RDdrfDc. 


\section{Taxonomic Characterization of Bee Pollen Foraging}

USGS scientists recently developed a genetic sequencing technique to identify pollen collected by foraging bees. The scientists are now using this technique to understand how land-use change and biofuel crop development affect honey bee forage in agroecosystems. They are also modeling historic forage patterns of the federally endangered rusty patched bumble bee on the basis of pollen collected from pinned museum specimens. In 2019, USGS scientists collected pollen from 95 rusty patched bumble bee museum specimens captured between 1923 and 2013 in States ranging from Minnesota to Massachusetts. The deoxyribonucleic acid (DNA) fragments from these pollen samples are currently being identified. Results generated from this project can be used to evaluate specific plants that can be included in conservation and restoration programs for pollinators. Partners in this research include the USDA, the USFWS, and the Keystone Institute.

\section{Contact}

Clint Otto, USGS Northern Prairie Wildlife Research Center, cotto@usgs.gov, (701) 253-5563

\section{Publications}

Cornman, R.S., Otto, C.R.V., Iwanowicz, D., and Pettis, J.S., 2015, Taxonomic characterization of honey bee (Apis mellifera) pollen foraging based on non-overlapping paired-end sequencing of nuclear ribosomal loci: PLOS ONE, v. 10, no. 12, e0145365, 26 p., https://doi.org/10.1371/journal.pone.0145365.

Smart, M.D., Cornman, R.S., Iwanowicz, D.D., McDermott-Kubeczko, M., Pettis, J.S., Spivak, M.S., and Otto, C.R.V., 2017, A comparison of honey bee-collected pollen from working agricultural lands using light microscopy and ITS metabarcoding: Environmental Entomology, v. 46, no. 1, p. 38-49, https://doi.org/10.1093/ee/nvw159.

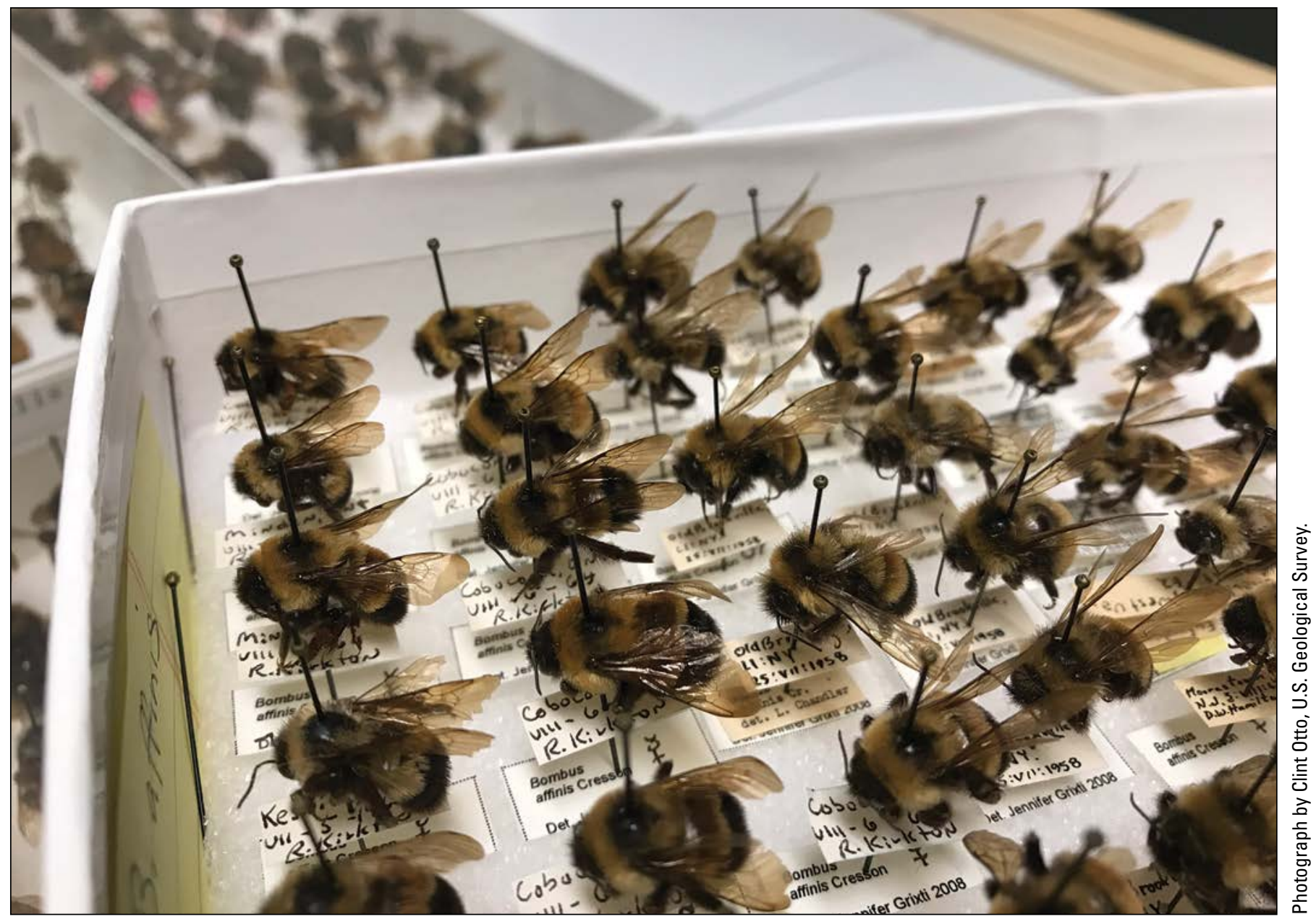

U.S. Geological Survey scientists are removing and identifying pollen from rusty patched bumble bee museum specimens to describe the historic floral diets of this endangered species. 


\section{Designing Conservation Seeding Mixes}

USGS scientists are working with the USDA to quantify the benefits of USDA conservation lands for supporting healthy pollinator populations in the northern Great Plains. One tool that can assist USDA managers is the USGS-developed Pollinator Library (https://www.npwrc.usgs.gov/pollinator/). This library is a repository of insect visitation and environmental and land-use information that can assist land managers with conservation seeding mix designs for land enhancement programs. This tool may be useful for restoring habitat for pollinators in areas where marginally productive lands are retired from biofuel crop production.

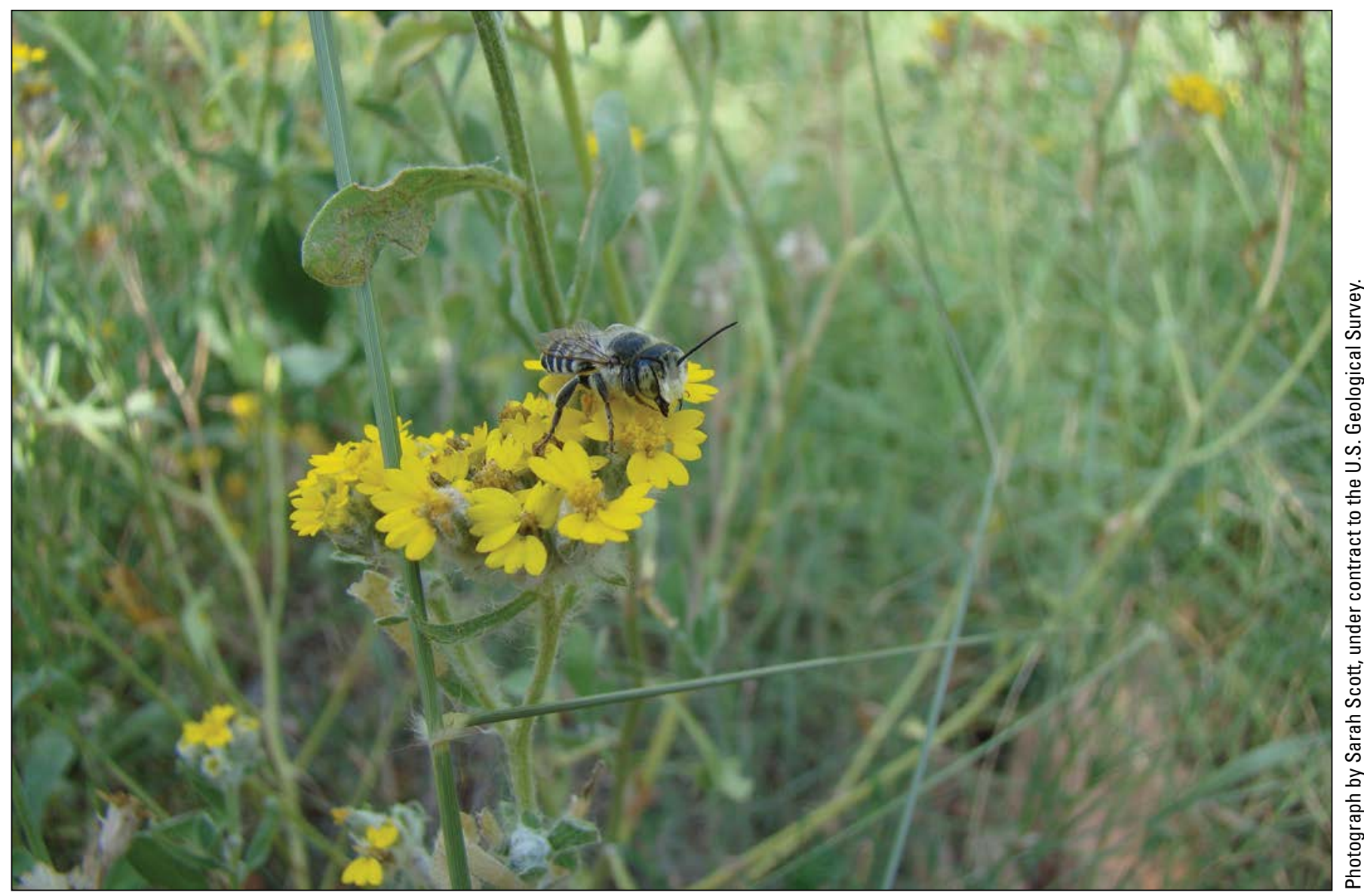

A native bee rests on woolly paperflower.

\section{Contact}

Clint Otto, USGS Northern Prairie Wildlife Research Center, cotto@usgs.gov, (701) 253-5563

\section{Publications}

Iovanna, R., Ando, A., Swinton, S., Kagan, J., Hellerstein, D., Mushet, D., and Otto, C., 2017, Assessing pollinator habitat services to optimize conservation programs, chap. 1 of The Council on Food, Agricultural and Resource Economics (C-FARE) Report: Washington, D.C., C-FARE, report no. 0114-301b, 28 p., http://www.cfare.org/youtube-videos/2017/8/30/ ysgngrouizyu4mie6647rcblm6jnj6.

Otto, C.R.V., 2019, Assessing the impact of the Conservation Reserve Program on honey bee health: U.S. Geological Survey Fact Sheet 2018-3082, 2 p., https://doi.org/10.3133/fs20183082.

Otto, C.R.V., O’Dell, S., Bryant, R.B., Euliss, N.H., Jr., Bush, R.M., and Smart, M.D., 2017, Using publicly available data to quantify plant-pollinator interactions and evaluate conservation seeding mixes in the northern Great Plains: Environmental Entomology, v. 46, no. 3, p. 565-578, https://doi.org/10.1093/ee/nvx070. 


\section{Reptiles and Amphibians and Land-Based Energy}

Conventional and renewable energy projects are adding stressors to reptile and amphibian populations experiencing population declines across the United States and worldwide (Adams and others, 2013; Lovich and others, 2018). The USFWS lists 30 species of amphibians and 32 species of reptiles as threatened or endangered in the United States. In addition, dozens of amphibian and reptile species are considered at risk. To address declines in amphibian populations, the USGS formed the Amphibian Research and Monitoring Initiative (ARMI) to study the life history traits of amphibians, measure and monitor environmental characteristics, and research potential causes of decline. Scientists are assessing the effects of land-use change from oil and gas development, wind and solar energy development, and power lines and geothermal power plants, in addition to other stressors, to better understand impacts of energy infrastructure on these sensitive species.

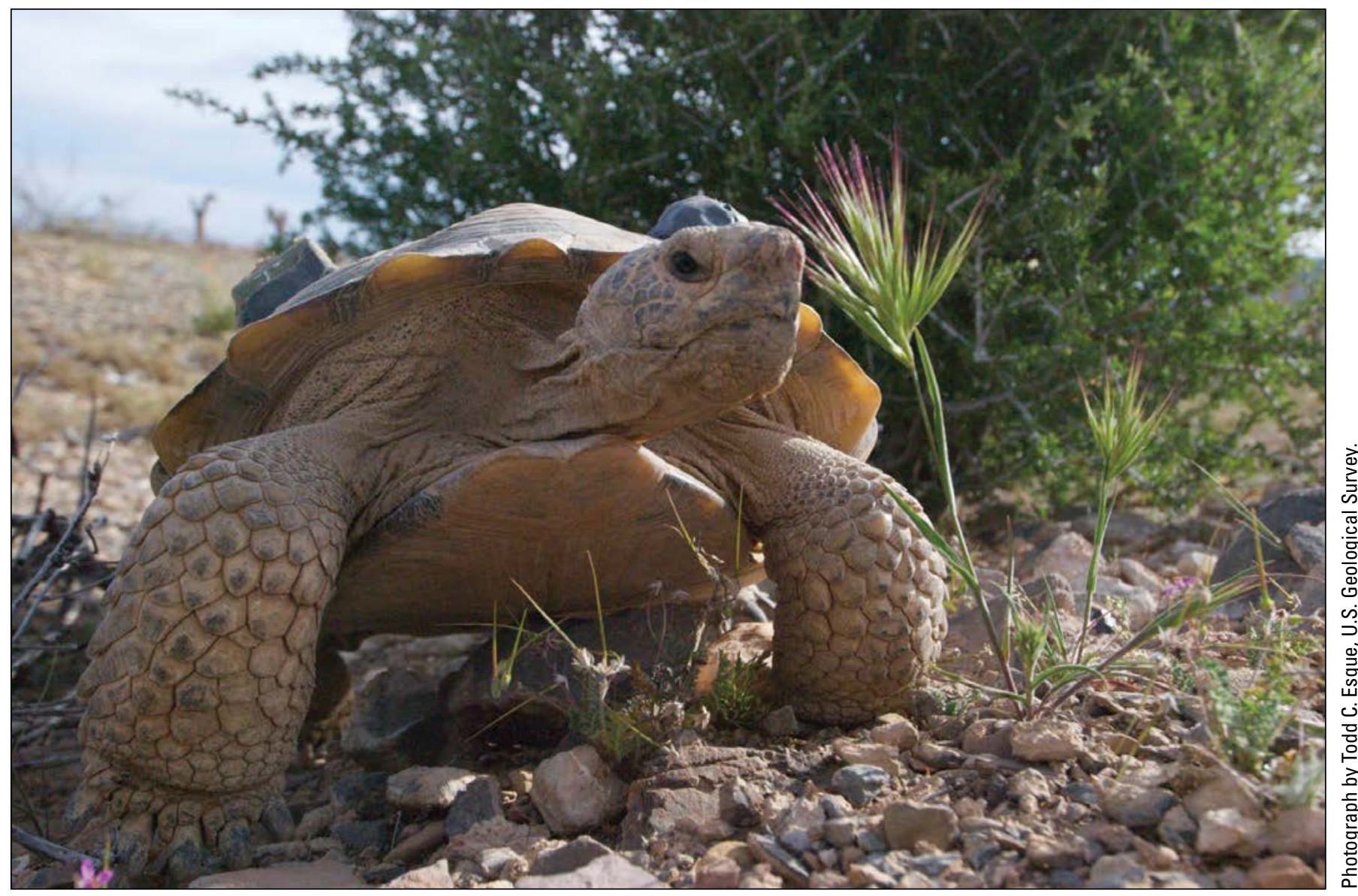

Male desert tortoise.

\section{Desert Tortoise Recovery and Habitat Restoration}

Renewable energy projects in southern California are frequently sited in desert tortoise habitat, creating the need to translocate tortoises to new areas. USGS scientists are studying wind and solar energy facility impacts to desert tortoise to better understand the behavior responses of this endangered species. Researchers are also studying desert tortoise habitat, including vegetation of the Mojave and Sonoran Deserts, disease prevalence, and tortoise shelter choices in support of wildlife and land management decisions regarding site selection for tortoise translocations.

\section{Contacts}

Kristin Berry, USGS Western Ecological Research Center, kristin_berry@usgs.gov, (951) 697-5361

Todd Esque, USGS Western Ecological Research Center, tesque@usgs.gov, (702) 564-4506

Jeffrey Lovich, USGS Southwest Biological Science Center, jeffrey_lovich@usgs.gov, (928) 556-7358 


\section{Publications}

Abella, S.R., and Berry, K.H., 2016, Enhancing and restoring habitat for the desert tortoise: Journal of Fish and Wildlife Management, v. 7, no. 1, p. 255-279, https://doi.org/10.3996/052015-JFWM-046.

Gray, M.E., Dickson, B.G., Nussear, K.E., Esque, T.C., and Chang, T., 2019, A range-wide model of contemporary, omnidirectional connectivity for the threatened Mojave desert tortoise: Ecosphere, v. 10, no. 9, e02847, 16 p., https://doi.org/10.1002/ecs2.2847.

Lovich, J.E., Agha, M., Ennen, J.R., Arundel, T.R., and Austin, M., 2018, Agassiz's desert tortoise (G opherus agassizii) activity areas are little changed after wind turbine-induced fires in California: International Journal of Wildland Fire, v. 27, no. 12, p. 851-856, https://doi.org/10.1071/WF18147.

Mack, J.S., Schneider, H.E., and Berry, K.H., 2018, Crowding affects health, growth, and behavior in headstart pens for Agassiz's desert tortoise: Chelonian Conservation and Biology, v. 17, no. 1, p. 14-26, https://doi.org/10.2744/CCB-1248.1.

Sánchez-Ramírez, S., Rico, Y., Berry, K.H., Edwards, T., Karl, A.E., Henen, B.T., and Murphy, R.W., 2018, Landscape limits gene flow and drives population structure in Agassiz's desert tortoise (Gopherus agassizii): Scientific Reports, v. 8, article no. 11231, 17 p., https://doi.org/10.1038/s41598-018-29395-6.

\section{int}

Several species and subspecies of toads (Anaxyrus spp.) in the Great Basin are endemic to small spring systems, some of which are in areas that may be suitable for geothermal and other energy development. In 2018, the USGS, in collaboration with the BLM, USFWS, Department of Defense, and Nevada Department of Wildlife, developed a research and monitoring program designed to better understand the ecology of narrowly endemic toads in the Great Basin. Initial results suggest that Dixie Valley toads are selective with regard to water temperature, with adults selecting cooler temperatures than tadpoles. This ecological trait could indicate sensitivity to changes in the hydrothermal system supporting the toad's habitat. Ongoing research on the distribution of the toads, the spatiotemporal availability of preferred water temperatures, and toad habitat selection can further inform management of Dixie Valley toads.

\section{Contact}

Brian Halstead, USGS Western Ecological

Research Center, bhalstead@usgs.gov, (530) 669-5076

\section{Publication}

Halstead, B.J., Kleeman, P.M., Duarte, A., Rose, J.P., Urquhart, K., Mellison, C., Guadalupe, K., Cota, M., Van Horne, R., Killion, A., and Ruehling, K., 2019, Monitoring protocol development and assessment for narrowly endemic toads in Nevada, 2018: U.S. Geological Survey Open-File Report 2019-1067, 28 p., https://doi.org/10.3133/ofr20191067.

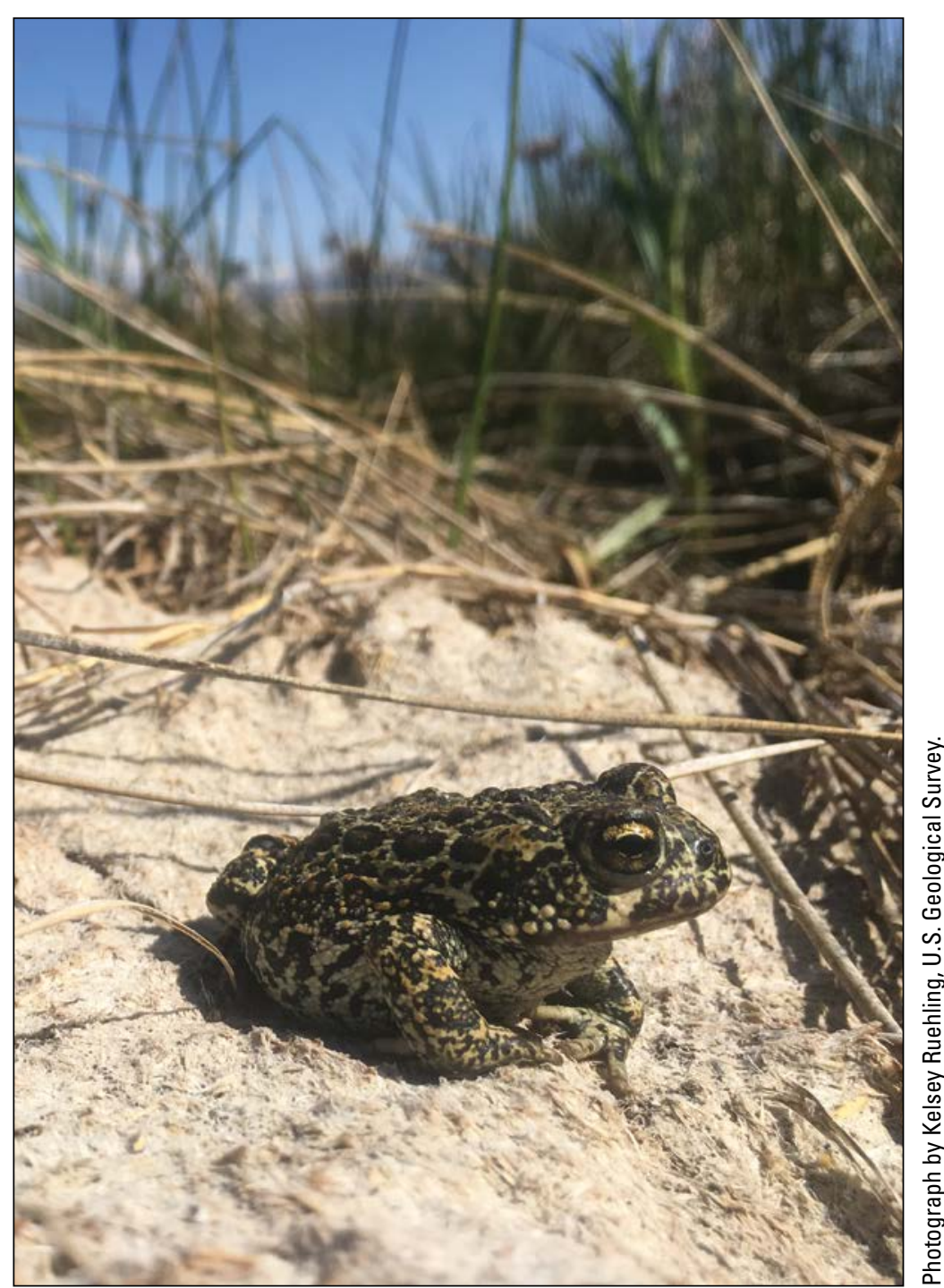

Dixie Valley toad. 


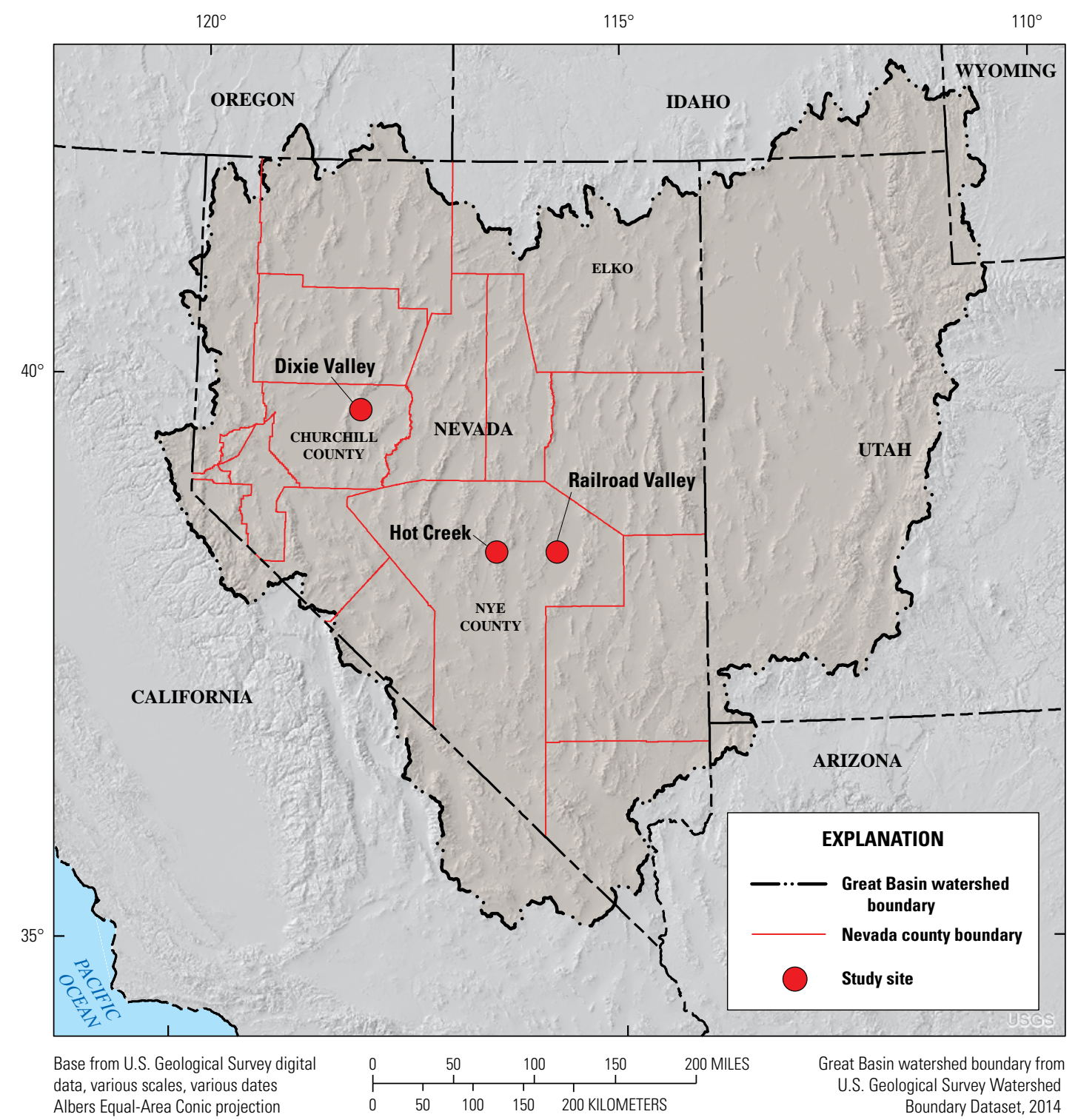

Location of the Great Basin watershed in the Western United States. Study sites are indicated with circles; counties in which research was conducted are labeled (modified from Halstead and others, 2019).

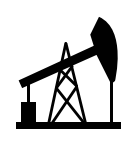

\section{Effects of Brine Contamination on Amphibians}

USGS scientists are examining how saline wastewaters (brines) co-produced during legacy oil extraction in the Williston Basin in the northern Great Plains affect wetlands and amphibians. Field studies found that the abundance of frog larvae in wetlands was sensitive to levels of brine contamination. Notably, water quality and amphibian abundance were more strongly related to presence of nearby oil wells installed before 1982 than to wells installed since 1982, when changes to brine disposal practices reduced the incidence and extent of environmental contamination. Scientists also examined concentrations of 15 metals in sediments and amphibian tissues and found that metal concentrations were less strongly associated with brine contamination of wetlands than expected. Elevated levels of only sodium and strontium were found in sediments, and elevated levels of only selenium and vanadium were found in amphibian tissues. Counter to expectations, grazing benthic tadpoles had higher metal concentrations than predatory salamanders that spend less time in contact with sediment. Improved brine disposal practices are reducing exposure of amphibians to metals in wetland sediments.

\section{Contact}

Blake Hossack, USGS Northern Rocky Mountain Science Center, blake_hossack@usgs.gov, (406) 542-3245 


\section{Publications}

Hossack, B.R., Puglis, H.J., Battaglin, W.A., Anderson, C.W., Honeycutt, R.K., and Smalling, K.L., 2017, Widespread legacy brine contamination from oil production reduces survival of chorus frog larvae: Environmental Pollution, v. 231, pt. 1, p. 742-751, https://doi.org/10.1016/j.envpol.2017.08.070.

Hossack, B.R., Smalling, K.L., Anderson, C.W., Preston, T.M., Cozzarelli, I.M., and Honeycutt, R.K., 2018, Effects of persistent energy-related brine contamination on amphibian abundance in national wildlife refuge wetlands: Biological Conservation, v. 228, p. 36-43, https://doi.org/10.1016/j.biocon.2018.10.007.

Smalling, K.L., Anderson, C.W., Honeycutt, R.K., Cozzarelli, I.M., Preston, T., and Hossack, B., 2019, Associations between environmental pollutants and larval amphibians in wetlands contaminated by energy-related brines are potentially mediated by feeding traits: Environmental Pollution, v. 248, p. 260-268, https://doi.org/10.1016/j.envpol.2019.02.033.

\section{Additional Publications}

\section{Desert Tortoise}

Agha, M., Lovich, J.E., Ennen, J.R., Augustine, B., Arundel, T.R., Murphy, M.O., Meyer-Wilkins, K., Bjurlin, C., Delaney, D., Briggs, J., Austin, M., Madrak, S.V., and Price, S.J., 2015, Turbines and terrestrial vertebrates - Variation in tortoise survivorship between a wind energy facility and an adjacent undisturbed wildland area in the desert Southwest (U.S.A.): Environmental Management, v. 56, no. 2, p. 332-341, https://doi.org/10.1007/s00267-015-0498-9.

Agha, M., Smith, A.L., Lovich, J.E., Delaney, D., Ennen, J.R., Briggs, J., Fleckenstein, L.J., Tennant, L.A., Puffer, S.R., Walde, A., Arundel, T.R., Price, S.J., and Todd, B.D., 2017, Mammalian mesocarnivore visitation at tortoise burrows in a wind farm: Journal of Wildlife Management, v. 81, no. 6, p. 1117-1124, https://doi.org/10.1002/jwmg.21262.

Berry, K.H., Lyren, L.M., Mack, J.S., Brand, L.A., and Wood, D.A., 2016, Desert tortoise annotated bibliography, 1991-2015: U.S. Geological Survey Open-File Report 2016-1023, 312 p., https://doi.org/10.3133/ofr20161023.

Bowen, L., Miles, A.K., Drake, K.K., Waters, S.C., Esque, T.C., and Nussear, K.E., 2015, Integrating gene transcription-based biomarkers to understand desert tortoise and ecosystem health: EcoHealth, v. 12, no. 3, p. 501-512, https://doi.org/10.1007/ s10393-014-0998-8.

Drake, K.K., Bowen, L., Nussear, K.E., Esque, T.C., Berger, A.J., Custer, N.A., Waters, S.C., Johnson, J.D., Miles, A.K., and Lewison, R.L., 2016, Negative effects of invasive plants on conservation of sensitive desert wildlife: Ecosphere, v. 7, no. 10, e01531, 20 p., https://doi.org/10.1002/ecs2.1531.

Ennen, J.R., Lovich, J.E., Averill-Murray, R.C., Yackulic, C.B., Agha, M., Loughran, C., Tennant, L., and Sinervo, B., 2017, The evolution of different maternal investment strategies in two closely related desert vertebrates: Ecology and Evolution, v. 7, no. 9, p. 3177-3189, https://doi.org/10.1002/ece3.2838.

Lovich, J.E., 2015, Case study—Road proliferation due to rapid renewable energy development, a section of chap. 4 in Andrews, K.A., Nanjappa, P., and Riley, S.P.D., eds., Roads and ecological infrastructure-Concepts and applications for small animals: Baltimore, Md., Johns Hopkins University Press and The Wildlife Society, p. 79-84.

Lovich, J.E., and Ennen, J.R., 2016, Energy development, in Jones, L.L.C., Halama, K.J., and Lovich, R.E., eds., Habitat management guidelines for amphibians and reptiles of the Southwestern United States: Birmingham, Ala., Partners in Amphibian and Reptile Conservation, Technical Publication HMG-5, 193 p.

Lovich, J.E., and Ennen., J.R., 2017, Reptiles and amphibians, chap. 6 of Perrow, M.R., ed., Wildlife and windfarms, conflicts and solutions, v. 1, Onshore-Potential effects: Exeter, England, Pelagic, p. 97-118.

\section{Amphibians}

Sweeten, S.E., and Ford, W.M., 2016, Effects of microhabitat and large-scale land use on stream salamander occupancy in the coalfields of central Appalachia: Journal of Ecology and the Natural Environment, v. 8, no. 9, p. 129-141, https://doi.org/10.5897/JENE2016.0564.

Sweeten, S.E., and Ford, W.M., 2016, Validation of a stream and riparian habitat assessment protocol using stream salamanders in the southwest Virginia coalfields: Journal of American Society of Mining and Reclamation, v. 5, no. 1, p. 45-66, https://doi.org/10.21000/jasmr16010045. 


\section{Big Game and Other Terrestrial Mammals and Land-Based Energy}

Landscape fragmentation due to oil and gas energy development, wind facilities, and associated service roads can affect seasonal migration, reproduction, and survival of big game species such as mule deer, pronghorn antelope, elk, and other terrestrial mammals (Wyckoff and others, 2018). Creation of barriers along migration routes and altered predator communities may also present new stressors. USGS scientists assist State and Federal resource and land management agencies such as the BLM and USFWS in evaluating the potential effects of energy facility expansion and energy production activities by studying big game migration corridors and behavior relative to anthropogenic disturbance. Research efforts are also focused on identifying strategies that can minimize adverse impacts to these species.

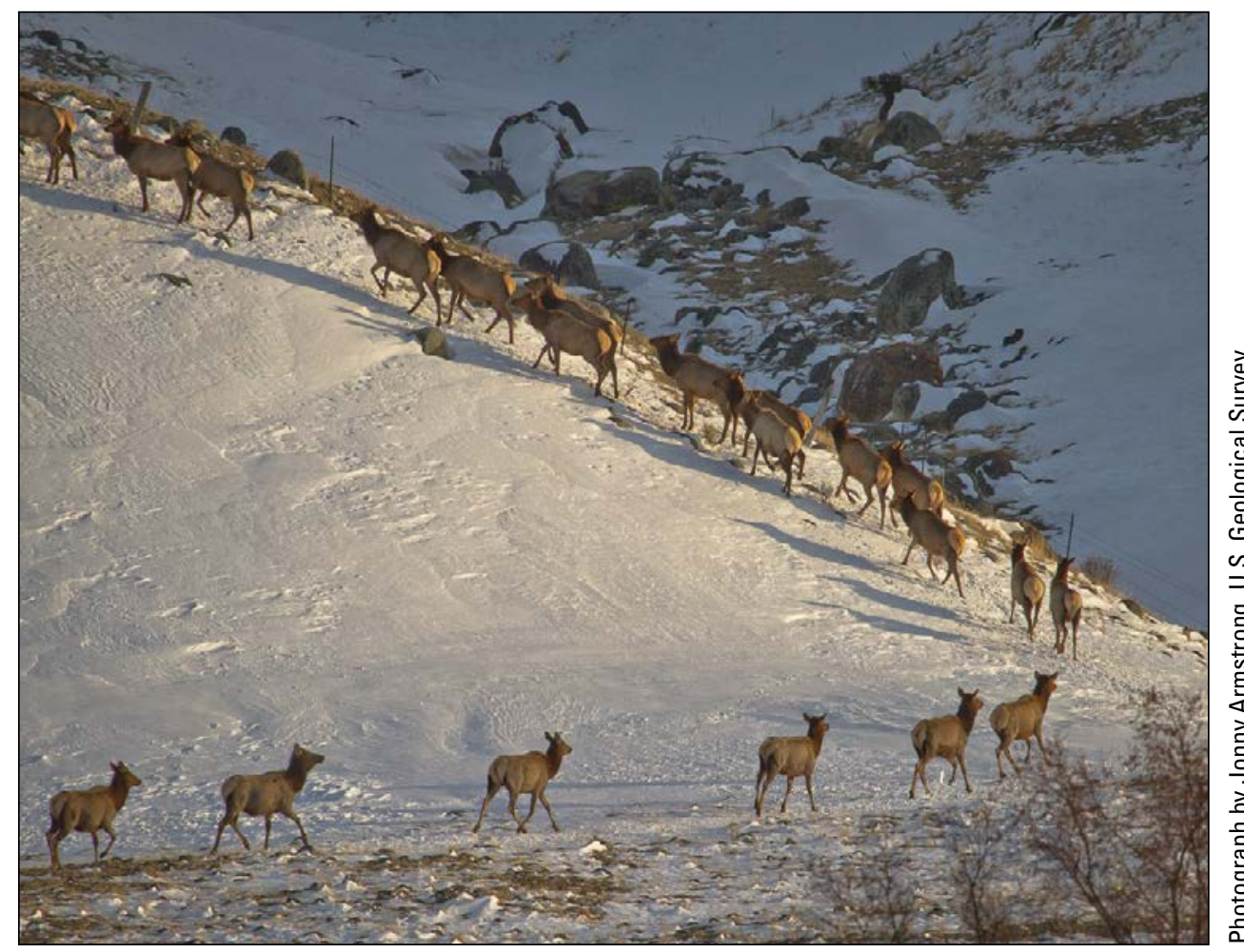

Elk traveling on winter range in the northwestern Greater Yellowstone Ecosystem after crossing the Madison River near Ennis, Montana.

边

\section{Migration Corridors for Big Game}

As habitat loss and fragmentation increase across ungulate ranges, identifying and prioritizing migration routes for land-use planning and conservation has taken on a new urgency. Research attention is currently focused on determining whether continued energy development will lead to the loss of the foraging benefit of migration. USGS research in Wyoming has advanced our understanding of the importance of migration for large ungulates in the West, specifically quantifying how migrating animals track spring green-up during migration, a behavior termed "surfing the green wave." Research on corridors in which migrating animals interact with housing and energy development suggests that the resulting behavioral modifications can alter optimal foraging. In collaboration with Federal, State, and university partners, the USGS has developed the Migration Mapper (https://migrationinitiative.org/content/migration-mapper) software that provides a step-by-step analysis to map

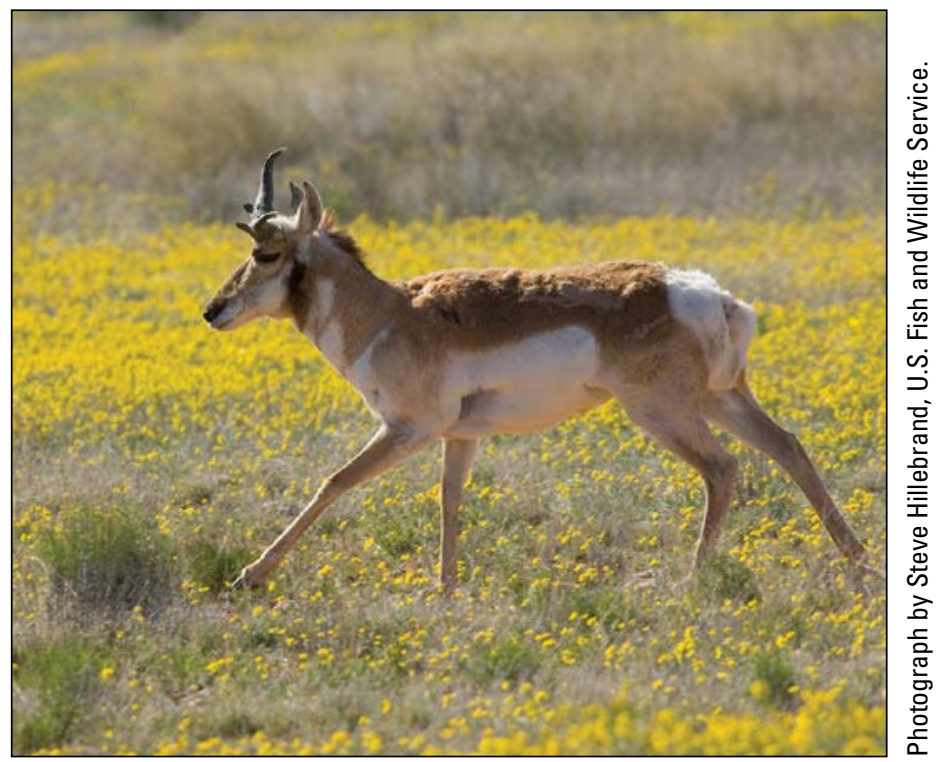

Adult pronghorn. 
migration corridors from the underlying GPS locations. Resulting corridor maps can easily be made available for managers, policymakers, land trusts, sportsmen's groups, and other NGOs to use in conservation planning. A current effort is underway, through USGS-led regional workshops, to train wildlife managers from Western States to analyze migration data, and the USGS continues to develop tools and methods necessary to identify opportunities to enhance conservation and management of ungulate migration corridors.

\section{Contact}

Matthew Kauffman, USGS Wyoming Cooperative Fish and Wildlife Research Unit, mkauffm1@uwyo.edu, mkauffman@usgs.gov, (307) 766-5415

\section{Publications}

Aikens, E.O., Kauffman, M.J., Merkle, J.A., Dwinnell, S.P.H., Fralick, G.L., and Monteith, K.L., 2017, The greenscape shapes surfing of resource waves in a large migratory herbivore: Ecology Letters, v. 20, no. 6, p. 741-750, https://doi.org/10.1111/ ele. 12772 .

Courtemanch, A.B., Kauffman, M.J., Kilpatrick, S., and Dewey, S.R., 2017, Alternative foraging strategies enable a mountain ungulate to persist after migration loss: Ecosphere, v. 8, no. 6, e01855, 16 p., https://doi.org/10.1002/ecs2.1855.

Merkle, J.A., Monteith, K.L., Aikens, E.O., Hayes, M.M., Hersey, K.R., Middleton, A.D., Oates, B.A., Sawyer, H., Scurlock, B.M., and Kauffman, M.J., 2016, Large herbivores surf waves of green-up during spring: Proceedings of the Royal Society B-Biological Sciences, v. 283, no. 1833, 8 p., https://doi.org/10.1098/rspb.2016.0456.

Middleton, A.D., Merkle, J.A., McWhirter, D.E., Cook, J.G., Cook, R.C., White, P.J., and Kauffman, M.J., 2018, Green-wave surfing increases fat gain in a migratory ungulate: Oikos, v. 127, no. 7, p. 1060-1068, https://doi.org/10.1111/oik.05227.

Sawyer, H., Middleton, A.D., Hayes, M.M., Kauffman, M.J., and Monteith, K.L., 2016, The extra mile—Ungulate migration distance alters the use of seasonal range and exposure to anthropogenic risk: Ecosphere, v. 7, no. 10, e01534, 11 p., https://doi.org/10.1002/ecs2.1534.

Wyckoff, T.B., Sawyer, H., Albeke, S.E., Garman, S.L., and Kauffman, M.J., 2018, Evaluating the influence of energy and residential development on the migratory behavior of mule deer: Ecosphere, v. 9, no. 2, e02113, 13 p., https://doi.org/10.1002/ecs2.2113.

\section{Pronghorn Responses to Wind Farms}

In Wyoming, new wind farms are planned for construction within critical winter range for pronghorn, but little is known about pronghorn responses to wind energy infrastructure and operations. In collaboration with the WLCI, USGS scientists are evaluating changes in movement and habitat use of pronghorn tracked with GPS collars from before construction of two wind farms (construction began in spring 2019) to several years after construction. This analysis includes an assessment of the long-term effects of wind farms on pronghorn through comparisons of recent habitat use within an existing wind farm to movement data collected during and after construction of the wind farm from 2010 to 2012. Results can inform land and wildlife managers of risks for pronghorn associated with further development of wind energy that is expected in this region.

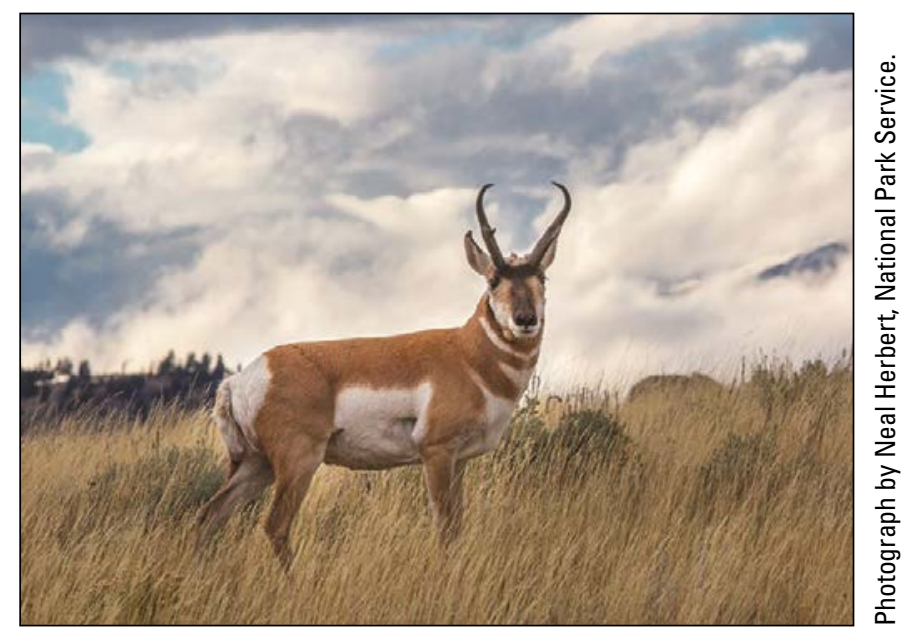

North American pronghorn.

\section{Contacts}

Matthew Kauffman, USGS Wyoming Cooperative Fish and Wildlife Research Unit, mkauffm1@uwyo.edu, mkauffman@usgs.gov, (307) 766-6404

Aaron Johnston, USGS Northern Rocky Mountain Science Center, ajohnston@usgs.gov, (406) 994-7158 


\section{Influence of Oil Development on the Behavior of Barren-Ground Caribou}

Interest in oil and gas production on the North Slope of Alaska is raising questions about the resilience of barren-ground caribou populations to new development. Although the amount of habitat lost directly to energy development in the Arctic will likely be small in relation to the total area, there are significant concerns about indirect effects such as avoidance behaviors by caribou. To understand the long-term effects of energy development on barren-ground caribou, USGS scientists are investigating the behavior of the Central Arctic Herd, which has been exposed to oil development on its summer range for approximately 40 years. Using recent (2015-2017) location data from GPS-collared females, scientists are conducting a zone of influence analysis to assess whether caribou reduce their use of habitat near energy development, and if so, the distance at which the effects attenuate. Analyses include periods of calving and post-calving and mosquito periods when caribou exhibit distinct resource selection patterns. New findings will be compared to past research on the herd that was conducted immediately after the development of the oil fields. Results from this work can be used by Federal land management agencies to better understand the long-term impacts of energy development on caribou behavior.

\section{Contact}

Heather Johnson, USGS Alaska Science Center, heatherjohnson@usgs.gov, (907) 786-7155

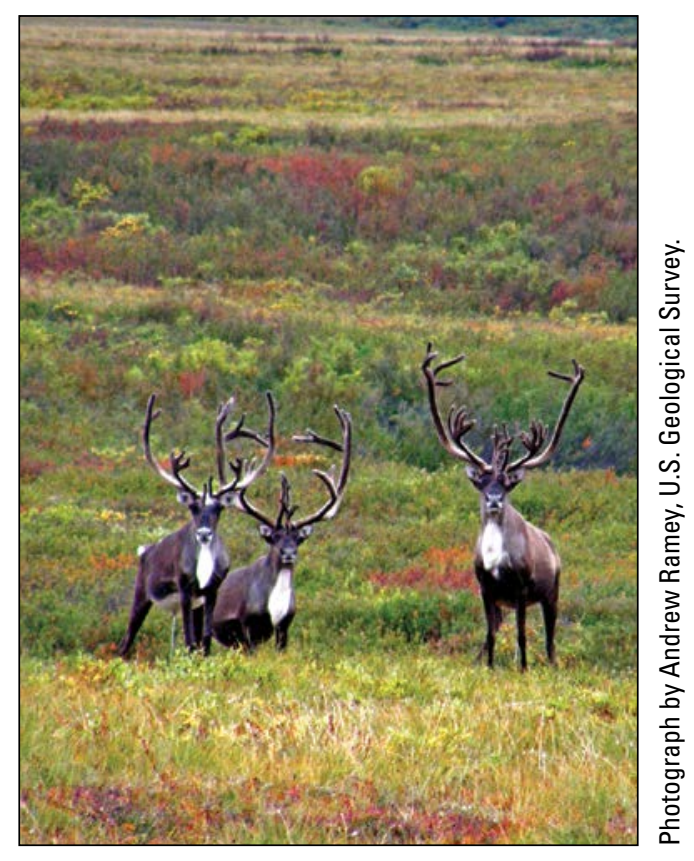

Three caribou standing in the tundra in Alaska.

\section{Measuring the Impacts of Industrial Activities on Polar Bears}

USGS scientists are characterizing changes in the abundance, distribution, and health of polar bears relative to human activities in the Arctic. These studies emphasize the identification of critical habitats potentially at risk of disturbance from industrial activities along Alaska's Arctic coast. This work has informed efforts of DOI agencies and industry when considering the consequences of oil spills and exposures to pollutants and actions to mitigate such occurrences. The USGS continues to work closely with DOI and industry partners to identify circumstances in which industrial activities likely adversely affect polar bears. Future work is expected to focus on the potential for resource development activities on land and offshore to directly and indirectly benefit polar bear behavior and health.

\section{Contact}

Grant V. Hilderbrand, USGS Alaska Science Center, ghilderbrand@usgs.gov, (907) 786-7076

\section{Publications}

Atwood, T.C., Marcot, B.G., Douglas, D.C., Amstrup, S.C., Rode, K.D., Durner, G.M., and Bromaghin, J.F., 2016, Forecasting the relative influence of environmental and anthropogenic stressors on polar bears: Ecosphere, v. 11, no. 6, e01370, 22 p., https://doi.org/10.1002/ecs2.1370.

Atwood, T.C., Peacock, E., McKinney, M.A., Lillie, K., Wilson, R., Douglas, D.C., Miller, S., and Terletzky, P., 2016, Rapid environmental change drives increased land use by an Arctic marine predator: PLOS ONE, v. 11, no. 6, e0155932, 18 p., https://doi.org/10.1371/journal.pone.0155932.

Durner, G.M., and Atwood, T.C., 2018, A comparison of photograph-interpreted and IfSAR-derived maps of polar bear denning habitat for the 1002 area of the Arctic National Wildlife Refuge, Alaska: U.S. Geological Survey Open-File Report 20181083, 12 p., https://doi.org/10.3133/ofr20181083.

McKinney, M.A., Atwood, T.C., Iverson, S.J., and Peacock, E., 2017, Temporal complexity of southern Beaufort Sea polar bear diets during a period of increasing land use: Ecosphere, v. 8, no. 1, e01633, 14 p., https://doi.org/10.1002/ecs2.1633.

McKinney, M.A., Atwood, T.C., Pedro, S., and Peacock, E., 2017, Ecological change drives a decline in mercury concentrations in southern Beaufort Sea polar bears: Environmental Science and Technology, v. 51, no. 14, p. 7814-7822, https://doi.org/10.1021/acs.est.7b00812. 


\section{Mitigating the Impacts of Energy Development on Polar Bears}

The USGS works closely with other DOI agencies to identify science needed to inform actions that mitigate the impacts of energy development on polar bears. Information generated by USGS scientists is used by the USFWS to guide regulations regarding the incidental take of polar bears by industry, BOEM to guide decisions regarding permitting of offshore oil and gas exploration and extraction, and the BLM to mitigate the effects of energy development on polar bears that den within the NPR-A. USGS work is focusing on improving decisionmaking tools for these agencies to assess the relative importance of environmental and anthropogenic stressors to polar bears.

\section{Contact}

Grant V. Hilderbrand, USGS Alaska Science Center, ghilderbrand@usgs.gov, (907) 786-7076

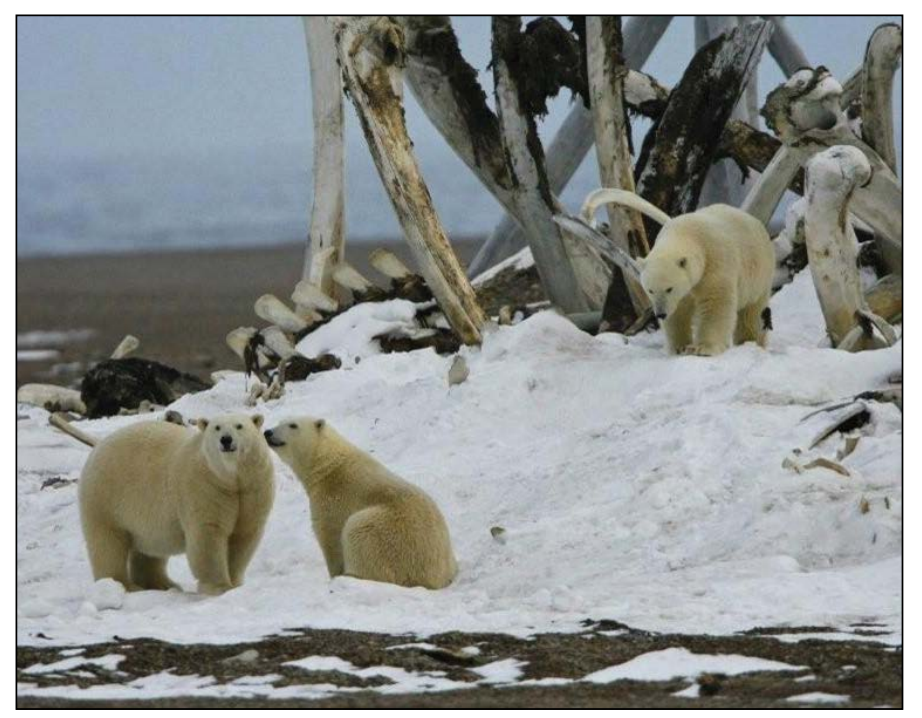

\section{Publications}

Atwood, T.C., Marcot, B.G., Douglas, D.C., Amstrup, S.C., Rode, K.D., Durner, G.M., and Bromaghin, J.F., 2016, Forecasting the relative influence of environmental and anthropogenic stressors on polar bears: Ecosphere, v. 7, no. 6, e01370, 22 p., https://doi.org/10.1002/ecs2.1370.

Durner, G.M., and Atwood, T.C., 2018, A comparison of photograph-interpreted and IfSAR-derived maps of polar bear denning habitat for the 1002 area of the Arctic National Wildlife Refuge, Alaska: U.S. Geological Survey Open-File Report 20181083, 12 p., https://doi.org/10.3133/ofr20181083.

Olson, J.W., Rode, K.D., Eggett, D., Smith, T.S., Wilson, R.R., Durner, G.M., Fischbach, A., Atwood, T.C., and Douglas, D.C., 2017, Collar temperature sensor data reveal long-term patterns in southern Beaufort Sea polar bear den distribution on pack ice and land: Marine Ecology Progress Series, v. 564, p. 211-224, https://doi.org/10.3354/meps12000.

Runge, M.C., Debold Kohout, J., Atwood, T., Colligan, M., Douglas, D., Oakley, K., Regehr, E., Rode, K., Servheen, C., Sparks, R., Titus, K., Wilder, J., and Wilson, R., 2017, Polar bear (U rsus maritimus) conservation management plan, final: Anchorage, Alaska, U.S. Fish and Wildlife Service, Region 7, 104 p., https://www.fws.gov/alaska/fisheries/mmm/polarbear/pdf/PBRT_ Recovery_\%20Plan_Book_FINAL_signed.pdf.

\section{Additional Publications}

Dorning, M.A., Garman, S.L., Diffendorfer, J.E., Semmens, D.J., Hawbaker, T.J., and Bagstad, K.J., 2017, Oil and gas development influences big-game hunting in Wyoming: Journal of Wildlife Management, v. 81, no. 3, p. 379-392, https://doi.org/10.1002/jwmg.21205.

Sirén, A.P.K., Pekins, P.J., Kilborn, J.R., Kanter, J.J., and Sutherland, C.S., 2017, Potential influence of high-elevation wind farms on carnivore mobility: Journal of Wildlife Management, v. 81, no. 8, p. 1505-1512, https://doi.org/10.1002/ jwmg.21317. 


\section{Coastal and Marine Birds and Offshore Energy}

Oil and gas extraction and related activities in the ocean may impact coastal and marine birds through collisions with infrastructure or exposure to at-sea oil pollution. Offshore wind-generated electricity promises to be an important source of renewable energy but may pose additional risk to coastal and marine birds that share airspace with future offshore wind facilities. USGS scientists assist regulatory agencies such as BOEM and the USFWS in evaluating the potential effects of offshore energy facilities and related activities by studying seabird movement, distribution, and flight and foraging behavior in the coastal and marine environment and by identifying areas of relative high and low overlap between seabird species of conservation concern and proposed offshore facilities.

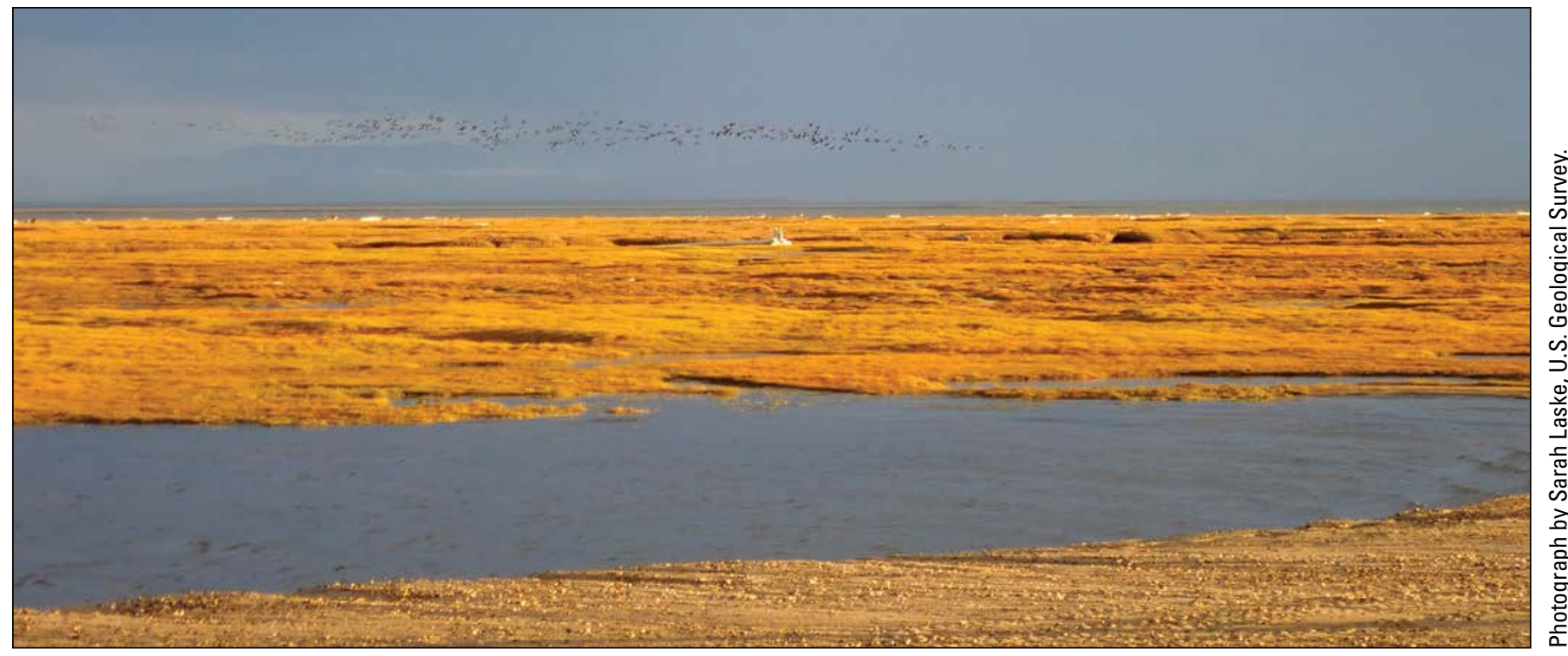

Flock of birds over Arey Island on the coastline of the Beaufort Sea near Kaktovik, Alaska.

\section{Alaska}

\section{North Pacific Pelagic Seabird Survey}

The USGS produced the North Pacific Pelagic Seabird Database (https://alaska.usgs.gov/science/biology/nppsd/index. php), an online resource compiling the results of 40 years of bird surveys from the United States, Canada, Japan, and Russia. The database documents the abundance and distribution of 160 seabird and 41 marine mammal species over a 26-millionsquare-kilometer, or 10-million-square-mile, region of the North Pacific. This database is a powerful tool for analysis and mitigation of anthropogenic effects on marine ecosystems of the Arctic and North Pacific, including the impacts of oil development and production, fisheries, and vessel traffic. Use of this tool also provides an opportunity to study the biogeography and marine ecology of dozens of species of seabirds and marine mammals throughout their range in continental shelf waters of the United States.

\section{Contacts}

Gary S. Drew, USGS Alaska Science Center, gdrew@usgs.gov, (907) 786-7168

John Piatt, USGS Alaska Science Center, jpiatt@usgs.gov, (360) 774-0516

\section{Publications}

Drew, G.S., Piatt, J.F., and Renner, M., 2015, User's guide to the North Pacific Pelagic Seabird Database 2.0: U.S. Geological Survey Open-File Report 2015-1123, 52 p., https://doi.org/10.3133/ofr20151123.

Renner, M., Salo, S., Eisner, L.B., Ressler, P.H., Ladd, C., Kuletz, K.J., Santora, J.A., Piatt, J.F., Drew, G.S., and Hunt, G.L., 2016, Timing of ice retreat alters seabird abundances and distributions in the southeast Bering Sea: Biological Letters, v. 12, no. 9, e20160276, 7 p., https://doi.org/10.1098/rsbl.2016.0276. 


\section{Status of Seabirds and Forage Fish in Cook Inlet, Alaska}

Seabird densities in lower Cook Inlet are among the highest in Alaska, and populations were decimated by the 1989 Exxon Valdez oil spill. Large resident and migratory seabird populations are sustained by local stocks of key forage fish species. Monitoring of seabird populations and forage fish stocks in potential oil and gas lease areas is a BOEM priority, both to mitigate the impacts of development and to assess the impact of potential oil spills. In 2016, the USGS initiated new studies to update knowledge gained from seabird and forage fish studies in lower Cook Inlet from 1995 to 2000, in advance of potential lease sales and associated activities in Cook Inlet during 2017 and beyond. These studies are also assessing change in seabird and fish populations following anomalous high temperatures in 2014-16.

\section{Contact}

John Piatt, USGS Alaska Science Center, jpiatt@usgs.gov, (360) 774-0516

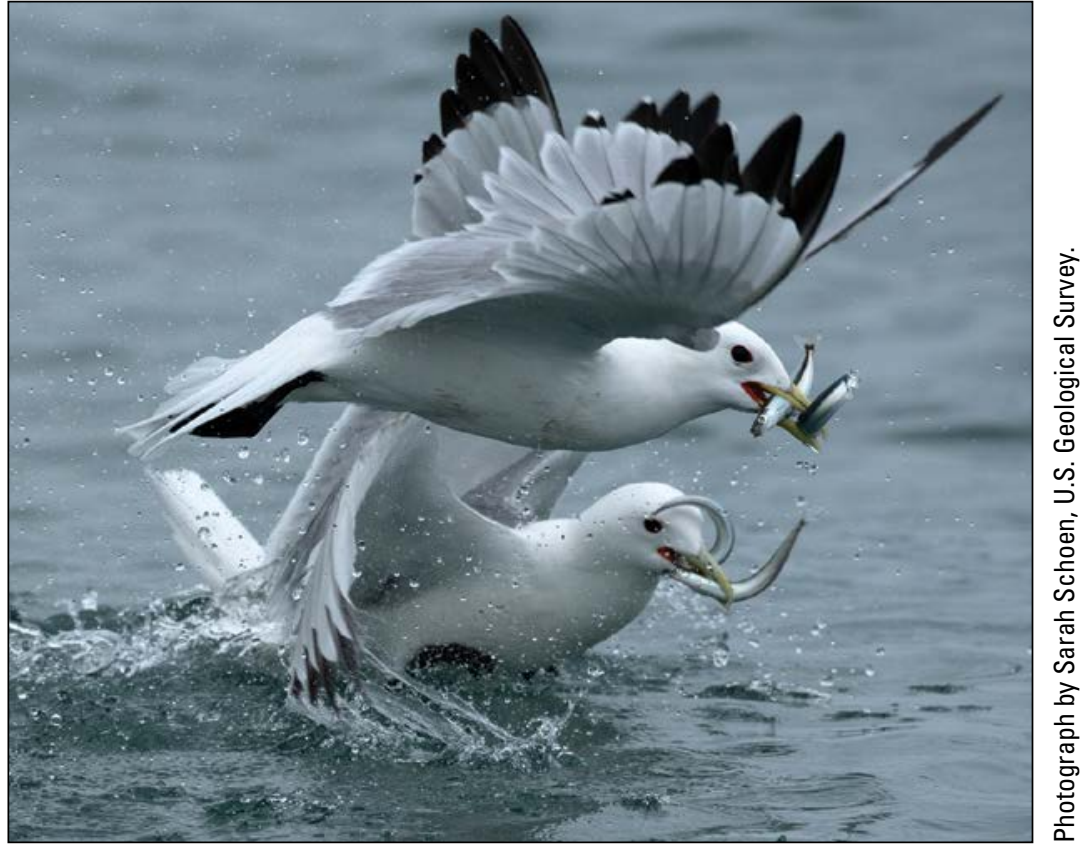

Black-legged Kittiwakes forage on Pacific sand lance and capelin near their colony on Gull Island, Cook Inlet, Alaska.

\section{Atlantic Ocean}

\section{Satellite Tracking Offshore Habitat Use in Diving Birds}

In collaboration with BOEM, USFWS, and other partners, USGS scientists are using platform terminal transmitter satellite tracking tags to determine the occurrence and local movement patterns of red-throated loons, surf scoters, and northern gannets in U.S. waters of the mid-Atlantic region during migration and winter. From 2012 to 2016, scientists tracked the movements of 75 gannets and 66 loons, and from 2001 to 2016, scientists tracked 217 scoters on their northward migration to breeding colonies and on their southward migration back to and through the mid-Atlantic region. Data can be used to inform siting, permitting, and regulation of future offshore wind development and can provide important information on key habitat use and migration of a suite of species with different ecological niches.

\section{Contact}

Alicia M. Berlin, USGS Patuxent Wildlife Research Center, aberlin@usgs.gov, (301) 497-5730

\section{Publication}

Spiegel, C.S., Berlin, A.M., Gilbert, A.T., Gray, C.O., Montevecchi, W.A., Stenhouse, I.J., Ford, S.L., Olsen, G.H., Fiely, J.L., Savoy, L., Goodale, M.W., and Burke, C.M., 2017, Determining fine-scale use and movement patterns of diving bird species in Federal waters of the Mid-Atlantic United States using satellite telemetry: Sterling, Va., Bureau of Ocean Energy Management Office of Renewable Energy, OCS Study BOEM 2017-069, 260 p., https://pubs.er.usgs.gov/publication/70194432. 


\section{External GPS-GSM Transmitters for Tracking Seabirds}

USGS scientists are testing solar-powered GPS-GSM transmitters on seabirds to capture fine-scale movement patterns and better relate the influence of weather, resource availability, and hazardous conditions on seabirds. These transmitters are providing data on flight altitude of seabirds, information that is relevant to assessing the risk of collision or displacement to seabirds by potential offshore wind turbines. This information can be used to model habitat use, mortality risk, and the impact of weather on flight behavior for these species regarding multiple proposed offshore wind facilities along the Atlantic coast.

\section{Contact}

Alicia M. Berlin, USGS Patuxent Wildlife Research Center, aberlin@usgs.gov, (301)497-5730

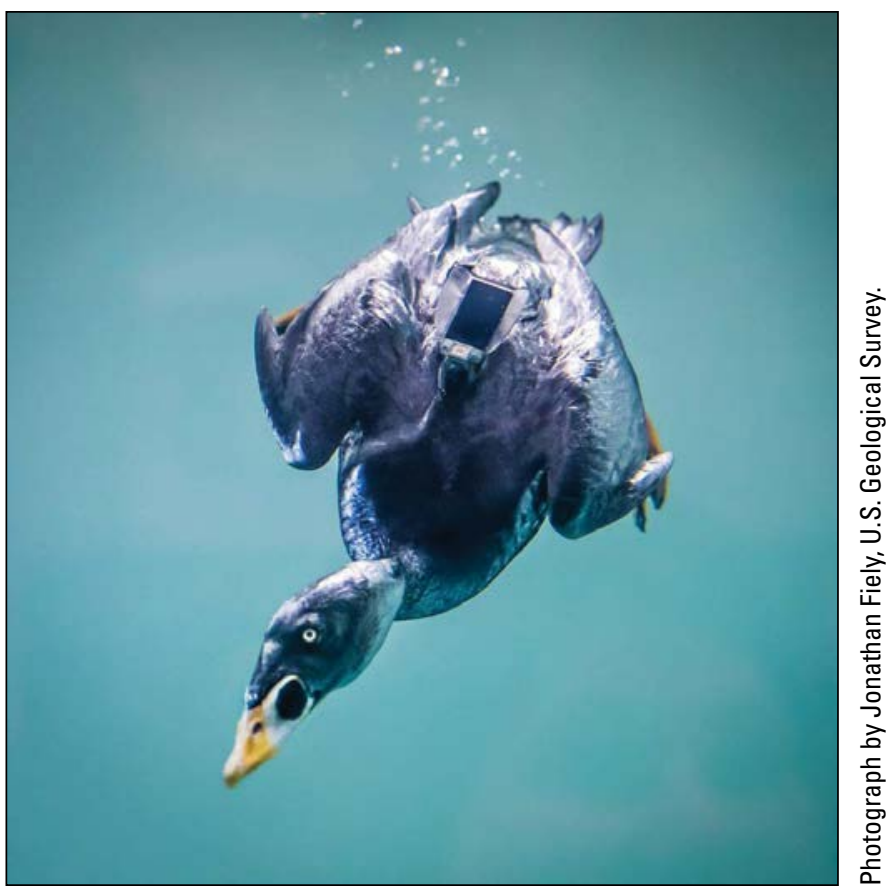

Diving male surf scoter with a newly designed GPS-GSM transmitter.

\section{Potential Impacts of Offshore Wind Energy Projects on Endangered Roseate Terns}

Offshore wind energy projects are being proposed and developed off the coasts of Massachusetts and New York, with the first project becoming operational at Block Island, off the coast of Rhode Island. Fish-eating terns traveling through these areas could be affected by the construction and operation of wind turbines. The Cape and Islands area of southeastern Massachusetts is a particularly important area for the endangered northwest Atlantic roseate tern because most of the population congregates in this area for several months during the post-breeding staging period prior to fall migration. USGS scientists are examining long-term temporal variation in staging site use and survival of terns prior to the construction of offshore wind turbines. These data could be useful for evaluating the timing of risks to roseate terns from proposed offshore wind energy projects.

\section{Contacts}

Jeffrey Spendelow, Emeritus, USGS Patuxent Wildlife Research Center, jspendelow@usgs.gov, (301) 497-5665

Mark Wimer, USGS Patuxent Wildlife Research Center, mwimer@usgs.gov, (301) 497-5596

\section{Publications}

Althouse, M.A., Cohen, J.B., Karpanty, S.M., Spendelow, J.A., Davis, K.L., Parsons, K.C., and Luttazi, C.F., 2019, Evaluating response distances to develop buffer zones for staging terns: Journal of Wildlife Management, v. 83, no. 2, p. 260-271, https://doi.org/10.1002/jwmg.21594.

Althouse, M.A., Cohen, J.B., Spendelow, J.A., Karpanty, S.M., Davis, K.L., Parsons, K.C., and Luttazi, C.F., 2016, Quantifying the effects of research band resighting activities on staging terns in comparison to other disturbances: Waterbirds, v. 39, no. 4, p. 417-421, https://doi.org/10.1675/063.039.0412.

Davis, K.L., Karpanty, S.M., Spendelow, J.A., Cohen, J.B., Althouse, M.A., Parsons, K.C., and Luttazi, C.F., 2019, Begging behavior as an honest signal of need and parent-offspring association during the post-fledging dependency period: Ecology and Evolution, v. 9, no. 13, p. 7497-7508, https://doi.org/10.1002/ece3.5279.

Nichols, J.M., Spendelow, J.A., and Nichols, J.D., 2017, Using optimal transport theory to estimate transition probabilities in metapopulation dynamics: Ecological Modelling, v. 349, p. 311-319, https://doi.org/10.1016/j.ecolmodel.2017.06.003.

Nisbet, I.C.T., Monticelli, D., Spendelow, J.A., and Szczys, P., 2016, Pre-breeding survival of roseate terns Sterna dougallii varies with sex, hatching order and hatching date: Ibis, v. 158, no. 2, p. 327-334, https://doi.org/10.1111/ibi.12359. 
Spendelow, J.A., 2017, Rapid 3-week transition from migration to incubation in a female roseate tern (Sterna dougallii): North American Bird Bander, v. 42, no. 3, p. 62-64, https://pubs.er.usgs.gov/publication/70194706.

Spendelow, J.A., 2018, Roseate tern use of staging sites in the Northeastern United States, in Macleod-Nolan, C., comp., Annual Roseate Tern Newsletter 2017 (no. 11. April 2018): Bedfordshire, England, Roseate Tern LIFE Project, p. 59-65, http://roseatetern.org/news/annual-roseate-tern-newsletter-2017.

Spendelow, J.A., 2019, 2018 roseate tern staging site research in the Northeast United States, in Macleod-Nolan, C. comp., Annual Roseate Tern Newsletter 2018 (no. 12. March 2019): Royal Society for the Protection of Birds, Bedfordshire, England, Roseate Tern LIFE Project, p. 49-52.

Spendelow, J.A., and Eichenwald, A.J., 2018, Post spring migration colony-site prospecting by roseate terns (Sterna dougallii): North American Bird Bander, v. 43, no. 1, p. 1-6, https://pubs.er.usgs.gov/publication/70198082.

Spendelow, J.A., and Eichenwald, A.J., 2018, Rapid departure of roseate terns (Sterna dougallii) following large-scale nest failure: Wilson Journal of Ornithology, v. 130, no. 2, p. 485-492, https://doi.org/10.1676/17-017.1.

Spendelow, J.A., and Lugo, G., 2017, First evidence that paired roseate terns travel together during spring migration: North American Bird Bander, v. 42, no. 3, p. 60-62, https://pubs.er.usgs.gov/publication/70194705.

\section{Spatial and Foraging Ecology of Brown Pelicans in the South Atlantic Bight}

Brown pelicans are a species of concern in many States and can serve as an indicator species for marine, coastal, and estuarine ecosystem health because they interact with all three ecosystems and across a range of trophic systems. There is potential overlap between pelican use areas and proposed or existing BOEM activities around development of offshore wind, oil, or gas. Information about the fine-scale habitat use of brown pelicans in the marine environment is needed to determine the probability of pelican exposure to offshore energy development activities. USGS scientists are attaching GPS tags to pelicans in South Carolina, Georgia, and northeastern Florida to assess foraging ranges, movement patterns, and migration paths. This research also complements pelican tracking efforts being conducted in the Gulf of Mexico (GOM).

\section{Contact}

Patrick Jodice, USGS South Carolina Cooperative Fish and Wildlife Research Unit, pjodice@clemson.edu, (864) 656-6190

\section{Additional Resources}

\section{Modeling of Atlantic Coast Seabird Distributions}

Flanders, N.P., Gardner, B., Winiarski, K.J., Paton, P.W.C., Taber, A., and O’Connell, A.F., 2015, Key seabird areas in southern New England identified using a community occupancy model: Marine Ecology Progress Series, v. 533, p. 277-290, https://doi.org/10.3354/meps11316.

Zipkin, E.F., Kinlan, B.P., Sussman, A., Rypkema, D., Wimer, M., and O'Connell, A.F., 2015, Statistical guidelines for assessing marine avian hotspots and coldspots - A case study on wind energy development in the U.S. Atlantic Ocean: Biological Conservation, v. 191, November, p. 216-223, https://doi.org/10.1016/j.biocon.2015.06.035.

\section{The Atlantic Offshore Seabird Dataset Catalog}

Wimer, M., and Benson, A., 2016, USGS Patuxent Wildlife Research Center Seabirds Compendium, ver. 1.1: U.S. Geological Survey dataset, https://www1.usgs.gov/obis-usa/ipt/resource?r=usgs_pwrc_seabirdscompendium\&v=1.1.

\section{Diving Bird Acoustic Sensitivity Studies}

Crowell, S.E., Wells-Berlin, A.M., Carr, C.E., Olsen, G.H., Therrien, R.E., Yannuzzi, S.E., and Ketten, D.R., 2015, A comparison of auditory brainstem responses across diving bird species: Journal of Comparative Physiology A, v. 201, no. 8, p. 803-815, https://doi.org/10.1007/s00359-015-1024-5.

Crowell, S.E., Wells-Berlin, A.M., Therrien, R.E., Yannuzzi, S.E., and Carr, C.E., 2016, In-air hearing of a diving duck-A comparison of psychoacoustics and auditory brainstem response thresholds: Journal of the Acoustical Society of America, v. 139, no. 5, p. 3001-3008, https://doi.org/10.1121/1.4948574. 


\section{Great Lakes}

\section{Distribution, Abundance, and Movement of Waterbirds on Lake Michigan}

USGS scientists have surveyed pelagic bird use in areas of Lake Michigan during fall and winter periods over 4 years to determine distribution patterns and abundance in nearshore and open water areas for the common loon, red-throated loon, white-winged scoter, black scoter, surf scoter, long-tailed duck, common merganser, red-breasted merganser, red-necked grebe, horned grebe, greater scaup, lesser scaup, and other waterbirds. Efforts are now focused on developing spatially explicit distribution models from aerial survey data of selected waterbirds on Lake Michigan. In addition, satellite telemetry has been used to document movement and habitat use of common loons during migration across the Great Lakes and long-tailed ducks while wintering on Lake Michigan. These data on waterbird seasonal movement patterns and core use areas can be used to inform environmental impact assessments of potential wind turbine placement and

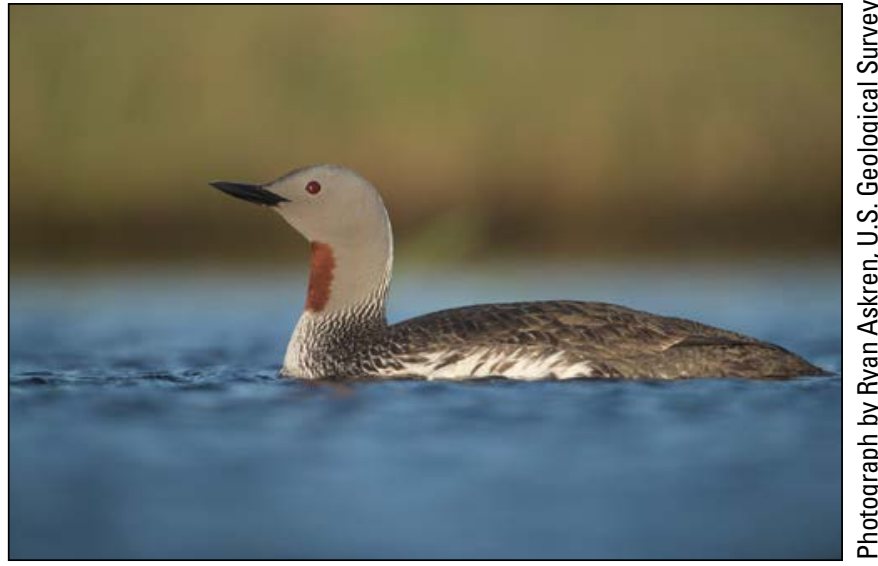

Red-throated loon. assist resource managers with energy development planning and siting decisions.

\section{Contact}

Kevin P. Kenow, USGS Upper Midwest Environmental Sciences Center, kkenow@usgs.gov, (608) 781-6278

\section{Publications}

Fara, L.J., 2018, Migration patterns, habitat use, prey items, and hunter harvest of long-tailed ducks (Clangula hyemalis) that overwinter on Lake Michigan: Carbondale, Ill., Southern Illinois University, M.S. thesis, 92 p., https://opensiuc.lib.siu.edu/ cgi/viewcontent.cgi? article $=3428 \&$ context $=$ theses.

Kenow, K.P., Houdek, S.C., Fara, L.J., Gray, B.R., Lubinski, B.R., Heard, D.J., Meyer, M.W., Fox, T.J., and Kratt, R.J., 2018, Distribution and foraging patterns of common loons on Lake Michigan with implications for exposure to type E avian botulism: Journal of Great Lakes Research, v. 44, no. 3, p. 497-513, https://doi.org/10.1016/j.jglr.2018.02.004.

Sussman, A.L., Gardner, B., Adams, E.M., Salas, L., Kenow, K.P., Luukkonen, D.R., Monfils, M.J., Mueller, W.P., Williams, K.A., Leduc-Lapierre, M. and, Zipkin, E.F., 2019, A comparative analysis of common methods to identify waterbird hotspots: Methods in Ecology and Evolution, early view posted May 11, 2019, 15 p., https://doi.org/10.1111/2041-210X.13209.

\section{Gulf of Mexico}

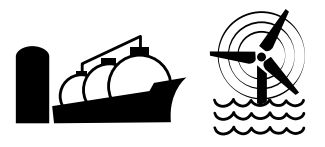

\section{Distribution of Landbirds During Migratory Stopover in the Gulf of Mexico Region}

Each spring and fall, millions of landbirds migrate through the GOM region and depend on stopover sites for food and cover. In areas along the northern and western Gulf, where development of liquefied natural gas export terminals is increasing, it is critical in conservation planning efforts to know where birds consistently stop to rest and forage. In support of the USFWS, the USGS is using weather surveillance radar from 2008 to 2015 to quantify the stopover distribution of landbirds during spring and fall migrations. The USFWS can use these data to inform environmental assessments of energy projects, such as liquefied natural gas export terminals, pipelines, and wind turbines, and other development, such as cellular towers and roads.

\section{Contact}

Wylie C. Barrow, Jr., USGS Wetland and Aquatic Research Center, barroww@usgs.gov, (337) 266-8668 


\section{Spatial and Reproductive Ecology of Brown Pelicans in the Gulf of Mexico}

The GOM contains a high density of oil infrastructure and a rich assemblage of seabirds, yet at-sea distribution and habitat use of seabirds are poorly understood. The brown pelican is a focal species for studies about risk exposure in the marine environment because of its distribution, behavior, and known sensitivity to chemical and oil contaminants. To assist the USFWS, BOEM, State agencies, and the Gulf of Mexico Avian Monitoring Network in developing management plans and future research and monitoring efforts, the USGS is studying colony-specific movement patterns, habitat use at sea, and reproduction for brown pelicans. Movement data collected using GPS satellite tags on 85 adult pelicans breeding in the region can help resource managers assess the spatial ecology of the brown pelican.

\section{Contact}

Patrick Jodice, USGS South Carolina

Cooperative Fish and Wildlife Research Unit, pjodice@clemson.edu, (864)656-6190

\section{Publications}

Lamb, J.S., Satgé, Y.G., Fiorello, C.V., and Jodice, P.G.R., 2017, Behavioral and reproductive effects of bird-borne data logger attachment on brown pelicans (Pelecanus occidentalis) on three temporal scales: Journal of Ornithology, v. 158, no. 2, p. 617-627, https://doi.org/10.1007/s10336016-1418-3.

Lamb, J.S., Satgé, Y.G., and Jodice, P.G.R., 2017, Diet composition and provisioning rates of nestlings determine reproductive success in a subtropical seabird: Marine Ecology Progress Series, v. 581, p. 149-164, https://doi.org/10.3354/meps12301.

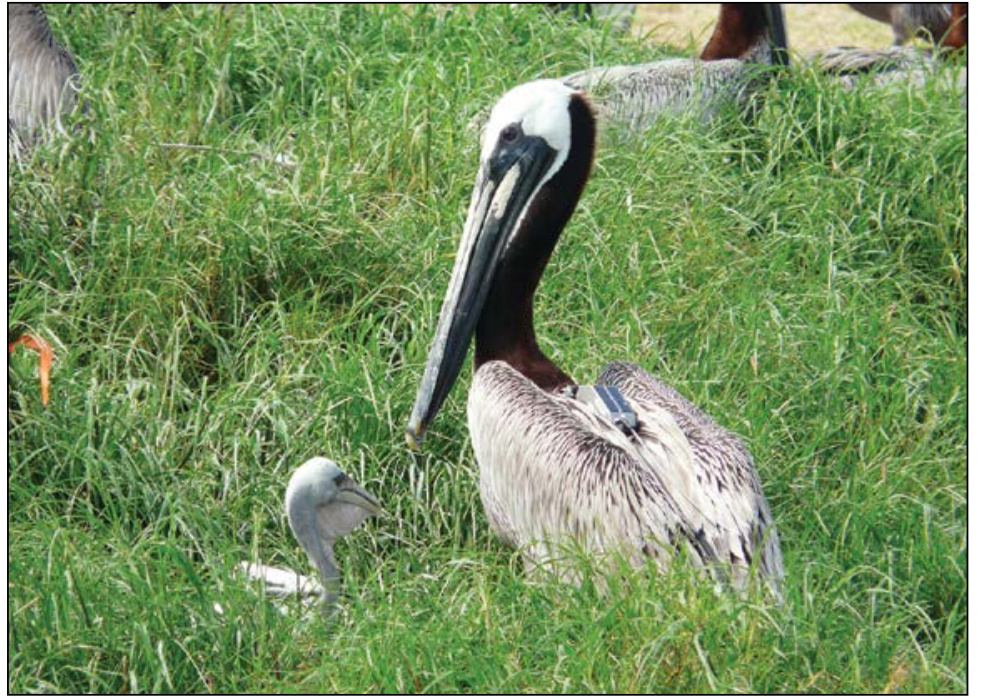

Brown pelican with chick.

\section{Pacific Ocean}

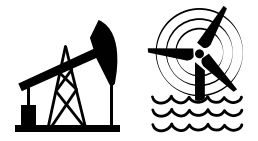

\section{Pacific Marine Bird and Mammal Research and Monitoring Programs}

The USGS and partners have gathered information about marine bird and mammal research and monitoring programs into an online database to support environmental risk assessments for species and habitats sensitive to offshore energy activities in the southern California and Washington-Oregon Planning Areas and the Hawaiian Outer Continental Shelf (OCS) of BOEM. The database includes information from programs that assessed distribution, abundance, and biology of marine birds, such as seabirds, waterbirds, sea ducks, or shorebirds, and marine mammals, such as cetaceans, pinnipeds, or sea otters. Much of the information focuses on species protected under the Endangered Species or Marine Mammal Protection Acts. This database can be easily updated as new information becomes available.

\section{Contact}

Josh Adams, USGS Western Ecological Research Center, josh_adams@usgs.gov, (831) 460-7566

\section{Publication}

Adams, J., Lafferty, K.D., Kelsey, E.C., and Johnston, C.A., 2019, Synopsis of research programs that can provide baseline and monitoring information for offshore energy activities in the Pacific region-Seabird and marine mammal surveys in the Pacific region: Camarillo, Calif., U.S. Department of the Interior, Bureau of Ocean Energy Management, OCS Study BOEM 2019-042, prepared under BOEM Intra-Agency Agreement no. M14PG00039, 54 p., https://www.boem.gov/2019-042/. 


\section{Southern California Marine Bird and Mammal Surveys}

The Southern California Bight and the Pacific OCS biome provide habitat for numerous migratory, resident, and breeding species of seabirds and marine mammals. Multiple wind energy projects have been proposed for this region, which supports important regional populations of several species, including black storm-petrel, brown pelican, Scripps's murrelet, elegant tern, and approximately one-half of the world population of endemic ashy storm-petrels. In partnership with BOEM, the USGS is conducting aerial photographic surveys of the ocean off central and southern California and developing new methods that use machine learning algorithms to detect seabirds and marine mammals in images. Automating detection and counts can allow researchers to generate comprehensive, quantitative data on species composition, distribution, abundance, habitat associations, and seasonal variation of seabirds and marine mammals from imagery. This project builds upon aerial and ship-based observational surveys conducted throughout the Pacific OCS over the past 40 years, and current data will be related to historic data to inform the permitting and planning process for offshore wind development.
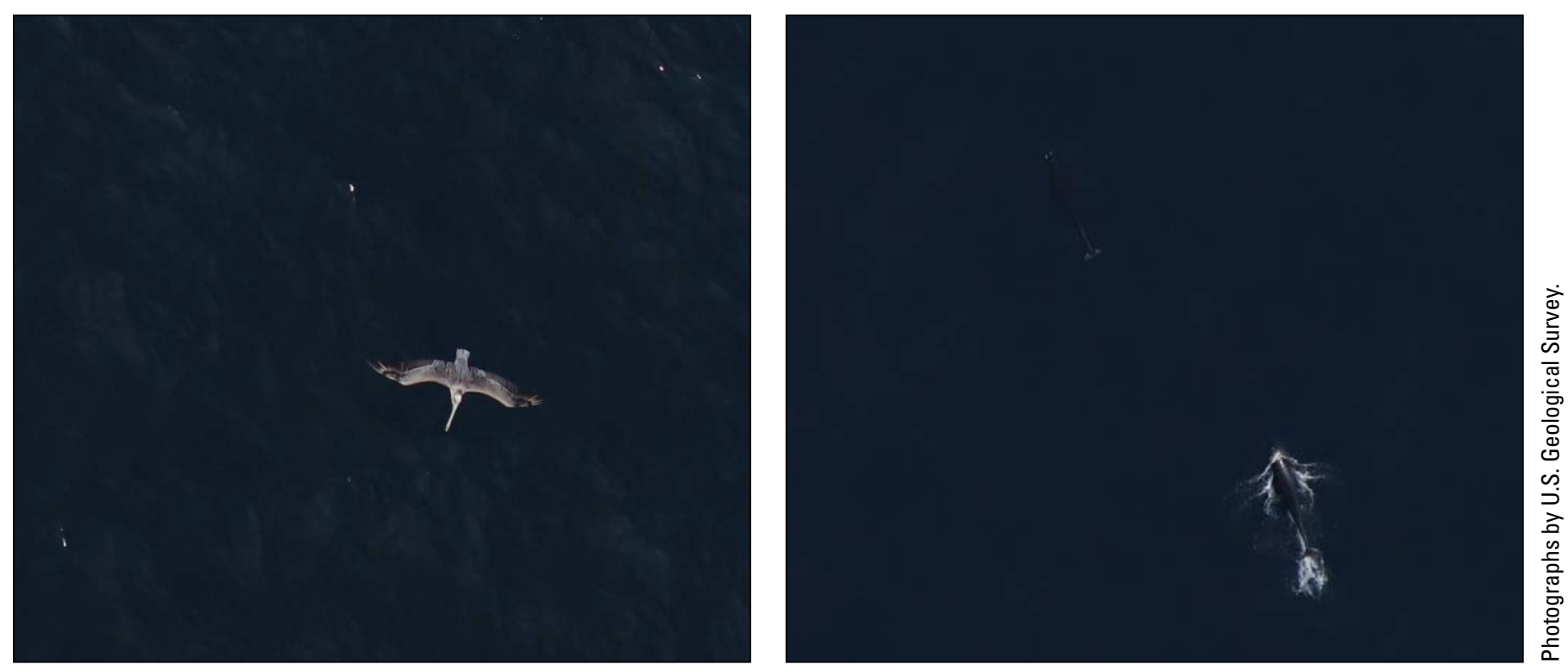

Photographs captured during an aerial survey showing (left) a California brown pelican and (right) two northern right whale dolphins.

\section{Contact}

Josh Adams, USGS Western Ecological Research Center, josh_adams@usgs.gov, (831) 460-7566

\section{Publications}

Adams, J., Felis, J.J., Mason, J.W., and Takekawa, J.Y., 2015, Pacific Continental Shelf Environmental Assessment (PaCSEA) GIS resource database - Aerial seabird and marine mammal surveys off northern California, Oregon, and Washington, 2011-2012: U.S. Geological Survey data release, https://doi.org/10.5066/F7668B7V.

Adams, J., Kelsey, E.C., Felis, J.J., and Pereksta, D.M., 2017, Collision and displacement vulnerability among marine birds of the California Current System associated with offshore wind energy infrastructure (ver. 1.1, July 2017): U.S. Geological Survey Open-File Report 2016-1154, 116 p., https://doi.org/10.3133/ofr20161154.

Kelsey, E.C., Felis, J.J., Czapanskiy, M., Pereksta, D.M., and Adams, J., 2018, Collision and displacement vulnerability to offshore wind energy infrastructure among marine birds of the Pacific Outer Continental Shelf: Journal of Environmental Management, v. 227, p. 229-247, https://doi.org/10.1016/j.jenvman.2018.08.051.

Takekawa, J.Y., Perry, W.M., Adams, J., Felis, J.J., Williams, L.L., Yee, J.L., Orthmeyer, D.L., Mason, J.W., McChesney, G.J., McIver, W.R., Carter, H.R., and Golightly, R.T., 2017, At-sea distribution and abundance of seabirds and marine mammals off southern California GIS resource database-Aerial seabird and marine mammal surveys off southern California, 1999-2002: U.S. Geological Survey data release, https://doi.org/10.5066/F7PK0D9P. 


\section{Predictive Modeling of Marine Bird Distributions on the Pacific Outer Continental Shelf}

California, Oregon, and Washington are engaged with BOEM and the National Oceanic and Atmospheric Administration (NOAA) to plan the siting of offshore energy projects within the territorial sea and Pacific OCS regions. The USGS and collaborators are using historic, aerial- and vessel-based, transect survey data coupled with oceanographic and environmental data to develop predictive models of marine bird distributions and relative density. These data can be used to map areas of high or low relative bird abundance throughout a large region of the California Current System, helping Pacific OCS States and BOEM evaluate areas in advance of future energy development.

\section{Contact}

Josh Adams, USGS Western Ecological Research Center, josh_adams@usgs.gov, (831) 460-7566

\section{Main Hawaiian Islands Breeding Seabird Atlas}

The main Hawaiian Islands (MHI) and associated offshore areas provide substantial breeding habitat for more than 19 native seabird species that spend the majority of their lives at sea and use these waters for foraging, resting, and commuting. Offshore areas surrounding the MHI have been proposed for wind energy-related projects that have the potential to negatively affect seabirds through interactions with wind-turbine structures, lighted facilities, elevated power lines on land, and lighted ships offshore. BOEM and other Federal, State, and local resource managers overseeing offshore renewable energy development within the waters surrounding the MHI require comprehensive, quantitative data of seabird colony locations, colony extents, and breeding population sizes to inform siting, conservation, and mitigation actions for affected species. The USGS and partners are working on a comprehensive atlas of MHI seabird colonies that can be used to generate predictions of at-sea distributions among seabirds on the basis of colony size and location, central-place foraging theory, and new empirical data from at-sea ranging studies throughout the MHI. The atlas can provide benchmarks to measure future changes in seabird population sizes and breeding distribution and can also assist efforts to evaluate threats to seabirds both on land and at sea.

\section{Contact}

Josh Adams, USGS Western Ecological Research Center, josh_adams@usgs.gov, (831) 460-7566

\section{Main Hawaiian Islands Seabird Tracking}

As of January 2017, the State of Hawai'i's alternative energy policy mandates and Federal interest in developing offshore renewable energy resources have prompted unsolicited lease requests to BOEM for offshore wind energy infrastructure in ocean waters off Hawai' $i$. The MHI support important seabird breeding populations that could be vulnerable to offshore wind energy infrastructure. The USGS assessed at-sea ranging behaviors among seabirds to provide new information on breeding seabird distribution at sea, habitat utilization, and ranging behaviors within near-island waters and throughout OCS waters surrounding the MHI. USGS scientists examined the at-sea distributions and ranging behaviors of five abundant breeding species in the MHI: brown booby, red-footed booby, red-tailed tropicbird, Laysan albatross, and wedge-tailed shearwater. From 2013 to 2016, scientists studied 1,128 breeding individuals of these species from 14 sites throughout the MHI by using GPS loggers and time-depth recorders; study colonies were on the islands of Maui, $\mathrm{O}^{\prime}$ ahu, Kaua ' $\mathrm{i}$, and associated islets. Data from this study can inform BOEM and State of Hawai' $i$ decisions regarding offshore wind energy development.

\section{Contact}

Josh Adams, USGS Western Ecological Research Center, josh adams@usgs.gov, (831)460-7566

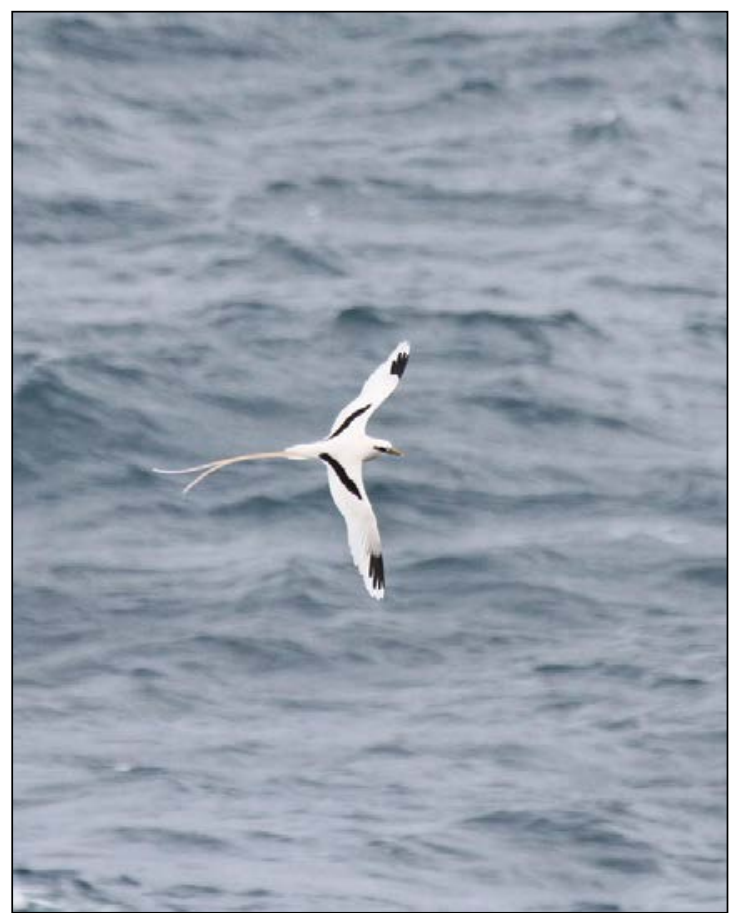

A white-tailed tropicbird flying. 


\section{Seabird and Marine Mammal Aerial Surveys Off Northern California, Oregon, and Washington}

During 2011 and 2012, the USGS partnered with BOEM to complete the Pacific Continental Shelf Environmental Assessment (PaCSEA), which included replicated marine bird and mammal surveys from the shore over the continental shelf and slope along 32 broad-scale transects from northern California to Washington State. Additionally, finer scale surveys were conducted over the continental shelf within six designated areas of interest to BOEM: Fort Bragg, California; Eureka, California; Siltcoos Bank, Oregon; Newport, Oregon; Nehalem Bank, Oregon; and Grays Harbor, Washington. Synchronous tracking data were collected for one of the most abundant species in the region, common murre, to evaluate how survey and tracking data can inform marine spatial planning in complementary ways. Tracking data have revealed how the species adjusts its diving behavior when faced with anomalous ocean conditions. These data provide updated distribution, abundance, and behavior information on seabirds and marine mammals for potential offshore renewable energy development in the region.

\section{Contact}

Josh Adams, USGS Western Ecological Research Center, josh_adams@usgs.gov, (831) 460-7566

\section{Publications}

Adams, J., Felis, J.J., Mason, J.W., and Takekawa, J.Y., 2016, Pacific Continental Shelf Environmental Assessment (PaCSEA) GIS resource database-Aerial seabird and marine mammal surveys off northern California, Oregon, and Washington, 2011-2012: U.S. Geological Survey data release, https://doi.org/10.5066/F7668B7V.

Loredo, S.A., Orben, R.A., Suryan, R.M., Lyons, D.E., Adams, J., and Stephensen, S.W., 2019, Spatial and temporal diving behavior of non-breeding common murres during two summers of contrasting ocean conditions: Journal of Experimental Marine Biology and Ecology: v. 517, p. 13-24, https://doi.org/10.1016/j.jembe.2019.05.009.

Phillips, E.M., Horne, J.K., Adams, J., and Zamon, J.E., 2018, Selective occupancy of a persistent yet variable coastal river plume by two seabird species: Marine Ecology Progress Series, v. 594, p. 245-261, https://doi.org/10.3354/meps12534.

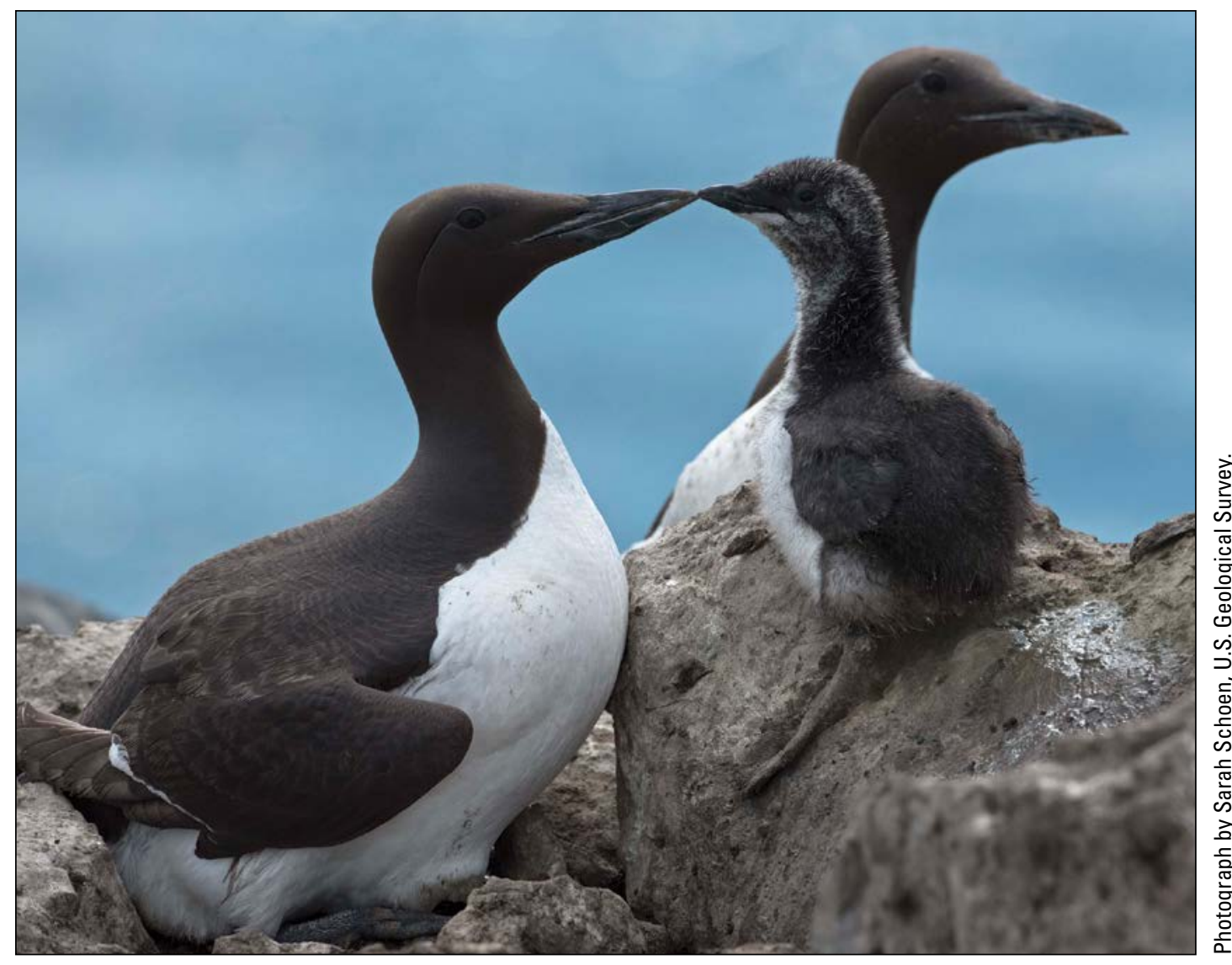

Common murres in Cook Inlet, Alaska. 


\section{Seabird Vulnerability Assessment for Renewable Energy Projects on the Pacific Outer Continental Shelf}

In partnership with BOEM, the USGS quantified collision and displacement vulnerability to offshore wind energy development for 81 marine bird species common to the California Current System portion of the Pacific OCS. The vulnerability values generated for these bird species were based on life history traits, population size, demography, habitat use, disturbance sensitivity, and conservation status. The vulnerability values generated in this assessment can be used by resource managers to evaluate potential impacts associated with the construction and long-term operation of offshore wind energy infrastructure.

\section{Contact}

Josh Adams, USGS Western Ecological Research Center, josh_adams@usgs.gov, (831) 460-7566

\section{Publications}

Adams, J., Kelsey, E.C., Felis, J.J. and Pereksta, D.M., 2017, Collision and displacement vulnerability among marine birds of the California Current System associated with offshore wind energy infrastructure (ver. 1.1, July 2017): U.S. Geological Survey Open-File Report 2016-1154, 116 p., https://doi.org/10.3133/ofr20161154.

Adams, J., Kelsey, E.C., Felis J.J., and Pereksta, D.M., 2017, Data for calculating population, collision and displacement vulnerability among marine birds of the California Current System associated with offshore wind energy infrastructure (ver. 2.0, June 2017): U.S. Geological Survey data release, https://doi.org/10.5066/F79C6VJ0.

Kelsey, E.C., Felis, J.J., Czapanskiy, M., Pereksta, D.M., and Adams, J., 2018, Collision and displacement vulnerability to offshore wind energy infrastructure among marine birds of the Pacific Outer Continental Shelf: Journal of Environmental Management, v. 227, p. 229-247, https://doi.org/10.1016/j.jenvman.2018.08.051.

\section{Additional Publications}

Fallon, J.A., Smith, E.P., Schoch, N., Paruk, J.D., Adams, E.A., Evers, D.C., Jodice, P.G.R., Perkins, C., Schulte, S., and Hopkins, W.A., 2018, Hematological indices of injury to lightly oiled birds from the Deepwater Horizon oil spill: Environmental Toxicology and Chemistry, v. 37, no. 2, p. 451-461, https://doi.org/10.1002/etc.3983.

Haney, J.C., Jodice, P.G.R., Montevecchi, W.A., and Evers, D.C., 2017, Challenges to oil spill assessment for seabirds in the deep ocean: Archives of Environmental Contamination and Toxicology, v. 73, no. 1, p. 33-39, https://doi.org/10.1007/s00244016-0355-8.

Lamb, J.S., Fiorello, C.V., Satgé, Y.G., Mills, K., Ziccardi, M., and Jodice, P.G.R., 2018, Movement patterns of California brown pelicans (Pelecanus occidentalis californicus) following oiling and rehabilitation: Marine Pollution Bulletin, v. 131, pt. A, p. 22-31, https://doi.org/10.1016/j.marpolbul.2018.03.043.

Lamb, J.S., Newstead, D.J., Koczur, L.M., Ballard, B.M., Green, M.C., and Jodice, P.G.R., 2018, A bridge between oceansOverland migration of marine birds in a wind energy corridor: Journal of Avian Biology, v. 49, no. 2, e01474, p. 1-9, https://doi.org/10.1111/jav.01474.

Pearce, J.M., Flint, P.L., Atwood, T.C., Douglas, D.C., Adams, L.G., Johnson, H.E., Arthur, S.M., and Latty, C.J., 2018, Summary of wildlife-related research on the coastal plain of the Arctic National Wildlife Refuge, Alaska, 2002-17: U.S. Geological Survey Open-File Report 2018-1003, 27 p., https://doi.org/10.3133/ofr20181003. 


\section{Marine Animals and Offshore Energy}

BOEM is responsible for leasing and development activities in the OCS related to energy and mineral resources and therefore requires baseline information and scientific studies on the effects of industrial activities on biological, environmental, and cultural resources for its leasing and management decisions. USGS scientists support BOEM's environmental science priorities by providing science to help assess, predict, monitor, and manage environmental impacts on marine biota and the human, marine, and coastal environments. In Alaska, USGS scientists are studying the distribution, abundance, and behavior of marine mammals, such as the pacific walrus, and marine and diadromous fish in nearshore systems in relation to offshore industrial activities. In the GOM and Atlantic Ocean, research activities are focused on studying manatees and sea turtles in relation to current and potential energy production and mineral extraction and transportation activities. Seafloor mapping and benthic ecosystem studies in the Atlantic and Pacific OCS regions are characterizing novel cold-water corals and seep-associated ecological communities in the deep sea and can inform BOEM decisions regarding the installation, operation, and structural integrity of proposed renewable energy projects.

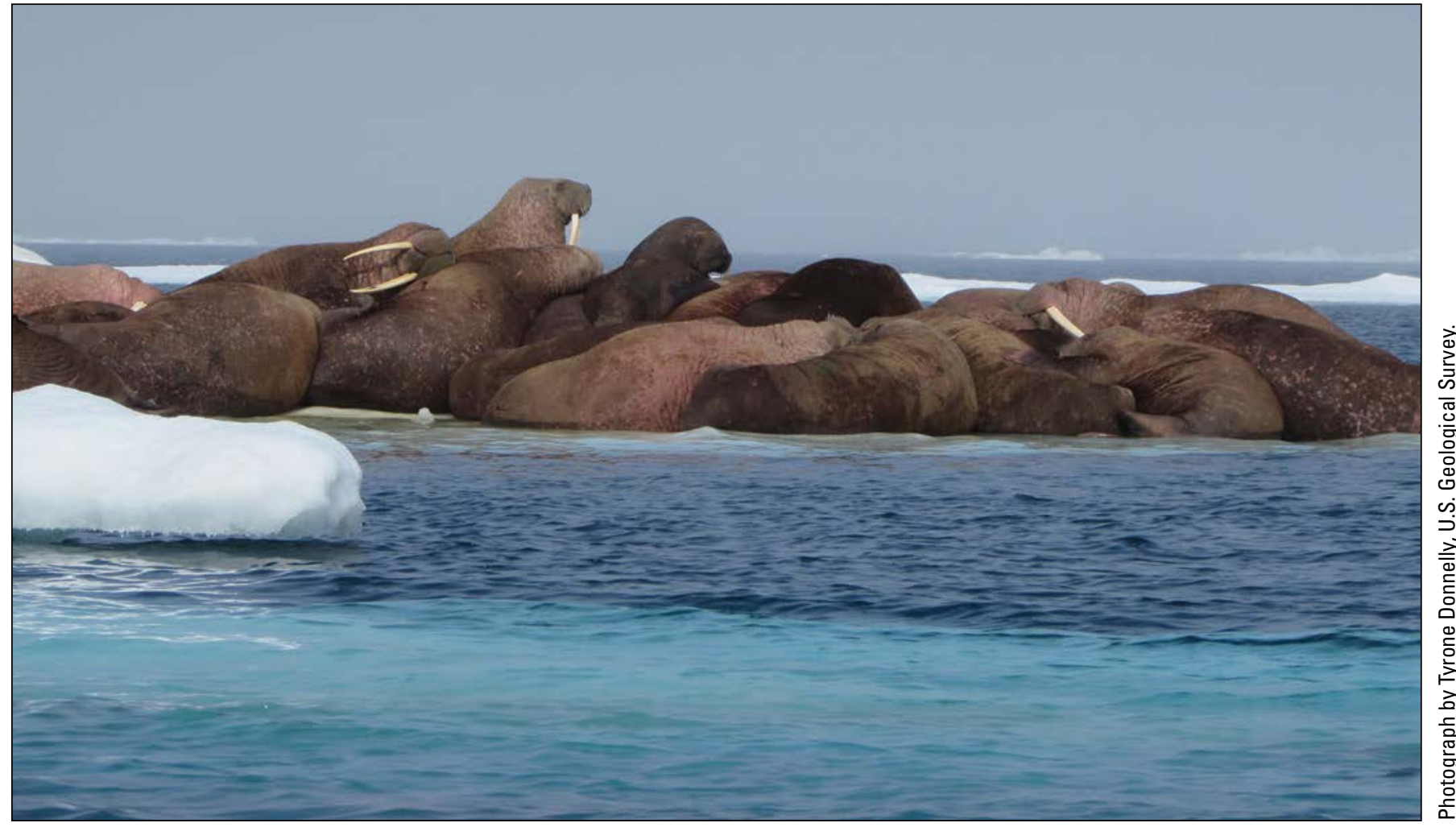

Pacific walrus hauled out on sea ice in the Chukchi Sea.

\section{Alaska}

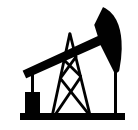

\section{Gulf Watch Alaska Program for Quantifying Coastal Marine Ecosystem Change}

Oil and gas development and transportation activities are major components of Alaska's economy, and some of these activities occur along Alaska's coasts. The USGS is engaged in a collaborative marine monitoring program, Gulf Watch Alaska (https://gulfwatchalaska.org/), which documents the status, variation over time, and underlying drivers of change in Alaska's coastal marine ecosystems. This work quantifies the abundance, distribution, and change in hundreds of marine species, including many of high interest to management agencies. The USGS has been heavily involved in studies documenting the effects of the 1989 Exxon Valdez oil spill on the recovery of the wildlife population. This work provides a context for understanding the potential response of marine ecosystems to energy development relative to other sources of change.

\section{Contact}

Grant V. Hilderbrand, USGS Alaska Science Center, ghilderbrand@usgs.gov, (907) 786-7076 


\section{Publications}

Bodkin, J.L., Coletti, H.A., Ballachey, B.E., Monson, D.H., Esler, D., and Dean, T.A., 2018, Variation in abundance of Pacific blue mussel (M ytilus trossulus) in the northern Gulf of Alaska, 2006-2015: Deep Sea Research Part II-Topical Studies in Oceanography, v. 147, p. 87-97, https://doi.org/10.1016/j.dsr2.2017.04.008.

Bowen, L., Miles, A.K., Ballachey, B., Waters, S., and Bodkin, J., 2016, Gene transcript profiling in sea otters post-Exxon Valdez oil spill—A tool for marine ecosystem health assessment: Journal of Marine Science and Engineering, v. 4, no. 2, 12 p., https://doi.org/10.3390/jmse4020039.

Bowen, L., Miles, A.K., Ballachey, B., Waters, S., Bodkin, J., Lindeberg, M., and Esler, D., 2018, Gene transcription patterns in response to low level petroleum contaminants in M ytilus trossulus from field sites and harbors in southcentral Alaska: Deep Sea Research Part II-Topical Studies in Oceanography, v. 147, p. 27-35, https://doi.org/10.1016/j.dsr2.2017.08.007.

Coletti, H.A., Bodkin, J.L., Monson, D.H., Ballachey, B.E., and Dean, T.A., 2016, Detecting and inferring cause of change in an Alaska nearshore marine ecosystem: Ecosphere, v. 7, no. 10, e01489, 20 p., https://doi.org/10.1002/ecs2.1489.

Esler, D., Ballachey, B.E., Bowen, L., Miles, A.K., Dickson, R.D., and Henderson, J.D., 2016, Cessation of oil exposure in harlequin ducks after the Exxon Valdez oil spill—Cytochrome P4501A biomarker evidence: Environmental Toxicology and Chemistry, v. 36, no. 5, p. 1294-1300, https://doi.org/10.1002/etc.3659.

Esler, D., Ballachey, B.E., Matkin, C., Cushing, D., Kaler, R., Bodkin, J., Monson, D., Esslinger, G., and Kloecker, K., 2018, Timelines and mechanisms of wildlife population recovery following the Exxon Valdez oil spill: Deep Sea Research Part IITopical Studies in Oceanography, v. 147, p. 36-42, https://doi.org/10.1016/j.dsr2.2017.04.007.

von Biela, V.R., Newsome, S.D., Bodkin, J.L., Kruse, G.H., and Zimmerman, C.E., 2016, Widespread kelpderived carbon in pelagic and benthic nearshore fishes: Estuarine, Coastal and Shelf Science, v. 181, p. 364-374, https://doi.org/10.1016/j.ecss.2016.08.039.

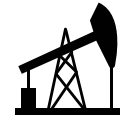

\section{Nearshore Fish Surveys in the Beaufort Sea} that are critic aritical to subsistence fishin in northern Alaska. Rapid changes in physical habitat attributes (for example, temperature and salinity) across the Arctic have led to species range shifts and have likely modified fish assemblages since baseline studies were conducted in the 1980s and 1990s. In 2017, the USGS initiated a new study to update information on nearshore fish communities along the Beaufort Sea coastline in support of planned development and continued oil and gas production. Study sites include coastal lagoons and exposed coastline near Prudhoe Bay and within the Coastal Plain (that is, the 1002 area) of the Arctic National Wildlife Refuge.

\section{Contact}

Vanessa von Biela, USGS Alaska Science Center, vvonbiela@usgs.gov, (907) 786-7073

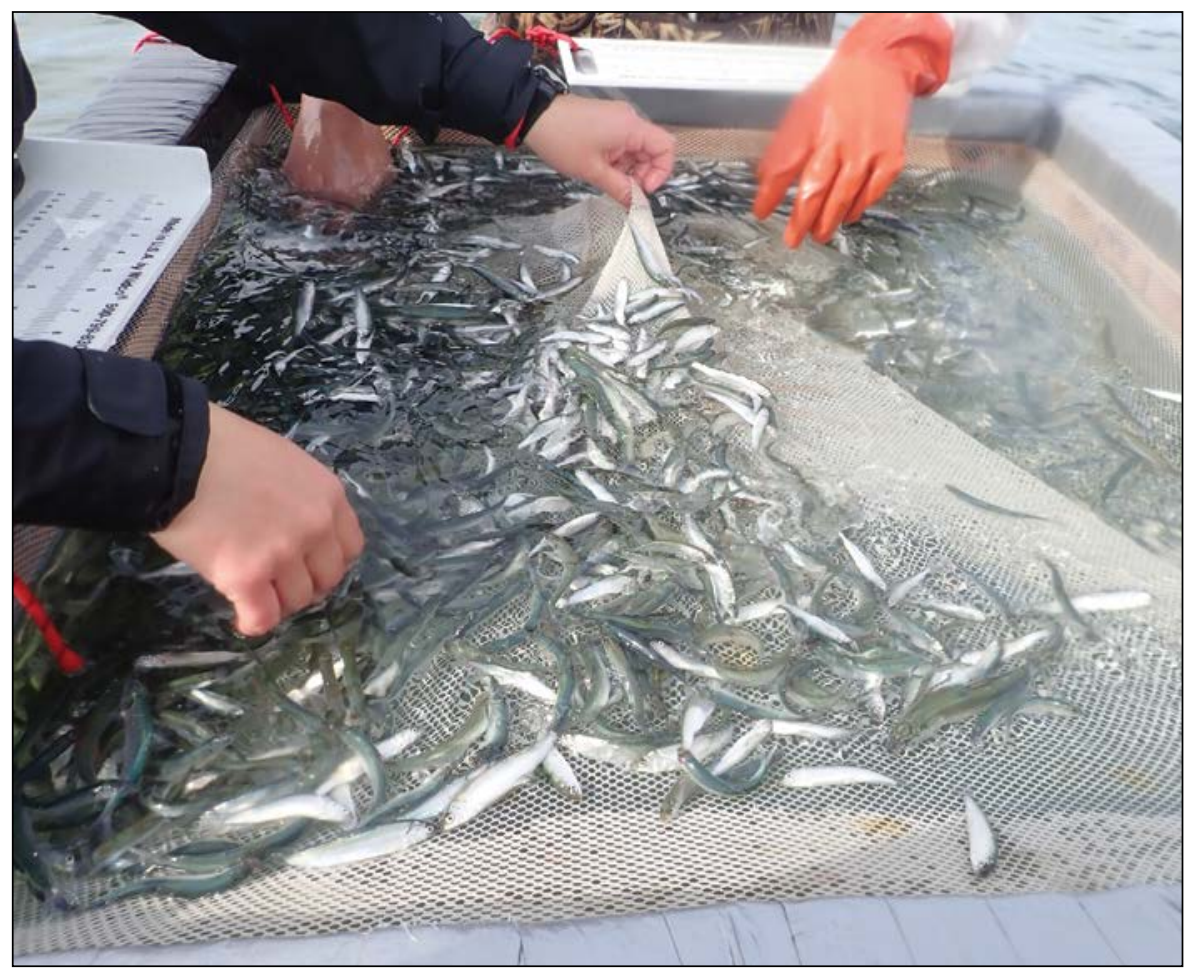

Biologists identify species, count, and measure length of fish to understand how fish use nearshore habitats in Alaska. 


\section{Quantifying the Response of Pacific Walrus to Ocean Noise in the Arctic}

Walruses spend the majority of their time in water, where their underwater acoustic environment enables them to communicate with one another using sound and thus respond to disturbance. USGS scientists are using telemetry data and remote sensing information of sea ice and other environmental variables to study the effects of ocean noise from vessel traffic and offshore industrial activities on Pacific walrus activity patterns. Models are being developed to link levels of activity patterns to walrus energy expenditures and their potential effect on walrus rates of reproduction and survival. The results of these studies can be used to quantify the potential population-level impacts to walruses from offshore oil and gas development and associated support vessels off the coast of arctic Alaska.

\section{Contact}

Grant V. Hilderbrand, USGS Alaska Science Center, ghilderbrand@usgs.gov, (907) 786-7076

\section{Publications}

Beatty, W.S., Jay, C.V., and Fischbach, A.S., 2016, An evaluation of behavior inferences from Bayesian state-space models-A case study with the Pacific walrus: Marine Mammal Science, v. 32, no. 4, p. 1299-1318, https://doi.org/10.1111/mms.12332.

Jay, C.V., Taylor, R.L., Fischbach, A.S., Udevitz, M.S., and Beatty, W.S., 2017, Walrus haul-out and in water activity levels relative to sea ice availability in the Chukchi Sea: Journal of Mammalogy, v. 98, no. 2, p. 386-396, https://doi.org/10.1093/ jmammal/gyw195.

Taylor, R.L., Udevitz, M.S., Jay, C.V., Citta, J.J., Quakenbush, L.T., Lemons, P.R., and Snyder, J.A., 2018, Demography of the Pacific walrus (O dobenus rosmarus divergens) in a changing Arctic: Marine Mammal Science, v. 34, no. 1, p. 54-86, https://doi.org/10.1111/mms.12434.

\section{Distribution and Abundance of Pacific Walrus in Relation to Offshore Development in Alaska}

Increasing ice-free periods in the Arctic creates greater opportunities for offshore oil and gas development in the Chukchi Sea, Alaska. These activities, and their reliance on onshore infrastructure and shipping, require information on the distribution of Pacific walrus and their habitats to identify ways for industry to operate effectively while meeting conservation goals set by government agencies. USGS scientists developed novel satellite radio tracking devices to map feeding areas used by walruses. These maps are used by the U.S. Navy and the U.S. Coast Guard for managing vessel transit corridors. Scientists are now developing ways to use unmanned aircraft systems to estimate the abundance and distribution of Pacific walruses and their habitats in the Chukchi Sea. These studies have informed incidental take regulations and mitigation measures that can guide offshore development in minimizing interactions with walrus foraging and resting areas.

\section{Contact}

Grant V. Hilderbrand, USGS Alaska Science Center, ghilderbrand@usgs.gov, (907) 786-7076

\section{Publications}

Battaile, B.C., Jay, C.V., Udevitz, M.S., and Fischbach, A.S., 2017, Evaluation of a method using survey counts and tag data to estimate the number of Pacific walruses ( 0 dobenus rosmarus divergens) using a coastal haulout in northwestern Alaska: Polar Biology, v. 40, no. 7, p. 1359-1369, https://doi.org/10.1007/s00300-016-2060-5.

Beatty, W.S., Jay, C.V., Fischbach, A.S., Grebmeier, J.M., Taylor, R.L., Blanchard, A.L., and Jewett, S.C., 2016, Space use of a dominant Arctic vertebrate-Effects of prey, sea ice, and land on Pacific walrus resource selection: Biological Conservation, v. 203, p. 25-32, https://doi.org/10.1016/j.biocon.2016.08.035.

Fischbach, A., and Jay, C.V., 2016, A strategy for recovering continuous behavioral telemetry data from Pacific walruses: Wildlife Society Bulletin, v. 40, no. 3, p. 599-604, https://doi.org/10.1002/wsb.685.

Fischbach, A.S., Kochnev, A.A., Garlich-Miller, J.L., and Jay, C.V., 2016, Pacific walrus coastal haulout database, 1852-2016Background report: U.S. Geological Survey Open-File Report 2016-1108, 27 p., https://doi.org/10.3133/ofr20161108.

Udevitz, M.S., Jay, C.V., Taylor, R.L., Fischbach, A.S., Beatty, W.S., and Noren, S.R., 2017, Forecasting consequences of changing sea ice availability for Pacific walruses: Ecosphere, v. 8, no. 11, e02014, 30 p., https://doi.org/10.1002/ecs2.2014. 


\section{Atlantic Ocean and Gulf of Mexico}

\section{Florida Manatee Movement and Habitat Use in the Northern Gulf of Mexico}

The USGS is collecting data related to Florida manatee distribution and their use of habitat and travel corridors in the northern GOM (Florida, Alabama, Mississippi, Louisiana, and Texas). Manatees known to travel to the northern GOM are being captured for health assessments and are tracked with GPS telemetry to acquire fine-scale habitat use and movement information. Field studies focus on characterization of local resources in areas with appropriate habitat or consistent manatee use. The data collected are being used by BOEM to inform the risk of interactions between manatees and vessels traveling through coastal areas to and from offshore oil and gas structures.

\section{Contacts}

Daniel Slone, USGS Wetland and Aquatic Research Center, dslone@usgs.gov, (352) 264-3551

Jim Reid, USGS Wetland and Aquatic Research Center; jreid@usgs.gov; (352) 264-3546

Susan Butler, USGS Wetland and Aquatic Research Center; sbutler@usgs.gov; (352) 264-3557

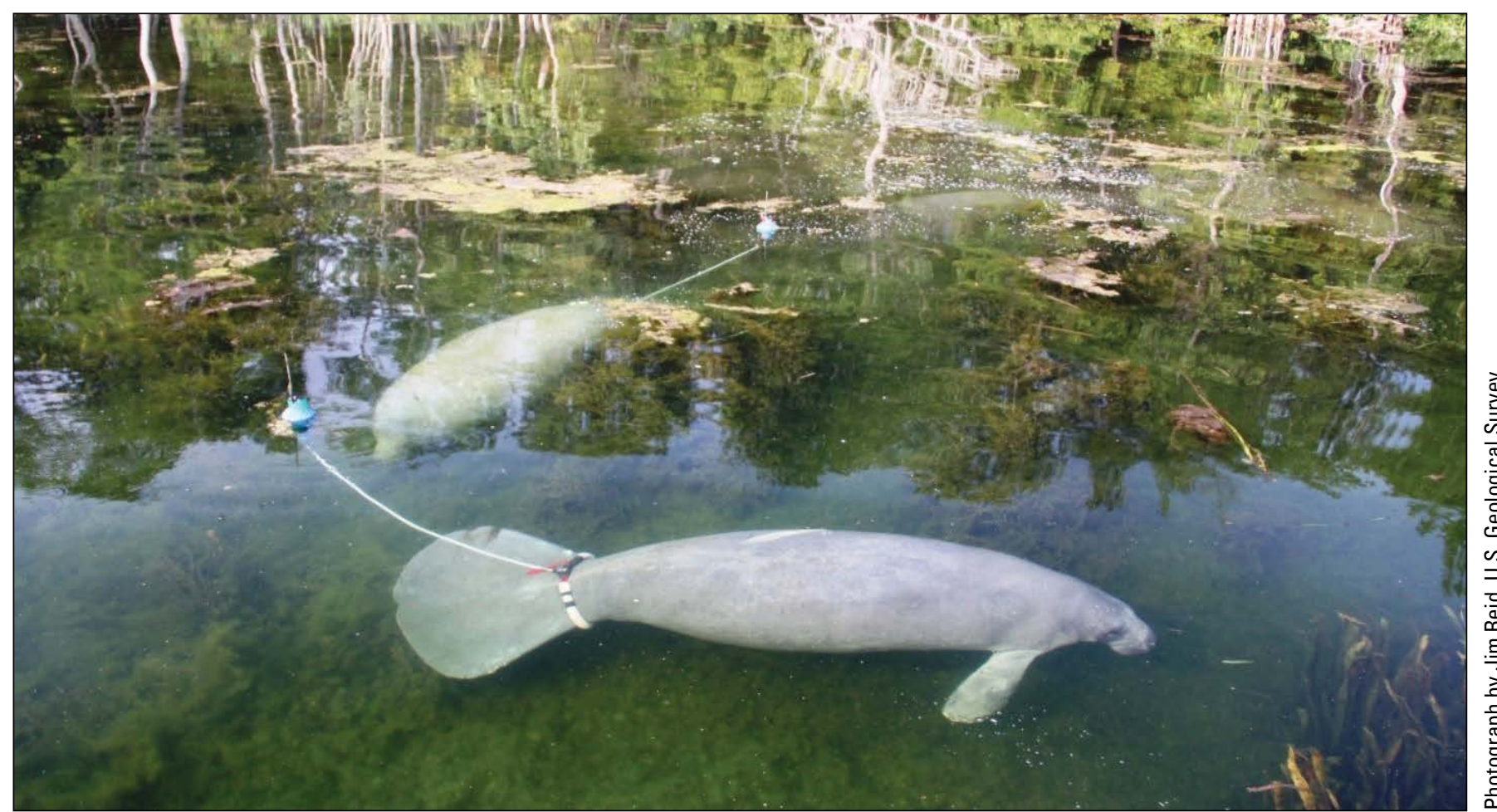

Radio-tagged Florida manatees in the Wakulla River, Florida.

\section{Publications}

Haase, C.G., Fletcher, R.J., Jr., Slone, D.H., Reid, J.P., and Butler, S.M., 2017, Landscape complementation revealed through bipartite networks-An example with the Florida manatee: Landscape Ecology, v. 32, no. 10, p. 1999-2014, https://doi.org/10.1007/s10980-017-0560-5.

Littles, C.J., Bonde, R.K., Butler, S.M., Jacoby, C.A., Notestein, S.K., Reid, J.P., Slone, D.H., and Frazer, T.K., 2019, Coastal habitat change and marine megafauna behavior-Florida manatees encountering reduced food provisions in a prominent winter refuge: Endangered Species Research, v. 38, p. 29-43, https://doi.org/10.3354/esr00933.

Slone, D.H., Butler, S.M., and Reid, J.P., 2018, Movements and habitat use locations of manatees within Kings Bay Florida during the Crystal River National Wildlife Refuge winter season (November 15-March 31): U.S. Geological Survey OpenFile Report 2018-1051, 11 p., https://doi.org/10.3133/ofr20181051.

Slone, D.H., Butler, S.M., Reid, J.P., and Haase, C.G., 2017, Timing of warm water refuge use in Crystal River National Wildlife Refuge by manatees_-Results and insights from Global Positioning System telemetry data: U.S. Geological Survey Open-File Report 2017-1146, 17 p., https://doi.org/10.3133/ofr20171146. 


\section{Science to Support the Transition of Florida Manatees to Natural Warm-Water Sites}

In winter, a large segment of the Florida manatee population depends on effluents of heated water produced by coastal thermoelectric power plants. Steam-based electricity generation requires large quantities of water for cooling. The power industry in Florida is transitioning to new technologies that reduce warm-water effluents and working with the USFWS and the Florida Fish and Wildlife Conservation Commission as the agencies develop and implement a manatee warm-water action plan. USGS scientists are developing models based on long-term photographic identification, telemetry, and USGS water studies to predict present and future use of warm-water sites. They are also working with the USFWS to develop decision support tools to identify and evaluate management scenarios and address changing conditions within the network of natural and artificial warmwater sites.

\section{Contacts}

Catherine Langtimm, USGS Wetland and Aquatic Research Center, clangtimm@usgs.gov, (352) 264-3489

Daniel Slone, USGS Wetland and Aquatic Research Center, dslone@usgs.gov, (352) 264-3551

\section{Publication}

Runge, M.C., Sanders-Reed, C.A., Langtimm, C.A., Hostetler, J.A., Martin, J., Deutsch, C.J., Ward-Geiger, L.I., and Mahon, G.L., 2017, Status and threats analysis for the Florida manatee (Trichechus manatus latirostris), 2016: U.S. Geological Survey Scientific Investigations Report 2017-5030, 40 p., https://doi.org/10.3133/sir20175030.

\section{Gulf of Mexico Marine Assessment Program for Protected Species}

The Gulf of Mexico Marine Assessment Program for Protected Species, or GoMMAPPS (https://www.boem.gov/ gommapps/), is a multiagency partnership between BOEM, the USFWS, NOAA, the National Oceanographic Partnership Program (NOPP), and the USGS with the goal of conducting broad-scale surveys of protected species to inform managers on the distribution and abundance of marine animals across seasons and years. The USGS is leading efforts to provide information to GoMMAPPS on abundance, distribution, and movement patterns of sea turtles and seabirds. Some of the largest gaps in knowledge of marine turtle and seabird ecology occur in areas of heavy oil and gas use, including BOEM's GOM Central and Western Planning Areas. Information generated by the USGS and its GoMMAPPS partners can be used in support of various BOEM/ Bureau of Safety and Environmental Enforcement (BSEE) activities, including oil spill risk analysis, decommissioning of oil platforms, and movements of vessels.

\section{Contacts}

Kristen M. Hart (for sea turtles), USGS Wetland and Aquatic Research Center, kristen_hart@usgs.gov, (954) 377-5922 Margaret M. Lamont, USGS Wetland and Aquatic Research Center, mlamont@usgs.gov, (352) 264-3526 Patrick Jodice (for seabirds), USGS South Carolina Cooperative Fish and Wildlife Research Unit, pjodice@clemson.edu, (864) 656-6190

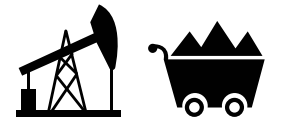

\section{Sea Turtle Movement and Habitat Use in the Northern Gulf of Mexico}

The USFWS and NOAA's National Marine Fisheries Service (NMFS) identified that information on the distribution, seasonal movements, vital rates, and habitat use for all life stages of marine turtles is needed to recover these threatened and endangered species. USGS scientists are attaching satellite tags and acceleration data loggers capable of logging dive data to provide fine-scale information on the dive profiles of Kemp's ridleys, loggerheads, and green sea turtles in the GOM. These dive profiles provide insight into turtle depth use, movement patterns, mortality risk, use of post-dredge sites, use of preferred thermal zones, and time spent near the vicinity of dredging activities. This study can directly address recovery and protection goals and provide information on in-water aggregations of sub-adult, juvenile, and adult marine turtles in the GOM.

\section{Contacts}

Kristen M. Hart, USGS Wetland and Aquatic Research Center, kristen_hart@usgs.gov, (954) 377-5922 Margaret M. Lamont, USGS Wetland and Aquatic Research Center, mlamont@usgs.gov, (352) 209-4306 


\section{Deep-Sea Exploration to Inform Potential Offshore Energy and Minerals Development}

The OCS contains extensive and valuable commercial and recreational fisheries, as well as unique deep-sea communities, including corals and chemosynthetic seeps. BOEM, the USGS, and NOAA's Office of Exploration and Research (OER) are partners on the Deep-Sea Exploration to Advance Research on Coral/Canyon/Cold Seep Habitats (DEEP SEARCH) study, which is part of the NOPP. DEEP SEARCH aims to further the understanding of the distribution of sensitive deep-sea habitats in the U.S. Atlantic region. USGS scientists worked with BOEM managers to develop a multidisciplinary research program that focuses on ecosystem-based studies in areas considered for oil and gas leasing and (or) renewable energy development. The information generated from this project can allow managers to design and support an adaptive, ecosystem-based approach to DOI's stewardship responsibilities while allowing for development of offshore energy resources.

\section{Contact}

Amanda Demopoulos, USGS Wetland and Aquatic Research Center, ademopoulos@usgs.gov, (352) 264-3490

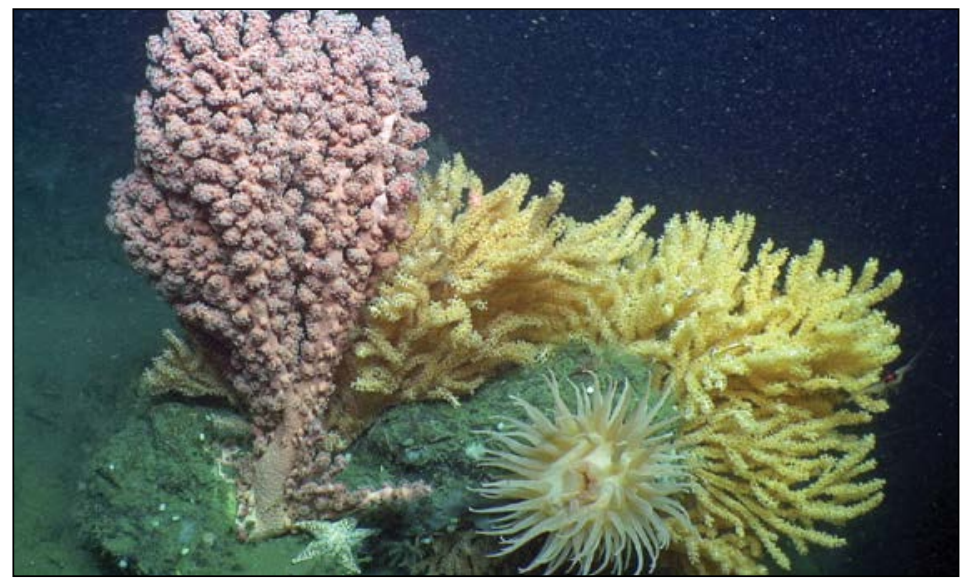

Red bubbleaum coral at a depth of 440 meters in Norfolk Canvon.

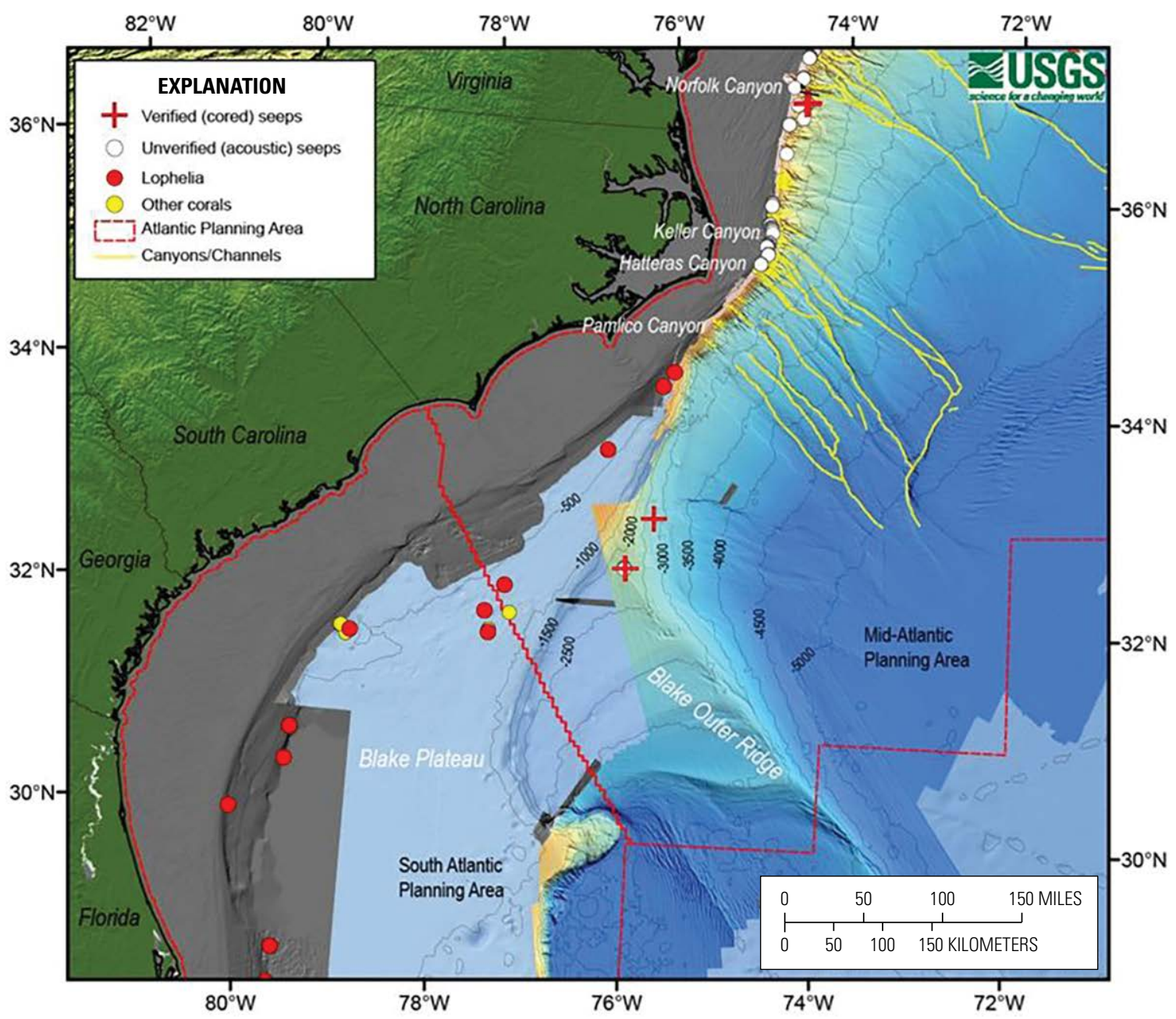

Target areas surveyed during the Deepwater Atlantic Habitats II study. Image from U.S. Geological Survey. 


\section{Publications}

Bourque, J.R., Robertson, C.M., Brooke, S., and Demopoulos, A.W.J., 2017, Macrofaunal communities associated with chemosynthetic habitats from the US Atlantic margin-A comparison among depth and habitat types: Deep Sea Research Part II-Topical Studies in Oceanography, v. 137, p. 42-55, https://doi.org/10.1016/j.dsr2.2016.04.012.

Chaytor, J.D., Demopoulos, A.W.J., ten Brink, U.S., Baxter, C., Quattrini, A.M., and Brothers, D.S., 2016, Assessment of canyon wall failure process from multibeam bathymetry and remotely operated vehicle (ROV) observations, U.S. Atlantic Continental Margin, chap. in Lamarche, G., Mountjoy, J., Bull, S., Hubble, T., Krastel, S., Lane, E., Micallef, A., Moscardelli, L., Mueller, C., Pecher, I., and Woelz, S., eds., Submarine mass movements and their consequences (7th International Symposium): Basel, Switzerland, Springer International, p. 103-113, https://doi.org/10.1007/978-3-319-20979-1_10.

Coykendall, D.K., Cornman, R.S., Prouty, N.G., Brooke, S., Demopoulos, A.W.J., and Morrison, C.L., 2019, Molecular characterization of Bathymodiolus mussels and gill symbionts associated with chemosynthetic habitats from the U.S. Atlantic margin: PLOS ONE, v. 14, no. 3, e0211616, 28 p., https://doi.org/10.1371/journal.pone.0211616.

Coykendall, D.K., Nizinski, M.S., and Morrison, C.L., 2017, A phylogenetic perspective on diversity of Galatheoidea (M unida, M unidopsis) from cold-water coral and cold seep communities in the western North Atlantic Ocean: Deep Sea Research IITopical Studies in Oceanography, v. 137, p. 258-272, https://doi.org/10.1016/j.dsr2.2016.08.014.

Demopoulos, A.W.J., McClain-Counts, J., Ross, S.W., Brooke, S., and Mienis, F., 2017, Food-web dynamics and isotopic niches in deep-sea communities residing in a submarine canyon and on the adjacent open slopes: Marine Ecology Progress Series, v. 578, p. 19-33, https://doi.org/10.3354/meps12231.

Demopoulos, A.W.J., McClain-Counts, J.P., Bourque, J.R., Prouty, N.G., Smith, B.J., Brooke, S., Ross, S.W., and Ruppel, C.D., 2019, Examination of Bathymodiolus childressi nutritional sources, isotopic niches, and food-web linkages at two seeps in the US Atlantic margin using stable isotope analysis and mixing models: Deep Sea Research Part I-Oceanographic Research Papers: v. 148, p. 53-66, https://doi.org/10.1016/j.dsr.2019.04.002.

Kellogg, C.A., Goldsmith, D.B., and Gray, M.A., 2017, Biogeographic comparison of Lophelia-associated bacterial communities in the western Atlantic reveals conserved core microbiome: Frontiers in Microbiology, v. 8, 15 p., https://doi.org/10.3389/fmicb.2017.00796.

Prouty, N.G., Sahy, D., Ruppel, C.D., Roark, E.B., Condon, D., Brooke, S., Ross, S.W., and Demopoulos, A.W.J., 2016, Insights into methane dynamics from analysis of authigenic carbonates and chemosynthetic mussels at newly-discovered Atlantic Margin seeps: Earth and Planetary Science Letters, v. 449, p. 332-344, https://doi.org/10.1016/j.eps1.2016.05.023.

Quattrini, A.M., Nizinski, M.S., Chaytor, J.D., Demopoulos, A.W.J., Roark, E.B., France, S.C., Moore, J.A., Heyl, T., Auster, P.J., Kinlan, B., Ruppel, C., Elliott, K.P., Kennedy, B.R.C., Lobecker, E., Skarke, A., and Shank, T.M., 2015, Exploration of the canyon-incised continental margin of the Northeastern United States reveals dynamic habitats and diverse communities: PLOS ONE, v. 10, no. 10, e0139904, 32 p., https://doi.org/10.1371/journal.pone.0139904.

\section{Changes to Infaunal Communities Associated With Deep-Sea Coral and Their Potential Recovery From the Deepwater Horizon Oil Spill}

The Deepwater Horizon (DWH) oil spill effected changes in multiple ecosystems within the GOM, including coastal and deep-sea ecosystems that support large and valuable commercial and recreational fisheries and numerous threatened or endangered species. A few studies have documented the acute impacts of the spill to deep-sea communities, but long-term changes and recovery of communities have not been assessed. The USGS is leading an unprecedented 7-year post-spill assessment of the GOM-OCS deep-sea coral communities that tracks change in coral-associated sediment communities. These results can help inform future deep-sea ecosystem monitoring and restoration activities and can lead to the development of effective adaptive management and conservation strategies for these vulnerable ecosystems.

\section{Contact}

Amanda Demopoulos, USGS Wetland and Aquatic Research Center, ademopoulos@usgs.gov, (352) 264-3490

\section{Publications}

Bourque, J.R., and Demopoulos, A.W.J., 2018, The influence of different deep-sea coral habitats on sediment macrofaunal community structure and function: PeerJ, v. 6, e5276, 32 p., https://doi.org/10.7717/peerj.5276. 
Demopoulos, A.W.J., Bourque, J.R., Cordes, E., and Stamler, K.M., 2016, Impacts of the Deepwater Horizon oil spill on deep-sea coral-associated sediment communities: Marine Ecology Progress Series, v. 561, p. 51-68, https://doi.org/10.3354/ meps 11905 .

Demopoulos, A.W.J., Bourque, J.R., Durkin, A., and Cordes, E.E., 2018, The influence of seep habitats on sediment macrofaunal biodiversity and functional traits: Deep Sea Research Part I-Oceanographic Research Papers, v. 142, p. 77-93, https://doi.org/10.1016/j.dsr.2018.10.004.

Prouty, N.G., Campbell, P.L., Mienis, F., Duineveld, G., Demopoulos, A.W.J., Ross, S.W., and Brooke, S., 2016, Impact of Deepwater Horizon spill on food supply to deep-sea benthos communities: Estuarine, Coastal and Shelf Science, v. 169, p. 248-264, https://doi.org/10.1016/j.ecss.2015.11.008.

\section{Pacific 0cean}

\section{Benthic Assemblages of Mega Epifauna on the Oregon Continental Margin}

The USGS partnered with BOEM to map an area of the Oregon OCS under consideration for development of a floating wind energy farm. BOEM requires seafloor mapping and site characterization studies to evaluate the impact of seafloor and subseafloor conditions on the installation, operation, and structural integrity of proposed renewable energy projects, as well as to assess the potential effects of construction and operations on benthic ecosystems and archaeological resources. Analysis of video data collected to determine correlations between substrate, depth, and invertebrate assemblages resulted in the identification of seven biomes: three hard-bottom biomes and four soft-bottom biomes. The geologic, topographic, and hydrologic information provided by the USGS support BOEM's mission of responsible management of the Nation's natural resources.

\section{Contact}

Guy R. Cochrane, USGS Pacific Coastal and Marine Science Center, gcochrane@usgs.gov, (831) 460-7554

\section{Publications}

Cochrane, G.R., 2017, Interpretive data release for Oregon OCS seafloor mapping-Selected lease blocks relevant to renewable energy: U.S. Geological Survey data release, https://doi.org/10.5066/F7000069.

Cochrane, G.R., Hemery, L.G., and Henkel, S.K., 2017, Oregon OCS seafloor mapping-Selected lease blocks relevant to renewable energy: U.S. Geological Survey Open-File Report 2017-1045 and Bureau of Ocean Energy Management OCS Study BOEM 2017-018, 51 p., https://doi.org/10.3133/ofr20171045.

Hemery, L.G., Henkel, S.K., and Cochrane, G.R., 2018, Benthic assemblages of mega epifauna on the Oregon continental margin: Continental Shelf Research, v. 159, p. 24-32, https://doi.org/10.1016/j.csr.2018.03.004.

\section{Predicting the Effects of Wave Energy Facilities on Nearshore Ecosystems}

The USGS is investigating the possible effects of wave energy conversion (WEC) devices on nearshore ecosystems, such as kelp forests. WEC devices pull potential energy from the rise and fall or surge of open ocean swells and convert it into energy for human use. WEC devices can affect the local environment through noise, hazard, construction, anchoring, animal entanglement, turbulence, sedimentation, fouling, and reduction in wave height. Results from these studies can help BOEM determine the degree to which WECs affect currents and other physical features of the marine environment and predict the ecological consequences of various siting options for proposed marine renewable energy facilities. These studies are being conducted in anticipation of an increase in the coming years of applications to BOEM for development of WEC devices on the Pacific OCS.

\section{Contact}

Kevin Lafferty, USGS Western Ecological Research Center, klafferty@usgs.gov, (805) 893-8778 


\section{Fish and Other Aquatic Species and Hydropower}

Hydropower has served as a significant and reliable source of electricity in the United States for more than five decades. One of the main challenges in managing rivers with hydropower resources is maintaining or restoring commercially, recreationally, and culturally important species such as salmon and herring. USGS scientists are applying extensive interdisciplinary capabilities in fish biology, ecology, hydrology, and engineering to improve fish passage designs and ultimately help restore fisheries in managed rivers. USGS scientists are also providing tools for early detection and prevention of invasive species, such as zebra and quagga mussels, which foul hydroelectric facilities and threaten aquatic ecosystems.

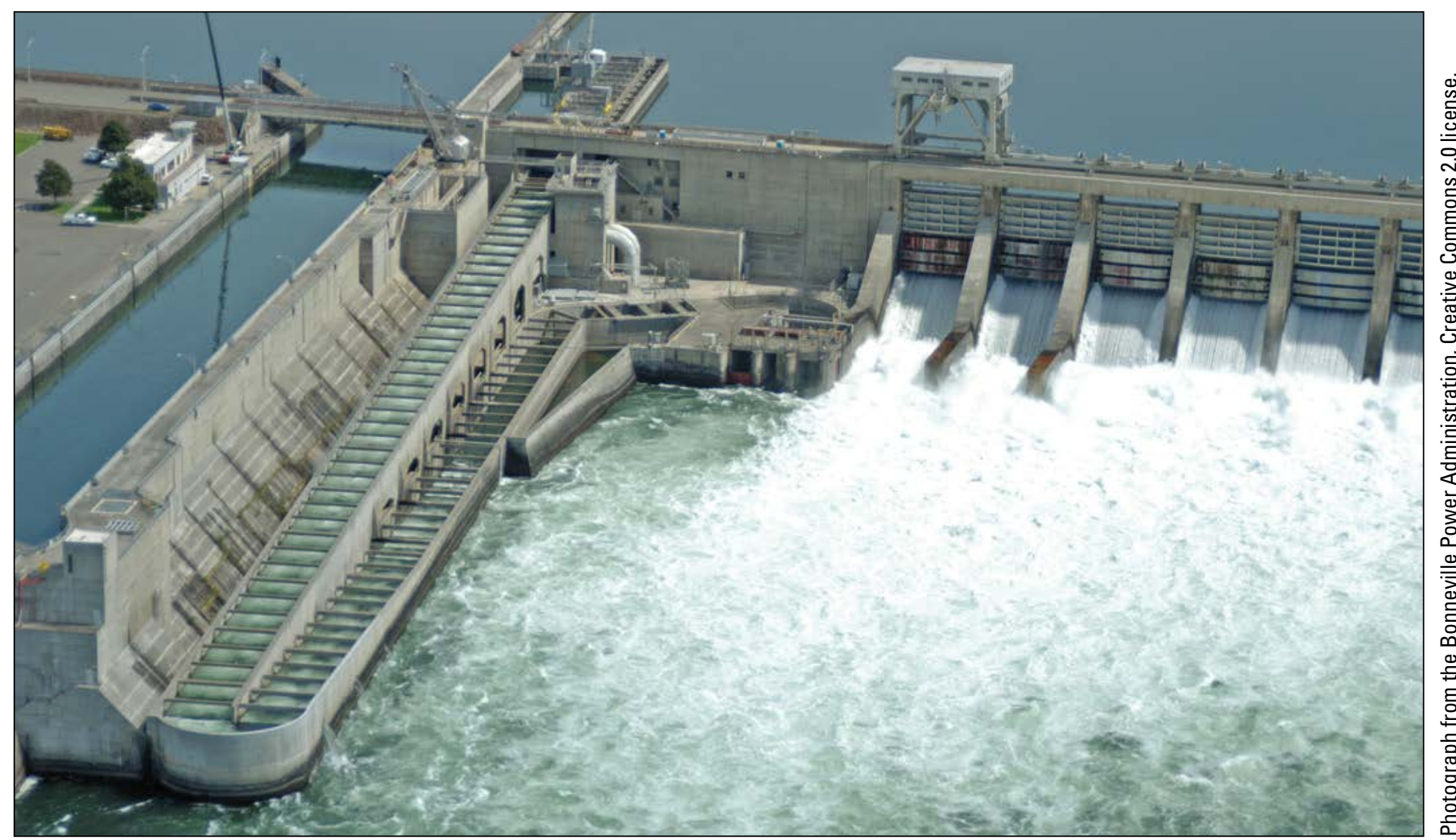

Fish ladder at McNary Dam on the Columbia River, Washington and Oregon.

\section{Fish Passage and Behavior at Hydropower Dams}

\section{Full-Scale Development and Evaluations of Fish Passage Structures and Fish Behavior}

Many migratory fish species have been in decline due in large part to dams and poorly designed fishways that prevent fish from reaching spawning and feeding grounds. The USGS has a unique large-scale flume facility that allows for full-scale testing of upstream and downstream passage conditions with live fish species. The S.O. Conte Anadromous Fish Research Center laboratory provides semicontrolled conditions that enable the USGS, NMFS, DOE, and State scientists and engineers to improve and develop new fish passage designs and technologies and also identify behaviors and hydraulics that inform design criteria for successful fish passage. In collaboration with the University of Massachusetts, USGS scientists are testing new fishway attraction and entrance technology designed to enhance fish passage with broad applicability to many target species, including Atlantic salmon, American shad, alewife, and blueback herring. The goal of this work is to restore self-sustaining populations of migratory fish while maintaining a balance between energy production, water management, and ecosystem restoration.

\section{Contacts}

Theodore R. Castro-Santos, USGS Leetown Science Center, tcastrosantos@usgs.gov, (413) 863-3838

Alex Haro, USGS Leetown Science Center, aharo@usgs.gov, (413) 863-3806

Kevin B. Mulligan, USGS Leetown Science Center, kmulligan@usgs.gov, (413) 863-3837 


\section{Publications}

Baker, N., Haro, A., Watten, B., Noreika, J., and Bolland, J.D., 2019, Comparison of attraction, entrance and passage of downstream migrant American eels (Anguilla rostrata) through airlift and siphon deep entrance bypass systems: Ecological Engineering, v. 126, p. 74-82, https://doi.org/10.1016/j.ecoleng.2018.10.011.

Bayse, S.M., McCormick, S.D., and Castro-Santos, T., 2019, How lipid content and temperature affect American shad (Alosa sapidissima) attempt rate and sprint swimming - Implications for overcoming migration barriers: Canadian Journal of Fisheries and Aquatic Sciences, e-First article posted March 26, 2019, 43 p., https://doi.org/10.1139/cjfas-2018-0406.

Haro, A., Watten, B., and Noreika, J., 2016, Passage of downstream migrant American eels through an airlift-assisted deep bypass: Ecological Engineering, v. 91, v. 545-552, https://doi.org/10.1016/j.ecoleng.2016.02.028.

Haro, A.J., Mulligan, K., Suro, T.P., Noreika, J., and McHugh, A., 2017, Hydraulic and biological analysis of the passability of select fish species at the U.S. Geological Survey streamgaging weir at Blackwells Mills, New Jersey: U.S. Geological Survey Scientific Investigations Report 2017-5103, 15 p., https://doi.org/10.3133/sir20175103.

Miehls, S.M., Johnson, N.S., and Haro, A., 2017, Electrical guidance efficiency of downstream migrating juvenile sea lamprey decreases with increasing water velocity: Transactions of the American Fisheries Society, v. 146, no. 2, p. 299-307, https://doi.org/10.1080/00028487.2016.1256834.

Mulligan, K.B., Towler, B., Haro, A., and Ahlfeld, D.P., 2017, A computational fluid dynamics modeling study of guide walls for downstream fish passage: Ecological Engineering, v. 99, p. 324-332, https://doi.org/10.1016/j.ecoleng.2016.11.025.

Mulligan, K.B., Towler, B., Haro, A., and Ahlfeld, D.P., 2017, Sensitivity of the downward to sweeping velocity ratio to the bypass flow percentage along a guide wall for downstream fish passage: Ecological Engineering, v. 109, pt. A, p. 10-14, https://doi.org/10.1016/j.ecoleng.2017.08.012.

Mulligan, K.B., Towler, B., Haro, A., and Ahlfeld, D.P., 2018, Downstream fish passage guide walls—A hydraulic scale model analysis: Ecological Engineering, v. 115, p. 122-138, https://doi.org/10.1016/j.ecoleng.2018.02.006.

Silva, A.T., Lucas, M.C., Castro-Santos, T., Katopodis, C., Baumgartner, L.J., Thiem, J.D., Aarestrup, K., Pompeu, P.S., O’Brien, G.C., Braun, D.C., Burnett, N.J., Zhu, D.Z., Fjeldstad, H.-P., Forseth, T., Rajaratnam, N., Williams, J.G., and Cooke, S.J., 2018, The future of fish passage science, engineering, and practice: Fish and Fisheries, v. 19, no. 2, p. 340-362, https://doi.org/10.1111/faf.12258.

\section{75. Biotelemetry Studies of Fish Behavior and Passage Through Dams}

Understanding and quantifying fish behavior is essential for identifying fish passage problems and developing effective passage solutions across hydropower dams and other manmade barriers. Biotelemetry, or using radio and acoustic telemetry to track biological organisms, has emerged as the method of choice for acquiring detailed, individual-based data to quantify passage and critical fish behaviors. Working in collaboration with the USFWS, NMFS, DOE, and State agencies, the USGS S.O. Conte Anadromous Fish Research Center scientists have adapted and developed advanced telemetry technologies for fish passage studies and statistical analysis methods for fish passage evaluations. These advances can help maximize the return on labor- and cost-intensive studies that integrate fish behavior with hydraulic and physical characteristics of passage structures to improve passage design.

\section{Contact}

Theodore R. Castro-Santos, USGS Leetown Science Center, tcastrosantos@usgs.gov, (413) 863-3838

\section{Publications}

Harbicht, A.B., Castro-Santos, T., Ardren, W.R., Gorsky, D., and Fraser, D.J., 2017, Novel, continuous monitoring of fine-scale movement using fixed-position radiotelemetry arrays and random forest location fingerprinting: Methods in Ecology and Evolution, v. 8, no. 7, p. 850-859, https://doi.org/10.1111/2041-210X.12745.

Nyqvist, D., Greenberg, L.A., Goerig, E., Calles, O., Bergman, E., Ardren, W.R., and Castro-Santos, T., 2017, Migratory delay leads to reduced passage success of Atlantic salmon smolts at a hydroelectric dam: Ecology of Freshwater Fish, v. 26, p. 707-718, https://doi.org/10.1111/eff.12318.

Theim, J.D., Dawson, J.W., Gleiss, A.C., Martins, E.G., Haro, A., Castro-Santos, T., Danylchuk, A.J., Wilson, R.P., and Cooke, S.J., 2015, Accelerometer-derived activity correlates with volitional swimming speed in lake sturgeon (Acipenser fulvescens): Canadian Journal of Zoology, v. 93, no. 8, p. 645-654, https://doi.org/10.1139/cjz-2014-0271. 


\section{Downstream Fish Passage and Survival Through Dams}

Dams can negatively affect emigrating juvenile salmon populations because fish must pass through the impounded river created by the dam, negotiate a passage route at the dam, and emigrate through a riverine reach that has been affected by altered river discharge. Threatened populations of Chinook salmon and steelhead are a primary focus for regional resource managers in the Pacific Northwest. USGS scientists monitor the movements of radio-tagged juvenile salmonids released upstream from hydroelectric dams to study how fish move across reservoirs and passage structures to better understand how these structures and water discharge methods affect fish passage success and survival. Results from these studies can inform hydropower dam operators and resource managers on ways to improve route-specific salmon passage and survival.

\section{Contact}

Tobias J. Kock, USGS Western Fisheries Research Center, tkock@usgs.gov, (509) 538-2915

\section{Publications}

Courter, I.I., Garrison, T.M., Kock, T.J., Perry, R.W., Child, D.B., and Hubble, J.D., 2016, Benefits of prescribed flows for salmon smolt survival enhancement vary longitudinally in a highly managed river system: River Research and Applications, v. 32, no. 10, p. 1999-2008, https://doi.org/10.1002/rra.3066.

Hansen, A.C., Kock, T.J., and Hansen, G.S., 2017, Synthesis of downstream fish passage information at projects owned by the U.S. Army Corps of Engineers in the Willamette River Basin, Oregon: U.S. Geological Survey Open-File Report 2017 1101,118 p., https://doi.org/10.3133/ofr20171101.

Kock, T.J., Evans, S.D., Hansen, A.C., Perry, R.W., Hansel, H.C., Haner, P.V., and Tomka, R.G., 2018, Evaluation of sockeye salmon after passage through an innovative upstream fish-passage system at Cle Elum Dam, Washington, 2017: U.S. Geological Survey Open-File Report 2018-1116, 30 p., https://doi.org/10.3133/ofr20181116.

Kock, T.J., Perry, R.W., and Hansen, A.C., 2016, Survival of juvenile Chinook salmon and coho salmon in the Roza Dam fish bypass and in downstream reaches of the Yakima River, Washington, 2016 (ver. 1.1, April 2017): U.S. Geological Survey Open-File Report 2016-1210, 32 p., https://doi.org/10.3133/ofr20161210.

Kock, T.J., Verretto, N.E., Ackerman, N.K., Perry, R.W., Beeman, J.W., Garello, M.C., and Fielding, S.D., 2019, Assessment of operational and structural factors influencing performance of fish collectors in forebays of high-head dams: Transactions of the American Fisheries Society, v. 148, no. 2, p. 464-479, https://doi.org/10.1002/tafs.10146.

Liedtke, T.L., Kock, T.J., and Hurst, W., 2018, Passage survival of juvenile steelhead, coho salmon, and Chinook salmon in Lake Scanewa and at Cowlitz Falls Dam, Cowlitz River, Washington, 2010-16: U.S. Geological Survey Open-File Report 2018-1050, 44 p., https://doi.org/10.3133/ofr20181050.

Liedtke, T.L., Lampman, R.T., Deng, D.Z., Beals, T.E., Porter, M.S., Hansen, A.C., Kock, T.J., Tomka, R.G., and Monk, P., 2019, Movements of juvenile Pacific lamprey (E ntosphenus tridentatus) in the Yakima and Columbia Rivers, Washington, 2018-A pilot study using acoustic telemetry: U.S. Geological Survey Open-File Report 2019-1058, 29 p., https://doi.org/10.3133/ofr20191058.

Perry, R.W., Kock, T.J., Courter, I.I., Garrison, T.M., Hubble, J.D., and Child, D.B., 2016, Dam operations affect route-specific passage and survival of juvenile Chinook salmon at a main-stem diversion dam: River Research and Applications, v. 32, no. 10, p. 2009-2019, https://doi.org/10.1002/rra.3059.

Romine, J.G., Perry, R.W., Pope, A.C., Stumpner P., Liedtke, T.L., Kumagai, K.K., and Reeves, R.L., 2016, Evaluation of a floating fish guidance structure at a hydrodynamically complex river junction in the Sacramento-San Joaquin River Delta, California, U.S.A.: Marine and Freshwater Research, v. 68, no. 5, p. 878-888, https://doi.org/10.1071/MF15285.

\section{Behavior of Fish Routed Around a Hydroelectric Dam}

USGS scientists are using acoustic cameras to assess the behavior and abundance of bull trout-size fish at the entrance to Oregon's North Fork Reservoir juvenile fish floating surface collector (FSC) to better understand factors that influence fish passage at hydropower dams. The purpose of the FSC is to collect downriver migrating juvenile salmonids and safely route them around the hydroelectric dam. The acoustic cameras also determine if the presence of bull trout-size fish influence the collection or abundance of juvenile salmonids near the FSC. Results from these studies can be used by managers to help inform decisions about collection and passage solutions for juvenile salmonids at the FSC, as well as to identify the potential for predation by bull trout near the FSC entrance.

\section{Contact}

Noah Adams, USGS Western Fisheries Research Center, nadams@usgs.gov, (509) 538-2964 


\section{Publications}

Adams, N.S., and Smith, C.D., 2017, Spatial and temporal distribution of bull trout (Salvelinus confluentus)-size fish near the floating surface collector in the North Fork Reservoir, Oregon, 2016: U.S. Geological Survey Open-File Report 2017-1080, 27 p., https://doi.org/10.3133/ofr20171080.

Smith, C.D., Plumb J.M., and Adams, N.S., 2018, Fish behavior and abundance monitoring near a floating surface collector in North Fork Reservoir, Clackamas River, Oregon, using multi-beam acoustic imaging sonar: U.S. Geological Survey OpenFile Report 2018-1182, 28 p., https://doi.org/10.3133/ofr20181182.

\section{级}

\section{Developing Selective Fish Passage to Block Invasive Sea Lamprey}

The sea lamprey is an invasive, parasitic fish species in the Great Lakes, causing damage to recreational and commercial fisheries, which are valued at more than $\$ 7$ billion annually (Great Lakes Fishery Commission, 2018). USGS scientists, in collaboration with the Great Lakes Fishery Commission, University of Massachusetts, Michigan State University, and the University of Guelph in Ontario, Canada, are evaluating velocity-based barriers, nonstick surfaces, and other strategies that take advantage of the relatively poor swimming abilities of lamprey. The goal is to develop selective fish passage that would block the passage of sea lamprey while allowing desirable fish species to move through fish passage structures unharmed.

\section{Contact}

Theodore R. Castro-Santos, USGS Leetown Science Center, tcastrosantos@usgs.gov, (413) 863-3838

\section{Publications}

Castro-Santos, T., Shi, X., and Haro, A., 2017, Migratory behavior of adult sea lamprey and cumulative passage performance through four fishways: Canadian Journal of Fisheries and Aquatic Sciences, v. 74, no. 5, p. 790-800, https://doi.org/10.1139/cjfas-2016-0089.

Rous, A.M., McLean, A.R., Barber, J., Bravener, G., Castro-Santos, T., Holbrook, C.M., Imre, I., Pratt, T.C., and McLaughlin, R.L., 2017, Spatial mismatch between sea lamprey behaviour and trap location explains low success at trapping for control: Canadian Journal of Fisheries and Aquatic Sciences, v. 74, no. 12, p. 2085-2097, https://doi.org/10.1139/cjfas-2016-0445.

\section{Hydropower Effects on Fish and Aquatic Resources}

\section{IU 79. Evaluating Flow Management as a Strategy to Recover Endangered Pallid Sturgeon in the Upper Missouri River}

Habitat fragmentation has been identified as a primary factor in the decline of large river fish species, especially sturgeon that rely on access to free-flowing rivers for spawning and early development. On the upper Missouri River, Fort Peck and Garrison Dams limit the length of free-flowing river available to the endangered pallid sturgeon. These barriers restrict the upstream migration of adults and downstream larval dispersal. USGS scientists evaluated various flow-management scenarios that might aid species recovery. Given the current thermal regime and understanding of pallid sturgeon development, results indicate that the time required for pallid sturgeon embryos to transition to the benthos and initiate feeding might exceed the duration of drift available to them given constraints of reservoir operations. Perturbations to the thermal regime thus influence drift dynamics and may provide options to increase developmental rate, which would, in turn, decrease the length of river required for the dispersal phase of the pallid sturgeon life cycle.

\section{Contact}

Susannah Erwin, USGS Columbia Environmental Research Center, serwin@usgs.gov, (573) 441-2978

\section{Publication}

Erwin, S.O., Bulliner, E.A., Fischenich, J.C., Jacobson, R.B., Braaten, P.J., and DeLonay, A.J., 2018, Evaluating flow management as a strategy to recover an endangered sturgeon species in the Upper Missouri River, USA: River Research and Applications, v. 34, no. 10, p. 1254-1266, https://doi.org/10.1002/rra.3371. 


\section{1/ 80. Hydropower Effects on River Food Webs}

Aquatic insects are a cornerstone of river food webs. USGS scientists demonstrated that flow regimes on the Colorado River favoring hydroelectric-power generation can eliminate many aquatic insect species from downstream habitats. This research informed experimental flow releases from Glen Canyon Dam that were conducted from May to August 2018 and again from May to August 2019. The experiment involves releasing stable and low flows every weekend, with hydropower-peaking flows occurring during weekdays. These "bug flows" are designed to minimally affect hydropower revenue while providing ideal egg laying conditions for aquatic insects on weekends.

\section{Contact}

Theodore Kennedy, USGS Southwest Biological Science Center, tkennedy@usgs.gov, (928) 556-7374

\section{Publications}

Kennedy, T.A., Muehlbauer, J.D., Yackulic, C.B., Lytle, D.A., Miller, S.W., Dibble, K.L., Kortenhoven, E.W., Metcalfe, A.N., and Baxter, C.V., 2016, Flow management for hydropower extirpates aquatic insects, undermining river food webs: BioScience, v. 66, no. 7, p. 561-575, https://doi.org/10.1093/biosci/biw059.

Sabo, J.L., Caron, M., Doucett, R., Dibble, K.L., Ruhi, A., Marks, J.C., Hungate, B.A., and Kennedy, T.A., 2018, Pulsed flows, tributary inputs and food-web structure in a highly regulated river: Journal of Applied Ecology, v. 55, no. 4, p. 1884-1895, https://doi.org/10.1111/1365-2664.13109.

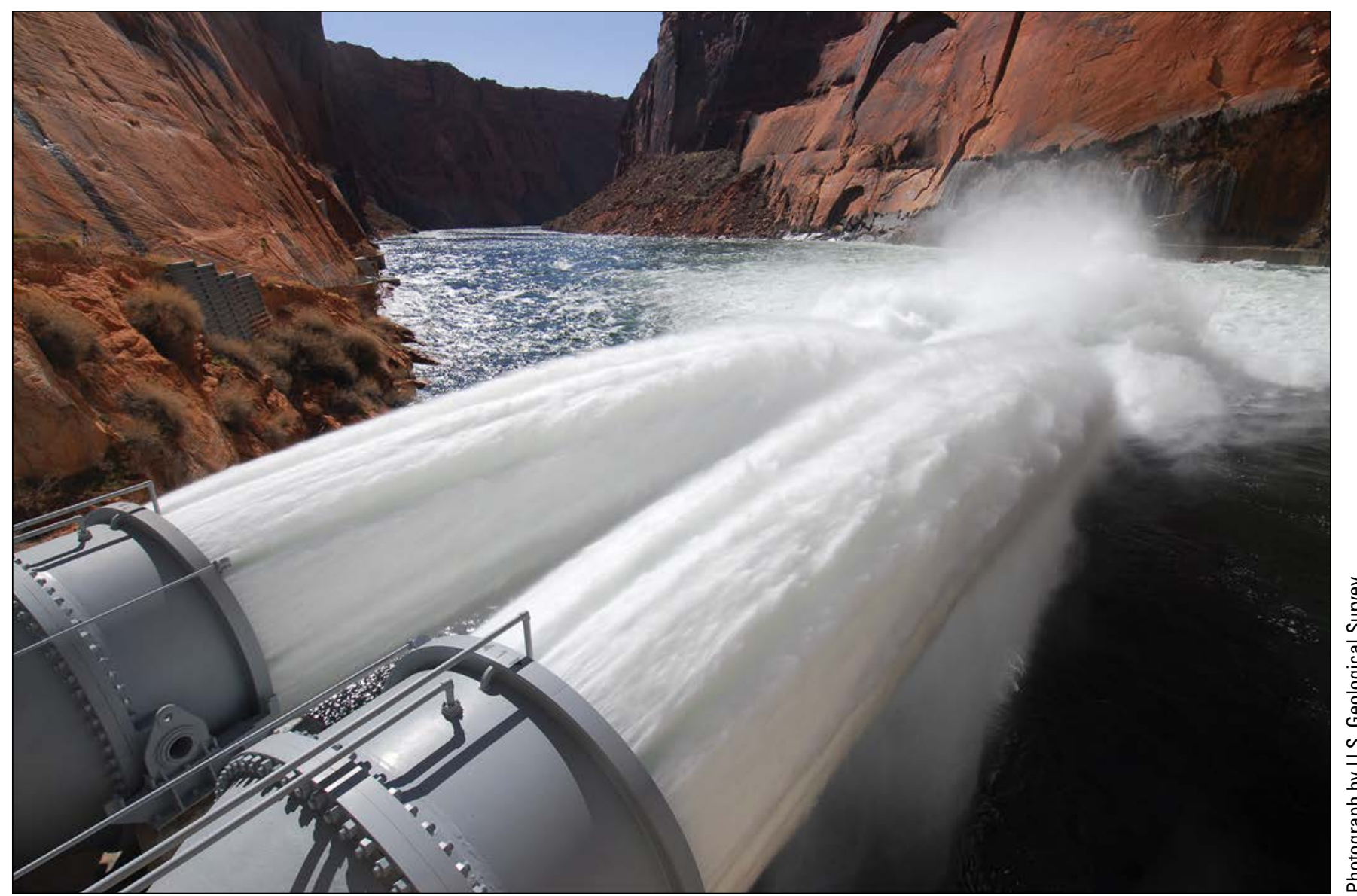

Glen Canyon Dam jet tubes releasing water into the Colorado River for a high flow experiment. 


\section{81. Effects of Dam Operations on Endangered and Introduced Fish Populations}

Glen Canyon Dam operations affect downstream environmental conditions of the Colorado River in Glen and Grand Canyons which, in turn, affect resident aquatic species like fish. USGS scientists assessed the effects of temperature, turbidity, food availability, flow variability, and nonnative fish abundance on endangered humpback chub. Growth models showed that environmental conditions like temperature and duration of turbidity best described growth in sub-adult humpback chub. A model using data from tagged fish measured the effects of rainbow trout, an economically important nonnative sport fish, on humpback chub. Model results showed that rainbow trout have a negative effect on humpback chub survival and, to a lesser degree, on their growth. Understanding the relative importance of various environmental factors on humpback chub allows managers to make informed decisions regarding the operation of Glen Canyon Dam and management actions intended to facilitate the recovery of this endangered species.

\section{Contact}

Charles Yackulic, USGS

Southwest Biological Science

Center, cyackulic@usgs.gov, (928) 556-7379

\section{Publications}

Dibble, K.L., Yackulic, C.B., and Kennedy, T.A., 2018, The influence of water temperature on salmonid recruitment and adult size in tailwaters across western North AmericaData: U.S. Geological Survey data release, https://doi.org/ 10.5066/F72806SS.

Dibble, K.L., Yackulic, C.B., and Kennedy, T.A., 2018, Warm water temperatures and shifts in seasonality increase trout recruitment

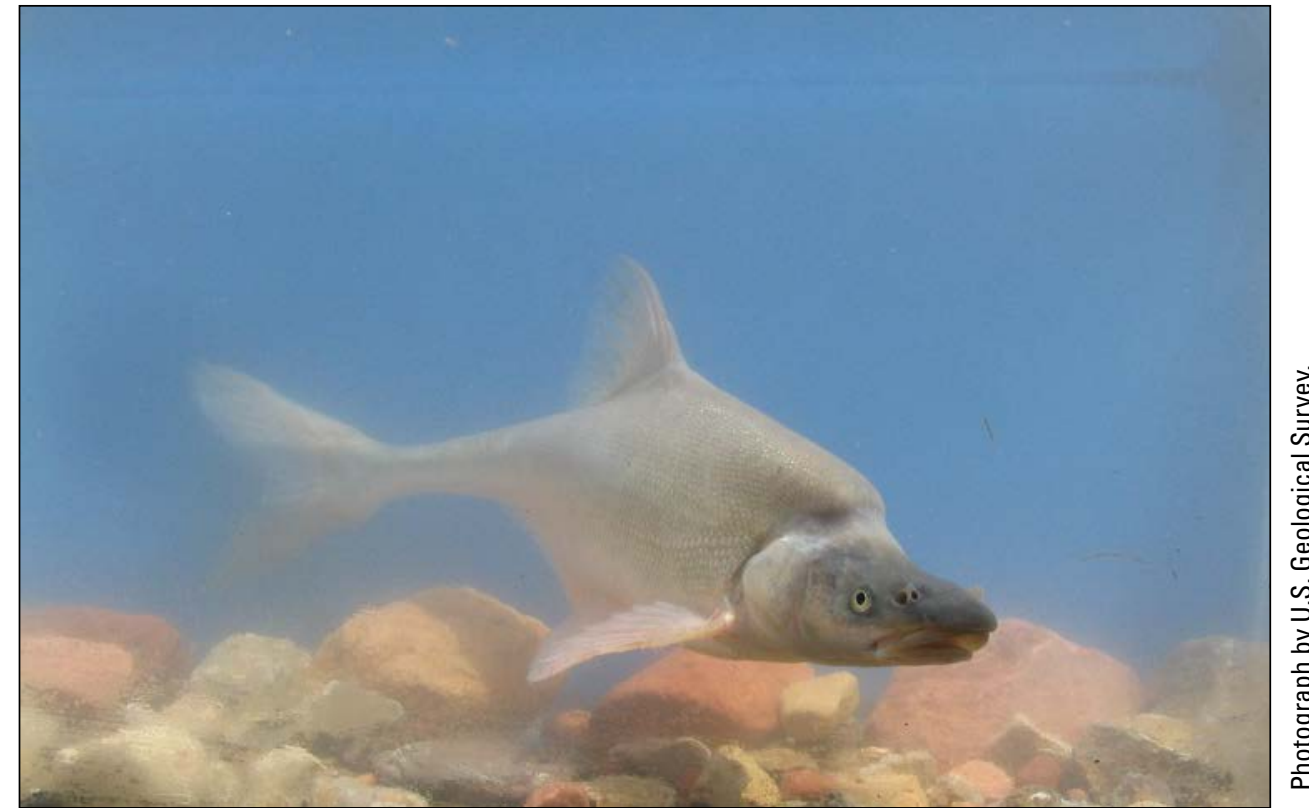

Humpback chub specimen in a laboratory tank. but only moderately decrease adult size in western North American tailwaters: Environmental Biology of Fishes, v. 101, no. 8, p. 1269-1283, https://doi.org/10.1007/s10641-018-0774-7.

Runge, M.C., Yackulic, C.B., Bair, L.S., Kennedy, T.A., Valdez, R.A., Ellsworth, C., Kershner J.L., Rogers, R.S., Trammell, M.A., and Young, K.L., 2018, Brown trout in the Lees Ferry reach of the Colorado River-Evaluation of causal hypotheses and potential interventions: U.S. Geological Survey Open-File Report 2018-1069, 83 p., https://doi.org/10.3133/ofr20181069.

Yackulic, C.B., Korman, J., Yard, M.D., and Dzul, M.C., 2018, Inferring species interactions through joint mark-recapture analysis: Ecology, v. 99, no. 4, p. 812-821, https://doi.org/10.1002/ecy.2166.

\section{Additional Publications}

Dzul, M.C., Yackulic, C.B., Korman, J., Yard, M.D., and Muehlbauer, J.D., 2017, Incorporating temporal heterogeneity in environmental conditions into a somatic growth model: Canadian Journal of Fisheries and Aquatic Sciences, v. 74, no. 3, p. 316-326, https://doi.org/10.1139/cjfas-2016-0056.

Korman, J., Yard, M.D., and Kennedy, T.A., 2017, Trends in rainbow trout recruitment, abundance, survival, and growth during a boom-and-bust cycle in a tailwater fishery: Transactions of the American Fisheries Society, v. 146, no. 5, p. 1043-1057, https://doi.org/10.1080/00028487.2017.1317663.

Yard, M.D., Korman, J., Walters, C.J., and Kennedy, T.A., 2015, Seasonal and spatial patterns of growth of rainbow trout in the Colorado River in Grand Canyon, Arizona: Canadian Journal of Fisheries and Aquatic Sciences, v. 73, no. 1, p. 125-139, https://doi.org/10.1139/cjfas-2015-0102. 


\section{Optimizing Dam Operations and Management}

LU 82. Adaptive Management of Flows From R.L. Harris Dam on the Tallapoosa River, Alabama

A number of hydroelectric dams across the United States are undergoing a Federal Energy Regulatory Commission process for renewing their licenses. Adaptive management may be a viable path to engage stakeholders as part of this process and ensure stakeholder satisfaction with new management options. The USGS worked with the Alabama Department of Conservation and Natural Resources, Alabama Power Company, USFWS, and R.L. Harris Dam Adaptive Management Stakeholders to determine the best management alternatives for attainment of a suite of objectives outlined in a long-term adaptive management program below R.L. Harris Dam, a large, privately owned dam in Alabama. Stakeholders convened an objective-setting workshop to engage a governance structure and developed a decision support model to determine appropriate actions that optimized stakeholder values. The project led to a Federal Energy Regulatory Commission process for renewing the license to operate the dam.

\section{Contact}

Elise Irwin, USGS Alabama Fish and Wildlife Cooperative Research Unit, eirwin@usgs.gov, (334) 844-9190

Publication

Irwin, E.R., ed., 2019, Adaptive management of flows from R.L. Harris Dam (Tallapoosa River, Alabama) — Stakeholder process and use of biological monitoring data for decision making: U.S. Geological Survey Open-File Report 2019-1026, 93 p., https://doi.org/10.3133/ofr20191026.

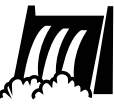

\section{Missouri River Emergent Sandbar Habitat Classification}

Emergent sandbars on the Missouri River are breeding habitat for the endangered interior population of least terns and the threatened northern Great Plains population of piping plovers. The USACE operates several large dams on the river and manages water discharge from these dams for multiple purposes, including hydroelectric energy production and suitable habitat for threatened and endangered species. USGS scientists are using satellite imagery and remote-sensing methods to create maps for use in classifying and quantifying emergent sandbar habitat and to study habitat dynamics in response to fluctuating water levels. These maps are used by the USACE to monitor and manage bare and sparsely vegetated sandbars, critical breeding habitat for these two species. These maps have been incorporated into USACE management plans and are planned to be released annually to the public beginning in 2019. The methods used to create these maps and a database of potential habitats are planned for publication.

\section{Contact}

Mark Sherfy, USGS Northern Prairie Wildlife Research Center, msherfy@usgs.gov, (701) 253-5504

\section{Monitoring Total Dissolved Gas in Hydropower Dams Spills}

Spill water from dams contains supersaturated dissolved gases, a condition created by the turbulent flow conditions attributed to the dam. High dissolved gas concentrations increase mortality to fish below dams. The USGS, in cooperation with the USACE, monitors total dissolved gas at USACE-owned dams in the Columbia and Willamette River systems in Oregon. The data from the study are used in real time by USACE dam operators to ensure total dissolved gas levels in spills meet U.S. Environmental Protection Agency (EPA) criteria.

\section{Contact}

Heather Bragg, USGS Oregon Water Science Center, hmbragg@usgs.gov, (503) 251-3224

\section{Resources}

U.S. Geological Survey, 2016, Lower Columbia River dissolved gas monitoring network: U.S. Geological Survey Oregon Water Science Center website, https://www.usgs.gov/centers/or-water/science/lower-columbia-river-dissolved-gas-monitoringnetwork?qt-science_center_objects=0\#qt-science_center_objects.

U.S. Geological Survey, 2018, USGS water data for the Nation: U.S. Geological Survey National Water Information System database, https://doi.org/10.5066/F7P55KJN. 


\section{Aquatic Invasive Species Control Efforts and Dam Operations}

Nonnative fishes, some potentially invasive, have been introduced in impoundments throughout the United States to create recreational fishing opportunities. The passage of individual fish and other aquatic organisms through dams as part of hydropower operations can lead to invasions of unwanted species. USGS scientists are developing and testing the feasibility of methods such as carbon dioxide and sound to eradicate undesirable species upstream and downstream from dams. The use of carbon dioxide has shown promise as a deterrent strategy for invasive fish species and could be an effective pest management tool to control invasive crayfish such as red swamp and rusty crayfish. The technology will be field tested in Michigan in partnership with the Michigan Department of Natural Resources to eradicate invasive crayfish from small ponds. Current efforts also focus on several fish and mollusks, including four species of nonnative Asian carp, round goby, and Dreissenid mussels (quagga mussels and zebra mussels).

\section{Contact}

Mark Gaikowski, USGS Upper Midwest Environmental Sciences Center, mgaikowski@usgs.gov, (608) 781-6221

\section{Publications}

Cupp, A.R., Erickson, R.A., Fredricks, K.T., Swyers, N.M., Hatton, T.W., and Amberg, J.J., 2017, Responses of invasive silver and bighead carp to a carbon dioxide barrier in outdoor ponds: Canadian Journal of Fisheries and Aquatic Sciences, v. 74, no. 3, p. 297-305, https://doi.org/10.1139/cjfas-2015-0472.

Cupp, A.R., Smerud, J.R., Tix, J.A., Schleis, S.M., Fredricks, K.T., Erickson, R.A., Amberg, J.J., Morrow, W.S., Koebel, C., Murphy, E.A., Vishy, C., and Blodget, K.D., 2018, Field evaluation of carbon dioxide as a fish deterrent at a water management structure along the Illinois River: Management of Biological Invasions, v. 9, p. 299-308, https://doi.org/10.3391/mbi.2018.9.3.12.

Cupp, A.R., Tix, J.A., Smerud J.R., Erickson, R.A., Fredricks, K.T., Amberg, J.J., Suski, C.D., and Wakeman, R., 2017, Using dissolved carbon dioxide to alter the behavior of invasive round goby: Management of Biological Invasions, v. 8, no. 4, p. 567-574, https://doi.org/10.3391/mbi.2017.8.4.12.

Cupp, A.R., Woiak, Z., Erickson, R.A., Amberg, J.J., and Gaikowski, M.P., 2017, Carbon dioxide as an under-ice lethal control for invasive fishes: Biological Invasions, v. 19, no. 9, p. 2543-2552, https://doi.org/10.1007/s10530-017-1462-9.

Donaldson, M.R., Amberg, J., Adhikari, S., Cupp, A., Jensen, N., Romine, J., Wright, A., Gaikowski, M., and Suski, C.D., 2016, Carbon dioxide as a tool to deter the movement of invasive bigheaded carps: Transactions of the American Fisheries Society, v. 145, no. 3, p. 657-670, https://doi.org/10.1080/00028487.2016.1143397.

Waller, D.L., Bartsch, M.R., Fredricks, K.T., Bartsch, L.A., Schleis, S.M., and Lee, S.H., 2016, Effects of carbon dioxide on juveniles of the freshwater mussel (Lampsilis siliquoidea [Unionidae]): Environmental Toxicology and Chemistry, v. 36, no. 3, p. 671-681, https://doi.org/10.1002/etc.3567.

\section{Additional Publications}

Buccola, N.L., Risley, J.C., and Rounds, S.A., 2016, Simulating future water temperatures in the North Santiam River, Oregon: Journal of Hydrology, v. 535, p. 318-330, https://doi.org/10.1016/j.jhydrol.2016.01.062.

Buccola, N.L., Turner, D.F., and Rounds, S.A., 2016, Water temperature effects from simulated dam operations and structures in the Middle Fork Willamette River, western Oregon: U.S. Geological Survey Open-File Report 2016-1159, 39 p., https://doi.org/10.3133/ofr20161159.

Eyler, S.M., Welsh, S.A., Smith, D.R., and Rockey, M.M., 2016, Downstream passage and impact of turbine shutdowns on survival of silver American eels (Anguilla rostrata) at five hydroelectric dams on the Shenandoah River: Transactions of the American Fisheries Society, v. 145, no. 5, p. 964-976, https://doi.org/10.1080/00028487.2016.1176954.

Heck, M.P., Schultz, L.D., Hockman-Wert, D., Dinger, E.C., and Dunham, J.B., 2018, Monitoring stream temperatures-A guide for non-specialists: U.S. Geological Survey Techniques and Methods, book 3, chap. A25, 76 p., https://doi.org/10.3133/tm3A25.

Smith, D.R., Fackler, P.L., Eyler, S.M., Ortiz, L.V., and Welsh, S.A., 2017, Optimization of decision rules for hydroelectric operation to reduce both eel mortality and unnecessary turbine shutdown-A search for a win-win solution: River Research and Applications, v. 33, no. 8, p. 1279-1285, https://doi.org/10.1002/rra.3182. 


\section{Terrestrial and Aquatic Habitats and Ecosystem Functions}

Energy development creates a footprint on the terrestrial landscape that can affect wildlife species through changes in the amount and quality of available habitat. Habitat fragmentation may affect species abundance, behavior, and persistence, among other ecological factors. Oil and gas pads, coal and uranium mining operations, and renewable energy facilities occupy a relatively small footprint on the landscape, but the network of roads, power lines, and pipelines needed to connect and support them increases the anthropogenic factors associated with these facilities. USGS scientists are assessing land-use changes associated with energy development and their direct and indirect effects on the quality and quantity of wildlife habitat. Research is also focused on the development of strategies that enhance wildlife habitats while facilitating responsible development.

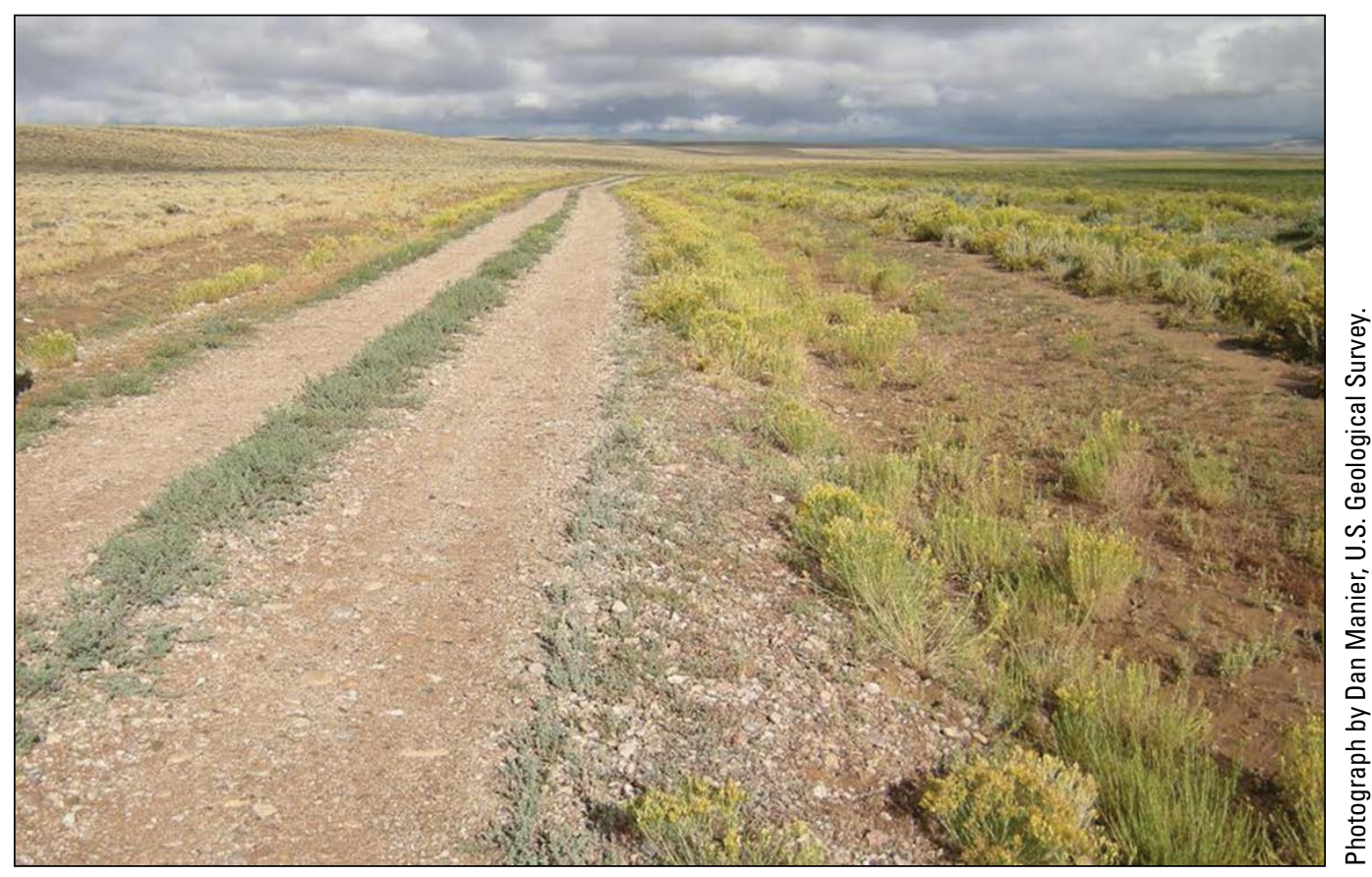

A country road near Big Piney, Wyoming.

\section{Effects on Terrestrial Habitats}

\section{Geographic Context in Wind Energy Land Transformation}

USGS scientists are studying changes in land-cover associated with new energy facilities and how the impacts change depending on where the facilities are located. Research is focused on overall levels of land transformation and alterations of road networks and how these changes affect the amounts and patterns of undisturbed land cover. This information can assist managers with decisions on how to create opportunities for wind energy production that minimize land-cover change through effective siting.

\section{Contact}

Jay Diffendorfer, USGS Geosciences and Environmental Change Science Center, jediffendorfer@usgs.gov, (303) 236-5369

\section{Publication}

Diffendorfer, J.E., Dorning, M.A., Keen, J.R., Kramer, L.A., and Taylor, B.V., 2019, Geographic context affects the landscape change and fragmentation caused by wind energy facilities: PeerJ, v. 7, e7129, https://doi.org/10.7717/peerj.7129. 


\section{Wyoming Wind Energy Disturbance Mapping}

USGS scientists are quantifying, for the WLCI, land-surface disturbance associated with development and operation of wind facilities. In this analysis, scientists are incorporating all infrastructure data associated with wind energy development, surface disturbance, and re-vegetation or reclamation following initial wind-facility development. Results will document the amount and pattern of disturbance over time during the development and operation of facilities in Wyoming. This research includes assessment of changes in land-surface temperature, evapotranspiration, and vegetation around wind turbines. This information may be useful to developers and land managers in planning and assessing future wind projects.

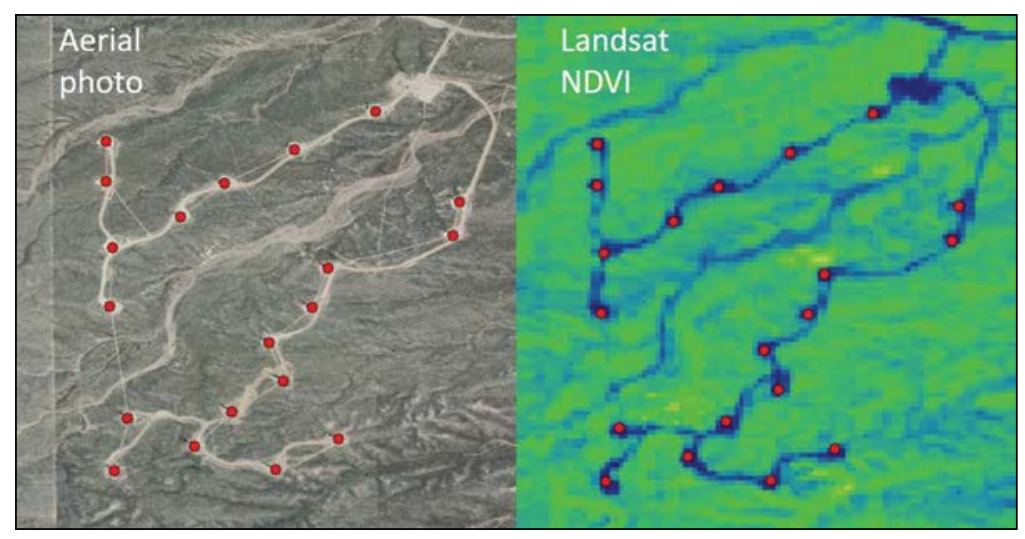

Disturbances from wind farms are visible in imagery from aircraft (left) and satellite (right). Red dots mark turbine locations.

\section{Contact}

Aaron Johnston, USGS Northern Rocky Mountain Science Center, ajohnston@usgs.gov, (406) 994-7158

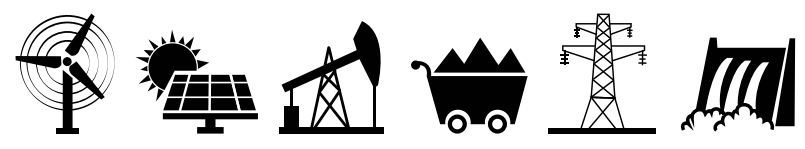

\section{Energy Futures for Wyoming}

As part of the WLCI, the USGS is mapping the locations and extents of potential electricity-generating resources in Wyoming. This work includes mapping resources, such as natural gas, coal, wind, and hydropower, as well as transmission and transportation corridors. Results of this work can be used to inform the WLCI and other energy-related studies. More broadly, USGS researchers are developing an energy-assessment framework and methods that can be used in other regions.

\section{Contact}

Zachary H. Bowen, USGS Fort Collins Science Center, bowenz@usgs.gov, (970) 226-9218

\section{Publication}

Zeigenfuss, L.C., Aikens, E., Aldridge, C.L., Anderson, P.J., Assal, T.J., Bowen, Z.H., Chalfoun, A.D., Chong, G.W., EddyMiller, C.A., Germaine, S.S., Graves, T., Homer, C.G., Huber, C.C., Johnston, A., Kauffman, M.J., Manier, D.J., McShane, R.R., Miller, K.A., Monroe, A.P., Ortega, A., Walters, A.W., and Wyckoff, T.B., 2019, U.S. Geological Survey science for the Wyoming Landscape Conservation Initiative_-2017 annual report: U.S. Geological Survey Open-File Report 2018-1188, 57 p., https://doi.org/10.3133/ofr20181188. 


\section{Aeolian Dust Associated With Oil and Gas Infrastructure in Sagebrush Ecosystems}

The rapid expansion of energy development on Federal lands in southwestern Wyoming began in the early 2000 s. Partners with the WLCI expressed the need to better understand whether dust generated from energy development could be affecting wildlife and their habitats. USGS is conducting a long-term study of road dust and soil movement associated with a large energy development in south-central Wyoming. USGS scientists deployed dust samplers and collected vegetation samples to estimate dust flux and soil movement across a gradient of development to evaluate dust generation and distribution patterns. During 2018, the USGS continued to collect dust samples and quantitatively estimated percent bare ground and plant cover at each collection site. This study can be used by resource managers in Wyoming and elsewhere in the sagebrush steppe region to inform potential strategies to mitigate impacts attributed to dust.

\section{Contacts}

Pat Anderson, USGS Fort Collins Science Center, andersonpj@usgs.gov, (970) 226-9488

Daniel Manier, USGS Fort Collins Science Center, manierd@usgs.gov, (970) 226-9466

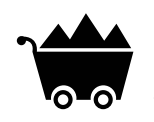

\section{Potential Effects of Uranium Mining in the Grand Canyon}

USGS scientists are working to better understand the potential effects of uranium and other trace elements associated with uranium mining on regional water resources, native plants and animals, and cultural and tribal resources. Wildliferelated studies include characterizing the distribution of uranium and co-occurring elements in terrestrial and aquatic habitats and their potential effects on biota by studying exposure pathways to endemic species and by collecting data to refine bioaccumulation models. Researchers are conducting species surveys, including the use of environmental DNA (eDNA) metagenomic methods, to detect vertebrate and invertebrate species living in and near surface waters near mining activity. Studies are also underway to examine methods of minimizing toxicity to organisms in mine ponds. Finally, researchers are investigating the ability of novel reclamation techniques to stabilize soil at reclaimed mines. Information from these studies can be used by land managers, regulators, industry, and others to understand and mitigate the potential environmental effects of developing brecciapipe uranium resources.

\section{Contacts}

Jo Ellen Hinck, USGS Columbia Environmental Research Center, jhinck@usgs.gov, (573) 876-1808

Danielle Cleveland, USGS Columbia Environmental Research Center, dcleveland@usgs.gov, (573) 876-1858

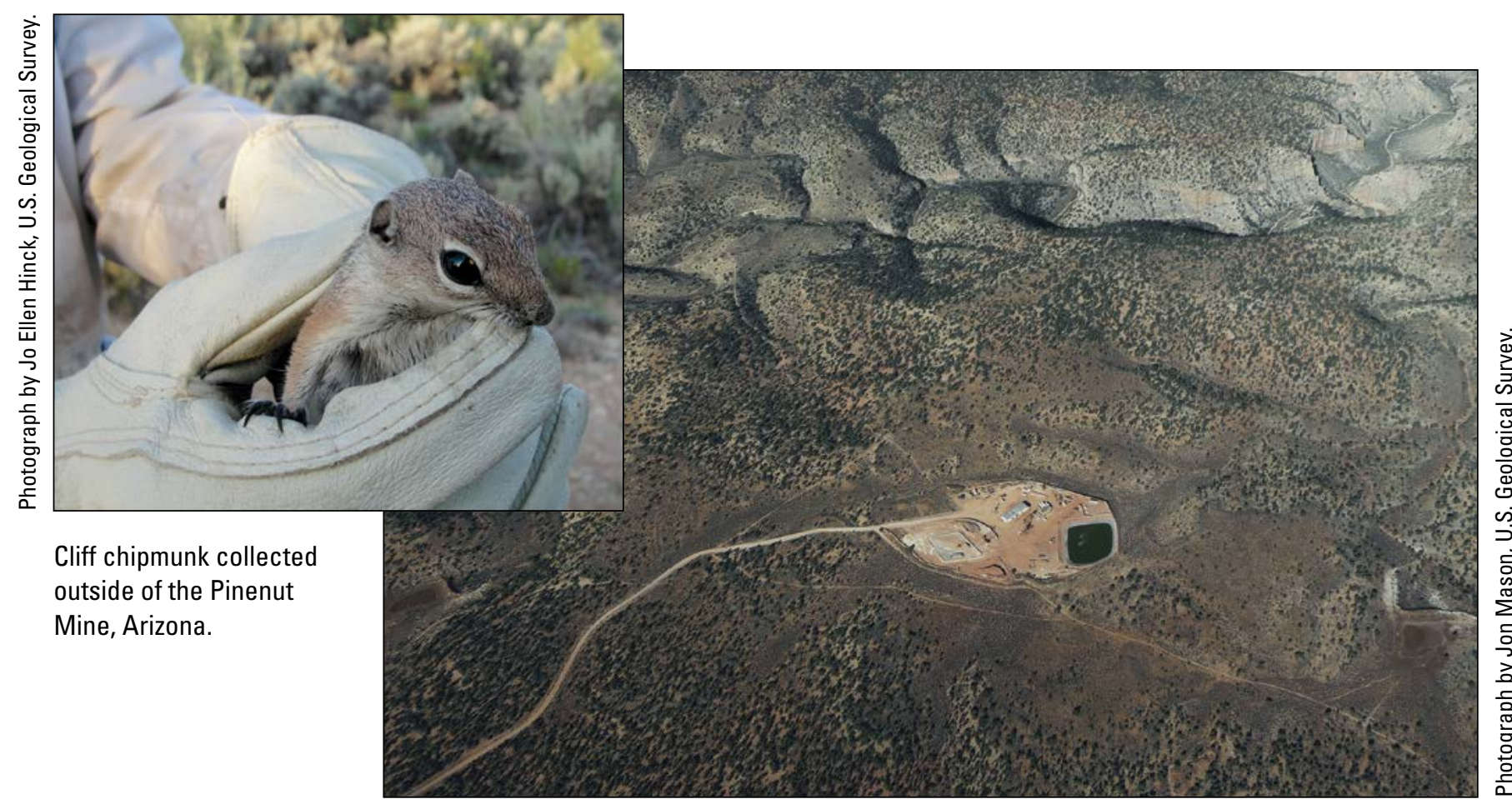

Aerial view of Pinenut Mine and surrounding area, Arizona. 


\section{Publications}

Cleveland, D., Hinck, J.E., and Lankton, J.S., 2019, Assessment of chronic low-dose elemental and radiological exposures of biota at the Kanab North uranium mine site in the Grand Canyon watershed: Integrated Environmental Assessment and Management: v. 15, no. 1, p. 112-125, https://doi.org/10.1002/ieam.4095.

Hinck, J.E., Cleveland, D., Brumbaugh, W.G., Linder, G., and Lankton, J., 2017, Pre-mining trace element and radiation exposure to biota from a breccia pipe uranium mine in the Grand Canyon (Arizona, USA) watershed: Environmental Monitoring and Assessment, v. 189, article no. 56, 23 p., https://doi.org/10.1007/s10661-017-5765-1.

Hinck, J.E., Hossack, B.R., and Honeycutt, R.K., 2017, Amphibian acoustic data from the Arizona 1, Pinenut, and Canyon breccia pipe uranium mines in Arizona: U. S. Geological Survey data release, https://doi.org/10.5066/F71834QW.

Klymus, K.E., Richter, C.A., Thompson, N., and Hinck, J.E., 2017, Metabarcoding of environmental DNA samples to explore the use of uranium mine containment ponds as a water source for wildlife: Diversity, v. 9, no. 4, article no. 54, 18 p., https://doi.org/10.3390/d9040054.

Minter, K.M., Jannik, G.T., Hinck, J.E., Cleveland, D., Kubilius, W.P., and Kuhne, W.W., 2019, Biota dose assessment of small rodents sampled near breccia pipe uranium mines in the Grand Canyon watershed: Health Physics, v. 117, no. 1, p. 20-27, https://doi.org/10.1097/HP.0000000000001041.

\section{Shale Gas Development in the Appalachians}

Since 2005, the Marcellus Shale Formation in the Appalachian Basin has experienced exponential shale gas development, and development is projected to increase. USGS researchers and university collaborators have completed a series of studies to evaluate wildlife response to shale gas development that can help Federal and State land managers minimize effects on wildlife. The studies focused on the long-term response of an avian community in West Virginia to forest loss and fragmentation from shale gas development and the demography of Louisiana waterthrush and their benthic macroinvertebrate prey. Despite relatively small site-wide forest loss, waterthrush site quality and nest success declined as shale gas development increased. Avian community composition changed in response to shale gas development. Results from these studies can inform best management practices for gas development.

\section{Contact}

Petra Wood, USGS West Virginia Cooperative Fish and Wildlife Research Unit, pbwood@wvu.edu, (304) 293-5090

\section{Publications}

Farwell, L.S., Wood, P.B., Brown, D.J., and Sheehan, J., 2019, Proximity to unconventional shale gas infrastructure alters breeding bird abundance and distribution: The Condor, advance article posted June 11, 2019, 20 p., https://doi.org/10.1093/ condor/duz020.

Farwell, L.S., Wood, P.B., Sheehan, J., and George, G.A., 2016, Shale gas development effects on the songbird community in a central Appalachian forest: Biological Conservation, v. 201, p. 78-91, https://doi.org/10.1016/j.biocon.2016.06.019.

Frantz, M.W., Wood, P.B., and Merovich, G.T., Jr., 2018, Demographic characteristics of an avian predator, Louisiana Waterthrush (Parkesia motacilla), in response to its aquatic prey in a central Appalachian USA watershed impacted by shale gas development: PLOS ONE, v. 13, no. 11, e0206077, 19 p., https://doi.org/10.1371/journal.pone.0206077.

Frantz, M.W., Wood, P.B., Sheehan, J., and George, G., 2018, Demographic response of Louisiana waterthrush, a stream obligate songbird of conservation concern, to shale gas development: The Condor, v. 120, no. 2, p. 265-282, https://doi.org/10.1650/CONDOR-17-130.1.

Frantz, M.W., Wood, P.B., Sheehan, J., and George, G., 2019, Louisiana waterthrush (Parkesia motacilla) survival and site fidelity in an area undergoing shale gas development: Wilson Journal of Ornithology, v. 131, no. 1, p. 84-95, https://doi.org/10.1676/18-6.

Latta, S.C., Marshall, L.C., Frantz, M.W., and Toms, J.D., 2015, Evidence from two shale regions that a riparian songbird accumulates metals associated with hydraulic fracturing: Ecosphere, v. 6, no. 9, article no. 144, 10 p., https://doi.org/10.1890/es14-00406.1.

Wood, P.B., Frantz, M.W., and Becker, D.A., 2016, Louisiana waterthrush and benthic macroinvertebrate response to shale gas development: Journal of Fish and Wildlife Management, v. 7, no. 2, p. 423-433, https://doi.org/10.3996/092015-JFWM-084. 


\section{Terrestrial Impacts of Mountaintop Mining}

Ecological research on mountaintop mining has been focused on aquatic impacts because the overburden, or mountaintop, is disposed of in nearby valleys, leading to a wide range of water-quality impacts on streams. Numerous impacts on the terrestrial environment from mountaintop mining also have been largely overlooked, even though they are no less wide ranging, severe, and multifaceted. USGS scientists are reviewing the impacts of mountaintop mining on the terrestrial environment in studies that complement existing research focused on impacts to aquatic environments. These completed studies can assist managers and regulators in evaluating the full impacts of mountaintop mining on the terrestrial environment.

\section{Contact}

Petra Wood, USGS West Virginia Cooperative Fish and Wildlife Research Unit, pbwood@wvu.edu, (304) 293-5090

\section{Publications}

Becker, D.A., Wood, P.B., Strager, M.P., and Mazzarella, C., 2015, Impacts of mountaintop mining on terrestrial ecosystem integrity-Identifying landscape thresholds for avian species in the central Appalachians, United States: Landscape Ecology v. 30, no. 2, p. 339-356, https://doi.org10.1007/s10980-014-0134-8.

Margenau, E.L., Wood, P.B., Weakland, C.A., and Brown, D.J., 2019, Trade-offs relating to grassland and forest mine reclamation approaches in the central Appalachian region and implications for the songbird community: Avian Conservation and Ecology, v. 14, no. 1, article no. 2, 14 p., https://doi.org/10.5751/ACE-01304-140102.

Williams, J.M., Brown, D.J., and Wood, P.B., 2017, Responses of terrestrial herpetofauna to persistent, novel ecosystems resulting from mountaintop removal mining: Journal of Fish and Wildlife Management, v. 8, no. 2, p. 387-400, https://doi.org/10.3996/102016-JFWM-079.

Wood, P.B., and Ammer, F.K., 2015, Grasshopper sparrow reproductive success and habitat use on reclaimed surface mines varies by age of reclamation: Wildlife Society Bulletin, v. 39, no. 3, p. 512-520, https://doi.org/10.1002/wsb.563.

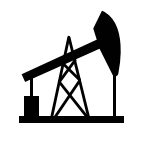

\section{Ecological Effects of Brine Contamination in the Prairie Pothole Region}

Energy production in the Williston Basin results in the co-production of highly saline water, or brine. USGS researchers examined the effects of contamination from production waters derived from oil and gas development on macroinvertebrate communities. Scientists sampled 155 wetlands across a contamination gradient in the Prairie Pothole Region (PPR) and collected samples to determine macroinvertebrate taxonomic richness, wetland salinity, and chloride levels. Across this gradient, contaminated wetlands had lower invertebrate richness, diversity, and evenness; however, predictable, systematic shifts in invertebrate community structure were not detected.

\section{Contact}

Todd Preston, USGS Northern Rocky Mountain Science Center, tmpreston@usgs.gov, (406) 994-5034

Below: Saline wastewater contamination from legacy energy development sites lead to long-term salinization of wetlands in the Prairie Pothole Region in central North America. Image from Preston and others (2019), Creative Commons 4.0 license.
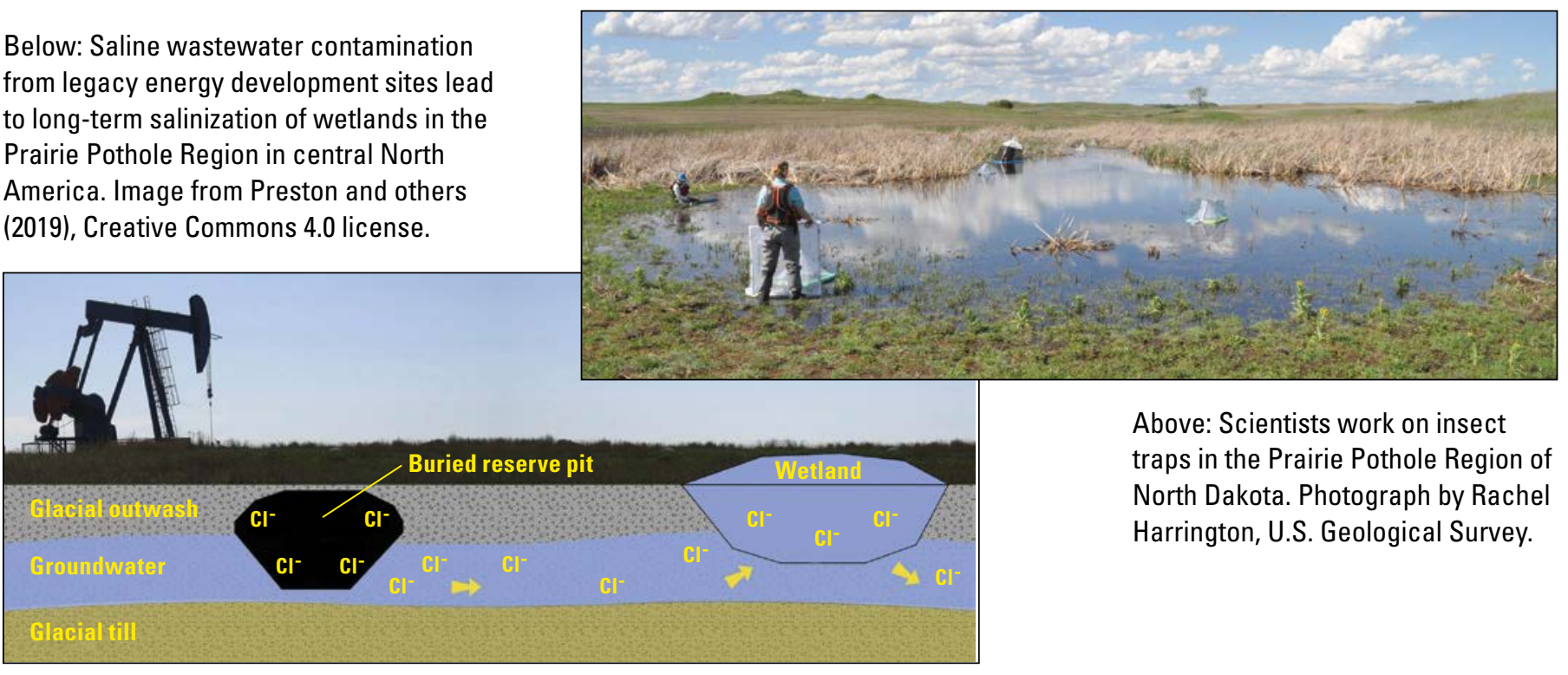

Above: Scientists work on insect traps in the Prairie Pothole Region of North Dakota. Photograph by Rachel Harrington, U.S. Geological Survey. 


\section{Publications}

Preston, T.M., Anderson, C.W., Thamke, J.N., Hossack, B.R., Skalak, K.J., and Cozzarelli, I.M., 2019, Predicting attenuation of salinized surface- and groundwater-resources from legacy energy development in the Prairie Pothole Region: Science of the Total Environment, v. 690, p. 522-533, https://doi.org/10.1016/j.scitotenv.2019.06.428.

Preston, T.M., Borgreen, M.J., and Ray, A.M., 2018, Effects of brine contamination from energy development on wetland macroinvertebrate community structure in the Prairie Pothole Region: Environmental Pollution, v. 239, p. 722-732, https://doi.org/10.1016/j.envpol.2018.04.088.

Preston, T.M., and Ray, A.M., 2016, Effects of energy development on wetland plants and macroinvertebrate communities in Prairie Pothole Region wetlands: Journal of Freshwater Ecology, v. 32, no. 1, p. 29-34, https://doi.org/10.1080/02705060.2016.1231137.

\section{Additional Publications}

Martinez, C., and Preston, T.M., 2018, Oil and gas development footprint in the Piceance Basin, western Colorado: Science of the Total Environment, v. 616-617, p. 355-362, https://doi.org/10.1016/j.scitotenv.2017.10.280.

Post van der Burg, M., Vining, K.C., and Frankforter, J.D., eds., 2017, Potential effects of energy development on environmental resources of the Williston Basin in Montana, North Dakota, and South Dakota: U.S. Geological Survey Scientific Investigations Report 2017-5070A-D, variously paged. [Only chap. D available at https://doi.org/10.3133/sir20175070.]

Preston, T.M., 2015, Presence and abundance of non-native plant species associated with recent energy development in the Williston Basin: Environmental Monitoring and Assessment, v. 187, article no. 200, 16 p., https://doi.org/10.1007/s10661015-4408-7.

Preston T.M., and Kim, K., 2016, Land cover changes associated with recent energy development in the Williston BasinNorthern Great Plains, U.S.A.: Science of the Total Environment, v. 566-567, p. 1511-1518, https://doi.org/10.1016/j. scitotenv.2016.06.038.

Young, J., Maloney, K.O., Slonecker, E.T., Milheim, L.E., and Siripoonsup, D., 2018, Canopy volume removal from oil and gas development activity in the upper Susquehanna River Basin in Pennsylvania and New York (U.S.A.) - An assessment using lidar data: Journal of Environmental Management, v. 222, p. 66-75, https://doi.org/10.1016/j.jenvman.2018.05.041.

\section{Effects on Aquatic Habitats}

\section{Effects of Acid Deposition From Energy Production on Fish and Other Aquatic Species}

Watersheds across the United States, including those in the Adirondack Mountains in northern New York, receive high levels of acid deposition of nitrogen and sulfur oxides emitted from power plants and the transportation sector. Acid deposition has been shown to increase acidity and aluminum concentrations in soils and surface waters and affect forest health as well as fish and macroinvertebrate assemblages. USGS scientists are working alongside local, State, and Federal cooperators to characterize the influence of acid-base chemistry on the condition of fish and macroinvertebrate assemblages in lakes and streams in the Adirondacks and other regions, information that is needed for critical loads analyses. The USGS plans to compile and analyze chemical and biological data from multiple datasets and evaluate variations in the health of biological assemblages in streams and lakes that are associated with ongoing impacts and recovery from acid deposition. This research is needed to estimate threshold or target deposition loads of nitrogen and sulfur to watersheds, below which significant harmful effects on sensitive elements of terrestrial and aquatic ecosystems are not expected to occur.

\section{Contacts}

Barry Baldigo, USGS New York Water Science Center, bbaldigo@usgs.gov, (518) 285-5605

Scott George, USGS New York Water Science Center, sgeorge@usgs.gov, (518) 285-5639

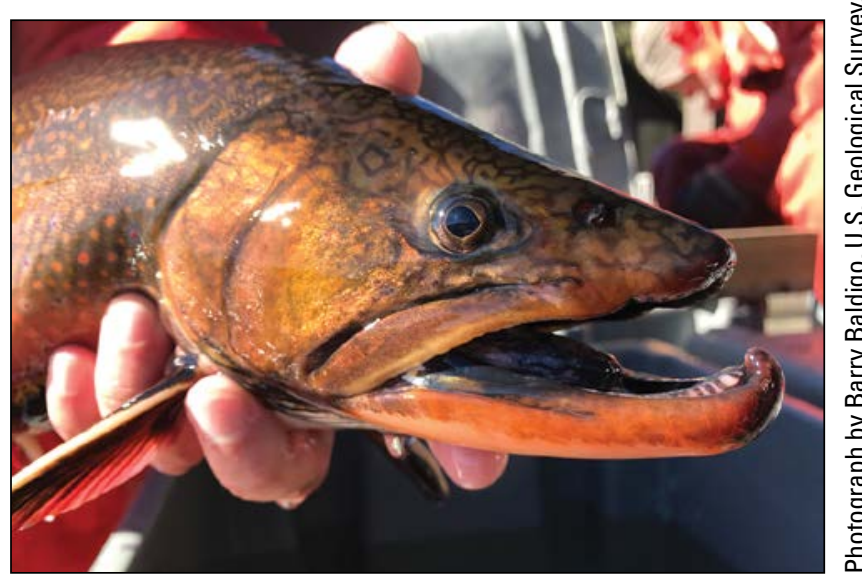

Brook trout collected from an Adirondack lake. 


\section{Publications}

Baldigo, B.P., George, S.D., Lawrence, G.B., and Paul, E.A., 2019, Acidification impacts and goals for gauging recovery of brook trout populations and fish communities in streams of the western Adirondack Mountains, New York, USA: Transactions of the American Fisheries Society, v. 148, no. 2, p. 373-392, https://doi.org/10.1002/tafs.10137.

Baldigo, B.P., George, S.D., Sullivan, T.J., Driscoll, C.T., Burns, D.A., Shao, S., and Lawrence, G.B., 2019, Probabilistic relations between acid-base chemistry and fish assemblages in streams of the western Adirondack Mountains, New York, USA: Canadian Journal of Fisheries and Aquatic Sciences, e-First article posted February 1, 2019, 14 p., https://doi.org/10.1139/cjfas-2018-0260.

Baldigo, B.P., Kulp, M.A., and Schwartz, J.S., 2018, Relationships between indicators of acid-base chemistry and fish assemblages in streams of the Great Smoky Mountains National Park: Ecological Indicators, v. 88, p. 465-484, https://doi.org/10.1016/j.ecolind.2018.01.021.

George, S.D., and Baldigo, B.P., 2018, Adirondack and Catskill stream-fish survey dataset: U.S. Geological Survey data release, https://doi.org/10.5066/F70C4V25.

George, S.D., Baldigo, B.P., Lawrence, G.B., and Fuller, R.L., 2018, Effects of watershed and in-stream liming on macroinvertebrate communities in acidified tributaries to an Adirondack lake: Ecological Indicators, v. 85, p. 1058-1067, https://doi.org/10.1016/j.ecolind.2017.11.048.

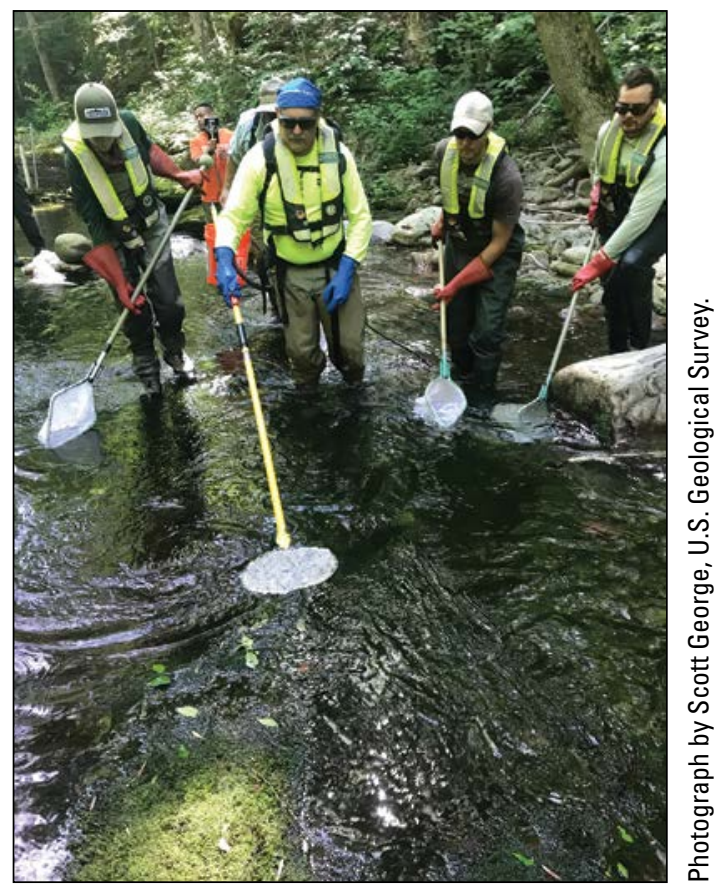

U.S. Geological Survey staff surveying fish assemblages in a Catskill Mountain stream.

George, S.D., Baldigo, B.P., and Stich, D.S., 2019, Temporal variability in stream fish assemblage metrics and implications for long-term monitoring: Ecological Indicators, v. 101, p. 661-669, https://doi.org/10.1016/j.ecolind.2019.01.055.

Josephson, D.C., Lawrence, G.B., George, S.D., Siemion, J., Baldigo, B.P., and Kraft, C., 2019, Response of water chemistry and young-of-year brook trout to channel and watershed liming in streams showing lagging recovery from acidic deposition: Water, Air, and Soil Pollution, v. 230, article no. 144, 15 p., https://doi.org/10.1007/s11270-019-4186-X.

Smith, A.J., Baldigo, B.P., Duffy, B.T., George, S.D., and Dresser, B., 2019, Resilience of benthic macroinvertebrates to extreme floods in a Catskill Mountain river, New York, USA-Implications for water quality monitoring and assessment: Ecological Indicators, v. 104, p. 107-115, https://doi.org/10.1016/j.ecolind.2019.04.057.

\section{Effects of Water Stress From Hydraulic Fracturing on Aquatic Biodiversity and Ecosystem Services in Arkansas}

Demand for high-volume, short-duration water withdrawals could create water stress for aquatic organisms in streams sourced for hydraulic fracturing fluids in Arkansas. The USGS and partners estimated potential water stress by using permitted water withdrawal volumes and actual water withdrawals compared to monthly median, low, and high streamflows. Future water stress was predicted to occur in fewer catchments important for drinking water and species of conservation concern due to the decline in new well installations and increased use of recycled water. Accessible and precise withdrawal and streamflow data are critical to assess and mitigate water stress in streams that experience high-volume withdrawals.

\section{Contact}

Kelly O. Maloney, USGS Leetown Science Center, kmaloney@usgs.gov, (304) 724-4579

\section{Publication}

Entrekin, S., Trainor, A., Saiers, J., Patterson, L., Maloney, K.O., Fargione, J., Kiesecker, J., Baruch-Mordo, S., Konschnik, K., Wiseman, H., Nicot, J.-P., and Ryan, J.N., 2018, Water stress from high-volume hydraulic fracturing potentially threatens aquatic biodiversity and ecosystem services in Arkansas, United States: Environmental Science and Technology, v. 52, no. 4, p. 2349-2358, https://doi.org/10.1021/acs.est.7b03304. 


\section{Potential Toxicity Associated With Produced Waters From Oil and Gas Activity}

The USGS and partners are investigating the potential effects of oil and gas activity on aquatic resources by measuring the levels of inorganic (including salts) and organic compounds in streams following spills or downstream from wastewater facilities. Studies assess toxic thresholds in the laboratory (mimicking field conditions) and potential effects on biological organisms in the field. The USGS is also studying the potential shifts in microbial function, which can alter ecosystem processes, such as nutrient cycling, and can alter the resiliency of a community to perturbation. Results can provide methods for water and sediment monitoring, insight for science support during spills, effective post-spill clean-up practices, and threshold determinations for effects of wastewater discharges on aquatic resources in important rearing areas for migratory waterfowl.

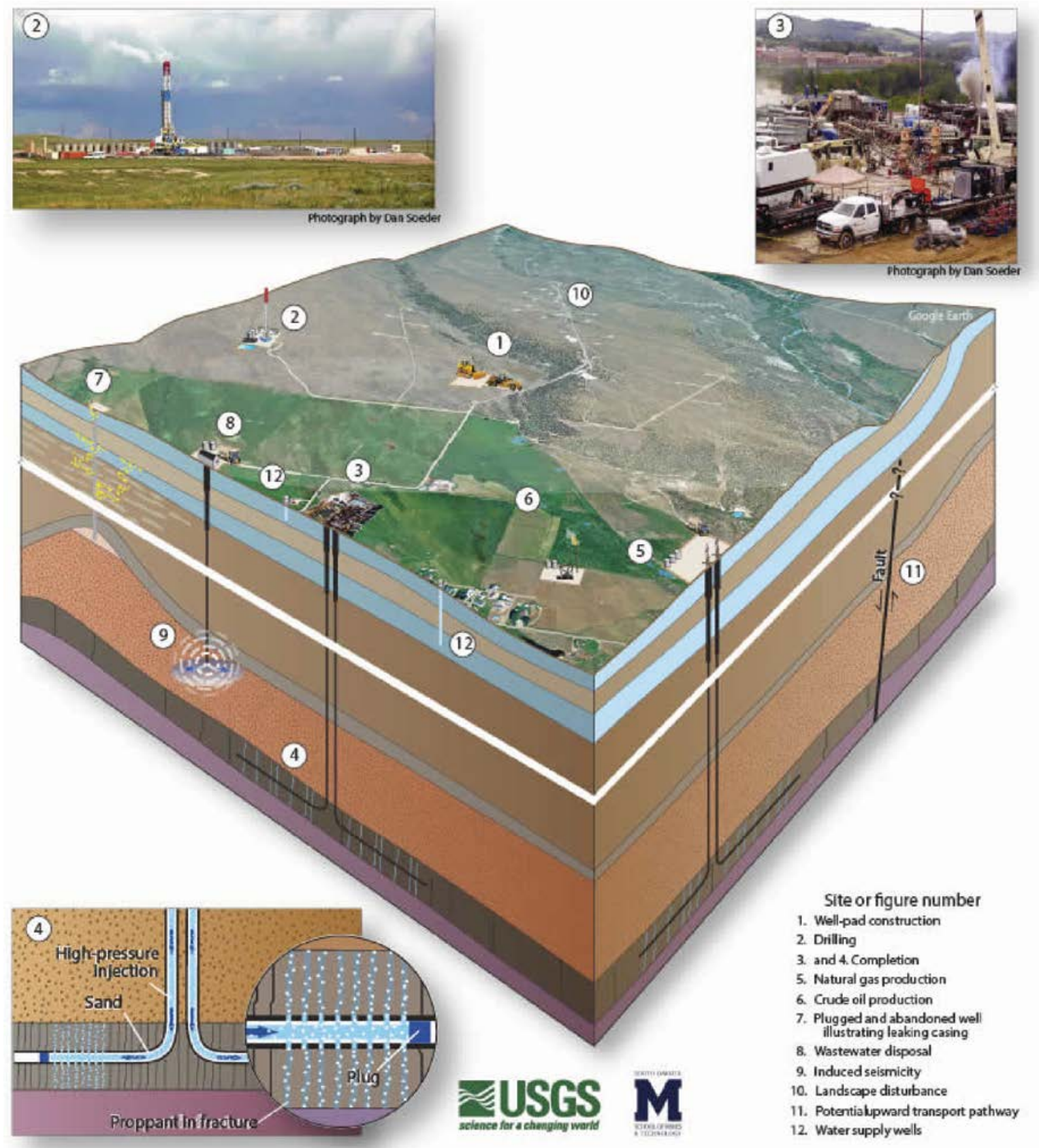

Schematic diagram illustrating unconventional oil and gas (UOG) development activities relevant to research on human-health and environmental impacts (not to scale): well-pad construction (1); drilling (2); completion/stimulation $(3,4)$; production of natural gas (5) and oil (6) with well casings designed to protect drinking-water aquifers; ultimate closure (plug and abandon), illustrating legacy well with leaking casing (7); wastewater disposal (8); induced seismicity (9); landscape disturbance (10); and potential for transport pathways from deep to shallow formations (11). Also represented are water supply wells in shallow and deep aquifers (12). Image from Soeder and Kent (2018). 


\section{Contacts}

Isabelle M. Cozzarelli, USGS Water Resources Mission Area, icozzare@usgs.gov, (703) 648-5899

Aïda Farag, USGS Columbia Environmental Research Center, aida_farag@usgs.gov, (307) 733-2314

Denise M. Akob, USGS Water Resources Mission Area, dakob@usgs.gov, (703) 648-5819

\section{Publications}

Akob, D.M., Mumford, A.C., Orem, W., Engle, M.A., Klinges, J.G., Kent, D.B., and Cozzarelli, I.M., 2016, Wastewater disposal from unconventional oil and gas development degrades stream quality at a West Virginia injection facility: Environmental Science and Technology, v. 50, no. 11, p. 5517-5525, https://doi.org/10.1021/acs.est.6b00428.

Cozzarelli, I.M., Skalak, K.J., Kent, D.B., Engle, M.A., Benthem, A., Mumford, A.C., Haase, K., Farag, A., Harper, D., Nagel, S.C., Iwanowicz, L.R., Orem, W.H., Akob, D.M., Jaeschke, J.B., Galloway, J., Kohler, M., Stoliker, D.L., and Jolly, G.D., 2017, Environmental signatures and effects of an oil and gas wastewater spill in the Williston Basin, North Dakota: Science of the Total Environment, v. 579, p. 1781-1793, https://doi.org/10.1016/j.scitotenv.2016.11.157.

Fahrenfeld, N.L., Delos Reyes, H., Eramo, A., Akob, D.M., Mumford, A.C., and Cozzarelli, I.M., 2016, Shifts in microbial community structure and function in surface waters impacted by unconventional oil and gas wastewaters revealed by metagenomics: Science of the Total Environment, v. 580, p. 1205-1213, https://doi.org/10.1016/j.scitotenv.2016.12.079.

Mumford A.C., Akob, D.M., Klinges, J.G., and Cozzarelli, I.M., 2018, Common hydraulic fracturing fluid additives alter the structure and function of anaerobic microbial communities: Applied and Environmental Microbiology, v. 84, no. 8, e02729-17, 16 p., https://doi.org/10.1128/AEM.02729-17.

Orem, W., Varonka, M., Crosby, L., Haase, K., Loftin, K., Hladik, M., Akob, D.M., Tatu, C., Mumford, A., Jaeschke, J., Bates, A., Schell, T., and Cozzarelli, I., 2017, Organic geochemistry and toxicology of a stream impacted by unconventional oil and gas wastewater disposal operations: Applied Geochemistry, v. 80, p. 155-167, https://doi.org/10.1016/j. apgeochem.2017.02.016.

Rose, L.D., Akob, D.M., Tuberty, S.R., Corsi, S.R., De Cicco, L.A., Colby, J.D., and Martin, D.J., 2019, Use of high-throughput screening results to prioritize chemicals for potential adverse biological effects within a West Virginia watershed: Science of the Total Environment, v. 677, p. 362-372, https://doi.org/10.1016/j.scitotenv.2019.04.180.

Soeder, D.J., and Kent, D.B., 2018, When oil and water mix - Understanding the environmental impacts of shale development: GSA Today, v. 28, no. 9, p. 4-10, https://doi.org/10.1130/GSATG361A.1.

Wang, N., Kunz, J.L., Cleveland, D., Steevens, J.A., and Cozzarelli, I.M., 2019, Biological effects of elevated major ions in surface water contaminated by a produced water from oil production: Archives of Environmental Contamination and Toxicology, v. 76, no. 4, p. 670-677, https://doi.org/10.1007/s00244-019-00610-3. 


\section{Vulnerability of Brook Trout Streams to Shale Gas Development in the Upper Susquehanna River Basin}

The Upper Susquehanna River Basin drains parts of Pennsylvania and New York and includes many high-quality and native brook trout streams. USGS and West Virginia University scientists are using spatial modeling approaches to assess the potential cumulative effects of unconventional oil and gas (UOG) development on high-quality brook trout streams in the Pennsylvania portion of the basin, which has experienced relatively recent, rapid increase in development. Vulnerability models were developed that incorporate all stages of the UOG development process - infrastructure, drilling, spills, and water withdrawals - that may affect fish and other aquatic resources. These models incorporate measures of aquatic health and status to identify streams that are vulnerable to UOG development. This vulnerability framework can be applied to a variety of ecosystems or energy development scenarios.

\section{Contact}

Kelly O. Maloney, USGS Leetown Science Center, kmaloney@usgs.gov, (304) 724-4579

\section{Publications}

Entrekin, S.A., Maloney, K.O., Kapo, K.E., Walters, A.W., Evans-White, M.A., and Klemow. K.M., 2015, Stream vulnerability to widespread and emergent stressors-A focus on unconventional oil and gas: PLOS ONE, v. 10, no. 9, e0137416, 28 p., https://doi.org/10.1371/journal.pone.0137416.

Maloney, K.O., Baruch-Mordo, S., Patterson, L.A., Nicot, J.-P., Entrekin, S.A., Fargione, J.E., Kiesecker, J.M., Konschnik, K.E., Ryan, J.N., Trainor, A.M., Saiers, J.E., and Wiseman, H.J., 2017, Unconventional oil and gas spills-Materials, volumes and risks to surface waters in four States of the U.S.: Science of the Total Environment, v. 581-582, p. 369-377, https://doi.org/10.1016/j.scitotenv.2016.12.142.

Maloney, K.O., Young, J.A., Faulkner, S.P., Hailegiorgis, A., Slonecker, E.T., and Milheim, L.E., 2018, A detailed risk assessment of shale gas development on headwater streams in the Pennsylvania portion of the Upper Susquehanna River Basin, U.S.A.: Science of the Total Environment, v. 610-611, p. 154-166, https://doi.org/10.1016/j.scitotenv.2017.07.247.

Merriam, E.R., Petty, J.T., Maloney, K.O., Young. J.A., Faulkner, S.P., Slonecker, E.T., Milheim, L.E., Hailegiorgis, A., and Niles J., 2018, Brook trout distributional response to unconventional oil and gas development_Landscape context matters: Science of the Total Environment, v. 628-629, p. 338-349, https://doi.org/10.1016/j.scitotenv.2018.02.062.

Patterson, L.A., Konschnik, K.E., Wiseman, H., Fargione, J., Maloney, K.O., Kiesecker, J., Nicot, J.-P., Baruch-Mordo, S., Entrekin, S., Trainor, A., Ryan, J.N., and Saiers, J.E., 2017, Unconventional oil and gas spills-Risks, mitigation priorities and State reporting requirements: Environmental Science and Technology, v. 51, no. 5, p. 2563-2573, https://doi.org/10.1021/acs.est.6b05749. 


\section{Conservation and Energy Development Planning and Management Tools}

Due to expanding conventional and renewable energy development, decisions regarding siting and permitting of new energygeneration infrastructure are a significant priority for land and resource managers. In support of Federal and State resource management agencies, USGS scientists produce scientific information and project- and landscape-scale tools that can assist resource managers and energy companies in the design and siting of new energy projects to avoid or minimize conflict with fish and wildlife and the critical habitats they depend on. Products include data, models, and tools that can assist managers in prioritizing lands as part of the planning process and for adaptive management at existing energy-generation facilities. Studies focusing on risk assessment help managers evaluate and predict risk to species of conservation concern prior to project design and construction. To better understand effects on vulnerable and rare species, USGS biostatisticians continue to improve statistical tools for more accurate and cost-effective wildlife mortality estimation. Finally, to enhance recovery of degraded terrestrial and aquatic landscapes, USGS scientists are investigating how local and regional practices and conditions influence restoration success, and they are testing novel techniques to improve restoration and recovery of ecosystems.

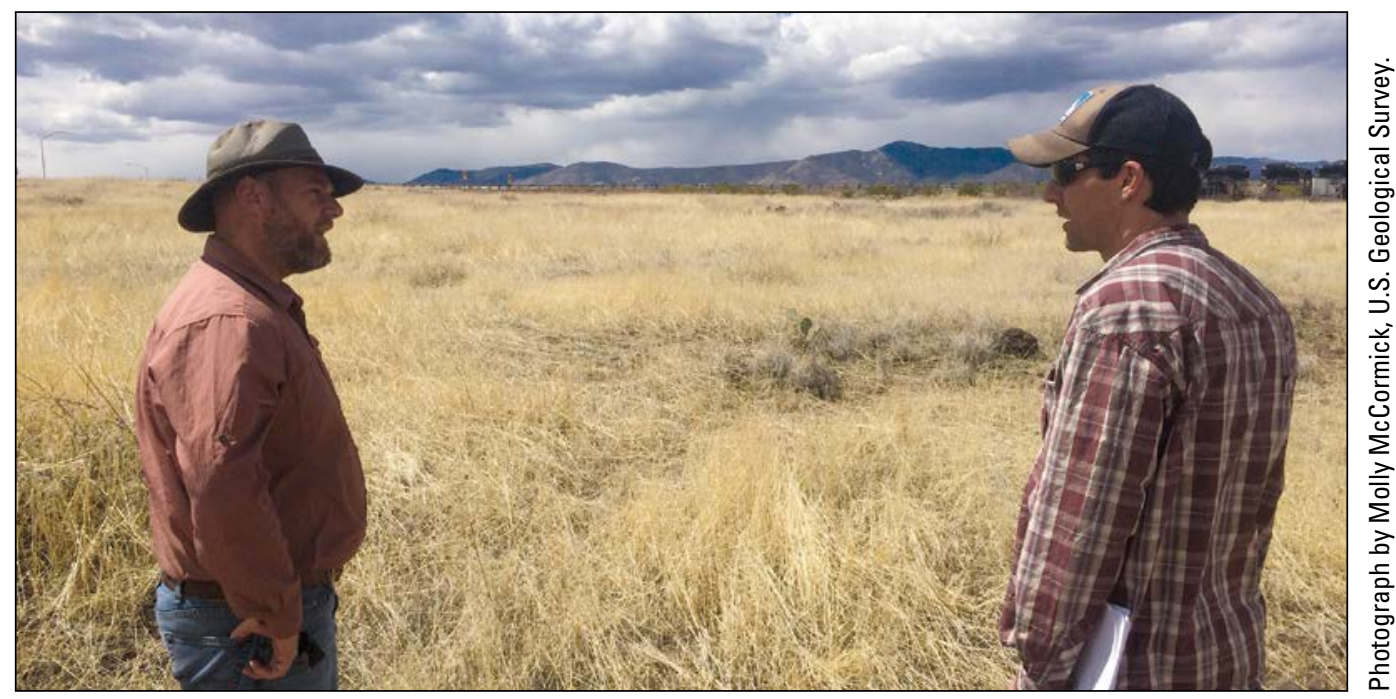

Staff from the Bureau of Land Management and the U.S. Geological Survey discuss land management and restoration practices to mitigate risks posed by invasive species.

\section{Planning and Management Support Tools}
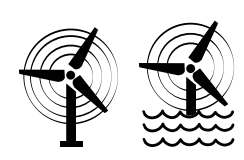

\section{The U.S. Wind Turbine Database}

(AWEA), performs quarterly updates of a national dataset of industry-scale, land-based and offshore wind energy turbines in the United States. The U.S. Wind Turbine Database (https:/eerscmap.usgs.gov/uswtdb/) is an interactive web-based tool that provides technical specifications, such as turbine height, blade length, rotor, power generation capacity, and year of construction, for most turbines. Turbine locations were obtained from multiple sources and are digitized and spatially verified. This national map of wind turbines assists regulatory agencies, NGOs, and other decision makers in planning and management activities.

\section{Contact}

Jay Diffendorfer, USGS Geosciences and Environmental Change Science Center, jediffendorfer@usgs.gov, (303) 236-5369

\section{Publication}

Hoen, B.D., Diffendorfer, J.E., Rand, J.T., Kramer, L.A., Garrity, C.P., and Hunt, H.E., 2019, United States Wind Turbine Database [USWTDB]: U.S. Geological Survey, American Wind Energy Association, and Lawrence Berkeley National

Laboratory data release, USWTDB v. 2.1, July 15, https://eerscmap.usgs.gov/uswtdb. 


\section{Tools for Identifying and Prioritizing Areas Used by Migrating Whooping Cranes}

Whooping cranes of the Aransas-Wood Buffalo population migrate twice each year through the Great Plains between Canada and Texas. To assist with identifying migration areas across this endangered species' migration range and help with recovery efforts of this population, the USGS and partners delineated a migration corridor that identifies areas used by most cranes during their migrations. In partnership with the USFWS, USGS scientists also created a tool that predicts wetland and other landscape features cranes would most likely use during future migrations. These tools offer the USFWS and partners ways to identify landscapes that may be of conservation and management importance to migrating whooping cranes.

\section{Contact}

Aaron Pearse, USGS Northern Prairie

Wildlife Research Center, apearse@usgs.gov, (701) 253-5509

\section{Publications}

Baasch, D.M., Farrell, P.D., Howlin, S., Pearse, A.T., Farnsworth, J.M., and Smith, C.B., 2019, Whooping crane use of riverine stopover sites: PLOS One, v. 14, e0209612, 20 p., https://doi.org/10.1371/journal.pone.0209612.

Baasch, D.M., Farrell, P.D., Pearse, A.T., Brandt, D.A., Caven, A.J., Harner, M.J., Wright, G.D., and Metzger, K.L., 2019, Diurnal habitat selection of migrating whooping crane in the Great Plains: Avian Conservation and Ecology, v. 14, no. 1, article no. 6, 14 p., https://doi.org/10.5751/ACE-01317-140106.

Niemuth, N.D., Ryba, A.J., Pearse, A.T., Kvas, S.M., Brandt, D.A., Wangler, B., Austin, J.E., and Carlisle, M.J., 2018, Opportunistically collected data reveal habitat selection by migrating whooping cranes in the U.S. Northern Plains: The Condor, v. 120 , no. 2, p. 343-356, https://doi.org/10.1650/CONDOR-17-80.1.

Pearse, A.T., Brandt, D.A., Harrell, W.C., Metzger, K.L., Baasch, D.M., and Hefley, T.J., 2015, Whooping crane stopover site use intensity within the Great Plains: U.S. Geological Survey Open-File Report 2015-1166, 12 p., https://doi.org/10.3133/ofr20151166.

Pearse, A.T., Brandt, D.A., Hartup, B.K., and Bidwell, M.T., 2018, Mortality in AransasWood Buffalo whooping cranes-Timing,
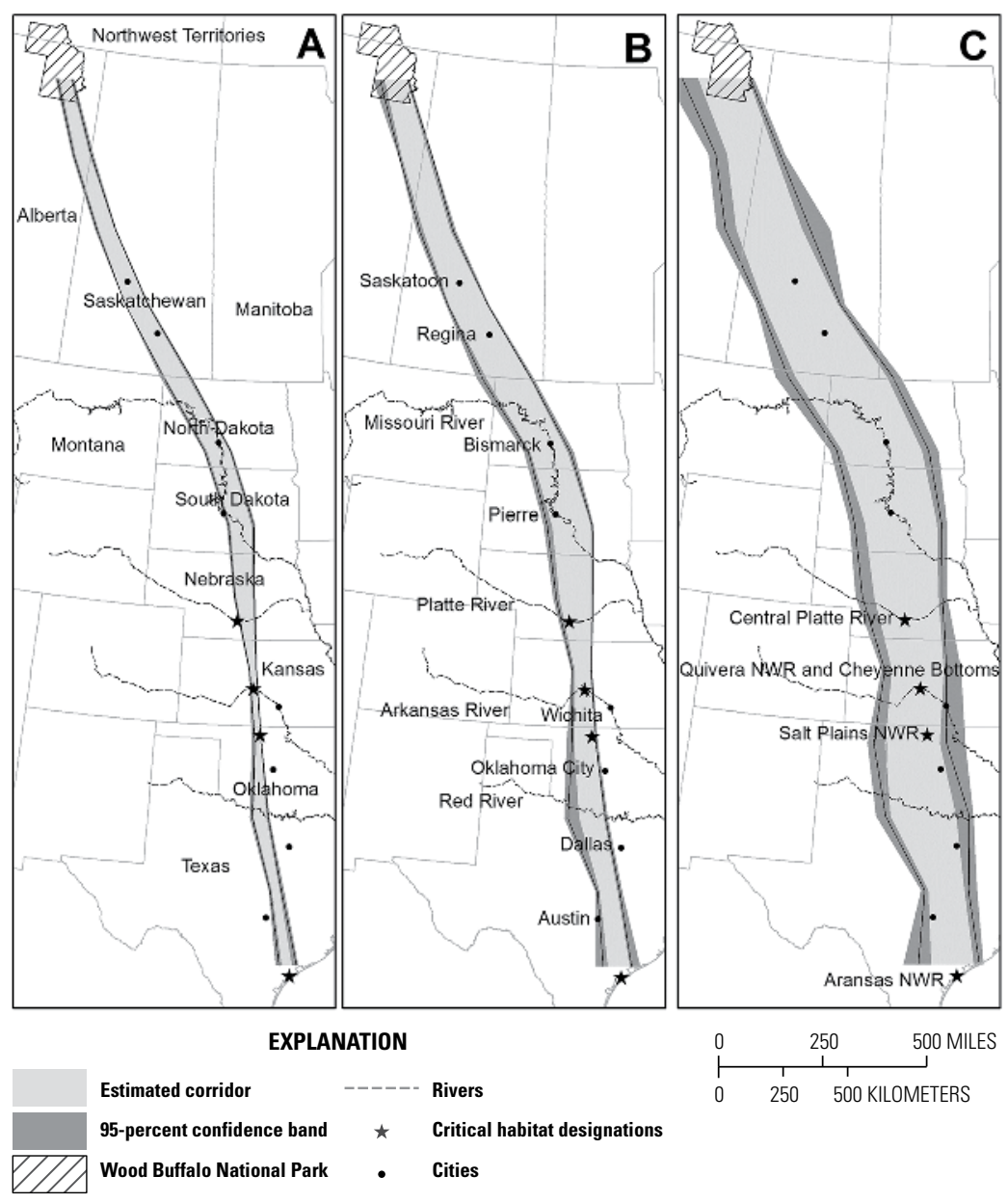

Migration corridors for whooping cranes of the Aransas-Wood Buffalo population, delineating $(A)$ 50-percent core, $(B) 75$ percent core, and (C) 95-percent core migration areas, with 95-percent confidence bands (from Pearse, Rabbe, Juliusson, and others, 2018). location, and causes, chap. 6 of Nyhus, P.J., French, J.B., Jr., Converse, S.J., and Austin, J.E., eds., Whooping cranes-Biology and conservation: San Diego, Calif., Academic Press; Biodiversity of the world - Conservation from genes to landscapes, p. 125-138, https://doi.org/10.1016/ B978-0-12-803555-9.00006-2.

Pearse, A.T., Rabbe, M., Bidwell, M.T., Juliusson, L.M., Craig-Moore, L., Brandt, D.A., and Harrell, W., 2018, Map of whooping crane migration corridors: U.S. Geological Survey data release, https://doi.org/10.5066/F7FT8K74.

Pearse, A.T., Rabbe, M., Juliusson, L.M., Bidwell, M.T., Craig-Moore, L., Brandt, D.A., and Harrell, W., 2018, Delineating and identifying long-term changes in the whooping crane (G rus americana) migration corridor: PLOS ONE v. 13, no. 2 , e0192737, 15 p., https://doi.org/10.1371/journal.pone.0192737. 


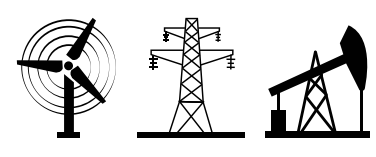

\section{Mapping Probable Suitable Habitat for Rare Plants in California Deserts}

with plant and wildlife conservation in California deserts. To support the BLM in planning efforts and conservation of habitat for multiple rare plants, the USGS evaluated existing data and habitat models and developed a process for mapping probable suitable habitat for 26 plant species and potential suitable habitat for 41 plant species. Lands prioritized for renewable energy development contained 3 percent of the habitat modeled as suitable for at least one species. These products can be used by agencies to review proposed projects and plan future plant surveys and by developers to target sites likely to minimize conflicts with rare plant conservation goals.

\section{Contact}

Sarah K. Carter,

USGS Fort Collins Science

Center, skcarter@usgs.gov, (970) 226-9355

\section{Publication}

Reese, G.C., Carter, S.K., Lund, C., and Walterscheid, S., 2019, Evaluating and using existing models to map probable suitable habitat for rare plants to inform management of multiple-use public lands in the California desert: PLOS ONE, v. 14, no. 4, e0214099, 26 p., https://doi.org/10.1371/ journal.pone.0214099.

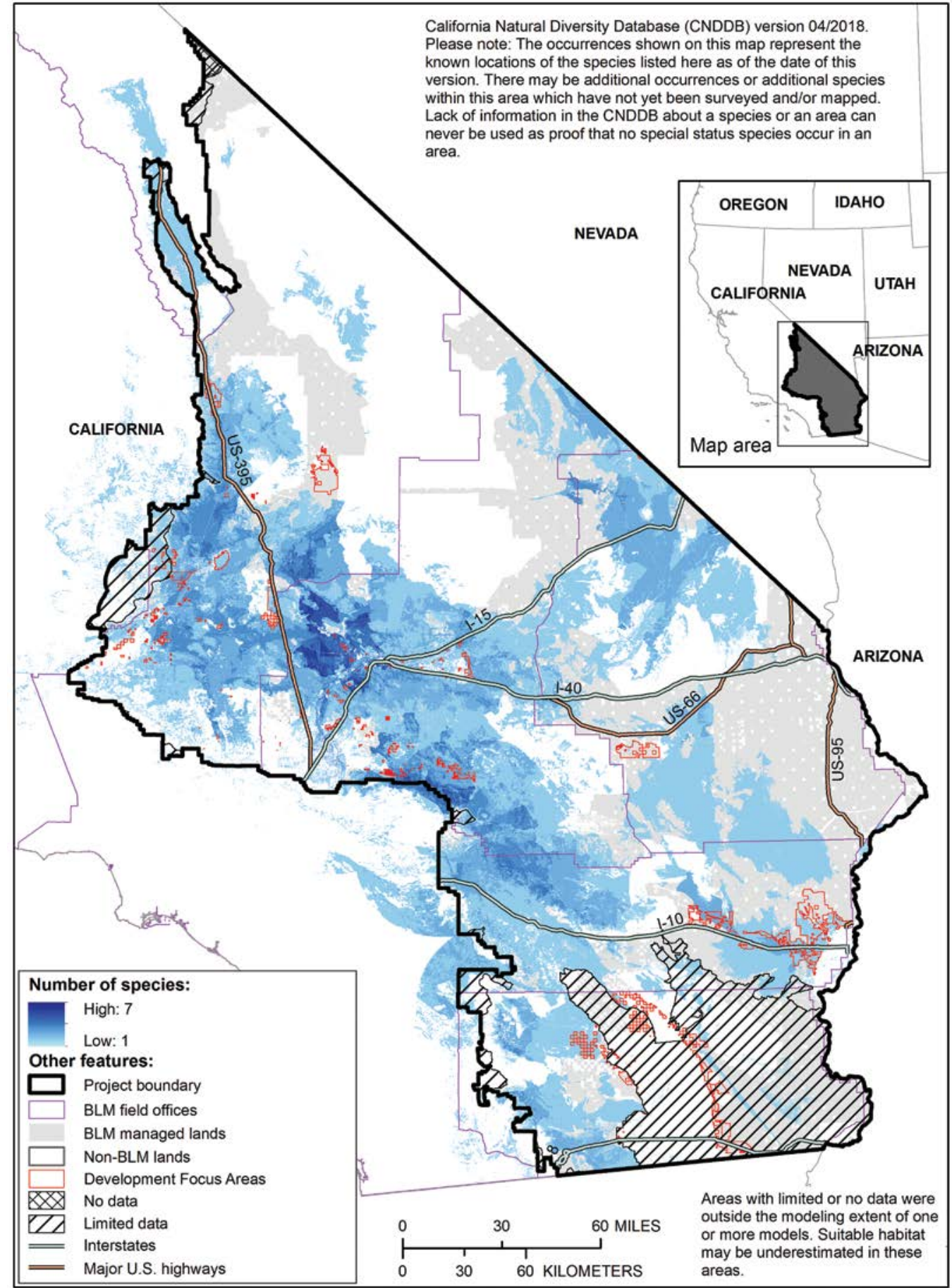

Multispecies map of probable suitable habitat. Shades of blue indicate the number of species for which probable suitable habitat is predicted. Image from Reese and others (2019), Creative Commons CCO. 


\section{Smart Energy Development in the Sagebrush Ecosystem}

1 The USGS is developing science and decision support tools to inform policy and management decisions about various aspects of the energy development life cycle. These tools are particularly important given ongoing demands for limited natural resources and the need to be cost effective and to make decisions at the broader landscape scale. USGS scientists are working with Federal, State, and industry partners to develop the natural resource knowledge, management tools, risk assessments, and scenario planning that will form the scientific foundation for managers to target areas of high resource potential and low environmental concern and inform effective development.

\section{Contact}

Steven Hanser, USGS Fort Collins Science Center; shanser@usgs.gov; (970) 226-9309

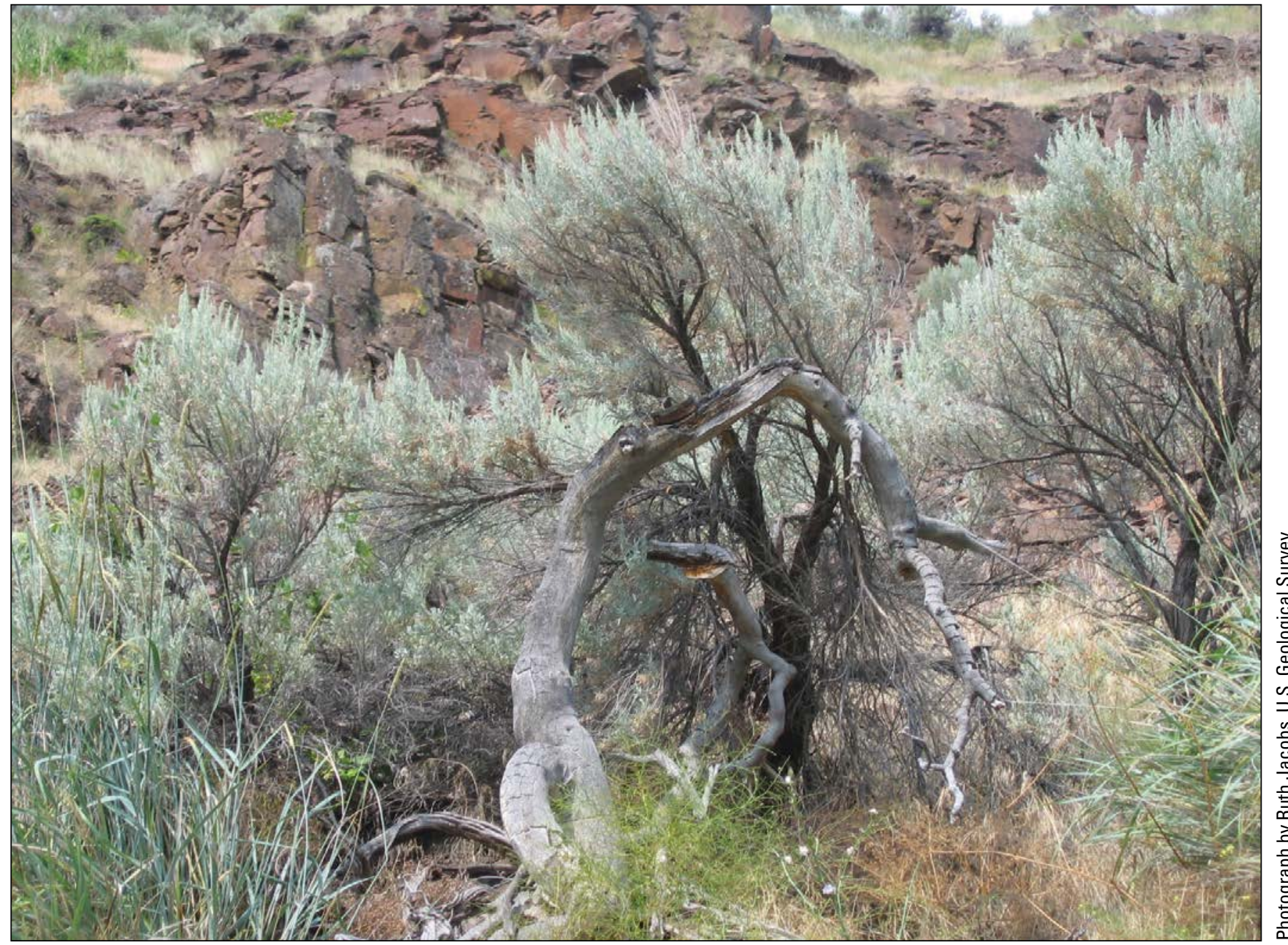

Sagebrush grasslands. 


\section{Effects of Nest Exposure and Spring Temperatures on Eagle Nestling Survival}

Golden eagle populations are affected by anthropogenic mortality through shooting, electrocution, poisoning, vehicle strikes, and collision with wind turbines (Millsap and others, 2016), and available tools for mitigating mortality from anthropogenic causes are currently limited to retrofitting power lines, which can reduce electrocutions. To provide the USFWS with additional tools that may mitigate mortality, the USGS tested the effectiveness of artificial shade structures as a method to increase productivity at golden eagle nest sites in the Western United States. USGS, Owyhee Desert Studies, and University of Nevada scientists analyzed 43 years of golden eagle nestling survival data in relation to spring temperatures and nest exposure to the afternoon sun. They predicted that nestling survival in nests exposed to the afternoon sun would be lower than those that were shaded, particularly when there were several hot days during nesting. The study found that golden eagle nestlings reared in nests outfitted with artificial shade structures were more likely to reach fledgling age, supporting the prediction that shaded nests reduce heat-related mortality of nestling golden eagles.

\section{Contact}

Martin Fitzpatrick, USGS Forest and Rangeland Ecosystem Science Center, mfitzpatrick@usgs.gov, (541) 750-1032

\section{Publication}

Kochert, M.N., Steenhof, K., and Brown, J.L., 2019, Effects of nest exposure and spring temperatures on golden eagle brood survival—An opportunity for mitigation: Journal of Raptor Research, v. 53, no. 1, p. 91-97, https://doi.org/10.3356/ JRR-17-100.

\section{Additional Publications}

Dilts, T.E., Weisberg, P.J., Leitner, P., Matocq, M.D., Inman, R.D., Nussear, K.E., and Esque, T.C., 2016, Multiscale connectivity and graph theory highlight critical areas for conservation under climate change: Ecological Applications, v. 26, no. 4, p. 1223-1237, https://doi.org/10.1890/15-0925.

Hoelting, K., and Burkardt, N., 2017, Human dimensions of climate change in coastal Oregon: Washington, D.C., U.S. Department of the Interior, Bureau of Ocean Energy Management, [BOEM], OCS Study BOEM 2017-052, prepared under BOEM Intra-Agency Agreement no. M15PG00008, 216 p., https://www.boem.gov/ESPIS/5/5630.pdf.

Inman, R.D., Esque, T.C., Nussear, K.E., Leitner, P., Matocq, M.D., Weisberg, P.J., and Dilts, T.E., 2016, Impacts of climate change and renewable energy development on habitat of an endemic squirrel, Xerospermophilus mohavensis, in the Mojave Desert, U.S.A.: Biological Conservation, v. 200, p. 112-121, https://doi.org/10.1016/j.biocon.2016.05.033.

Kreitler, J., Schloss, C.A., Soong, O., Hannah, L., and Davis, F.W., 2015, Conservation planning for offsetting the impacts of development-A case study of biodiversity and renewable energy in the Mojave Desert: PLOS ONE, v. 10, no. 11, e0140226, 15 p., https://doi.org/10.1371/journal.pone.0140226.

Moore-O’Leary, K.A., Hernandez, R.R., Johnston, D.S., Abella, S.R., Tanner, K.E., Swanson, A.C., Kreitler, J., and Lovich, J.E., 2017, Sustainability of utility-scale solar energy - Critical ecological concepts: Frontiers in Ecology and the Environment, v. 15, no. 7, p. 385-394, https://doi.org/10.1002/fee.1517.

Nowicki, S.A., Inman, R.D., Esque, T.C., Nussear, K.E., and Edwards, C.S., 2019, Spatially consistent high-resolution land surface temperature mosaics for thermophysical mapping of the Mojave Desert: Sensors, v. 19, no. 12, article no. 2669, 17 p., https://doi.org/10.3390/s19122669.

Thomas, K.A., Jarchow, C.J., Arundel, T.R., Jamwal, P., Borens, A., and Drost., C.A., 2018, Landscape-scale wildlife species richness metrics to inform wind and solar energy facility siting-An Arizona case study: Energy Policy, v. 116, p. 145-152, https://doi.org/10.1016/j.enpol.2018.01.052. 


\section{Risk Assessment Tools and Management Strategies}

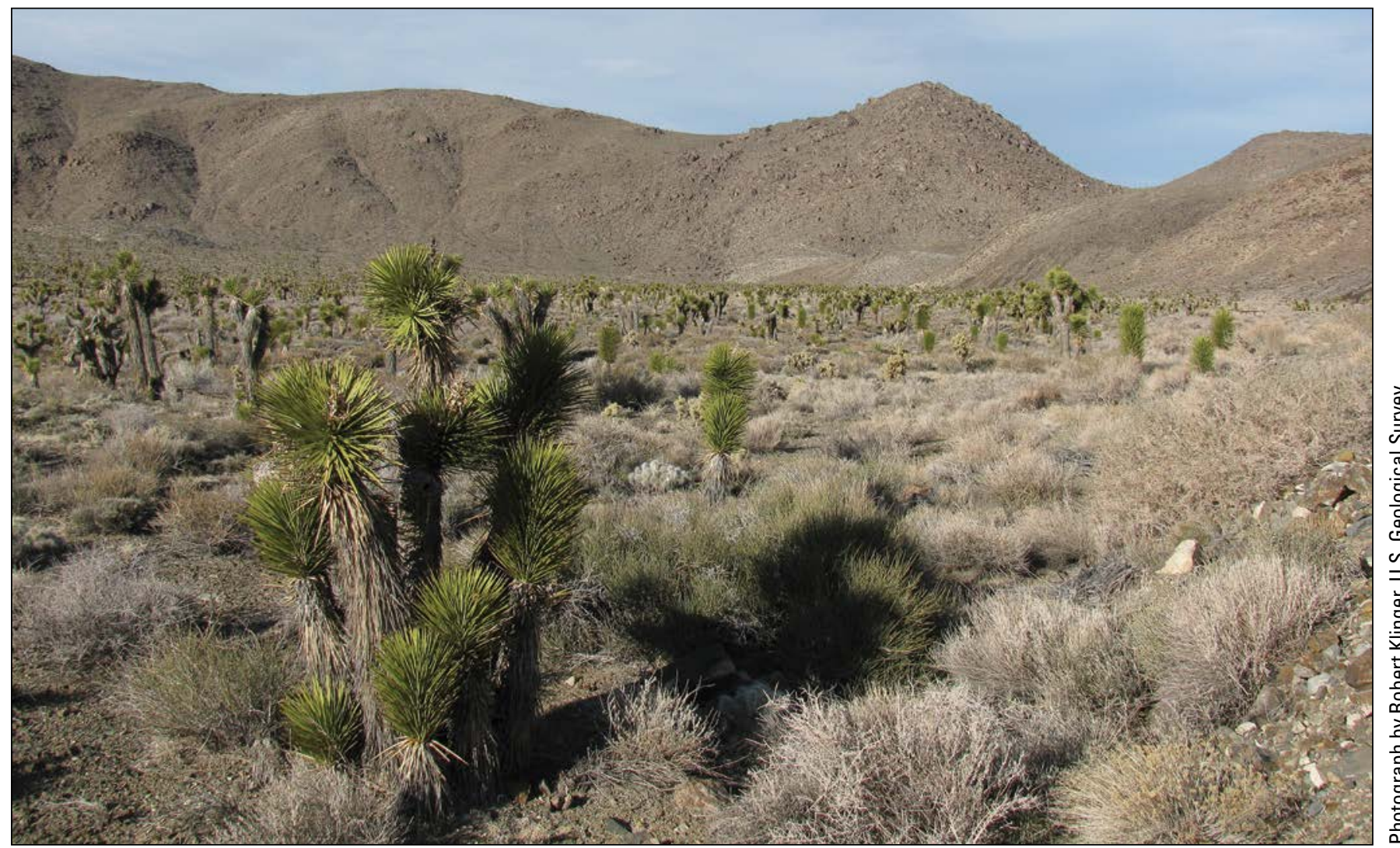

Plant community in the Mojave Desert.

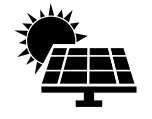

\section{Factors Influencing Bird Mortality at Utility-Scale Solar Facilities in California}

power is advancing rapidly in the United States and around the world, but a number of solar facilities in California are linked to varying levels of bird mortality in ways that are poorly understood. The USGS is leading a multipartner project funded by the California Energy Commission and the solar energy industry to examine behavioral, anthropogenic, and landscape factors that may be responsible for bird mortality at solar facilities in the arid Southwest. Ultimately, the research seeks to reduce bird mortality while limiting the impacts on alternative energy generation by (1) identifying potentially viable approaches for deterring birds from approaching solar facilities and (2) informing future siting decisions in ways that reduce the likelihood of birds encountering solar facilities.

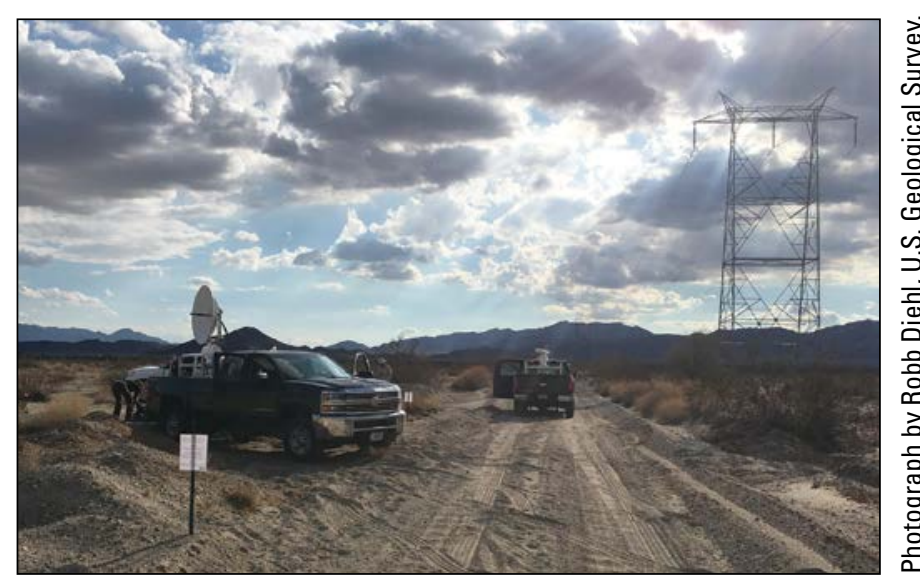

Portable radar near the Desert Sunlight solar energy facility in California.

\section{Contact}

Robb Diehl, USGS Northern Rocky Mountain Science Center, rhdiehl@usgs.gov, (406) 994-7481

\section{Publication}

Diehl, R.H., Valdez, E.W., Preston, T.M., Wellik, M.J., Cryan, P.M., and Mousseau, T.A., 2016, Evaluating the effectiveness of wildlife detection and observation technologies at a solar power tower facility: PLOS ONE, v. 11, no. 7, e0158115, 29 p., https://doi.org/10.1371/journal.pone.0158115. 


\section{Assessing Eagle Use Frequency at Wind Energy Facilities}

Operation of wind energy facilities can adversely affect eagles, among other wildlife. USFWS guidelines suggest wind facility operators or developers survey eagle use and calculate the risk to eagles across the project area; however, questions have arisen concerning the degree to which data from survey plots represent eagle use over an entire project area. The USGS is using existing telemetry data on golden eagles in the Mojave Desert, California, to help the USFWS compare eagle use within a plot to eagle use over an entire project area. Results can provide a better understanding of golden eagle activity and a context for interpreting survey data collected at potential wind energy facilities.

\section{Contact}

Todd E. Katzner, USGS Forest and Rangeland Ecosystem Science Center, tkatzner@usgs.gov, (208) 426-5232

\section{Publication}

Sur, M., Belthoff, J.R., Bjerre, E.R., Millsap, B.A., and Katzner, T., 2018, The utility of point count surveys to predict wildlife interactions with wind energy facilities-An example focused on golden eagles: Ecological Indicators, v. 88, p. 126-133, https://doi.org/10.1016/j.ecolind.2018.01.024.

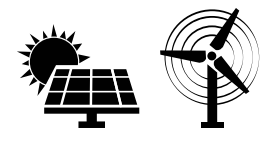

\section{Tools to Assess Energy Development Impacts on Sensitive Birds and Bats} populations of sensitive bird and bat species in California. As part of this project, stable isotopes are being used to estimate the geographic scope of the population of birds or bats affected, and demographic modeling is being used to forecast how individual fatalities affect the growth or decline of the species' populations. Development of analytical methods can aid in determining the best practices for conducting risk assessments and predicting mitigation outcomes. Field survey design and protocols are also being developed and integrated with the developed tools. These tools can allow energy developers to more accurately estimate fatality rates and effects of mitigation techniques at wind and solar energy facilities, which may streamline permitting and ultimately reduce costs of energy development.

\section{Contacts}

Manuela M. Huso, USGS Forest and Rangeland Ecosystem Science Center, mhuso@usgs.gov, (541) 750-0948

Todd E. Katzner, USGS Forest and Rangeland Ecosystem Science Center, tkatzner@usgs.gov, (208) 426-5232

\section{Publications}

Katzner, T.E., Nelson, D.M., Braham, M.A., Doyle, J.M., Fernandez, N.B., Duerr, A.E., Bloom, P.H., Fitzpatrick, M.C., Miller, T.A., Culver, R.C.E., Braswell, L., and DeWoody, J.A., 2017, Golden eagle fatalities and the continental-scale consequences of local wind-energy generation: Conservation Biology, v. 31, no. 2, p. 406-415, https://doi.org/10.1111/cobi.12836.

Vander Zanden, H.B., Nelson, D.M., Wunder, M.B., Conkling, T.J., and Katzner, T., 2018, Application of isoscapes to determine geographic origin of terrestrial wildlife for conservation and management: Biological Conservation, v. 228, p. 268-280, https://doi.org/10.1016/j.biocon.2018.10.019.

Vander Zanden, H.B., Reid, A., Katzner, T., and Nelson, D.M., 2018, Effect of heat and singeing on stable hydrogen isotope ratios of bird feathers and implications for their use in determining geographic origin: Rapid Communications in Mass Spectrometry, v. 32, no. 21, p. 1859-1866, https://doi.org/10.1002/rcm.8253.

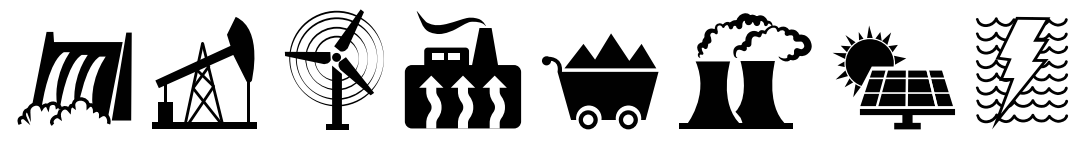

\section{Quantifying the Potential Effects of Energy Development on Wildlife and Ecosystem Services}

Energy resources are critical for a prosperous and secure Nation, and a clear understanding of the potential effects of energy resource development is necessary for efficient and minimally impactful energy extraction and production activities. USGS scientists are developing approaches to compare impacts across energy types and applying probabilistic models to evaluate the potential effects of energy development on landscapes, wildlife, and ecosystem services, building from the geology-based 
USGS assessments of undiscovered petroleum resources. Ongoing projects are using the energySim model to understand potential surface disturbance changes in sediment erosion associated with energy development and the energy footprint model (https://www.sciencebase.gov/catalog/item/589e441ae4b099f50d3a0e6b) to evaluate the effects of greater sage-grouse core area policy on shaping landscape patterns and wildlife habitat quality.

\section{Contacts}

Monica Dorning, USGS Geosciences and Environmental Change Science Center, mdorning@usgs.gov, (352) 264-3499

Jay Diffendorfer, USGS Geosciences and Environmental Change Science Center, jediffendorfer@usgs.gov, (303) 236-5369

\section{Publications}

Dorning, M., Diffendorfer, J.E., Loss, S.R., and Bagstad, K.J., 2019, Review of indicators for comparing environmental effects across energy sources: Environmental Research Letters, accepted manuscript posted August 31, 2019, 28 p., https://doi.org/10.1088/1748-9326/ab402d.

Garman, S.L., 2018, A simulation framework for assessing physical and wildlife impacts of oil and gas development scenarios in southwestern Wyoming: Environmental Modeling and Assessment, v. 23, no. 1, p. 39-56, https://doi.org/10.1007/s10666-0179559-1.

Loss, S.R., Dorning, M.A., and Diffendorfer, J.E., 2019, Biases in the literature on direct wildlife mortality from energy development: BioScience, v. 69, no. 5, p. 348-359, https://doi.org/10.1093/biosci/biz026.

Martinez, C., 2017, energySim—An R package: U.S. Geological Survey software release, https://doi.org/10.5066/f7x34vzf.

\section{Evaluating Population-Level Impacts of Wind Energy Development}

The impact of wind energy generation on wildlife is commonly approached by monitoring the incidence of mortality resulting from turbine collisions. These mortality events may or may not scale up to observable impacts at a population level. USGS scientists are developing and implementing approaches for assessing population-level impacts of wind energy on birds and bats. This research can assist conservation managers with wind energy project permitting and the use and interpretation of monitoring protocols for wind facilities.

\section{Contacts}

Jay Diffendorfer, USGS Geosciences and Environmental Change Science Center, jediffendorfer@usgs.gov, (303) 236-5369 Wayne E. Thogmartin, USGS Upper Midwest Environmental Science Center, wthogmartin@usgs.gov, (608) 781-6309

\section{Publications}

Beston, J.A., Diffendorfer, J.E., Loss, S.R., and Johnson, D.H., 2016, Prioritizing avian species for their risk of population-level consequences from wind energy development: PLOS ONE, v. 11, no. 3, e0150813, 19 p., https://doi.org/10.1371/journal. pone. 0150813 .

Diffendorfer, J.E., Beston, J.A., Merrill, M.D., Stanton, J.C., Corum, M.D., Loss, S.R., Thogmartin, W.E., Johnson, D.H., Erickson, R.A., and Heist, K.W., 2017, A method to assess the population-level consequences of wind energy facilities on bird and bat species, in Köppel, J., ed., Wind energy and wildlife interactions-Presentations from the CWW2015 Conference: Cham, Switzerland, Springer, p. 65-76, https://doi.org/10.1007/978-3-319-51272-3_4.

Diffendorfer, J.E., Beston, J.A., Merrill, M.D., Stanton, J.C., Corum, M.D., Loss, S.R., Thogmartin, W.E., Johnson, D.H., Erickson, R.A., and Heist, K.W., 2019, A methodology to assess the national and regional impacts of U.S. wind energy development on birds and bats: U.S. Geological Survey Scientific Investigations Report 2018-5157, 45 p., https://doi.org/10.3133/sir20185157.

Erickson, R.A., Thogmartin, W.E., Diffendorfer, J.E., Russell, R.E., and Szymanski, J.A., 2016, Effects of wind energy generation and white-nose syndrome on the viability of the Indiana bat: PeerJ, v. 4, e2830, https://doi.org/10.7717/peerj.2830.

Haider, H.S., Oldfield, S.C., Tu, T., Moreno, R.K., Diffendorfer, J.E., Eager, E.A., and Erickson, R.A., 2017, Incorporating allee effects into the potential biological removal level: Natural Resource Modeling, v. 30, no. 3, e12133, 16 p., https://doi.org/10.1111/nrm.12133.

Thompson, M., Beston, J.A., Etterson, M., Diffendorfer, J.E., and Loss, S.R., 2017, Factors affecting bat mortality rates at wind energy facilities in the United States: Conservation Biology, v. 215, p. 241-245, https://doi.org/10.1016/j.biocon.2017.09.014. 


\section{Structured Decision Making: Decision Support Frameworks and Tools for
Conservation}

Structured decision making (SDM) is an approach for careful and organized analysis of natural resource management decisions. SDM encompasses a set of concepts and steps based on decision theory and risk analysis, including making decisions on the basis of clearly articulated fundamental objectives, recognizing the role of scientific predictions in decisions, dealing explicitly with uncertainty, and responding transparently to societal values in decision making. This approach can be used to address a variety of resource management decisions related to the operation and management of energy infrastructure, including the long-term management of the Glen Canyon Dam in northern Arizona.

\section{Contact}

Michael Runge, USGS Patuxent Wildlife Research Center, mrunge@usgs.gov, (301) 497-5748

\section{Publications}

Cummings, J.W., Converse, S.J., Smith, D.R., Morey, S., and Runge, M.C., 2018, Implicit decision framing as an unrecognized source of confusion in endangered species classification: Conservation Biology, v. 32, no. 6, p. 1246-1254, https://doi.org/10.1111/cobi.13185.

Runge, M.C., and McDonald-Madden, E., 2018, Helping decision makers frame, analyze, and implement decisions: Decision Point Online, no. 104, p. 12-15, http://decision-point.com.au/article/navigating-the-field-of-decision-analysis/.

Schwartz, M.W., Cook, C.N., Pressey, R.L., Pullin, A.S., Runge, M.C., Salafsky, N., Sutherland, W.J., and Williamson, M.A., 2018, Decision support frameworks and tools for conservation: Conservation Letters, v. 11, no. 2, e12385, 19 p., https://doi.org/10.1111/conl.12385.

\section{Additional Publications}

Katzner, T., Bennett, V., Miller, T., Duerr, A., Braham, M., and Hale, A., 2016, Wind energy development-Methods for assessing risks to birds and bats pre-construction: Human-Wildlife Interactions, v. 10, no. 1, p. 42-52, http://digitalcommons.usu.edu/hwi/vol10/iss 1/6/.

Watson, R.T., Kolar, P.S., Ferrer, M., Nygård, T., Johnston, N., Hunt, W.G., Smit-Robinson, H.A., Farmer, C.J., Huso, M., and Katzner, T., 2018, Raptor interactions with wind energy — Case studies from around the world: Journal of Raptor Research, v. 52, no. 1, p. 1-18, https://doi.org/10.3356/JRR-16-100.1.

\section{Novel Techniques in Species Detection and Monitoring for Energy Planning and Conservation}

\section{Reducing Bird and Bat Wind Turbine Strikes Using Weather Radar}

Many remote sensing methods designed to guide wind turbine curtailment in the presence of birds and bats (for example, cameras and portable radar) represent widespread deployment of new sensor networks that may add considerable complexity and cost to wind energy operators in the United States. The most feasible solutions to minimizing wind energy impacts on birds and bats typically are easy to deploy, inexpensive to operate, and highly reliable, and they require little maintenance and minimize energy generation losses. USGS scientists are collaborating with the National Renewable Energy Laboratory through a DOE-funded Technology Development and Innovation project on a two-pronged study consisting of a localized field component and a national-level assessment to determine whether the Next Generation Weather Radar (NEXRAD) system can accurately monitor bird and bat movements at wind facilities across much of the continental United States. If this approach is validated, the NEXRAD system could then serve as a low-cost, low-maintenance platform to inform smart curtailment of wind energy operations in the presence of birds and bats.

\section{Contact}

Robb Diehl, USGS Northern Rocky Mountain Science Center, rhdiehl@usgs.gov, (406) 994-7481 


\section{Automated Detection and Classification of Waterfowl, Seabirds, and Other Wildlife on the Outer Continental Shelf}

In collaboration with BOEM, USFWS, and the International Computer Science Institute Vision Group, USGS scientists are developing deep learning algorithms and tools for the automatic detection and classification of waterfowl, seabirds, and other marine wildlife from digital aerial imagery. In addition, USGS scientists are conducting quarterly aerial surveys that can provide baseline information on wildlife distributions, abundance, and movements by season. This information can inform environmental assessments and impact analyses of potential wildlife exposure to offshore energy development projects on the U.S. Atlantic OCS. Automated methods can also be used to improve the safety, efficiency, and accuracy of migratory bird surveys regularly conducted by the USFWS in the Great Lakes.

\section{Contact}

Jennifer Dieck, USGS Upper Midwest Environmental Sciences Center, jdieck@usgs.gov,

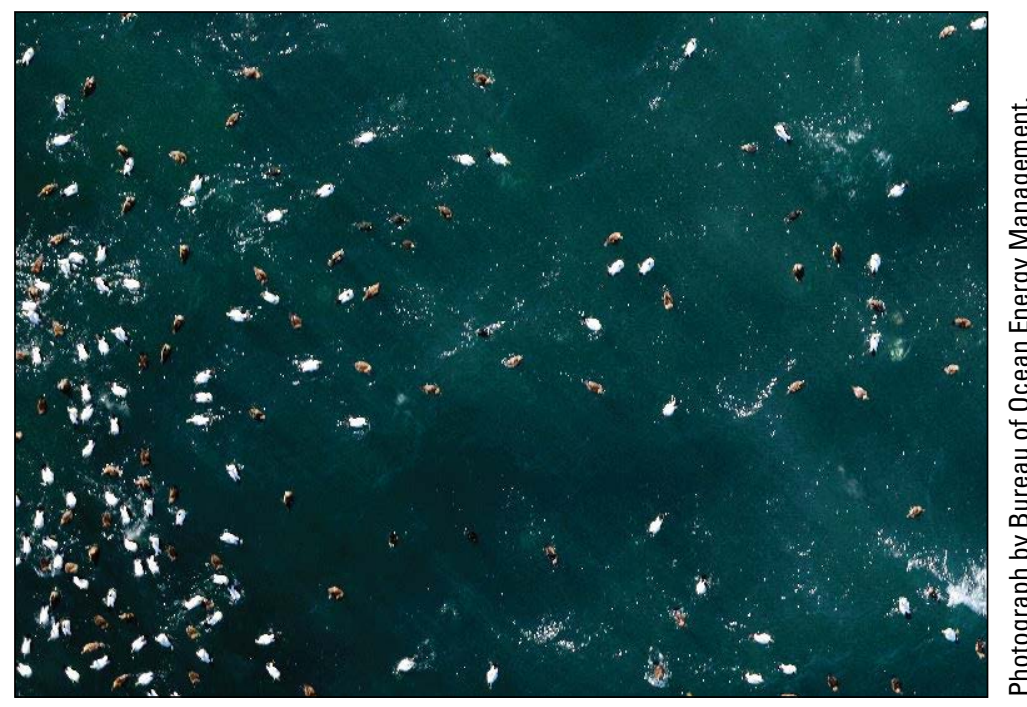

Aerial photograph of a mixed flock of sea ducks, including common eiders and black scoters. (608) 781-6382

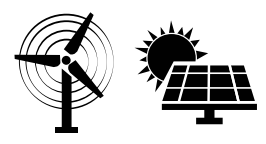

\section{Advancing Wildlife Monitoring Using Weather Surveillance Radar}

USGS research in aeroecology relies on advancing radar and other kinds of remote sensing technology to understand the behavior and ecology of flying animals. Such advances include new methods of quantification and the use of machine learning to improve discrimination of different types of flying animals. The USGS is using both historical data and present-day technologies to observe wildlife behaviors in response to changing habitats and landscapes, such as wind and solar energy development and artificial light, as well as ecological barriers and extreme weather events. This research can help with the development of tools designed to predict risks to flying animals.

\section{Contacts}

Robb Diehl, USGS

Northern Rocky Mountain Science Center, rhdiehl@usgs.gov, (406) 994-7481

Wylie C. Barrow, Jr., USGS Wetland and Aquatic Research Center, barroww@usgs.gov, (337) 266-8668

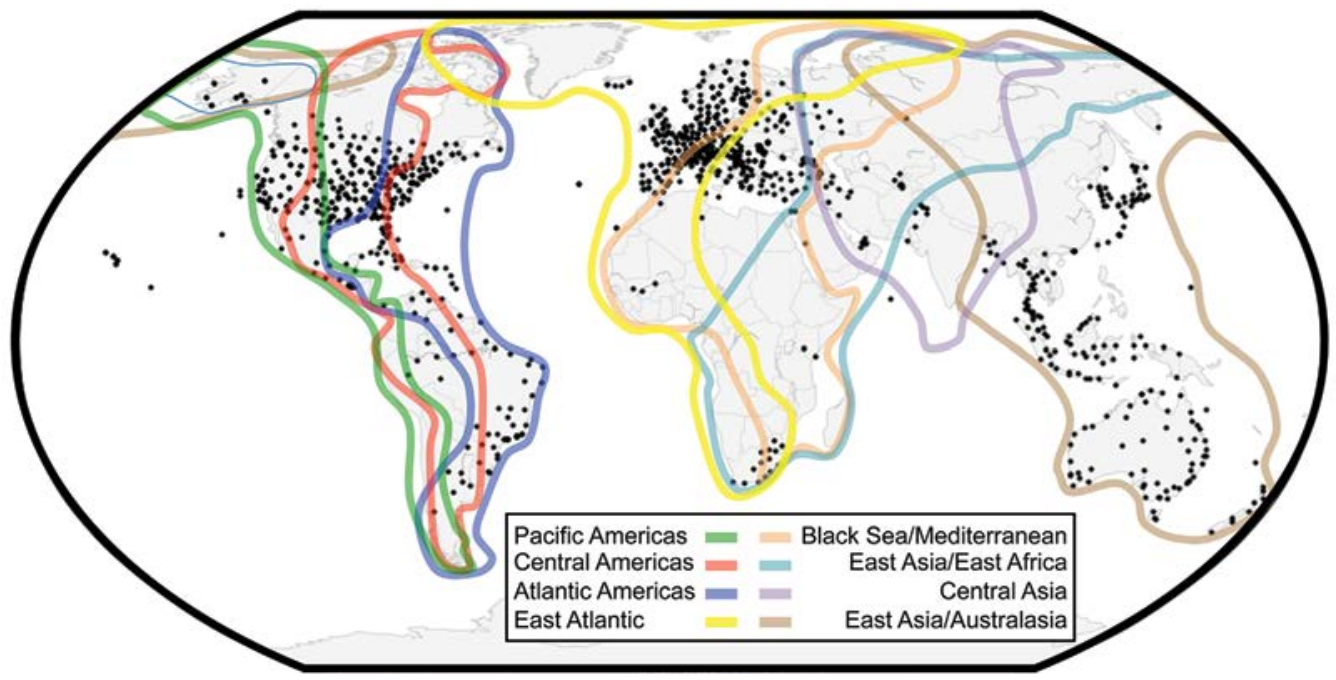

Global overview of weather radar sites registered with the World Meteorological Organization, with the major global flyways superimposed. Flyways were obtained from http://www.birdlife.org/ worldwide/programme-additional-info/migratory-birds-and-flyways. Image from Hüppop and others (2019), Creative Commons 3.0 license. 


\section{Publications}

Buler, J.J., Barrow, W.C., Boone, M.E., Dawson, D.K., Diehl, R.H., Moore, F.R., Randall, L.A., Schreckengost, T.D., and Smolinsky, J.A., 2017, Linking animals aloft with the terrestrial landscape, in Chilson, P.B., Frick, W.F., Kelly, J.F., and Liechti, F., eds., Aeroecology: Cham, Switzerland, Springer, p. 347-378, https://doi.org/10.1007/978-3-319-68576-2_14.

Diehl, R.H., Peterson, A.C., Bolus, R.T., and Johnson, D.H., 2017, Extending the habitat concept to the airspace, in Chilson, P.B., Frick, W.F., Kelly, J.F., and Liechti, F., eds., Aeroecology: Cham, Switzerland, Springer, p. 47-69, https://doi.org/10.1007/978-3-319-68576-2_3.

Hüppop, O., Ciach, M., Diehl, R.H., Reynolds, D.R., Stepanian, P.M., and Menz, M.H.M., 2019, Perspectives and challenges for the use of radar in biological conservation: Ecography, v. 42, no. 5, p. 912-930, https://doi.org/10.1111/ecog.04063.

McLaren, J.D., Buler, J.J., Schreckengost, T., Smolinsky, J.A., Boone, M., van Loon, E.E., Dawson, D.K., Walters, E.L. and Norris, R., 2018, Artificial light at night confounds broad-scale habitat use by migrating birds: Ecology Letters, v. 21, no. 3, p. 356-364, https://doi.org/10.1111/ele.12902.
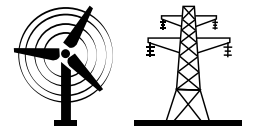

\section{Monitoring Golden Eagle Nests, Prey, and Behavior Using Cameras}

Boise State University and USGS scientists described a less invasive way to monitor golden eagle nests built on steep canyon walls by using motion-activated trail cameras. They found that camera observations recorded twice the number of prey as laboratory examination of prey remains and pellets, were more likely to detect the smallest and largest prey, and cost half as much as laboratory examination. Cameras recorded productivity, fledging dates, and in one case, a nestling death. Trail cameras may be a reliable and cost-effective option to obtain information about eagle behavior and nest contents. In addition, researchers gathered and compiled data on golden eagle diets to summarize and compare prey diversity across the West and desert Southwest and construct predictive models that link prey availability and abundance with eagle productivity and survival. Detailed information about golden eagle prey can help prioritize prey management and develop conservation strategies.

\section{Contacts}

Martin Fitzpatrick, USGS Forest and Rangeland Ecosystem Science Center, mfitzpatrick@usgs.gov, (541) 750-1032 Kathleen Longshore, USGS Western Ecological Research Center, longshore@usgs.gov, (702) 564-4505

\section{Publications}

Bedrosian, G., Watson, J.W., Steenhof, K., Kochert, M.N., Preston, C.R., Woodbridge, B., Williams, G.E., Keller, K.R., and Crandall, R.H., 2017, Spatial and temporal patterns in golden eagle diets in the Western United States, with implications for conservation planning: Journal of Raptor Research, v. 51, no. 3, p. 347-367, https://doi.org/10.3356/JRR-16-38.1.

Harrison, J.T., Kochert, M.N., Pauli, B.P., and Heath, J.A., 2019, Using motion-activated trail cameras to study diet and productivity of cliff-nesting golden eagles: Journal of Raptor Research, v. 53, no. 1, p. 26-37, https://doi.org/10.3356/ JRR-18-26.

Longshore, K.M., Esque, T.C., Nussear, K.E., Johnson, D., Simes, M., and Inman, R.D., 2017, An assessment of food habits, prey availability, and nesting success of golden eagles within the Desert Renewable Energy Conservation Plan Area: California Energy Commission, CEC-500-2017-003, prepared by U.S. Geological Survey under contract no. 500-12-17, 57 p., https://pubs.er.usgs.gov/publication/70190366.

Simes, M.T., Longshore, K.M., Nussear, K.E., Beatty, G.L., Brown, D.E., and Esque, T.C., 2015, Black-tailed and white-tailed jackrabbits in the American West-History, ecology, ecological significance, and survey methods: Western North American Naturalist, v. 75, no. 4, p. 491-519, https://doi.org/10.3398/064.075.0406.

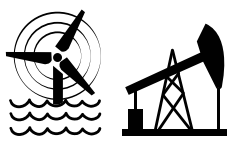

\section{3. eDNA Applications in Freshwater and Ocean Environments}

USGS scientists are developing standards and methodologies for applying molecular and genetic studies, including eDNA, in freshwater and ocean environments. Recent advances include a methodology that improves eDNA yield and quality from water samples. In addition, USGS geneticists used eDNA to estimate occurrence in vulnerable manatee populations and showed that eDNA-derived detection estimates for manatees were higher than those generated by using aerial survey data on the west coast of Florida, indicating that the use of eDNA is effective for population monitoring. Cutting-edge 
genomic resources and techniques can provide resource managers with new ways of monitoring rare and cryptic species, as well as the ability to more easily characterize the biodiversity of remote or poorly studied ecosystems. This information can be used by resource managers to inform energy development decisions in freshwater and ocean environments.

\section{Contacts}

Margaret Hunter, USGS Wetland and Aquatic Research Center, mhunter@usgs.gov, (352) 264-3484

Richard Erickson, USGS Upper Midwest Environmental Sciences Center, rerickson@usgs.gov, (608) 781-6353

Robert S. Cornman, USGS Fort Collins Science Center, rcornman@usgs.gov, (970) 226-9380

Cheryl Morrison, USGS Leetown Science Center, cmorrison@usgs.gov, (304) 724-4464

\section{Publications}

Cornman, R.S., McKenna, J.E., Jr., Fike, J., Oyler-McCance, S.J., and Johnson, R., 2018, An experimental comparison of composite and grab sampling of stream water for metagenetic analysis of environmental DNA: PeerJ, v. 6, e5871, https://doi.org/10.7717/peerj.5871.

Erickson, R.A., Merkes, C.M., and Mize, E.L., 2019, Sampling designs for landscape-level eDNA monitoring programs: Integrated Environmental Assessment and Management, early view posted April 9, 2019, 12 p., https://doi.org/10.1002/ ieam.4155.

Hunter, M.E., Ferrante, J.A., Meigs-Friend, G., and Ulmer, A., 2019, Improving eDNA yield and inhibitor reduction through increased water volumes and multi-filter isolation techniques: Scientific Reports, v. 9, article no. 5259, https://doi.org/10.1038/s41598-019-40977-w.

Hunter, M.E., Hoban, S.M., Bruford, M.W., Segelbacher, G., and Bernatchez, L., 2018, Next-generation conservation genetics and biodiversity monitoring: Evolutionary Applications, v. 11, no. 7, p. 1029-1034, https://doi.org/10.1111/eva.12661.

Hunter, M.E., Meigs-Friend, G., Ferrante, J.A., Takoukam Kamla, A., Dorazio, R.M., Keith Diagne, L., Luna, F., Lanyon, J.M., and Reid, J.P., 2018, Surveys of environmental DNA (eDNA) - A new approach to estimate occurrence in vulnerable manatee populations: Endangered Species Research, v. 35, p. 101-111, https://doi.org/10.3354/esr00880.

\section{Using Genomics to Better Understand Habitat Use of the Atlantic 元}

BOEM managers use information on the ecology of the federally protected Atlantic sturgeon in coastal waters to understand the potential impacts from offshore energy development and fulfill obligations required under Federal laws. USGS scientists are developing genomics tools aimed at providing a cost-effective, high-resolution way to characterize the sturgeon population structure and demographics. Scientists have assembled and annotated the complete mitochondrial genome of both the Atlantic and Gulf sturgeon, allowing for detection of Atlantic and Gulf sturgeon eDNA in water. These techniques can allow large numbers of sturgeon to be identified to their river and distinct population segment of origin and facilitate accurate assessments of Atlantic sturgeon populations. These approaches are widely applicable to stock and impact assessments for a wide variety of imperiled or other species of management concern.

\section{Contacts}

Stephen Faulkner, USGS Leetown Science Center, faulkners@usgs.gov, (304) 724-4471

David Kazyak, USGS Leetown Science Center, dkazyak@usgs.gov, (304) 724-4577

\section{Publications}

Fritts, M.W., Grunwald, C., Wirgin, I., King, T.L., and Peterson, D.L., 2016, Status and genetic character of Atlantic sturgeon in the Satilla River, Georgia: Transactions of the American Fisheries Society, v. 145, no. 1, p. 69-82, https://doi.org/10.1080/000 28487.2015.1094131.

Wirgin, I., Breece, M.W., Fox, D.A., Maceda, L., Wark, K.W., and King, T., 2015, Origin of Atlantic sturgeon collected off the Delaware Coast during spring months: North American Journal of Fisheries Management, v. 35, no. 1, p. 20-30, https://doi.org/10.1080/02755947.2014.963751.

Wirgin, I., Maceda, L., Grunwald, C., and King, T.L., 2015, Population origin of Atlantic sturgeon Acipenser oxyrinchus by-catch in U.S. Atlantic coast fisheries: Journal of Fish Biology, v. 86, no. 4, p. 1251-1270, https://doi.org/10.1111/jfb.12631. 


\section{Additional Publications}

Baldigo, B.P., Sporn, L.A., George, S.D., and Ball, J.A., 2017, Efficacy of environmental DNA to detect and quantify brook trout populations in headwater streams of the Adirondack Mountains, New York: Transactions of the American Fisheries Society, v. 146, no. 1, p. 99-111, https://doi.org/10.1080/00028487.2016.1243578.

Chambert, T., Pilliod, D.S., Goldberg, C.S., Doi, H., and Takahara, T., 2018, An analytical framework for estimating aquatic species density from environmental DNA: Ecology and Evolution, v. 8, no. 6, p. 3468-3477, https://doi.org/10.1002/ ece3.3764.

Tillotson, M.D., Kelly, R.P., Duda, J.J., Hoy, M., Kralj, J., and Quinn, T.P., 2018, Concentrations of environmental DNA (eDNA) reflect spawning salmon abundance at fine spatial and temporal scales: Biological Conservation, v. 220, p. 1-11, https://doi.org/10.1016/j.biocon.2018.01.030.

\section{Fatality Estimation Tools}

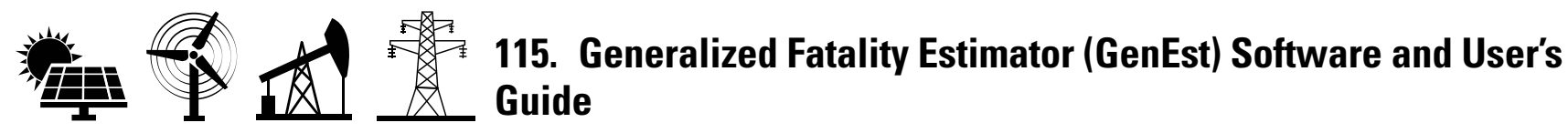

Numerous fatality estimators have been developed to estimate the number of bird and bat fatalities at wind energy facilities, but failure to meet their inherent assumptions can lead to different estimates of fatality. Working with statisticians who developed several of the estimators presently in use, the USGS, BCI, WEST, Inc., and Oregon State University have developed software that combines multiple approaches under a single generalized estimator (GenEst). GenEst allows the user to evaluate assumptions regarding input parameters and select the approach that best reflects the situation and data. The applicability of GenEst is not limited to wind power facilities. The tool is designed for use in any situation in which the objective is an estimate of a super population for which detection probability is unknown but can be estimated, such as solar facilities, oil spills, fisheries by-catch, and power-line or fence-line fatality rates.

\section{Contact}

Manuela M. Huso, USGS Forest and Rangeland Ecosystem Science Center, mhuso@usgs.gov, (541) 750-0948

\section{Publications}

Dalthorp, D., Madsen, L., Huso, M.M., Rabie, P., Wolpert, R., Studyvin, J., Simonis, J., and Mintz, J., 2018, GenEst statistical models-A generalized estimator of mortality: U.S. Geological Survey Techniques and Methods, book 7, chap. A2, 13 p., https://doi.org/10.3133/ tm7A2.

Dalthorp, D., Simonis, J., Madsen, L., Huso, M., Rabie, P., Mintz, J., Wolpert, R., Studyvin, J., and Korner-Nievergelt, F., 2018, GenEst - Generalized fatality estimator-R package: U.S. Geological survey software release, https://code.usgs.gov/ ecosystems/GenEst/releases.

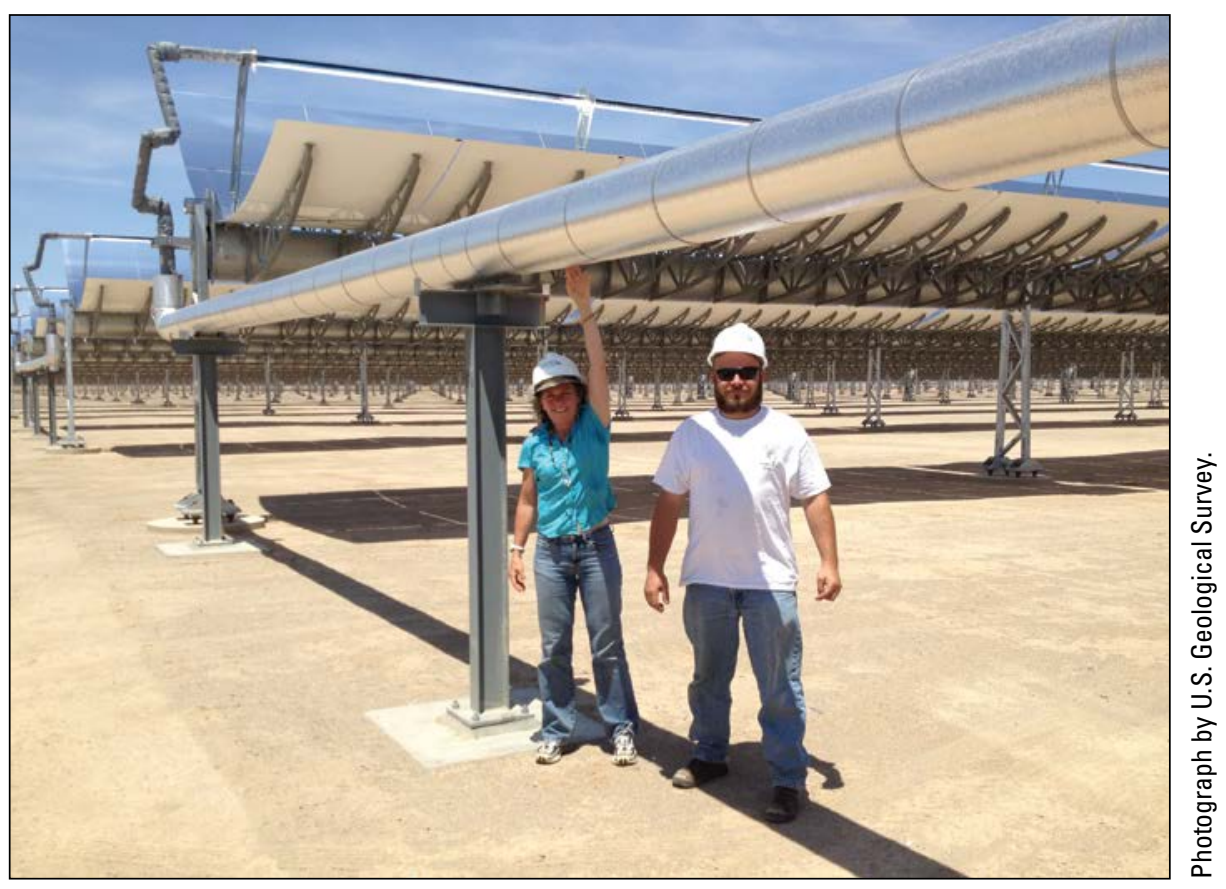

U.S. Geological Survey and U.S. Fish and Wildlife Service staff at a solar energy facility in southern California. A solar trough reflects the sun's rays towards a solar collector.

Simonis, J., Dalthorp, D., Huso, M., Mintz, J., Madsen, L., Rabie, P., and Studyvin, J., 2018, GenEst user guide—Software for a generalized estimator of mortality: U.S. Geological Survey Techniques and Methods, book 7, chap. C19, 72 p., https://doi.org/10.3133/tm7C19. 


\section{Developing a Model to Estimate Eagle-Carcass Density at Wind Energy Facilities}

Simple counts of bird carcasses found at wind energy facilities do not reflect actual fatalities because some carcasses are removed by scavengers or are overlooked by or fall within areas inaccessible to searchers. Models of how carcass density changes with distance from wind turbines are needed to account for eagle carcasses missed in unsearchable areas. Because bald and golden eagles are not found in adequate numbers at any single wind facility in the United States to allow for reliable estimation of eagle-carcass density, USGS researchers are using data from white-tailed eagles at the Smøla wind facility in Norway as surrogates. Eagle data from several sites in California will then be compared to the white-tailed eagle model to assure its applicability to large raptors in the United States. Results can be used by the USFWS in estimating post-construction eagle mortality.

\section{Contact}

Manuela M. Huso, USGS Forest and Rangeland Ecosystem Science Center, mhuso@usgs.gov, (541) 750-0948

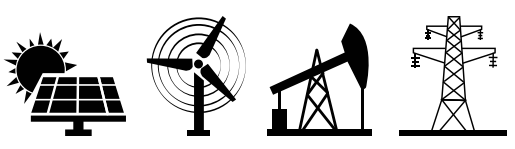

\section{Advances in Estimating Fatalities From Collisions With Energy Infrastructure}

Accurate estimates of bird and bat fatalities from collisions with energy infrastructure can be difficult because carcasses may not be detected or may be scavenged. These estimates, however, are critical to understanding the effects of collisions with energy infrastructure on species populations and devising effective methods to mitigate or minimize fatalities. Accurate estimation is complicated because carcasses may fall outside the search area, be removed by scavengers, or be missed by searchers during surveys. The USGS and USFWS are working to develop new tools and improve existing tools to estimate actual bird and bat fatalities based on carcass searches near energy infrastructure. Scientists are also investigating whether accurate and precise estimates of fatalities can be derived from carcass searches conducted at easily accessed areas, such as roads and pads beneath turbines.

\section{Contact}

Manuela M. Huso, USGS Forest and Rangeland Ecosystem Science Center, mhuso@usgs.gov, (541) 750-0948

\section{Publications}

Huso, M.M., Dalthorp, D.H., and Korner-Nievergelt, F., 2017, Statistical principles of post-construction fatality monitoring design, chap. 4 in Perrow, Martin, ed., Wildlife and wind farms, conflicts and solutions, Volume 2, Onshore-Monitoring and mitigation: Exeter, England, Pelagic, 227 p.

Huso, M., Dalthorp, D., Miller, T.J., and Bruns, D., 2016, Wind energy development-Methods to assess bird and bat fatality rates post-construction: Human-Wildlife Interactions, v. 10, no. 1, p. 62-70, https://doi.org/10.26077/36fe-0296.

Korner-Nievergelt, F., Behr, O., Brinkmann, R., Etterson, M.A., Huso, M.M.P., Dalthorp, D., Korner-Nievergelt, P., Roth, T., and Niermann, I., 2015, Mortality estimation from carcass searches using the R-package carcass-A tutorial: Wildlife Biology, v. 21, no. 1, p. 30-43, https://doi.org/10.2981/wlb.00094.

\section{Additional Publications}

Dalthorp, D., and Huso, M., 2015, A framework for decision points to trigger adaptive management actions in long-term incidental take permits: U.S. Geological Survey Open-File Report 2015-1227, 88 p., https://doi.org/10.3133/ofr20151227.

Dalthorp, D., Huso, M., and Dail, D., 2017, Evidence of absence (ver. 2.0) software user guide: U.S. Geological Survey Data Series 1055, 109 p., https://doi.org/10.3133/ds1055.

Huso, M., Dietsch, T., and Nicolai, C., 2016, Mortality monitoring design for utility-scale solar power facilities: U.S. Geological Survey Open-File Report 2016-1087, 44 p., https://doi.org/10.3133/ofr20161087.

Huso, M.M.P., and Dalthorp, D., 2014, Accounting for unsearched areas in estimating wind turbine-caused fatality: Journal of Wildlife Management, v. 78, no. 2, p. 347-358, https://doi.org/10.1002/jwmg.663.

Huso, M.M.P., Dalthorp, D., Dail, D., and Madsen, L., 2015, Estimating wind-turbine caused bird and bat fatality when zero carcasses are observed: Ecological Applications, v. 25, no. 5, p. 1213-1225, https://doi.org/10.1890/14-0764.1.

Johnson, D.H., Loss, S.R., Smallwood, K.S., and Erickson, W.P., 2016, Avian fatalities at wind energy facilities in North America-A comparison of recent approaches: Human-Wildlife Interactions, v. 10, no. 1, p. 7-18, https://doi.org/10.26077/ a4ec-ed37. 


\section{Terrestrial Habitat Restoration Following Energy Development}

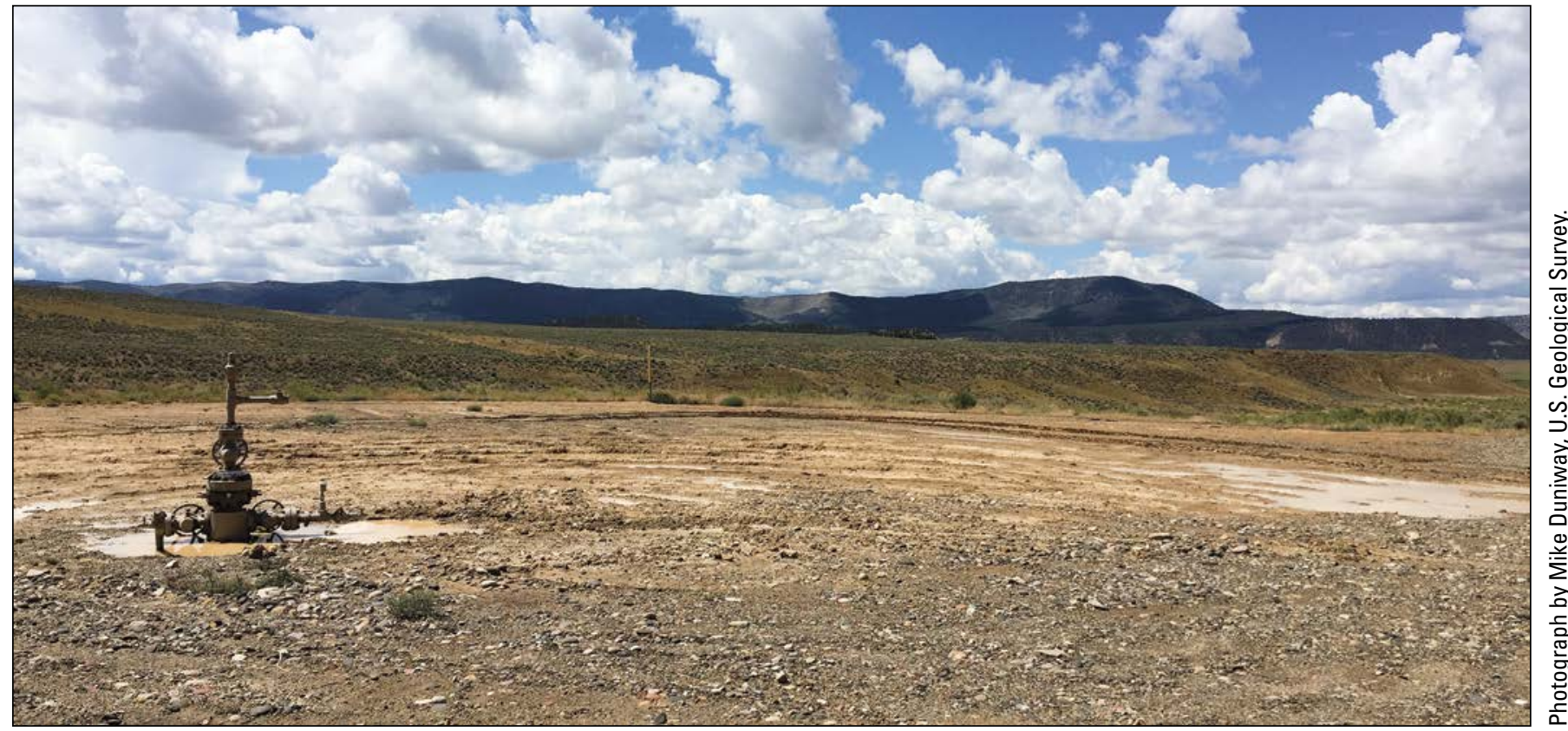

Oil pad near Vernal, Utah.

\section{Evaluating Reclamation Success Following Oil and Gas Development}

\section{USGS scientists are imple-} menting a range of scientific approaches to improve reclamation success following oil and gas development in Utah, Colorado, and New Mexico. In collaboration with the BLM, USFWS, and industry partners, reclamation experiments are testing seed mixes, soil and site modifications, soil stabilizers, and other novel approaches. USGS scientists are also assessing vegetation conditions and dust generation following oil and gas drilling activities across the region. Studies are incorporating satellite imagery, digital soil mapping, predictive ecological modeling, and field assessments to evaluate vegetation recovery and dust production following well pad abandonment. Results of monitoring and modeling horizontal aeolian sediment

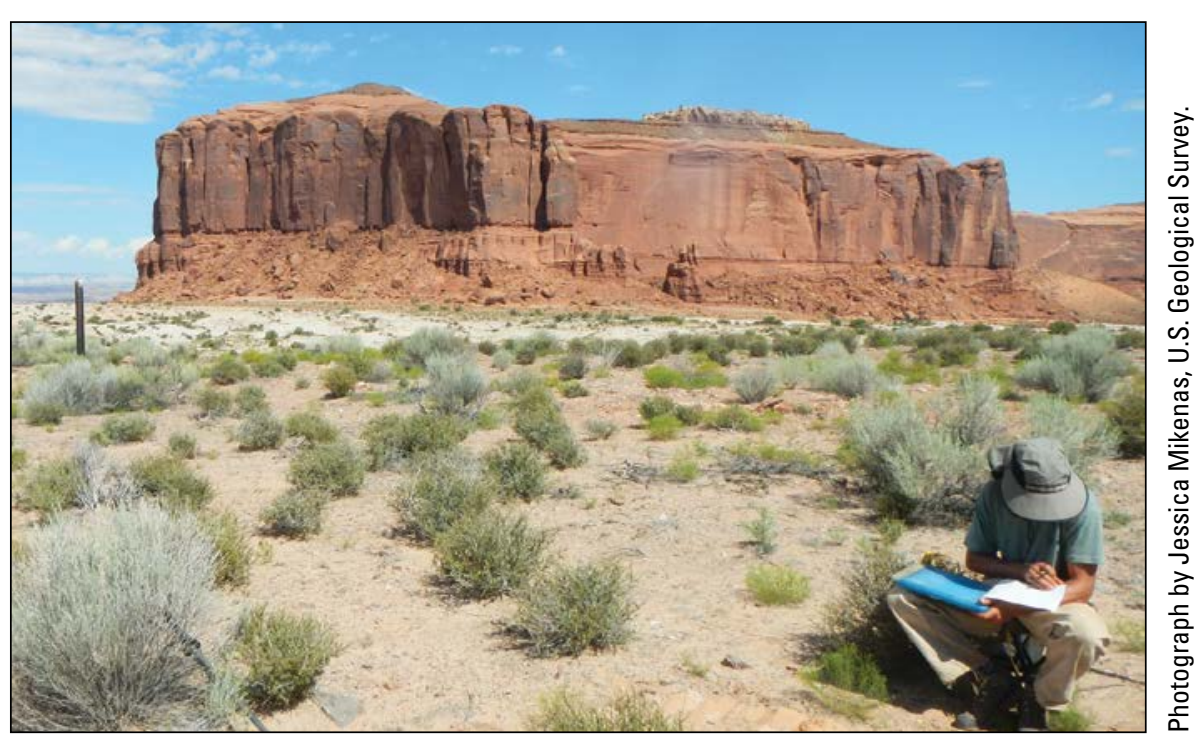

USGS soil scientist records vegetation data on a decommissioned well pad in Utah. movement, including dust, suggest that unpaved roads and plugged and abandoned well pads have more windblown sediment transport than surrounding rangelands, and results show variation between local soil types and vegetation communities where wells and roads are located. This suite of research activities can help resource managers make informed decisions for future well pad and infrastructure development.

\section{Contacts}

Michael Duniway, USGS Southwest Biological Science Center, mduniway@usgs.gov, (928) 556-7530

Miguel Villarreal, USGS Western Geographic Science Center, mvillarreal@usgs.gov, (650) 329-4261 


\section{Publications}

Duniway, M.C., Pfennigwerth, A.A., Fick, S.E., Nauman, T.W., Belnap, J., and Barger, N.N., 2019, Wind erosion and dust from US drylands-A review of causes, consequences, and solutions in a changing world: Ecosphere, v. 10, no. 3, e02650, 28 p., https://doi.org/10.1002/ecs2.2650.

Nauman, T.W., and Duniway, M.C., 2016, The automated reference toolset-A soil-geomorphic ecological potential matching algorithm: Soil Science Society of America Journal, v. 80, no. 5, p. 1317-1328, https://doi.org/10.2136/sssaj2016.05.0151.

Nauman, T.W., Duniway, M.C., Villarreal, M.L., and Poitras, T.B., 2017, Disturbance automated reference toolset (DART) Assessing patterns in ecological recovery from energy development on the Colorado Plateau: Science of the Total Environment, v. 584-585, April, p. 476-488, https://doi.org/10.1016/j.scitotenv.2017.01.034.

Nauman, T.W., Duniway, M.C., Webb, N.P., and Belnap, J., 2018, Elevated dust emissions on the Colorado Plateau, USAThe role of grazing, vehicle disturbance, and increasing aridity: Earth Surface Processes and Landforms, v. 43, no. 14, p. 2897-2914, https://doi.org/10.1002/esp.4457.

Poitras, T.B., Villarreal, M.L., Waller, E.K., Nauman, T.W., Miller, M.E., and Duniway, M.C., 2018, Identifying optimal remotely-sensed variables for ecosystem monitoring in Colorado Plateau drylands: Journal of Arid Environments, v. 153, p. 76-87, https://doi.org/10.1016/j.jaridenv.2017.12.008.

Waller, E.K., Villarreal, M.L., Poitras, T.B., Nauman, T.W., and Duniway, M.C., 2018, Landsat time series analysis of fractional plant cover changes on abandoned energy development sites: International Journal of Earth Observation and Geoinformation, v. 73, p. 407-419, https://doi.org/10.1016/j.jag.2018.07.008.

\section{Modeling Recovery of Sagebrush Ecosystems Using Remotely Sensed Vegetation Products}

Much of our current understanding of sagebrush restoration relies on results from localized studies that yield limited inferences for other locations and do not provide a clear understanding of spatial and temporal factors influencing recovery across the landscape. USGS and Colorado State University scientists developed a framework for modeling change in sagebrush cover on reclaimed well pads by using time-varying, remote-sensing products developed for the WLCI. This approach allows managers to predict recovery times of sagebrush across broad scales and assess the effects of factors such as weather and soils on outcomes. This information and resulting spatial data can help inform future development and planning processes.

\section{Contacts}

Cameron Aldridge, Colorado State University, in cooperation with USGS Fort Collins Science Center, aldridgec@usgs.gov, (970) 226-9433

Adrian Monroe, Colorado State University, in cooperation with USGS Fort Collins Science Center, amonroe@usgs.gov, (970) 226-9122

\section{Understanding Drought Stress in Sagebrush Ecosystems Associated With Energy Development}

The USGS, working with WLCI partners, is investigating the recovery of sagebrush ecosystems exposed to recent drought in the Upper Green River Basin, Wyoming. Scientists are using satellite data to understand decadal patterns of sagebrush productivity and detect monthly anomalies associated with drought-related sagebrush mortality to document the extent and severity of the disturbance. Scientists are also producing maps that highlight areas for plant community assessment. During 2018, scientists visited 10 sites affected by drought and 10 sites unaffected by drought to develop sampling protocols designed to discern patterns of vegetation anomalies at multiple scales. These protocols will be applied during the 2019 and 2020 growing seasons. This information can be used by resource managers to assess the recovery of sagebrush ecosystems exposed to multiple stressors such as drought and energy development.

\section{Contact}

Pat Anderson, USGS Fort Collins Science Center, andersonpj@usgs.gov, (970) 226-9488

\section{Publication}

Assal, T.J., 2018, Standardized precipitation evaporation index for the Upper Green River Basin (1896-2017): U.S. Geological Survey data release, https://doi.org/10.5066/P9VLM7Z6. 


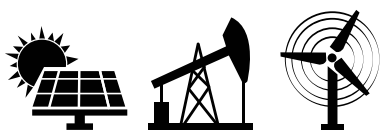

121. Method for Assessing the Ecological Integrity of Federal Lands in Nevada

Public lands in the Western United States are managed for diverse uses such as timber harvest, livestock grazing, energy development, and wildlife conservation. The USGS and partners proposed a method for assessing ecological integrity on multipleuse lands and applied the method to evaluate shrublands in Nevada. The approach yielded an assessment based on six indicators of ecosystem structure, function, and composition, including resource- and stressor-based indicators measured at multiple scales. Results may inform efforts to control invasive species and restore shrublands on Federal lands in Nevada.

\section{Contact}

Sarah K. Carter, USGS Fort Collins Science Center, skcarter@usgs.gov, (970) 226-9355

\section{Publication}

Carter, S.K., Fleishman, E., Leinwand, I.I.F., Flather, C.H., Carr, N.B., Fogarty, F.A., Leu, M., Noon, B.R., Wohlfeil, M.E., and Wood, D.J.A., 2019, Quantifying ecological integrity of terrestrial systems to inform management of multiple-use public lands in the United States: Environmental Management, v. 64 , no. 1, p. 1-19, https://doi.org/10.1007/s00267-01901163-w.

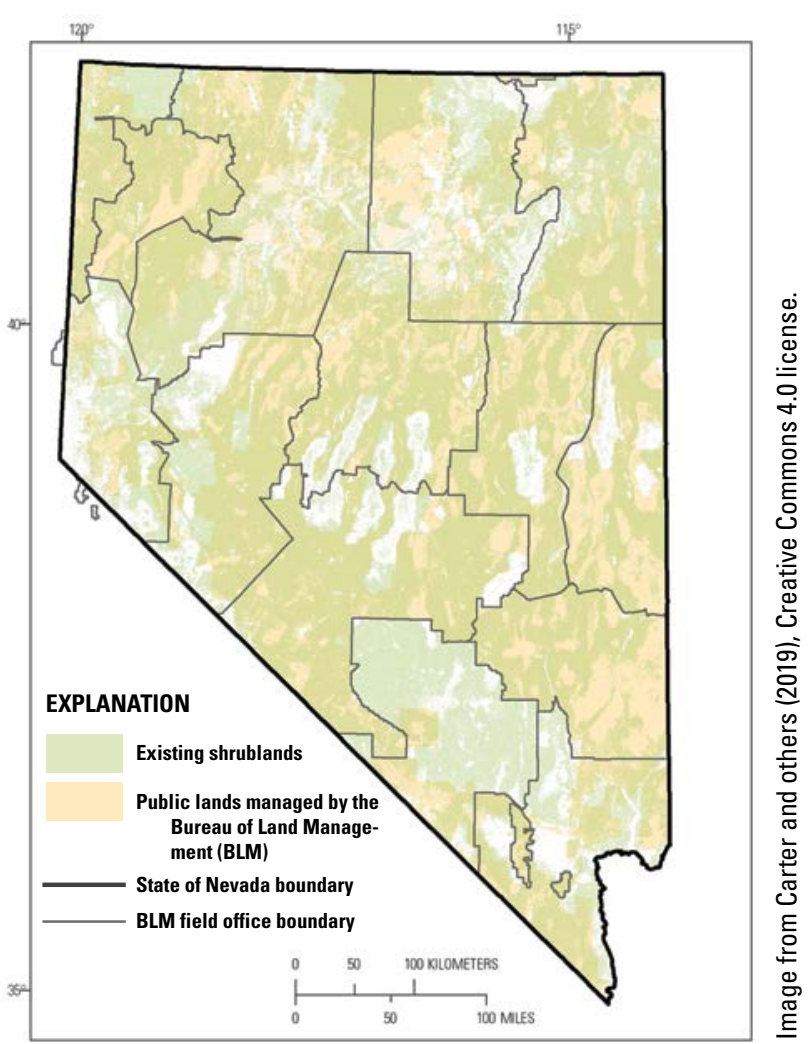

Current and historic shrublands and public lands managed by the BLM in Nevada.

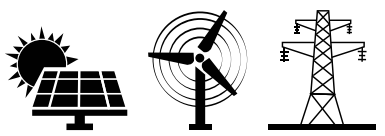

\section{Ecological Restoration and Native Plant Development in Hot Desert Systems}

Energy development across the Mojave and Sonoran Deserts has increased the demand for more effective restoration techniques and appropriate plant materials for seeding and planting disturbed areas. In collaboration with Rancho Santa Ana Botanical Garden, Texas State University, BLM, and USFWS, the USGS developed seed-transfer zones at a resolution appropriate to guide seed-collection activities across the Mojave Desert. A network of experimental gardens incorporates research on germination, establishment, and survivorship with landscape genetics and physiology on a variety of key native plant species.

\section{Contacts}

Lesley DeFalco, USGS Western Ecological Research Center, ldefalco@usgs.gov, (702) 564-4507

Todd Esque, USGS Western Ecological Research Center, tesque@usgs.gov, (702) 564-4506

\section{Publications}

Shryock, D.F., DeFalco, L.A., and Esque, T.C., 2018, Spatial decision-support tools to guide restoration and seed-sourcing in the Desert Southwest: Ecosphere, v. 9, no. 10, e02453, 19 p., https://doi.org/10.1002/ecs2.2453.

Shryock, D.F., Havrilla, C.A., DeFalco, L.A., Esque, T.C., Custer, N.A. and Wood, T.E., 2015, Landscape genomics of Sphaeralcea ambigua in the Mojave Desert-A multivariate, spatially-explicit approach to guide its use in ecological restoration: Conservation Genetics, v. 16, no. 6, p. 1303-1317, https://doi.org/10.1007/s10592-015-0741-1.

Shryock, D.F., Havrilla, C.A., DeFalco, L.A., Esque, T.C., Custer, N.A., and Wood, T.E., 2017, Landscape genetic approaches to guide native plant restoration in the Mojave Desert: Ecological Applications v. 27, no. 2, p. 429-445, https://doi.org/10.1002/ eap. 1447. 


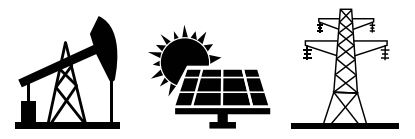

\section{Restoration Assessment and Monitoring Program for the Southwest}

The Restoration Assessment and Monitoring Program for the Southwest (RAMPS) seeks to assist Federal and State land management agencies in developing successful techniques for improving land conditions in dryland ecosystems of the Southwestern United States. Invasion by nonnative species, wildfire, drought, energy development, and other disturbances are increasing in extent and frequency, creating novel ecosystem conditions that can outpace the knowledge base of local land managers. These growing problems often cross administrative boundaries, requiring agencies to proactively work together. Considering these challenges, managers can benefit from collaborative, innovative, and dynamic approaches to sharing information. To meet this need, RAMPS has created a hub for science-based information and tools to help managers identify effective and resource-efficient strategies to successfully restore degraded areas.

\section{Contacts}

Molly McCormick, USGS Southwest Biological Science Center, mmccormick@usgs.gov, (928) 556-7305

Seth Munson, USGS Southwest Biological Science Center, smunson@usgs.gov, (928) 556-7301

\section{Publications}

Bradford, J.B., Betancourt, J.L., Butterfield, B.J., Munson, S.M., and Wood, T.E., 2018, Anticipatory natural resource management for a changing future: Frontiers in Ecology and the Environment, v. 16, no. 5, p. 295-303, https://doi.org/10.1002/fee.1806.

Butterfield, B.J., Copeland, S.M., Munson, S.M., Roybal, C.M., and Wood, T.E., 2017, Prestoration-Using species in restoration that will persist now and into the future: Restoration Ecology, v. 25, no. S2, p. S155-S163, https://doi.org/10.1111/ rec.12381.

Copeland, S.M., Munson, S.M., Bradford, J.B., and Butterfield, B.J., 2019, Influence of climate, post-treatment weather extremes, and soil factors on vegetation recovery after restoration treatments in the southwestern US: Applied Vegetation Science, v. 22, no. 1, p. 85-95, https://doi.org/10.1111/avsc.12414.

Copeland, S.M., Munson, S.M., Bradford, J.B., Butterfield, B.J., and Gunnell, K.L., 2019, Long-term plant community trajectories suggest divergent responses of native and non-native perennials and annuals to vegetation removal and seeding treatments: Restoration Ecology, v. 27, no. 4, p. 821-31, https://doi.org/10.1111/rec.12928.

Copeland, S.M., Munson, S.M., Pilliod, D.S., Welty, J.L., Bradford, J.B., and Butterfield, B. J., 2018, Long-term trends in restoration and associated land treatments in the southwestern United States: Restoration Ecology, v. 26, no. 2, p. 311-322, https://doi.org/10.1111/rec.12574.

Doherty, K.D., Butterfield, B.J., and Wood, T.E., 2017, Matching seed to site by climate similarity—Techniques to prioritize plant materials development and use in restoration: Ecological Applications, v. 27, no. 3, p. 1010-1023, https://doi.org/10.1002/eap.1505.

Wiechman, L.A., Pyke, D.A., Crist, M.R., Munson, S.M., Brooks, M.L., Chambers, J.C., Rowland, M.M., Kachergis, E.J., and Davidson, Z., 2019, Adaptive management and monitoring, chap. 2 of Crist, M.R., Chambers, J.C., Phillips, S.L., Prentice, K.L., and Wiechman, L.A., eds., Science framework for conservation and restoration of the sagebrush biome-Linking the Department of the Interior's Integrated Rangeland Fire Management Strategy to long-term strategic conservation actions, part 2-Management applications: Fort Collins, Colo., U.S. Department of Agriculture, U.S. Forest Service, General Technical Report RMRS-GTR-389, 237 p., https://doi.org/10.2737/RMRS-GTR-389.

Winkler, D.E., Backer, D.M., Belnap, J., Bradford, J.B., Butterfield, B.J., Copeland, S.M., Duniway, M.C., Faist, A.M., Fick, S.E., Jensen, S.L., Kramer, A.T., Mann, R., Massatti, R.T., McCormick, M.L., Munson, S.M., Olwell, P., Parr, S.D., Pfennigwerth, A.A., Pilmanis, A.M., Richardson, B.A., Samuel, E., See, K., Young, K., and Reed, S.C., 2018, Beyond traditional ecological restoration on the Colorado Plateau: Restoration Ecology, v. 26, no. 6, p. 1055-1060, https://doi.org/10.1111/rec.12876. 


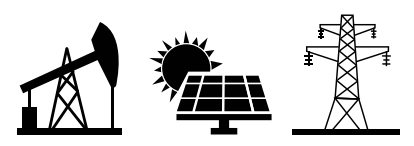

\section{Distributed Field Trial Network for Dryland Restoration}

of land in the Southwest. Researchers at the USGS, Northern Arizona University, University of Arizona, New Mexico State University, and University California, Riverside, are working with land managers from the BLM, NPS, USFWS, Navajo Nation National Heritage Program, Diablo Trust Ranches, Babbit Ranches, and The Nature Conservancy to develop RestoreNet, a network of restoration field trial sites covering the Colorado Plateau and Sonoran, Chihuahuan, and Mojave Deserts. The goals of RestoreNet are to provide information to land managers on methods to improve restoration outcomes, assess the ecosystem services (for example, forage, erosion control, soil fertility, pollination) provided by restored species and communities, complement existing knowledge on development of native plant materials, and minimize costs of developing new infrastructure. The RestoreNet network of field sites can help test novel restoration treatments and serve as demonstration sites for land managers and practitioners.

\section{Contacts}

Molly McCormick, USGS Southwest Biological Science Center, mmccormick@usgs.gov, (928) 556-7305

Seth Munson, USGS Southwest Biological Science Center, smunson@usgs.gov, (928) 556-7301

\section{Additional Resource}

U.S. Geological Survey, 2019, RestoreNet—Distributed field trial network for dryland restoration: U.S. Geological Survey web page, https://www.usgs.gov/centers/sbsc/ science/restorenet-distributed-field-trial-network-drylandrestoration.

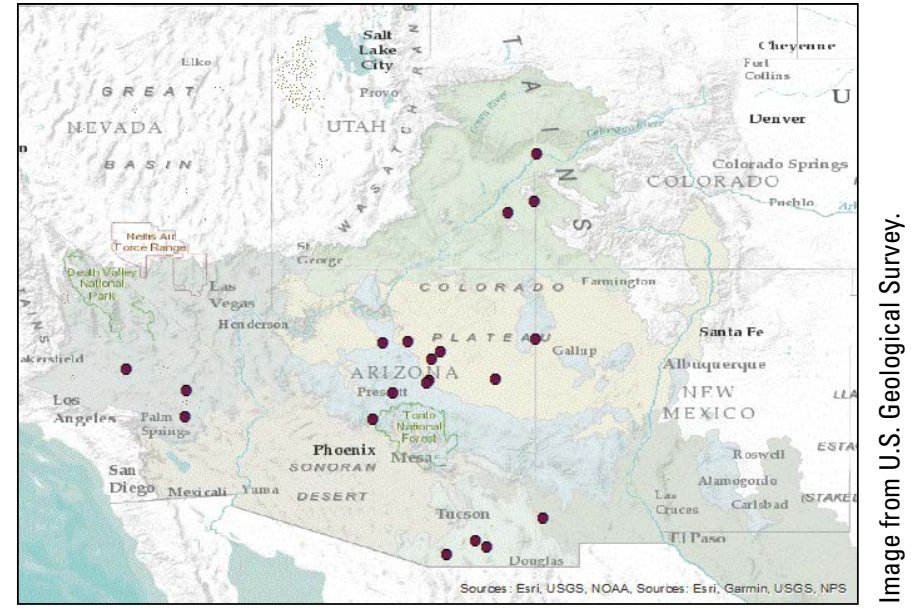

RestoreNet has sites located across ecosystems of the Southwestern United States.

\section{Aquatic Habitat Restoration and Recovery Following Dam Removal}

\section{细} 125. Reintroduction of Anadromous Salmonids to Reservoirs Above Hydroelectric Dams

The reintroduction of extirpated salmonids to historically occupied areas is becoming increasingly common as a conservation and recovery strategy. USGS scientists are evaluating the feasibility of reintroducing native salmonids to reservoirs and tributaries upstream of hydropower dams in northern California, Oregon, and Washington. Reservoirs serve both as functional migration corridors and profitable juvenile-rearing habitats despite hosting abundant predator populations. Scientists evaluated consumption demand and seasonal food availability as well as potential predation mortality to juvenile anadromous salmonids. In a new study for the Yale Lake and Lake Merwin hydropower projects in Washington State, scientists used a combination of field data and existing information to address key objectives related to the reintroduction of salmonids and to inform decisions about fish passage. These approaches can assist fisheries managers and power operators by identifying options for design and operations of hydropower facilities that could balance power demand with increased fish production.

\section{Contact}

David A. Beauchamp, USGS Western Fisheries Research Center, fadave@usgs.gov, (206) 526-6596

\section{Publications}

Adams, N.S., Liedtke, T.L., Plumb, J.M., Weiland, L.K., Hansen, A.C., and Evans, S.D., 2018, Emigration and transportation stress of juvenile Chinook salmon relative to their reintroduction upriver of Shasta Dam, California, 2017-18: U.S. Geological Survey Open-File Report 2018-1144, 60 p., https://doi.org/10.3133/ofr20181144.

Al-Chokhachy, R., Clark, C.L., Sorel, M.H., and Beauchamp, D.A., 2018, Development of new information to inform fish passage decisions at the Yale and Merwin hydro projects on the Lewis River, Washington-Final report, 2018: U.S. Geological Survey Open-File Report 2018-1190, 206 p., https://doi.org/10.3133/ofr20181190.

Haskell, C.A., Beauchamp, D.A., and Bollens, S.M., 2017, Linking functional response and bioenergetics to estimate juvenile salmon growth in a reservoir food web: PLOS ONE, v. 12, no. 10, e0185933, 21 p., https://doi.org/10.1371/journal. pone. 0185933 . 


\section{Ecological Effects of Dam Removal}

After nearly a century of power production, two large hydroelectric dams on the Elwha River in Washington State were removed during 2011-14 to restore the river ecosystem and recover economically and culturally important salmon populations. About two-thirds of the 21 million cubic meters of sediment — enough to fill nearly 2 million dump trucks - contained behind the dams was released downstream, restoring natural processes and initiating important changes to the river, estuarine, and marine ecosystems. A multidisciplinary team of scientists from the Lower Elwha Klallam Tribe, academia, NGOs, Federal and State agencies, and the USGS collected data before, during, and after dam removal to understand the outcomes of the project on the Elwha River ecosystem. This information can be used to inform future large-scale dam removal projects.

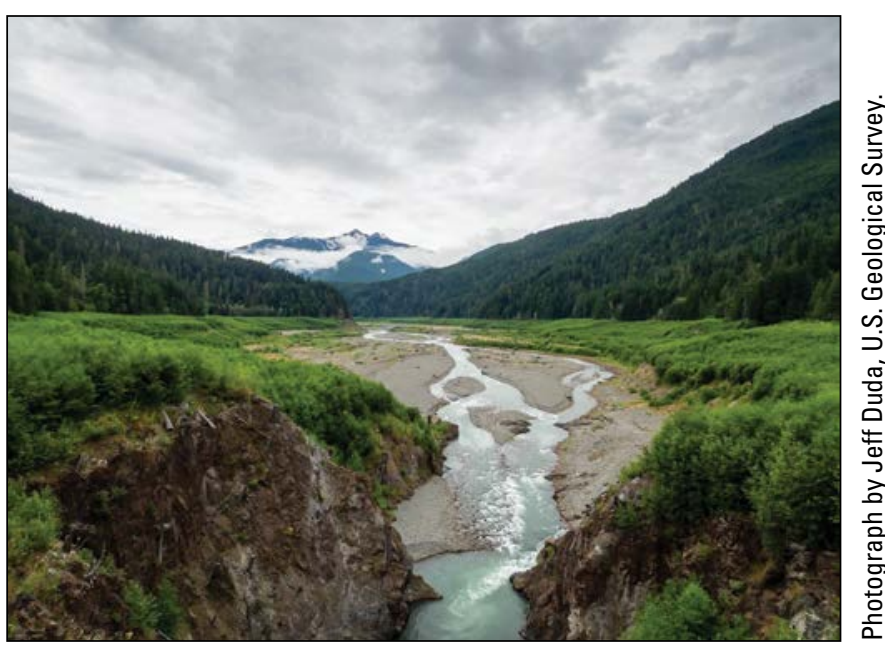

The Elwha River, Washington, following dam removal.

Contact

Jeff Duda, USGS Western Fisheries Research Center, jduda@usgs.gov, (206) 526-2532

\section{Publications}

Bellmore, J.R., Pess, G.R., Duda, J.J., O’Connor, J.E., East, A.E., Foley, M.M., Wilcox, A.C., Major, J.J., Shafroth, P.B., Morley, S.A., Magirl, C.S., Anderson, C.W., Evans. J.E., Torgersen, C.E., and Craig, L.S., 2019, Conceptualizing ecological responses to dam removal-If you remove it, what's to come?: BioScience, v. 69, no. 1, p. 26-39, https://doi.org/10.1093/biosci/biy152.

Duda, J.J., Beirne, M.M., Warrick, J.A., and Magirl, C.S., 2018, Science partnership between U.S. Geological Survey and the Lower Elwha Klallam Tribe-Understanding the Elwha River Dam Removal Project: U.S. Geological Survey Fact Sheet 2018-3025, 4 p., https://doi.org/10.3133/fs20183025.

East, A.E., Logan, J.B., Mastin, M.C., Ritchie, A.C., Bountry, J.A., Magirl, C.S., and Sankey, J.B., 2018, Geomorphic evolution of a gravel-bed river under sediment-starved versus sediment-rich conditions-River response to the world's largest dam removal: Journal of Geophysical Research—Earth Surface, v. 123, no. 12, p. 3338-3369, https://doi.org/10.1029/2018JF004703.

Foley, M.M., Warrick, J.A., Ritchie, A., Stevens, A.W., Shafroth, P.B., Duda, J.J., Beirne, M.M., Paradis, R., Gelfenbaum, G., McCoy, R., and Cubley, E.S., 2017, Coastal habitat and biological community response to dam removal on the Elwha River: Ecological Monographs, v. 87, no. 4, p. 552-577, https://doi.org/10.1002/ecm.1268.

McCaffery, R., McLaughlin, J., Sager-Fradkin, K., and Jenkins, K.J., 2018, Terrestrial fauna are agents and endpoints in ecosystem restoration following dam removal: Ecological Restoration, v. 36, no. 2, p. 97-107, https://doi.org/10.3368/ er.36.2.97.

\section{(IX 127. A Multiscale Approach to Balance Tradeoffs Among Dam Infrastructure, River Restoration, and Cost}

Aging infrastructure and growing interests in river restoration have led to a substantial rise in dam removals in the United States; however, the decision to remove a dam involves many complex tradeoffs. The USGS and partners assessed the tradeoffs and synergies involved with coordinated dam removal at three spatial scales in New England. They found that increasing the spatial scale affected by dam decisions improves tradeoffs among ecosystem services, river safety, and cost, but the benefits of large-scale river restoration vary dramatically by location. The model may help facilitate future dam-decision negotiations by identifying appropriate scales, locations, and criteria that satisfy multilateral funding, policy, and stakeholder goals.

\section{Contact}

Joseph Zydlewski, USGS Maine Cooperative Fish and Wildlife Research Unit, josephz@maine.edu, (207) 581-2853 


\section{Publications}

Maynard, G.A., Izzo, L.K., and Zydlewski, J.D., 2018, Movement and mortality of Atlantic salmon kelts (Salmo salar) released into the Penobscot River, Maine: Fishery Bulletin, v. 116, nos. 3-4, p. 281-290, https://doi.org/10.7755/FB.116.3-4.6.

Roy, S.G., Uchida, E., de Souza, S.P., Blachly, B., Fox, E., Gardner, K., Gold, A.J., Jansujwicz, J., Klein, S., McGreavy, B., Mo, W., Smith, S.M.C., Vogler, E., Wilson, K., Zydlewski, J., and Hart, D., 2018, A multiscale approach to balance tradeoffs among dam infrastructure, river restoration, and cost: Proceedings of the National Academy of Sciences, v. 115, no. 47, p. 12069-12074, https://doi.org/10.1073/pnas.1807437115.

Watson, J.M., Coghlan, S.M., Zydlewski, J., Hayes, D.B., and Kiraly, I.A., 2018, Dam removal and fish passage improvement influence fish assemblages in the Penobscot River, Maine: Transactions of the American Fisheries Society, v. 147, no. 3 , p. 525-540, https://doi.org/10.1002/tafs.10053.

\section{Additional Publications}

Galbraith, H.S., Blakeslee, C.J., Cole, J.C., and Silldorff, E.L., 2018, Freshwater mussel survey for the Columbia Dam removal, Paulins Kill, New Jersey: U.S. Geological Survey Open-File Report 2018-1074, 7 p., https://doi.org/10.3133/ofr20181074.

Hardiman, J.M., Breyta, R.B., Haskell, C.A., Ostberg, C.O., Hatten, J.R., and Connolly, P.J., 2017, Risk assessment for the reintroduction of anadromous salmonids upstream of Chief Joseph and Grand Coulee Dams, northeastern Washington: U.S. Geological Survey Open-File Report 2017-1113, 87 p., https://doi.org/10.3133/ofr20171113.

Jezorek, I.G., and Hardiman, J.M., 2017, Juvenile salmonid monitoring in the White Salmon River, Washington, post-Condit Dam removal, 2016: U.S. Geological Survey Open-File Report 2017-1070, 34 p., https://doi.org/10.3133/ofr20171070.

Jezorek, I.G., and Hardiman, J.M., 2018, Juvenile salmonid monitoring following removal of Condit Dam in the White Salmon River Watershed, Washington, 2018: U.S. Geological Survey Open-File Report 2018-1106, 31 p., https://doi.org/10.3133/ ofr20181106. 


\section{References Cited}

Adams, M.J., Miller, D.A.W., Muths, E., Corn, P.S., Grant, E.H.C., Bailey, L.L., Fellers, G.M., Fisher, R.N., Sadinski, W.J., Waddle, H., and Walls, S.C., 2013, Trends in amphibian occupancy in the United States: PLOS ONE, v. 8, no. 5, e64347, 5 p., accessed August 28, 2019, at https://doi.org/10.1371/journal.pone.0064347.

American Wind Energy Association, 2019, U.S. wind industry first quarter 2019 market report, AWEA public version: Washington, D.C., American Wind Energy Association Data Services, accessed July 22, 2019, at https://www.awea.org/ resources/publications-and-reports/market-reports/2019-u-s-wind-industry-market-reports/q12019_marketreport.

Amundson, C.L., Flint, P.L., Stehn, R.A., Platte, R.M., Wilson, H.M., Larned, W.W., and Fischer, J.B., 2019, Spatio-temporal population change of Arctic-breeding waterbirds on the Arctic Coastal Plain of Alaska: Avian Conservation and Ecology, v. 14, no. 1, article no. 18, 19 p., accessed July 22, 2019, at https://doi.org/10.5751/ACE-01383-140118.

Boyles, J.G., Cryan, P.M., McCracken, G.F., and Kunz, T.H., 2011, Economic importance of bats in agriculture: Science, v. 332, no. 6,025, p. 41-42, accessed September 5, 2018, at https://doi.org/10.1126/science.1201366.

Carter, S.K., Fleishman, E., Leinwand, I.I.F., Flather, C.H., Carr, N.B., Fogarty, F.A., Leu, M., Noon, B.R., Wohlfeil, M.E., and Wood, D.J.A., 2019, Quantifying ecological integrity of terrestrial systems to inform management of multipleuse public lands in the United States: Environmental Management, v. 64, no. 1, p. 1-19, accessed July 22, 2019, at https://doi.org/10.1007/s00267-019-01163-w.

Cryan, P.M., Gorresen, P.M., Hein, C.D., Schirmacher, M.R., Diehl, R.H., Huso, M.M., Hayman, D.T.S., Fricker, P.D., Bonaccorso, F.J., Johnson, D.H., Heist, K., and Dalton, D.C., 2014, Behavior of bats at wind turbines: Proceedings of the National Academy of Sciences, v. 111, no. 42, p. 15126-15131, accessed August 28, 2019, https://doi.org/10.1073/ pnas. 1406672111.

Great Lakes Fishery Commission, 2018, Sea lamprey-What is at risk? Great Lakes Fishery Commission website, accessed August 9, 2018, at http://www.glfc.org/what-is-at-risk.php.

Halstead, B.J., Kleeman, P.M., Duarte, A., Rose, J.P., Urquhart, K., Mellison, C., Guadalupe, K., Cota, M., Van Horne, R., Killion, A., and Ruehling, K., 2019, Monitoring protocol development and assessment for narrowly endemic toads in Nevada, 2018: U.S. Geological Survey Open-File Report 2019-1067, 28 p., accessed July 22, 2019, at https://doi.org/10.3133/ ofr20191067.

Hellerstein, D., Hitaj, C., Smith, D., and Davis, A., 2017, Land use, land cover, and pollinator health-A review and trend analysis: U.S. Department of Agriculture, Economic Research Service, report no. 232, 41 p., accessed July 22, 2019, at https://www.ers.usda.gov/webdocs/publications/84035/err-232.pdf?v=42908.

Hoen, B.D., Diffendorfer, J.E., Rand, J.T., Kramer, L.A., Garrity, C.P., and Hunt, H.E., 2019, United States Wind Turbine Database [USWTDB]: U.S. Geological Survey, American Wind Energy Association, and Lawrence Berkeley National Laboratory data release, USWTDB v. 2.1, July 15, accessed August 14, 2019, at https://eerscmap.usgs.gov/uswtdb.

Hüppop, O., Ciach, M., Diehl, R.H., Reynolds, D.R., Stepanian, P.M., and Menz, M.H.M., 2019, Perspectives and challenges for the use of radar in biological conservation: Ecography, v. 42, no. 5, p. 912-930, accessed July 22, 2019, at https://doi.org/10.1111/ecog.04063.

Lovich, J.E., Ennen, J.R., Agha, M., and Gibbons, J.W., 2018, Where have all the turtles gone, and why does it matter?: BioScience, v. 68, no. 10, p. 771-781, accessed July 11, 2019, at https://doi.org/10.1093/biosci/biy095.

Mathews, S.R., Coates, P.S., Prochazka, B.G., Ricca, M.A., Meyerpeter, M.B., Espinosa, S.P., Lisius, S., Gardner, S.C., and Delehanty, D.J., 2018, An integrated population model for greater sage-grouse (Centrocercus urophasianus) in the Bi-State Distinct Population Segment, California and Nevada, 2003-17: U.S. Geological Survey Open-File Report 2018-1177, 89 p., accessed July 22, 2019, at https://doi.org/10.3133/ofr20181177.

Millsap, B.A., Bjerre, E.R., Otto, M.C., Zimmerman, G.S., and Zimpfer, N.L., 2016, Bald and golden eagles—Population demographics and estimation of sustainable take in the United States, 2016 update: Washington, D.C., U.S. Fish and Wildlife Service, Division of Migratory Bird Management, 101 p.

Muthersbaugh, M.S., Ford, W.M., Powers, K.E., and Silvis, A., 2019, Activity patterns of bats during the fall and spring along ridgelines in the central Appalachians: Journal of Fish and Wildlife Management, v. 10, no. 1, p. 180-195, accessed July 22, 2019, at https://doi.org/10.3996/082018-JFWM-072. 
Pearse, A.T., Rabbe, M., Juliusson, L.M., Bidwell, M.T., Craig-Moore, L., Brandt, D.A., and Harrell, W., 2018, Delineating and identifying long-term changes in the whooping crane (Grus americana) migration corridor: PLOS ONE v. 13, no. 2, e0192737, 15 p., accessed July 22, 2019, at https://doi.org/10.1371/journal.pone.0192737.

Preston, T.M., Anderson, C.W., Thamke, J.N., Hossack, B.R., Skalak, K.J., and Cozzarelli, I.M., 2019, Predicting attenuation of salinized surface- and groundwater-resources from legacy energy development in the Prairie Pothole Region: Science of the Total Environment, v. 690, p. 522-533, accessed July 22, 2019, at https://doi.org/10.1016/j.scitotenv.2019.06.428.

Reese, G.C., Carter, S.K., Lund, C., and Walterscheid, S., 2019, Evaluating and using existing models to map probable suitable habitat for rare plants to inform management of multiple-use public lands in the California desert: PLOS ONE, v. 14, no. 4, e0214099, 26 p., accessed July 22, 2019, at https://doi.org/10.1371/journal.pone.0214099.

Rodhouse, T.J., Rodriguez, R.M., Banner, K.M., Ormsbee, P.C., and Irvine, K.M., 2019, Evidence of region-wide bat population decline from long-term monitoring and Bayesian occupancy models with empirically informed priors: Ecology and Evolution, early view, posted September 11, 2019, 11 p., accessed September 12, 2019, at https://doi.org/10.1002/ece3.5612.

Shaffer, J.A., and Buhl, D.A., 2015, Effects of wind-energy facilities on breeding grassland bird distributions: Conservation Biology, v. 30, no. 1, p. 59-71, accessed July 22, 2019, at https://doi.org/10.1111/cobi.12569.

Soeder, D.J., and Kent, D.B., 2018, When oil and water mix-Understanding the environmental impacts of shale development: GSA Today, v. 28, no. 9, p. 4-10, accessed July 22, 2019, at https://doi.org/10.1130/GSATG361A.1.

Solar Energy Industries Association, 2019, Major solar projects list: Solar Energy Industries Association web page, accessed September 16, 2019, at https://www.seia.org/research-resources/major-solar-projects-list.

Tracey, J.A., Madden, M.C., Bloom, P.H., Katzner, T.E., and Fisher, R.N., 2018, Golden eagle (Aquila chrysaetos) habitat selection as a function of land use and terrain, San Diego County, California: U.S. Geological Survey Open-File Report 2018-1067, 13 p., accessed July 22, 2019, at https://doi.org/10.3133/ofr20181067.

Watson, R.T., Kolar, P.S., Ferrer, M., Nygård, T., Johnston, N., Hunt, W.G., Smit-Robinson, H.A., Farmer, C.J., Huso, M., and Katzner, T., 2018, Raptor interactions with wind energy-Case studies from around the world: Journal of Raptor Research, v. 52, no. 1, p. 1-18, accessed August 12, 2019, at https://doi.org/10.3356/JRR-16-100.1.

Wyckoff, T.B., Sawyer, H., Albeke, S.E., Garman, S.L., and Kauffman, M.J., 2018, Evaluating the influence of energy and residential development on the migratory behavior of mule deer: Ecosphere, v. 9, no. 2, e02113, 13 p., accessed August 19, 2019, at https://doi.org/10.1002/ecs2.2113. 


\section{List of Species}

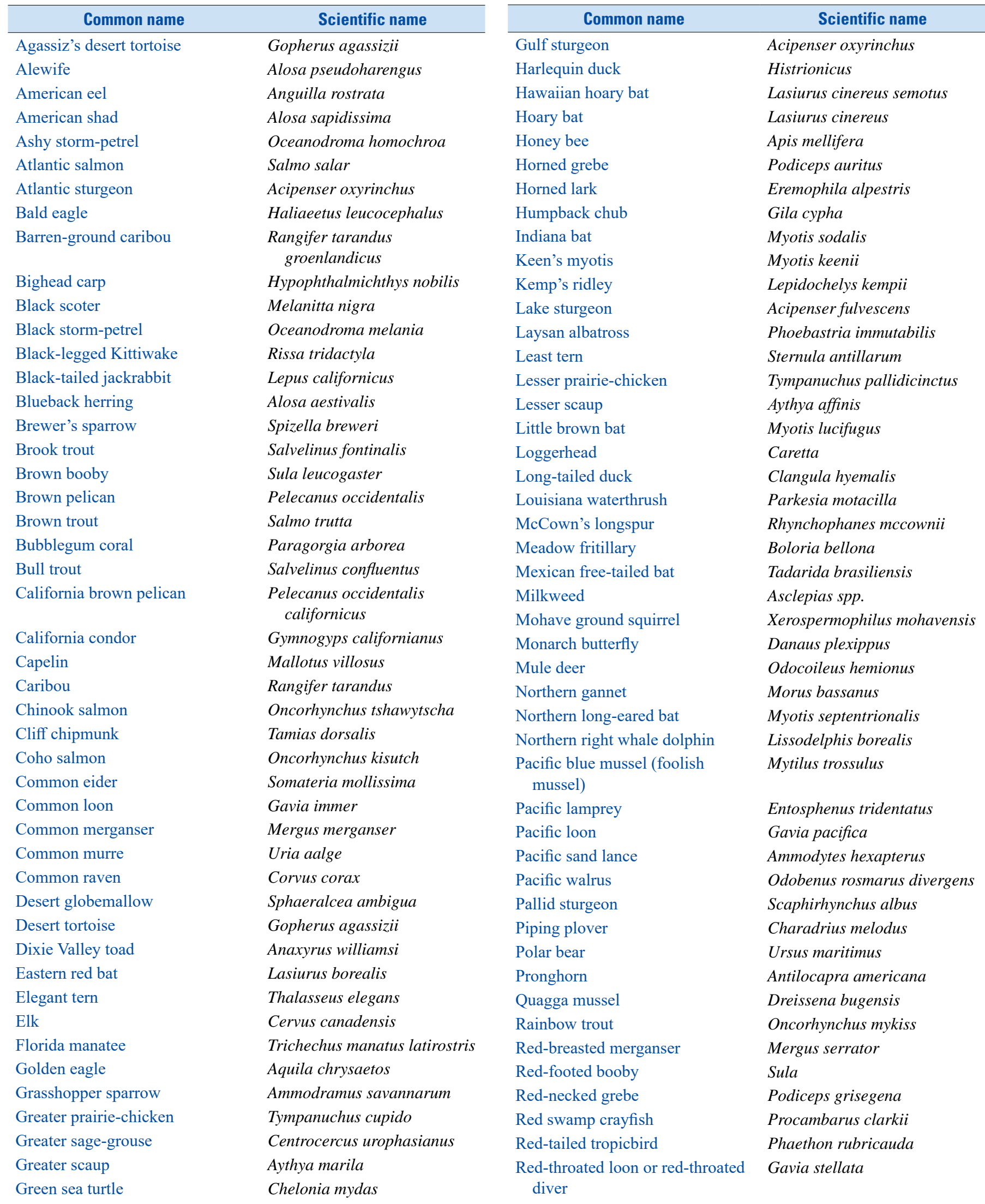




\section{List of Species-Continued}

\begin{tabular}{ll}
\hline \multicolumn{1}{c}{ Common name } & \multicolumn{1}{c}{ Scientific name } \\
\hline Roseate tern & Sterna dougallii \\
Round goby & Neogobius melanostomus \\
Rusty crayfish & Orconectes rusticus \\
Rusty patched bumble bee & Bombus affinis \\
Sage thrasher & Oreoscoptes montanus \\
Sagebrush sparrow & Artemisiospiza nevadensis \\
Sandhill crane & Grus canadensis \\
Scripps's murrelet & Synthliboramphus scrippsi \\
Sea lamprey & Petromyzon marinus \\
Sea otter & Enhydra lutris \\
Sharp-tailed grouse & Tympanuchus phasianellus \\
Silver carp & Hypophthalmichthys molitrix \\
Sockeye salmon & Oncorhynchus nerka \\
Spectacled eider & Somateria fischeri \\
Steelhead & Oncorhynchus mykiss \\
Surf scoter & M elanitta perspicillata \\
Swainson's hawk & Buteo swainsoni \\
Swamp milkweed & Asclepias incarnata \\
Townsend's big-eared bat & Corynorhinus townsendii \\
Wedge-tailed shearwater & Puffinus pacificus \\
Western toad & Anaxyrus boreas \\
White-tailed eagle & Haliaeetus albicilla \\
White-tailed jackrabbit & Lepus townsendii \\
White-winged scoter & M elanitta deglandi \\
Whooping crane & Grus americana \\
Woolly paperflower & Psilostrophe tagetina \\
Yellow-billed loon & Gavia adamsii \\
Zebra mussel & Dreissena polymorpha \\
\hline
\end{tabular}




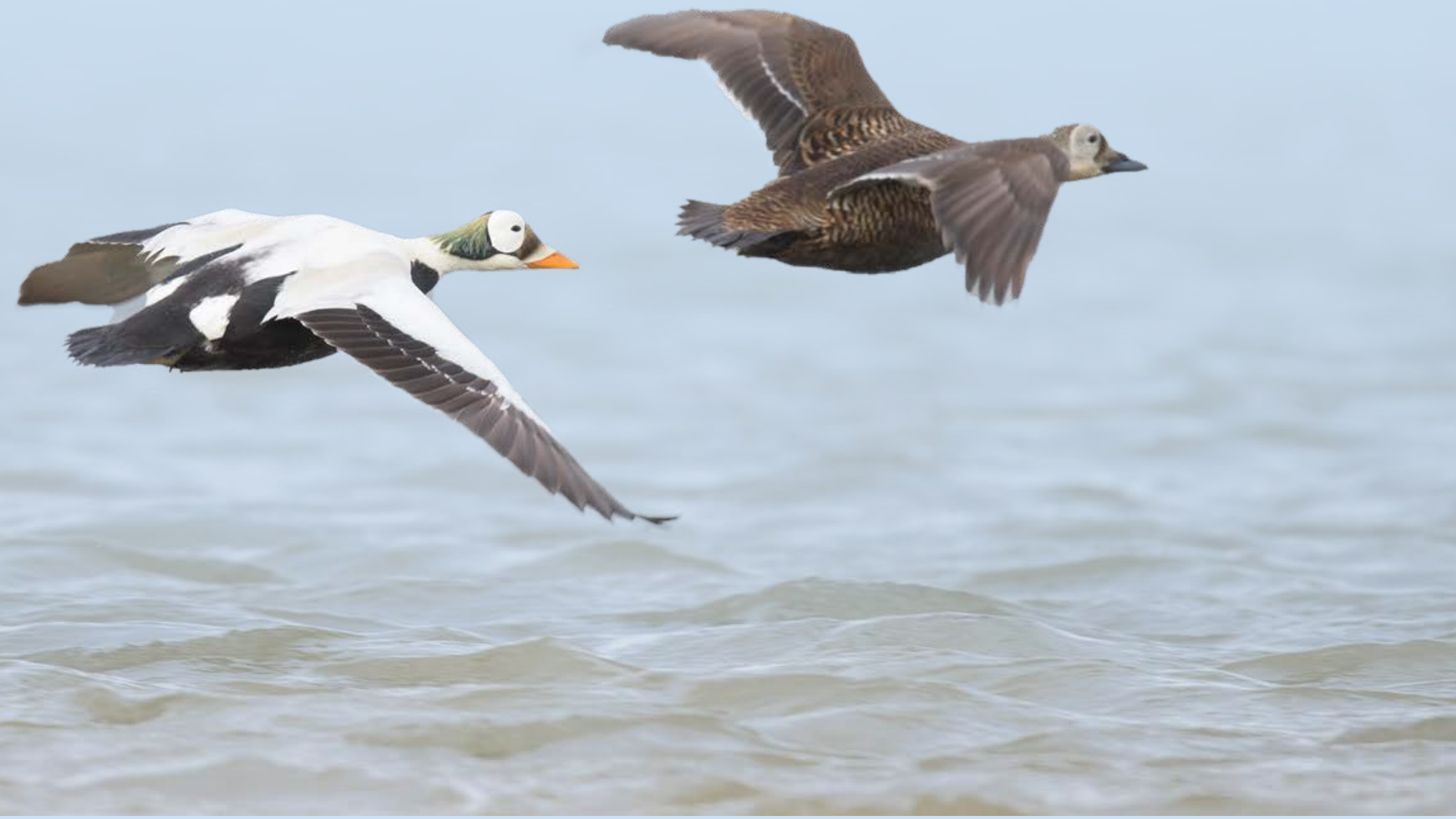

Pair of spectacled eiders flying near the Colville River, Alaska. Photograph by Ryan Askren, U.S. Geological Survey.

For additional information regarding this publication, please contact: Mona Khalilmkhali@usgs.gov

Or visit the USGS Energy and Wildlife Program https://www.usgs.gov/ecosystems/energy-wildlife

Prepared by the USGS Science Publishing Network Reston and Rolla Publishing Service Centers

Edited by Rachel Gidley

Layout by Suzanne C. Roberts 


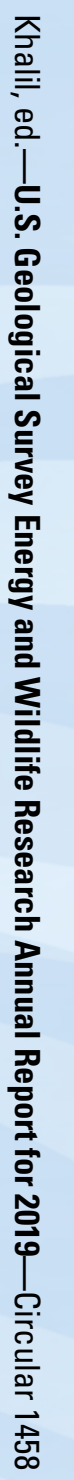

